KARINNE ANSILIERO ANGELIN

\title{
DANO INJUSTO COMO PRESSUPOSTO DO DEVER DE INDENIZAR
}

\author{
Dissertação de mestrado \\ Orientador: Professor Associado José Fernando Simão
}

FACULDADE DE DIREITO DA UNIVERSIDADE DE SÃO PAULO

SÃo PAULO

2012 
KARINNE ANSILIERO ANGELIN

\title{
DANO INJUSTO COMO PRESSUPOSTO DO DEVER DE INDENIZAR
}

\author{
Dissertação de mestrado apresentada ao \\ Departamento de Direito Civil da Faculdade de \\ Direito da Universidade de São Paulo, realizada \\ sob orientação do Professor Associado José \\ Fernando Simão.
}

FACULDADE DE DIREITO DA UNIVERSIDADE DE SÃO PAULO

SÃO PAULO 
ANGELIN, Karinne A., Dano injusto como pressuposto do dever de indenizar, dissertação (mestrado), Faculdade de Direito da Universidade de São Paulo, 2012.

RESUMO: O objetivo desta dissertação é demonstrar que a responsabilidade civil aquiliana, no ordenamento jurídico brasileiro, tem como pressuposto fundamental a causação de dano injusto. Esse objetivo justifica-se porque existem posições doutrinárias, conhecidas como "direito de danos", que defendem a desnecessidade do dano injusto para que seja deflagrada a estrutura de responsabilização civil. Analisam-se, para tanto, a estrutura e a finalidade da responsabilidade civil, bem como o seu enquadramento no sistema jurídico brasileiro.

Palavras-chave: Responsabilidade. Responsabilidade civil. Pressupostos. Função. Sanção civil. Direito de danos. Dano injusto. 
ANGELIN, Karinne A., The unfair damage as a presupposition of the duty to indemnify, dissertation (master's degree), Faculty of Law of the University of São Paulo, 2012.

\begin{abstract}
The aim of this dissertation is to show that the non-contractual civil liability in the Brazilian legal order has as a fundamental presupposition the causation of the unfair damage. This aim is justifiable because there are doctrinaire opinion, known as "damage law", that advocate the unnecessariness of the unfair damage to be triggered the structure of civil liability. It analyzes, therefore, the structure and the goal of the civil liability, as well as its fitting into the Brazilian legal system.
\end{abstract}

Key-words: Responsibility. Civil liability. Presupposition. Function. Civil sanction. Damage law. Unfair damage. 
ANGELIN, Karinne A., Danno ingiusto come presupposto del dovere di indennizzare, dissertazione di master, Facoltà di Diritto dell’Università di San Paolo, 2012.

RIASSUNTO: L'obiettivo di questa dissertazione è dimostrare che la responsabilità civile aquiliana, nell'ordinamento giuridico brasiliano, ha come presupposto fundamentale la causa del danno ingiusto. Questo obiettivo si giustifica perchè esistono posizioni dottrinarie conosciute come "diritto dei danni", che difendono la mancanza di necessita del danno ingiusto perchè sia deflagrata la struttura della responsabilità civile. Si analizza pertanto la struttura e la finalità della responsabilità civile, così come il suo inquadramento nel sistema giuridico brasiliano.

Parole-chiave: Responsabilità. Responsabilità civile. Presupposti. Funzione. Sanzione civile. Diritto dei danni. Danno ingiusto. 


\section{SUMÁRIO}

Introdução

Capítulo 1 - Responsabilidade civil: noções gerais

1.1. Responsabilidade e responsabilidade em sentido jurídico

1.2. Responsabilidade penal, civil e administrativa . 16

1.3. A responsabilidade civil como fonte das obrigações 22

Capítulo 2 - Notícia histórica sobre a evolução da responsabilidade civil no sistema romano-germânico 28

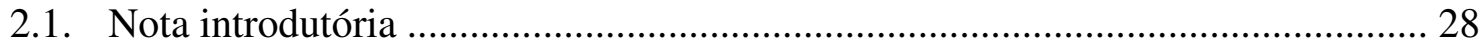

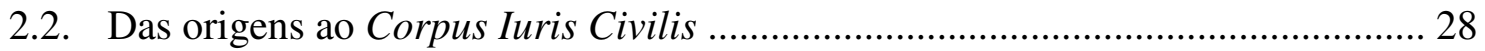

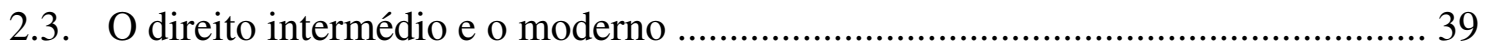

2.3.1. As codificações francesa e alemã ....................................................... 42

2.3.2. O direito brasileiro .......................................................................... 43

Capítulo 3 - Estrutura da responsabilidade civil ..................................................... 45

3.1. Pressupostos da responsabilidade civil .............................................................. 45

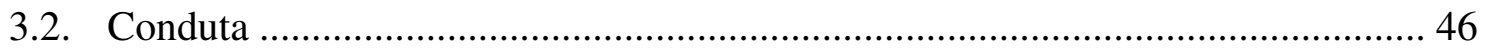

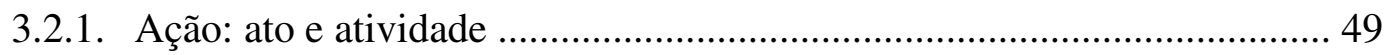

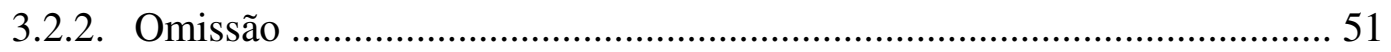

3.2.3. Valoração da conduta: noção de ato ilícito e conduta culposa ................. 53

3.2.3.1. Que é ato ilícito? .................................................................... 53

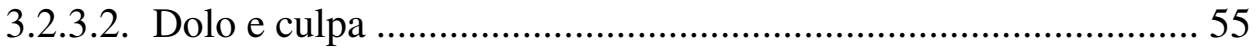

3.2.3.3. Normas de pré-exclusão da ilicitude da conduta ....................... 60

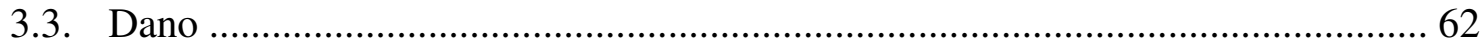

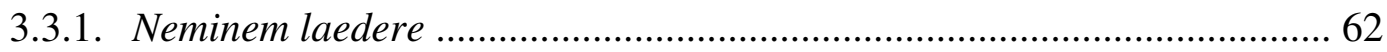

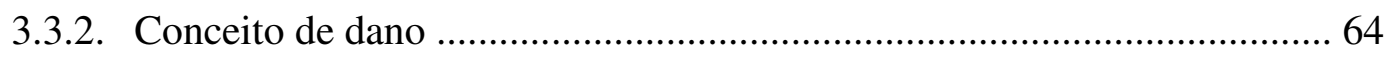

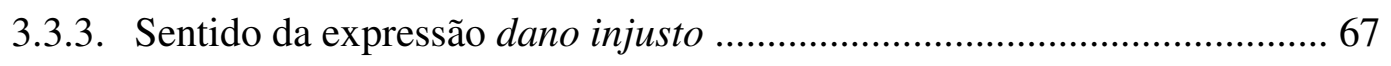

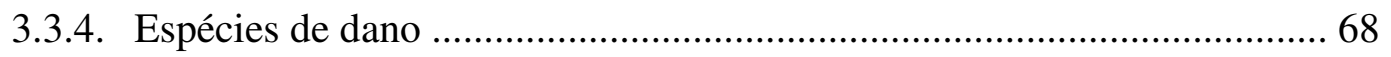

3.3.4.1. Danos patrimoniais e danos não patrimoniais ............................ 69

3.3.4.1.1. Danos emergentes e lucros cessantes ..................... 70 
3.3.4.2. Danos diretos, danos indiretos e danos reflexos ....................... 77

3.3.4.3. Danos obrigacionais e danos extraobrigacionais ..................... 79

3.3.4.4. Dano social ......................................................................... 80

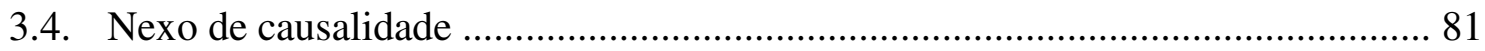

3.4.1. Relação de causalidade e relação de imputação. $\mathrm{O}$ nexo físico e o nexo

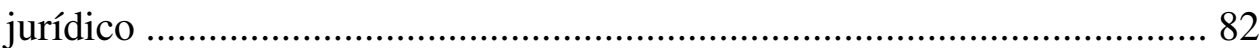

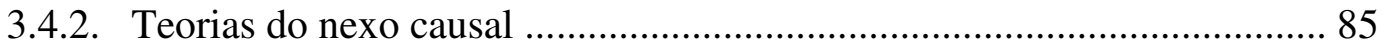

3.4.3. Causas de exclusão do nexo causal. Distinção entre exclusão e não

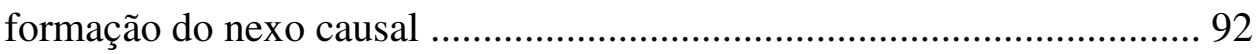

Capítulo 4 - Desconstrução da estrutura clássica da responsabilidade civil? ............ 96

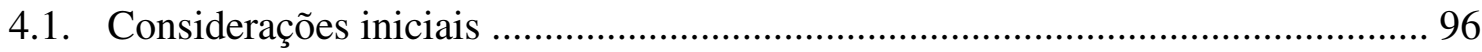

4.2. Os fatores da transformação social e seus reflexos na responsabilidade civil .....97

4.3. As alterações nos pressupostos da responsabilidade civil ................................ 104

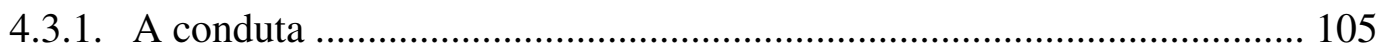

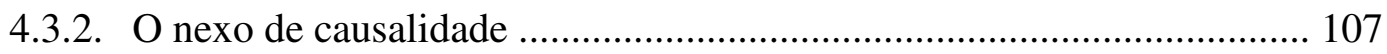

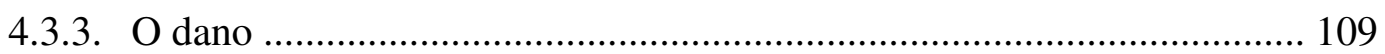

4.3.3.1. Responsabilidade civil sem dano? .......................................... 109

4.3.3.2. Argumentos em defesa da responsabilidade civil sem dano. Propostas para sua concretização no ordenamento jurídico brasileiro 110

4.3.3.3. Desnecessidade de substituição da estrutura atual de responsabilidade civil por um "direito de danos" ................... 122 4.3.3.3.1. Responsabilidade civil e punição do causador do

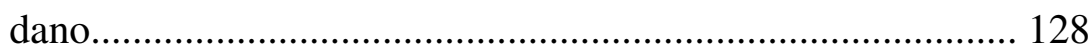

4.3.3.3.2. Indenização sem dano............................................. 131

Capítulo 5 - O dano injusto como pressuposto do dever de indenizar ..................... 138

5.1. A sanção própria da responsabilidade civil em sentido estrito: o dever de indenizar

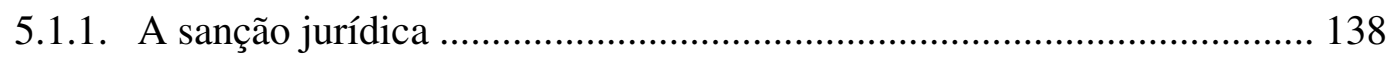

5.1.2. O dever de indenizar enquanto espécie de sanção civil ......................... 142 
5.2. O dano injusto como código comunicacional próprio da responsabilidade civil

Conclusão 156

Bibliografia 158 


\section{INTRODUÇÃO}

Esta dissertação pretende realizar uma análise dogmática da responsabilidade civil aquiliana no sistema jurídico brasileiro, para com isso investigar a possibilidade de ela restar configurada ainda que não haja dano injusto.

Esse objetivo se justifica porque há corrente doutrinária, conhecida por "direito de danos", que, afirmando haver, na sociedade contemporânea, ineficiência do instituto da responsabilidade civil, propugna por uma ampliação de suas funções e radical alteração de seus pressupostos, defendendo, inclusive, a prescindibilidade do elemento dano.

Como ficará demonstrado, o dano injusto é o pressuposto fundamental que o direito elegeu para deflagrar a estrutura de responsabilização civil, a qual tem como única sanção o dever de indenizar.

Para chegar-se a essa conclusão, estruturou-se o estudo da seguinte forma:

No primeiro capítulo, são traçadas algumas noções elementares, a fim de conceituar o que se entende por responsabilidade civil, extremando-a da responsabilidade em sentido ético e das responsabilidades penal e administrativa.

O segundo capítulo consiste em uma breve análise histórica da responsabilidade civil, tendo como fio condutor o processo de sua emancipação em relação à responsabilidade penal, com a delimitação de sua função: a reparação de danos injustos.

No terceiro capítulo, analisa-se a estrutura da responsabilidade civil em seus pressupostos clássicos.

No quarto capítulo, submete-se à prova a coerência de um "direito de danos". Para tanto, são expostas, primeiramente, as premissas nas quais se apoiam os autores que propugnam por um "direito de danos", bem como suas propostas para a concretização dessa nova estrutura de responsabilização civil. Em seguida, procura-se 
demonstrar a incoerência de tais propostas e a desnecessidade de um "direito de danos" no âmbito do ordenamento jurídico brasileiro.

No último capítulo, apresenta-se o enquadramento do subsistema de responsabilidade civil no sistema jurídico brasileiro, corroborando o entendimento defendido de que a ampliação do objeto da responsabilidade civil, tal qual proposta pelos defensores do "direito de danos", não é possível. Tornou-se imprescindível o recurso à teoria geral do direito, já que é a partir dela que se compreendem as categorias jurídicas. $\mathrm{O}$ campo de análise, porém, foi alargado. Como instrumento de reforço à teoria geral do direito, utilizou-se a teoria dos sistemas de Niklas Luhmann. É claro que outras teorias poderiam igualmente servir a esse fim, mas, por razões de afinidade, preferiu-se a de Luhmann. 


\section{CAPÍTULO 1 - RESPONSABILIDADE CIVIL: NOÇÕES GERAIS}

\subsection{Responsabilidade e responsabilidade em sentido jurídico}

Responsabilidade é conceito indissociável da pessoa humana. É noção que decorre das ações dos homens, estando presente, portanto, em todos os aspectos da realidade social, não sendo, pois, um fenômeno exclusivamente jurídico. É, sobretudo, uma necessidade da vida em sociedade ${ }^{1}$.

Na filosofia, o termo responsabilidade está intrinsecamente associado à ideia de liberdade. Diz-se que o fundamento da responsabilidade é o livre-arbítrio, já que em um mundo onde todos os acontecimentos estão pré-determinados, restaria sem razão qualquer forma de responsabilização dos indivíduos, meros instrumentos da determinação.

A análise, em filosofia, fica, portanto, circunscrita a dois extremos: um de plena responsabilidade, tendo por base a liberdade dos indivíduos, e outro de completa irresponsabilidade, com fulcro no determinismo ${ }^{2}$.

Em “O existencialismo é um humanismo", Jean-Paul Sartre, partindo da premissa de que a existência precede a essência - é dizer, o homem primeiro existe e, em seguida, define-se para tornar-se como ele se quer -, conclui que o homem deve ser considerado totalmente responsável pela sua existência - pelo que é -. Isso não importa dizer tão somente que o homem é responsável estritamente por sua individualidade, pois,

\footnotetext{
${ }^{1}$ Pontes de Miranda faz a seguinte comparação: “a noção de responsabilidade é necessária à adaptação do homem à vida social, e tão imprescindível à vida comum como os órgãos humanos se fizeram necessários às funções que lhes cabem”. E prossegue: "Hoje, não há muita diferença entre a faca do homem que sacrifica o boi, o porco ou o carneiro, para viver, e a pena do magistrado que decreta a prisão do criminoso ou a reparação de danos. Entre os dois atos, há a mesmidade de fim, a adaptação à vida animal. Esse, à vida social. Ali, necessidade biológica; aqui sociológica”. Tratado de Direito Privado - Parte Especial - Tomo LIII Direito das Obrigações: Fatos ilícitos absolutos. Atos-fatos ilícitos absolutos. Atos ilícitos absolutos. Responsabilidade. Danos causados por animais. Coisas inanimadas e danos. Estado e servidores. Profissionais, $3^{\mathrm{a}}$ ed., reimpressão, Rio de Janeiro, Borsoi, 1972, p. 36.

${ }^{2}$ Não é objeto desta dissertação a análise dessas correntes filosóficas. Apenas para que se esclareça o significado em que esses termos estão sendo empregados: determinismo é "a doutrina que reconhece a universalidade do princípio causal e portanto admite também a determinação necessária das ações humanas a partir de seus motivos"; liberdade, por sua vez, é "autodeterminação ou autocausalidade, [...] é ausência de condições e de limites”. ABBAGNANO, Nicola, Dicionário de filosofia, $5^{\mathrm{a}}$ ed., tradução da $1^{\mathrm{a}}$ edição brasileira coordenada e revista por Alfredo Bossi, revisão da tradução e tradução dos novos textos Ivone Castilho Benedetti, São Paulo, Martins Fontes, 2007, verbetes “determinismo" e "liberdade”, p. 287 e 699.
} 
ao escolher por si mesmo, ele escolhe por todos os homens. Sua responsabilidade é, dessa forma, bastante ampla, por envolver a humanidade como um todo ${ }^{3}$.

Esse é um pensamento em que a responsabilidade pessoal está totalizada, de modo que fica inviabilizada qualquer relação de responsabilidade que se pretenda ver estabelecer. Não há instâncias - sociedade, Deus - perante as quais o indivíduo deve responder. Ele responde perante si mesmo; está condenado a arcar com o peso de toda e qualquer responsabilização.

Este é o sentimento de responsabilidade da sociedade contemporânea.

De fato, não é outra a constatação feita por Klaus Günther ao afirmar que é possível hoje falar em um "novo existencialismo". Para o autor, a sociedade civil contemporânea pode ser denominada sociedade da responsabilidade, pois essa palavra está intimamente ligada ao seu espírito objetivo. Operou-se uma redistribuição da responsabilidade, que da sociedade, da natureza, do destino, da história passou para o indivíduo. Cada um é considerado responsável pela sua condição de existência, cabendolhe escolher sua forma de vida, bem como os princípios que irão reger sua convivência. Como consequência desse novo esquema de imputação tem-se a atribuição ilimitada de responsabilidade aos indivíduos ${ }^{4}$.

Enquanto produto de um ato humano, a responsabilidade pode ser examinada de duas formas: como um estado do indivíduo perante ele mesmo e como uma relação.

\footnotetext{
${ }^{3}$ SARTRE, Jean-Paul, O existencialismo é um humanismo, tradução de João Batista Kreuch, Petrópolis, Vozes, 2010, p. 23-31. O existencialismo sartreano pode ser condensado na frase: "O homem está condenado a ser livre. Condenado, pois ele não se criou a si mesmo, e, por outro lado, contudo, é livre, já que, uma vez lançado no mundo, é o responsável por tudo que faz”. Ibid., p. 33.

${ }^{4}$ GÜNTHER, Klaus, Responsabilização na sociedade civil, in Teoria da responsabilidade no estado democrático de direito: textos de Klaus Günther, organizadoras PÜSCHEL, Flávia Portella; MACHADO, Marta Rodriguez de Assis, Série direito em debate. Direito desenvolvimento justiça, São Paulo, Saraiva, 2009, p. 1-26. Para ilustrar a redistribuição de responsabilidades na sociedade civil global, o autor observa: "Desvantagens sociais e pobreza não se explicam mais por uma posição de classe ou uma distribuição desigual de chances e bens, mas apenas por decisões erradas do indivíduo que cai abaixo da linha de pobreza. O comportamento criminoso não mais é atribuído a déficits na socialização ou na estrutura social, mas apenas ao criminoso individual, considerado em si mesmo culpado por seu ato”. Ibid., p. 12.
} 
$\mathrm{Na}$ primeira forma, tem-se o que pode ser denominado autorresponsabilidade ou responsabilidade interna, isto é, responsabilidade que o indivíduo tem perante si mesmo. Para se avaliar se há ou não autorresponsabilização, a única perquirição a ser feita remete à verificação do estado de consciência do indivíduo. Basta estar presente um sentimento de responsabilização com relação a um seu determinado pensamento, a um seu determinado comportamento, para que o sujeito considere-se autorresponsabilizado. Trata-se de mecanismo de imputação de atos de si para si mesmo.

$\mathrm{Na}$ segunda forma, o indivíduo responsabiliza-se ou é responsabilizado perante outro ente, num esquema que visa a estabelecer um vínculo entre dois polos ou termos. Daí, relação de responsabilidade. Pode-se aqui falar em heterorresponsabilidade ou responsabilidade externa, a qual será qualificada como social, ou não, conforme o ente que ocupe o outro polo da relação seja, ou não, pertencente ao corpo social ${ }^{5}$.

A heterorresponsabilidade social, espécie de relação social, é objeto de estudo por parte dos chamados sistemas sociais. Fala-se em responsabilidade moral, responsabilidade institucional, responsabilidade jurídica, entre outras, mas todas elas relacionadas ao convívio dos homens em sociedade.

Visando a encontrar um ponto comum entre esses diferentes aspectos da responsabilidade no campo social, José de Aguiar Dias afirma que essa palavra e todos os seus vocábulos cognatos exprimem a ideia de "equivalência de contraprestação", de "correspondência", donde ser possível atribuir-lhe, sem muita perfeição técnica, a noção de "repercussão obrigacional da atividade do homem". Assim, é que, valendo-se dos ensinamentos de G. Marton, o autor concebe a responsabilidade como termo dependente da pré-existência de um dever ou de uma obrigação ${ }^{6}$.

\footnotetext{
${ }^{5}$ Como exemplo de relação não social, pode-se citar a relação do fiel para com seu deus; de relação social, a amizade.

${ }^{6}$ DIAS, José de Aguiar, Da responsabilidade civil - Tomo I, 5a ed., Rio de Janeiro, Forense, 1973, p. 8. Segundo G. Marton, a responsabilidade exige a presença de dois elementos: (a) pré-existência de um dever (obrigação) e (b) violação desse dever (obrigação). Daí afirmar que responsabilidade é necessariamente uma reação provocada pela violação de um dever. MARTON, G., Les fondements de la responsabilité civile Révision de la doctrine - Essai d'un système unitaire, Paris, Librairie du Recueil Sirey, 1938, p. 258 e seguintes. Para fins de responsabilidade civil, pode-se pensar no dever, genérico, de não causar danos injustos (neminem laedere). Isso evita ser feita qualquer interpretação no sentido de que, para haver responsabilização civil, é preciso necessariamente haver conduta ilícita. Como será visto adiante (capítulo 3),
} 
Também Klaus Günther observa que a palavra responsabilidade é empregada em diversos contextos ${ }^{7}$, querendo referir-se a fenômenos distintos. No entanto, salienta ser possível elencar pelo menos duas características comuns a todas essas aplicações do termo: (i) a estrutura formal - estabelece-se sempre a responsabilidade de uma pessoa perante outras pessoas por uma ação, omissão ou consequência -; e (ii) a função social - não se permite que as situações eleitas como indesejáveis deixem de ser tidas como consequência de uma conduta de alguém. Dessa forma, faz-se o isolamento, a escolha do agente a quem se imputará o acontecimento ${ }^{8}$.

Como subsistema social ou "sistema de $2^{\text {a }}$ ordem", o direito, ao lado dos outros subsistemas sociais - econômico, político, cultural -, está funcionalizado a um sistema maior, que é a sociedade, o que, entretanto, não lhe retira as características básicas a qualquer sistema, quais sejam "identidade própria" e "autonomia operacional"9.

O sistema jurídico pode ser definido como "conjunto de vários elementos que se movimentam mantendo relações de alguma constância". Esses elementos, os quais são heterogêneos, e mantêm relações variadas entre si, são as normas, as instituições, os operadores do direito, a doutrina, a jurisprudência ${ }^{10}$.

quem pratica ato lícito (ex.: legítima defesa) e causa dano injusto a terceiro também terá de indenizar, não porque sua conduta mereça reprovação, mas porque o sistema jurídico entende não ser justo que o dano (consequência da conduta) permaneça na esfera jurídica do lesado. Não há aqui violação de outro dever que não o de não causar danos injustos. Nesse sentido, Pontes de Miranda afirma: “A reparação do dano (...) pode ser por haver contrariedade a direito, ou sem haver contrariedade a direito. Se há contrariedade a direito, há ilicitude (...); se não há contrariedade a direito, não há ilicitude, e então a reparação se funda em que a esfera jurídica de alguém foi invadida sem que o ato invadente se considere contrário a direito". Tratado de Direito Privado - Parte Especial - Tomo LIII - Direito das Obrigações: Fatos ilícitos absolutos. Atos-fatos ilícitos absolutos. Atos ilícitos absolutos. Responsabilidade. Danos causados por animais. Coisas inanimadas e danos. Estado e servidores. Profissionais, $3^{\mathrm{a}}$ ed., reimpressão, Rio de Janeiro, Borsoi, 1972, p. 121.

${ }^{7}$ Contudo, sempre no campo social.

${ }^{8}$ GÜNTHER, Klaus, op. cit., p. 5-8. Quanto à segunda característica, trata-se de função de estruturação, consistente em "estruturar a comunicação social acerca de problemas sociais, conflitos, riscos, perigos e danos de maneira que estes sejam atribuídos a pessoas singulares, a indivíduos, e não a estruturas e processos supraindividuais: à sociedade, à natureza ou ao destino". Ibid., p. 7-8.

${ }^{9}$ AZEVEDO, Antonio Junqueira, $O$ direito como sistema complexo e de $2^{a}$ ordem; sua autonomia. Ato nulo e ato ilícito. Diferença de espírito entre responsabilidade civil e penal. Necessidade de prejuízo para haver direito de indenização na responsabilidade civil (parecer), in Estudos e pareceres de direito privado, São Paulo, Saraiva, 2004, p. 26-28. Francisco Amaral observa que a opção metodológica de estudo do direito pela análise sistêmica tem sido bastante adotada pela doutrina, sobretudo por aquela da teoria do direito. Segundo o autor, a vantagem desse tipo de abordagem é que se consegue uma perspectiva global da experiência jurídica. Nas suas palavras: "A análise sistêmica, mais propriamente análise sociológica dos sistemas jurídicos, é um processo que tem como objetivo estudar o direito em sua totalidade e complexidade, para melhor compreender os seus problemas estruturais e o seu funcionamento interno, desenvolvendo-se, por isso, a partir de uma concepção sistêmica interdisciplinar, pluralista e construtivista". Direito civil: introdução, $7^{\mathrm{a}}$ ed. rev., atual. e aum., Rio de Janeiro, Renovar, 2008, p. 35-41.

${ }^{10}$ AZEVEDO, Antonio Junqueira, op. cit., p. 26. 
Como elementos desse sistema, o fato jurídico e a relação jurídica são categorias que se revestem de especial interesse, pois o problema da responsabilidade jurídica não é senão o da juridicização de especiais fatos sociais, juridicização esta cujo efeito é o estabelecimento de um vínculo entre sujeito responsável pela reparação e vítima.

Em outras palavras, o papel do direito, como um sistema social normativo, é o de reger relações intersubjetivas. Por óbvio, nem todas as relações intersubjetivas serão jurídicas $^{11}$. Apenas haverá relação jurídica quando se compuser no mundo dos fatos o suporte fático suficiente descrito pela norma jurídica, que, desta feita, incidirá, transformando-o em fato jurídico, o qual, por sua vez, será hábil a produzir os efeitos previstos pela norma, por exemplo, criar, modificar ou extinguir relações jurídicas ${ }^{12}$. Esse o critério que permite qualificar um determinado fato social como jurídico e atribuir-lhe os efeitos da responsabilidade jurídica.

Com muita propriedade, Maurício Bunazar estabeleceu uma distinção terminológica entre dois conceitos-chaves, conferindo ao estudioso da matéria esclarecimentos preliminares à compreensão do instituto ora analisado.

Pela importância, transcreve-se:

"A responsabilidade jurídica é o produto das normas jurídicas que tratam do dever imposto a alguém de responder (= arcar com as conseqüências normativamente impostas) pelos efeitos de atos próprios, atos de terceiro e fato de animais e coisas, normas estas que uma vez incidentes, conferem ao sujeito de

\footnotetext{
${ }^{11}$ LUMIA, Giuseppe, Elementos de teoria e ideologia do direito, tradução de Denise Agostinetti, São Paulo, Martins Fontes, 2003, p. 99-100.

${ }^{12}$ A teoria do fato jurídico foi muito bem desenvolvida por Pontes de Miranda. Cf.: Tratado de Direito Privado - Parte Geral - Tomo I - Introdução. Pessoas físicas e jurídicas, $3^{\mathrm{a}}$ ed., Rio de Janeiro, Borsoi, 1970; Tratado de Direito Privado - Parte Geral - Tomo II - Bens. Fatos Jurídicos, $3^{\text {a }}$ ed., Rio de Janeiro, Borsoi, 1970. Quanto à relação jurídica, vide Manuel António Domingues Andrade, Teoria Geral da Relação Jurídica, v. I, Coimbra, Almedina, 2003; VILANOVA, Lourival, Causalidade e relação no direito, $4^{\mathrm{a}} \mathrm{ed}$. revista, atualizada e ampliada, São Paulo, Editora Revista dos Tribunais, 2000, p. 110 e seguintes.
} 
direito o status de responsável, cuja antítese é o status de irresponsável"13.

Por sua vez:

“A responsabilização jurídica é a responsabilidade jurídica potência - em movimento (ato), ou seja, é o resultado da deflagração do funcionamento da estrutura jurídica de imputação de conseqüências aos sujeitos" $" 14$.

Tem-se, pois, que, deflagrada a responsabilização, o sujeito responsável passará a ostentar posição jurídica passiva consistente ou em uma pura sujeição, caso da sanção penal e de algumas sanções administrativas, ou em uma obrigação completa, é dizer, com o dever de adimplir (obrigação) e com a sujeição à execução forçada caso não o faça.

A partir dessas considerações e dos conceitos fixados, será feita uma abordagem sucinta das espécies de responsabilidade jurídica: penal, administrativa e civil.

\subsection{Responsabilidade penal, civil e administrativa}

A divisão da Ciência do Direito em ramos é produto de uma escolha metodológica que encontra suas raízes no Direito Romano com os trabalhos de Ulpiano. Dentro do jus civile, o jurisconsulto dividiu o Direito em Direito Público e Direito Privado. O primeiro tinha por objeto a res pública romana - interesse público - e o segundo visava a atender o interesse de cada um - interesse privado ${ }^{15}$.

13 BUNAZAR, Maurício B., Taxonomia da sanção civil: para uma caracterização do objeto da responsabilidade civil, in Revista Juris da Faculdade de Direito, Fundação Armando Alvares Penteado, v. 5 , janeiro a junho/2011, São Paulo, FAAP, 2010, p. 39.

${ }^{14}$ Idem.

${ }^{15}$ Ulp. 1 inst., D. 1, 1, 1, 2: "Publicum ius est, quod ad statum rei Romanae spectat, privatum, quod ad singulorum utilitatem: sunt enim quaedam publice utilia, quaedam privatim".

Nesta dissertação, as reproduções das fontes jurídicas romanas deram-se, para o Digesto e as Institutas, de acordo com a edição crítica de Paulus Krueger e Theodorus Mommsen: Corpus Iuris Civilis, volumen primum, Institutiones, recognovit Paulus Krueger; Digesta, recognovit Theodorus Mommsen, 22 ${ }^{\mathrm{a}}$ ed., Berlim, Weidmann, 1973. E para as Institutas de Gaio, conforme edição: BAVIERA, Johannes, Fontes Ivris 
A partir daí, muito se escreveu sobre o tema, surgindo, sobretudo nos séculos XVIII e XIX, diversas teorias que ou procuram negar a existência dessa dicotomia - teorias monistas ${ }^{16}$ - ou aceitando-a - teorias dualistas - justificam-na de formas diversas.

Efetivamente, considera-se que o ordenamento jurídico é um todo unitário, entretanto, para fins didáticos, através de uma perspectiva dogmática, propõem-se a divisão do direito em ramos, pois isso permite uma abordagem das especificidades de conteúdo ínsitas a cada ramificação ${ }^{17}$.

Os critérios classicamente utilizados pelos autores dualistas para diferenciar as normas jurídicas de direito público das de direito privado contrapõem, em geral, o social ao individual.

Dentre esses critérios, estão ${ }^{18}$ :

(i) o do interesse dominante na relação jurídica: é a teoria de Ulpiano, segundo a qual, a norma é de direito público quando visa à proteção dos interesses gerais e de direito privado quando destinada à proteção do interesse particular ${ }^{19}$;

(ii) $\quad$ o do fim ou da finalidade da norma jurídica: esse critério foi formulado por Savigny. Por ele, norma de direito público é aquela cujo fim é o Estado, sendo, por sua vez, de direito privado quando o fim é o indivíduo ${ }^{20}$;

Romani Antejvstiniani (FIRA) - Pars Altera - Avctores, Firenze, G. Barbèra, 1940. Já as traduções livres pautaram-se na tradução espanhola do latim de DEL CORRAL, D. Ildefonso Luis García, Cuerpo del derecho civil romano, Primera Parte - Tomo $1^{o}$ - Instituta-Digesto, Barcelona, Editorial Lex Nova, 1889; e Tomo $3^{\circ}$ - Digesto, Barcelona, Editorial Lex Nova, 1897.

${ }^{16}$ Dentre os defensores da teoria monista, vide KELSEN, Hans, Teoria pura do direito, $6^{\mathrm{a}}$ ed., $5^{\mathrm{a}}$ tiragem, tradução João Baptista Machado, São Paulo, Martins Fontes, 1998.

${ }^{17}$ A favor da manutenção da distinção entre direito público e direito privado, Virgílio Afonso da Silva, $A$ constitucionalização do direito. Os direitos fundamentais nas relações particulares, $1^{\mathrm{a}}$ ed., $2^{\mathrm{a}}$ tiragem, São Paulo, Malheiros, 2005, p. 172 -174.

${ }^{18}$ Não é objetivo desta dissertação fazer uma análise exaustiva dos critérios de classificação do direito em público ou privado. Apenas, citam-se as principais teorias a esse respeito.

${ }^{19}$ Cf.: AMARAL, Francisco, op. cit., p. 107-110.

20 SAVIGNY, Friedrich Karl von, Sistema del diritto romano attuale, volume primo, traduzione dall'originale tedesco di Vittorio Scialoja, Torino, Unione Tipografico Editrice, 1886, p. 48 e seguintes. Nas palavras de Savigny: "no direito público, o todo se apresenta como finalidade e o indivíduo resta em segunda ordem. Já no direito privado, qualquer indivíduo por si mesmo é tido como finalidade e cada relação jurídica serve apenas como meio para sua existência ou para suas particulares condições”. Ibid., p. 49. 
(iii) o da consequência da violação da norma: é atribuído a Thon, o qual entende que a norma será de direito público quando a sua violação ensejar ao Estado pretensão para afastamento da situação ilícita. Ao passo que será de direito privado quando a sua violação ensejar, não ao Estado, mas ao particular tal pretensão ${ }^{21}$;

(iv) $\quad$ o do vínculo de coordenação ou subordinação: esse critério contempla a teoria do ius imperii, pela qual as normas serão de direito público quando regem relações jurídicas em que os sujeitos estão em situação de subordinação e serão de direito privado quando os sujeitos da relação jurídica estiverem em situação de coordenação ${ }^{22}$;

(v) o da natureza dos sujeitos: se a norma disciplina atividade do Estado, ela é de direito público, ao passo que, se ela disciplina a atividade dos indivíduos, então, ela é de direito privado ${ }^{23}$.

(vi) o da função que exercem no sistema jurídico: ao direito público é atribuída "a função de direcionar interesses divergentes no sentido de um objetivo comum por meio de regras imperativas e geralmente restritivas", enquanto que ao direito privado cabe "a função de permitir a coexistência de interesses individuais divergentes, por meio de regras que devem servir para tornar menos freqüentes e menos ásperos os conflitos e, outras regras que devem servir para solucioná-los depois que eles surgirem"24.

Esses critérios encontram-se, de alguma forma, refletidos na separação da responsabilidade jurídica em civil e penal. São comuns afirmações no sentido de que, enquanto na responsabilidade penal o interesse lesado é público, na responsabilidade civil é particular; de que na responsabilidade penal o lesante responde perante a sociedade, e na responsabilidade civil ele responde perante a vítima; de que a finalidade da

\footnotetext{
${ }^{21}$ THON, August, Norma giuridica e diritto soggettivo: indagini di teoria generale del diritto: indagini di teoria generale del diretto, seconda edizione, prima traduzione del Prof. Alessandro Levi, Padova, CEDAM, 1951, p. 113 e seguintes.

${ }^{22}$ Cf.: AMARAL, Francisco, op. cit., p. 107-110.

${ }^{23}$ Cf.: AMARAL, Francisco, idem.

${ }^{24}$ BOBBIO, Norberto, Análise funcional do direito: tendências e problemas, in Da estrutura à função: novos estudos de teoria do direito, tradução de Daniela Beccaccia Versiani, revisão técnica de Orlando Seixas Bechara, Renata Nagamine, Barueri, Manole, 2007, p. 11.
} 
responsabilidade penal é a punição do criminoso, enquanto que a da responsabilidade civil é a reparação do dano.

A problematização desses argumentos utilizados para diferenciar a responsabilidade civil da responsabilidade penal leva à constatação de que, se não são de todo deficientes, são ao menos insuficientes para explicá-la.

Flávia Portella Püschel e Marta Rodriguez de Assis Machado investigaram as principais falhas que demonstram a necessidade de uma rediscussão das fronteiras entre os ramos do direito. Verificaram, resumidamente, que $^{25}$ :

(i) a proteção conferida pela responsabilidade civil aos interesses difusos, que, indubitavelmente, caracterizam-se como interesses sociais, contesta o tradicional critério de distinção da responsabilidade civil da penal com base no tipo de interesse protegido;

(ii) a tendência de os ordenamentos jurídicos introduzirem a reparação do dano no sistema penal, inclusive como forma mesmo de sanção penal - o Código de Trânsito Brasileiro, v.g., em seu artigo 297 e parágrafos, impõe multa reparatória em favor da vítima ou seus sucessores como penalidade a ser aplicada sempre que houver prejuízo material resultante dos crimes regidos por esse diploma ${ }^{26}$ e também de a punição ser trazida para a esfera cível - pode-se citar, v.g., os punitive damages - desafia o critério que se assenta no tipo de resposta e sua finalidade (se dever de indenização, reparação; se pena, punição) ${ }^{27}$;

\footnotetext{
${ }^{25}$ PÜSCHEL, Flávia Portella; MACHADO, Marta Rodriguez de Assis, Questões atuais acerca da relação entre as responsabilidades penal e civil, in http://www.gv.br/biblioteca/pe/SP000503359.pdf. Acesso em janeiro de 2011.

26 Não se concorda com este posicionamento específico das autoras. Entende-se que a "multa reparatória", apesar do nome, é indenização e, portanto, sanção de natureza cível, embora seja aplicada pelo juízo criminal. Nos termos do que dispõe o artigo 297, caput e parágrafos, do Código de Trânsito Brasileiro, trata-se de valor destinado à reparação de prejuízo material resultante do crime, sendo devido à vítima ou aos seus sucessores. Quando da apuração, na esfera cível, dos prejuízos totais sofridos pela vítima em razão do crime, o valor fixado a título de "multa reparatória" pelo juízo criminal deve ser descontado.

${ }^{27}$ Considerações sobre os punitive damages serão expostas no capítulo 4 desta dissertação.
} 
(iii) a adoção pelo Direito Penal de critérios de imputação típicos do direito civil - como no caso da responsabilização penal da pessoa jurídica, em que a pena recai sobre ente desprovido de culpa individual - aproxima as esferas de responsabilidade, questionando as distinções que se apoiam nos pressupostos de responsabilização.

José de Aguiar Dias versou também o tema e chegou a uma conclusão que traz grande contribuição ao presente estudo. Para ele, o fundamento da responsabilidade civil e da responsabilidade penal é praticamente o mesmo. A diferença entre elas está nas condições que as determinam - leia-se, seus pressupostos e suas consequências -, "porque uma é mais exigente do que a outra, quanto ao aperfeiçoamento dos requisitos que devem coincidir" 28 .

A responsabilidade penal, a responsabilidade civil e a responsabilidade administrativa são institutos concebidos para tratar da violação do ordenamento jurídico e da consequente necessidade de manutenção de sua integridade: o sistema elenca as situações que entende indesejáveis e imputa-lhes sanções. Ontologicamente, portanto, esses institutos são iguais.

Em que consistiria, então, a diferença entre eles? Se é correto afirmar que determinada contrariedade a direito terá consequências jurídicas cíveis, porque sobre ela incide norma de direito civil; que outra terá efeitos penais, posto que a norma incidente é de direito penal; ou que o efeito de uma outra dar-se-á na seara administrativa, pois que incidente norma de direito administrativo, essa é tão somente uma questão axiológica, e que, portanto, não dá resposta à pergunta, antes a reitera.

Maurício Bunazar torna bastante clara a distinção. Segundo ele, a diversidade entre esses sistemas reside no "quantum da sanção" e na "estrutura jurídica necessária para, em cada caso, a deflagrar"29.

\footnotetext{
${ }^{28}$ DIAS, José de Aguiar, op. cit., p. 12-18.

29 BUNAZAR, Maurício B., Responsabilidade civil do incapaz: objetivação da culpa ou responsabilidade civil objetiva?, in Ensaios sobre responsabilidade civil na pós-modernidade, v. 2, coordenadores HIRONAKA, Giselda Maria Fernandes Novaes; SIMÃO, José Fernando, Porto Alegre, Magister, 2009, p. 285-311.
} 
Isoladamente considerados, os dois critérios são insuficientes para caracterizar as espécies de responsabilidade jurídica. Faz-se necessária a cumulação de ambos.

Dentre os sistemas de estabilização do ordenamento jurídico, o Direito Penal é o mais violento. A sanção penal constitui, claramente, a mais gravosa das sanções, privando os indivíduos de sua liberdade, ou, no extremo, retirando-lhes a própria vida (artigo $5^{\circ}$, inciso XLVII, letra $a$, da Constituição Federal). A legitimidade para tanto conferida a esse ramo do Direito justifica-se em razão de sua finalidade, que é a tutela dos bens jurídicos tidos, por um critério político de seleção, como os mais significativos à manutenção da sociedade.

Por essa razão, o Direito Penal deve funcionar como a última das medidas, ultima ratio, de que o ordenamento jurídico dispõe para assegurar sua manutenção, intervindo apenas quando os demais ramos mostrarem-se incapazes de proteger esses bens essenciais.

Isso também faz com que a estrutura de imposição da sanção ao responsável tenha de ser mais rigorosa do que a verificada nas esferas cível e administrativa, envolvendo: a ocorrência de uma conduta, culposa ou dolosa, prevista no tipo penal; a produção de um resultado; a constatação da existência de um nexo causal entre a conduta e o resultado; a ausência de causas excludentes de ilicitude; e a verificação da culpabilidade do agente, isto é, da possibilidade de reprovar-se o agente por ter cometido o fato criminoso $^{30}$.

Comparativamente e, em se tratando de responsabilidade civil, o Direito Civil impõe ao causador do dano o dever de indenizar, espécie de sanção, claramente, menos gravosa do que a de natureza penal. Consequentemente, utiliza-se também de um mecanismo de aplicação de sanção que é mais simplificado: em geral, basta a verificação de conduta, dano e nexo de causalidade entre conduta e dano para que o agente venha a ser responsabilizado. Prescinde-se do exame da culpabilidade do agente ${ }^{31}$.

\footnotetext{
${ }^{30}$ Ibid., p. 290-298.

${ }^{31}$ Ibid., p. 298-303.
} 
Já a responsabilidade administrativa vale-se, ora da estrutura de deflagração da responsabilidade civil, ora de um modelo muito próximo da responsabilidade penal. No primeiro caso, pense-se na causação de um dano a um particular por um agente público no exercício de sua função. Estar-se-á diante de uma estrutura de aplicação de sanção que é a da responsabilidade civil extracontratual. No segundo, pode-se pensar na imposição, por meio de procedimento administrativo disciplinar, de pena de demissão a um agente público - referido processo em muito se assemelha ao processo criminal, podendo culminar na aplicação de sanção bastante severa ${ }^{32}$.

\subsection{A responsabilidade civil como fonte das obrigações}

Convencionou-se denominar de fontes ou causas geradoras das obrigações os fatos jurídicos que dão origem ao vínculo obrigacional ${ }^{33}$. Assim, são fontes das obrigações o contrato, a gestão de negócios, o ato ilícito etc.

No direito romano, a primeira classificação das fontes das obrigações de que se tem notícia é a atribuída a Gaio. Em suas Institutas, o jurisconsulto distingue as obrigações que nascem dos contratos daquelas que nascem dos delitos ${ }^{34}$.

Em uma passagem do Digesto, acrescentou-se uma terceira fonte, as variae causarum figurae, visando, assim, a abranger espécies geradoras de obrigações que não se enquadravam nas duas categorias anteriores ${ }^{35}$.

\footnotetext{
32 Ibid., p. 304.

${ }^{33} \mathrm{Na}$ doutrina portuguesa: COSTA, Mário Júlio de Almeida, Direito das Obrigações, 9a ed. revista e aumentada, Coimbra, Almedina, 2001, p. 177; LEITÃO, Luís Manuel Teles de Menezes, Direito das Obrigações, v. I, $5^{\text {a }}$ ed., Coimbra, Almedina, 2006, p. 180; TELLES, Inocêncio Galvão, Direito das Obrigações, $7^{\text {a }}$ ed. revista e actualizada, Coimbra, Coimbra Editora, 1997, p. 57; VARELA, João de Matos Antunes, Das obrigações em geral, v. I, 10ª ed. revista e actualizada, Coimbra, Almedina, 2008, p. 203. Na doutrina brasileira: GOMES, Orlando, Obrigações, $8^{\mathrm{a}}$ ed., $4^{\mathrm{a}}$ tiragem, Rio de Janeiro, Forense, 1994, p. 3132; MONTEIRO, Washington de Barros; MALUF, Carlos Alberto Dabus, Curso de Direito Civil - Direito das obrigações $-1^{a}$ parte, vol. 4, $35^{\text {a }}$ ed., São Paulo, Saraiva, 2010, p. 48; RODRIGUES, Silvio, Direito Civil - Parte geral das obrigações, v. 2, 30ª ed., São Paulo, Saraiva, 2002, p. 8. PEREIRA,Caio Mário da Silva, Instituições de Direito Civil - Teoria geral das obrigações, v. II, $21^{\text {a }}$ ed., Rio de Janeiro, Forense, 2007 , p. 40.

${ }^{34}$ Cf.: Gai. 3, 88: "Nunc transeamus ad obligationes. Quarum summa diuiosio in duas species diducitur; omnis enim obligatio uel ex contractu nascitur uel ex delicto".

${ }^{35}$ Cf.: Gai. 2 aur., D. 44, 7, 1 pr.: "Obligationes aut ex contractu nascuntur, aut ex maleficio, aut proprio quodam iure ex variis causarum figuris”.
} 
Mas a tradicional classificação das fontes das obrigações, que preponderou durante todo o Direito Intermédio ${ }^{36}$, é a que se encontra referida nas Institutas de Justiniano: contratos, quase-contratos, delitos e quase-delitos ${ }^{37}$.

Já no período que antecedeu a pré-codificação francesa, Pothier aditou a esse quadrinômio um quinto termo, a lei, que foi acolhida pelo Code Civil (artigo 1.370), pelo Código Civil italiano de 1865 (artigo 1.097) e pelo Código Civil espanhol de 1889 (artigo 1.089). Da lei decorreriam as obrigações que se afirmava derivarem imediatamente da vontade do legislador, como a obrigação alimentícia ${ }^{38}$.

Porém, essa classificação das fontes das obrigações sofreu muitas críticas por carecer de rigor científico, restando, assim, superada tanto pela doutrina quanto pelas legislações que se seguiram. As principais falhas apontadas podem ser condensadas dessa forma: (i) no que tange à categoria dos quase-contratos (fatos lícitos voluntários, em que não há um acordo de vontades), reconheceu-se tratar de conceito impreciso, abrangente de situações heterogêneas, e que permitia reconduzir todas as obrigações ao dogma da vontade, por haver relutância em aceitar que alguém pudesse ser obrigado independentemente do seu consentimento; (ii) quanto à separação estabelecida entre delitos (ilícitos dolosos) e quase-delitos (ilícitos culposos), ela deixou de ter relevância desde que a responsabilidade civil, com a sua evolução, acabara atribuindo praticamente ${ }^{39}$ o mesmo tratamento às situações em que o dano resulta de um ato doloso e de um ato culposo. Além do mais, há casos de responsabilidade civil em que não se afere dolo ou culpa do lesante; (c) por fim, no que diz respeito à lei, não se atentou para o fato de que ela é causa mediata de todas as obrigações ${ }^{40}$.

\footnotetext{
${ }^{36}$ COSTA, Mário Júlio de Almeida, op. cit., p. 178; VARELA, João de Matos Antunes, op. cit., p. 205. Estes autores ainda recordam que, inclusive, as Ordenações adotaram a quadripartição justinianeia: Ordenações Afonsinas, Livro IV, Título 67; Ordenações Manuelinas, Livro IV, Título 52; Ordenações Filipinas, Livro IV, Título 76.

${ }^{37}$ Cf.: Inst. 3, 13, 2: "Sequens divisio in quattuor species diducitur: aut enim ex contractu sunt aut quasi ex contractu aut ex maleficio aut quasi ex maleficio".

${ }^{38}$ COSTA, Mário Júlio de Almeida, op. cit., p. 178-179; VARELA, João de Matos Antunes, op. cit., p. 205.

${ }^{39}$ Há um temperamento quando da fixação do montante da indenização à luz do que determinam o artigo 494 do Código Civil português e o artigo 944, parágrafo único, do Código Civil brasileiro.

${ }^{40}$ LEITÃO, Luís Manuel Teles de Menezes, op. cit., p. 181; VARELA, João de Matos Antunes, op. cit., p. 206-210.
} 
Atualmente, a doutrina, no geral, embora esboce algumas considerações, não chega a elaborar uma classificação metodologicamente mais eficiente das fontes das obrigações.

A maioria dos autores portugueses, por exemplo, limita-se a reproduzir a enumeração das fontes trazida pelo Código Civil de Portugal, no Capítulo II, Título I, do Livro II (artigos $405^{\circ}$ a 510 $)$ : contratos, negócios unilaterais, gestão de negócios, enriquecimento sem causa e responsabilidade civil $^{41}$.

No Brasil, o Código Civil de 2002, da mesma forma que o Código Civil de 1916, não trouxe uma enumeração das fontes. Entretanto, muitos doutrinadores dele extraem - sobretudo, com base nos Títulos do Livro das Obrigações - um rol de fontes. Pode-se mencionar Silvio Rodrigues, que apresenta a seguinte classificação: "a) obrigações que têm por fonte imediata a vontade humana; b) obrigações que têm por fonte imediata $o$ ato ilícito; c) obrigações que têm por fonte direta a lei" ${ }^{\text {"42 }}$. Também Arnold Wald, para quem as fontes das obrigações, no direito brasileiro, são: “os negócios jurídicos (unilaterais e bilaterais), os atos jurídicos lícitos, os atos ilícitos, que abrangem o ato ilícito propriamente dito que gera a responsabilidade civil e o abuso de direito, e a lei",43.

Um exame atento a essas classificações concluirá pela sua insuficiência.

De fato, é difícil estabelecer um rol preciso de fontes das obrigações, porque há um espectro amplo de categorias jurídicas das quais podem nascer obrigações ${ }^{44}$ (fatos jurídicos $^{45}$, situações jurídicas ${ }^{46}$, atividade ${ }^{47}$ ) e, ainda, delas podem advir efeitos jurídicos de outra natureza, que não a obrigacional, fazendo com que a utilidade do instituto fique praticamente esvaziada.

\footnotetext{
${ }^{41}$ LEITÃO, Luís Manuel Teles de Menezes, op. cit., p. 181. Procedem dessa forma: COSTA, Mário Júlio de Almeida, op. cit., p. 177-180; TELLES, Inocêncio Galvão, op. cit., p. 57-58. VARELA, João de Matos Antunes, op. cit., p. 206-211.

${ }^{42}$ RODRIGUES, Silvio, op. cit., p. 10-11.

${ }^{43}$ WALD, Arnold, Direito Civil - Direito das obrigações e teoria geral dos contratos, $19^{a}$ ed., São Paulo, Saraiva, 2010, p. 75-79.

${ }^{44}$ LEITÃO, Luís Manuel Teles de Menezes, op. cit., p. 182.

${ }^{45} \mathrm{Na}$ classificação ponteana dos fatos jurídicos identificam-se: o fato jurídico em sentido estrito, o atofato jurídico, o ato jurídico em sentido estrito e o negócio jurídico, todos possíveis fontes de obrigação. Cf.: Tratado de Direito Privado - Parte Geral - Tomo II - Bens. Fatos Jurídicos, $3^{\text {a }}$ ed., Rio de Janeiro, Borsoi, 1970, p. 183 e seguintes.

${ }_{46}^{46}$ Por exemplo, as situações jurídicas reais da quais podem derivar obrigações propter rem.

${ }^{47}$ Por exemplo, a atividade empresarial.
} 
Todavia, há duas impropriedades que devem ser combatidas:

A primeira delas está em considerar a lei como uma das fontes (imediatas) das obrigações. Foi dito que a lei é sempre fonte mediata das obrigações e aqui cabe explicar, embora sucintamente, esta afirmação.

É esclarecedora a lição de Orlando Gomes. O autor chama atenção para o fato de a expressão fontes das obrigações poder ter dois significados. No primeiro deles, fonte das obrigações - no singular - é tão somente a lei, pois é ela que, necessariamente, confere juridicidade às relações sociais. Nesse sentido, qualquer relação jurídica e não somente a relação obrigacional tem como fonte a lei. No outro significado, fontes das obrigações são os fatos jurídicos ou as situações jurídicas a que a lei atribui o efeito de constituir a obrigação. Assim sendo, o autor distingue a fonte imediata das fontes mediatas das obrigações: aquela, a lei; estas, os fatos ou situações suscetíveis, de acordo com o ordenamento jurídico, de determinarem o nascimento da obrigação ${ }^{48}$.

Diferentemente, do que foi dito, observe que o autor considera a lei fonte imediata das obrigações. Entende-se, contudo, que a lei é, na verdade, fonte mediata, pois a obrigação resulta não diretamente da lei, mas da concreção no mundo fenomênico do fato ou da situação previstos abstratamente por ela.

Com base nestas considerações, evidencia-se, por exemplo, que a fonte imediata da obrigação alimentícia é a situação jurídica do parentesco, do casamento ou da união estável, sendo que a lei, mediatamente, confere-lhes a característica de jurídicas.

A segunda impropriedade se refere ao ato ilícito. Afirma-se, normalmente, que a fonte da obrigação de indenizar é o ato ilícito. Todavia, a fonte da obrigação de indenizar não é o ato ilícito ou, pelo menos, não é só ele. O dever de indenizar só surgirá quando restar caracterizado um dano injusto, que pode ou não resultar de ato ilícito.

Por outro lado, é verdade que o ato ilícito pode dar origem a outras obrigações que não a de indenizar. Para o condômino que infringe deveres de convívio previstos na convenção condominial sem causar dano injusto surgirá obrigação de pagar

\footnotetext{
${ }^{48}$ GOMES, Orlando, op. cit., p. 31-32.
} 
multa pecuniária que lhe for imposta, sem que se possa ver nisso qualquer natureza indenizatória.

Vê-se, portanto que o dano injusto é a verdadeira fonte da obrigação de indenizar, e esta o elemento que dá sentido a toda construção dogmática a respeito da responsabilidade civil. O objetivo próprio da responsabilidade civil não é, dessa forma, estabelecer a relação creditícia e suas garantias - objeto da Teoria Geral das Obrigações -, mas, sim, estabelecer os pressupostos do surgimento da obrigação de indenizar, é dizer, os pressupostos para que um dano seja reputado injusto e, pois, passível de deflagrar a estrutura de responsabilização ${ }^{49}$.

Têm, pois, razão os que, como Menezes Cordeiro, reconhecem que a responsabilidade aquiliana e a obrigacional, porque perseguem valores díspares, sujeitamse a regimes jurídicos bastante diversos ${ }^{50}$.

\footnotetext{
${ }^{49}$ Esta afirmação não significa que o dano injusto não mais é fonte das obrigações, ao contrário. Uma vez deflagrada a estrutura de responsabilização nos moldes fornecidos pela dogmática da responsabilidade civil e, ao final, imputada a alguém a obrigação de indenizar, toda construção da Teoria Geral das Obrigações terá lugar.

${ }^{50}$ Menezes Cordeiro, procurando diferenciar a responsabilidade civil obrigacional da aquiliana, afirma que, em termos genéticos: “A responsabilidade obrigacional está a serviço do valor 'contrato', de que é um lógico prolongamento. Já a responsabilidade civil aquiliana (...) está a serviço do valor 'propriedade' (em sentido amplo, já que não se confina aos direitos reais)”. E continua: “(...) A diferenciação dos regimes aplicáveis a ambas as responsabilidades arranca das clivagens genéticas apontadas. $\mathrm{Na}$ responsabilidade obrigacional há sempre que lidar com a fonte original da obrigação em jogo (matricialmente: um contrato) e com o 'facto ilícito' do seu incumprimento (matricialmente: a não-execução da prestação principal). Ora, para se chegar a este ponto, há todo um conjunto de passos a dar: a interpelação, a cominação de um prazo admonitório ou o desinteresse objectivo superveniente e, depois, a constituição do dever de indemnizar, a articular com a estrutura sobrevivente da obrigação anterior. O ponto de partida é o da constituição da obrigação. Já na aquiliana, bastarão o facto e os demais pressupostos. O momento zero é o da perpetração do facto em causa devendo, a partir daí, constituir-se toda uma relação entre o agente e o lesado". CORDEIRO, António Menezes, Tratado de direito civil português, v. II - Direito das Obrigações, Tomo III - Gestão de negócios, enriquecimento sem causa, responsabilidade civil, Coimbra, Almedina, 2010, p. 390-391. Fazendo coro às lições de Menezes Cordeiro, Manuel A. Carneiro da Frada, Direito Civil - Responsabilidade Civil O método do caso, Coimbra, Almedina, 2006.

É importante salientar que Menezes Cordeiro emprega as expressões responsabilidade civil obrigacional e aquiliana para se referir às espécies de responsabilidade civil que no Brasil são tradicionalmente denominadas responsabilidade civil contratual e extracontratual ou aquiliana, respectivamente. A terminologia utilizada por Menezes Cordeiro é mais adequada, porque na responsabilidade civil obrigacional "está em causa o não-cumprimento de obrigações, independentemente de sua fonte. Quer isso dizer que, num momento prévio, houve uma obrigação com o seu dever de prestar e que este, não tendo sido cumprido, deu azo ao de indemnizar". Ibid., p. 387. Portanto, pode-se afirmar que ela abrange também a responsabilidade proveniente de promessa de recompensa, testamento, gestão de negócios. Por sua vez, a responsabilidade civil extraobrigacional surge como consequência da violação de direitos que aparecem desligados de qualquer relação obrigacional previamente existente entre lesante e lesado.
} 
É partindo desta constatação metodológica que se almeja fixar o pressuposto do dever de indenizar, procurando afastar concepções que, sob o pretexto de modernizar a responsabilidade civil, acabam por turvá-la, dificultando a realização de seu objetivo máximo: a justa indenização da vítima. 


\section{CAPÍTULO 2 - NOTÍCIA HISTÓRICA SOBRE A EVOLUÇÃO DA RESPONSABILIDADE CIVIL NO SISTEMA ROMANO- GERMÂNICO}

\subsection{Nota introdutória}

A breve evolução histórica do instituto analisado tem por objetivo demonstrar a lenta separação que se operou entre a responsabilidade civil e a responsabilidade penal, fazendo com que aquela se estruturasse em torno da ideia de reparação de danos.

\subsection{Das origens ao Corpus Iuris Civilis}

As situações, atualmente, contempladas pelo instituto da responsabilidade civil encontram suas origens na vingança coletiva, forma de reação conjunta, em que os membros do clã do ofendido voltavam-se contra o clã do agressor, desencadeando uma verdadeira guerra entre clãs, da qual resultaria a subjugação do mais fraco ${ }^{51}$.

A evolução tenderia a individualizar a responsabilização, fazendo-a recair tão somente sobre o causador do dano. Houve as primeiras composições entre clãs, que consistiam na entrega do agressor, pelo seu clã, ao clã que teve seus membros ou bens lesionados. Era a entrega - ou o abandono - noxal. Com ela, evitava-se a vingança coletiva $^{52}$.

Essa forma de repressão do dano, em que a vítima reagia contra o mal sofrido, fazendo justiça com as próprias mãos, foi, em seguida, legalizada: cabia à

\footnotetext{
${ }^{51}$ CORDEIRO, António Menezes, op. cit., p. 290-293; GUARINO, Antonio, Diritto privato romano, 12 ${ }^{\mathrm{a}}$ ed., Napoli, Editore Jovene Napoli, 2001, p. 982. BIONDI, Biondo, Instituizioni di Diritto Romano, $2^{\mathrm{a}}$ ed., Milano, s.e., 1952, p. 354-355; GILISSEN, John, Introdução histórica ao direito, $5^{\mathrm{a}}$ ed., tradução de A. M. Hespanha e L. M. Macaísta Malheiros, Lisboa, Fundação Calouste Gulbenkian, 2008, p. 42.

52 CORDEIRO, António Menezes, op. cit., p. 290-293. O autor esclarece que, num primeiro momento, ficava a critério do clã a que pertencia o agressor entregá-lo ao clã do ofendido. Essa, a entrega noxal pura. Mais tarde, reconheceu-se o direito do clã ofendido à entrega do agressor, passando-se, assim, à actio noxalis. Inicialmente, essa entrega atingia qualquer membro do clã. Mais tarde, contudo, como será visto adiante, ficou restrita ao filius familias e ao servus e, finalmente, só ao servus. Ibid., p. 292.
} 
autoridade pública declarar se a vítima era, ou não, titular do direito de retaliação. Isso garantia, de resto, que fosse perpetrado contra o ofensor dano idêntico ao que fora produzido por ele, de modo a não se ultrapassar as consequências do ato ilícito. Esta era a pena de Talião, que inspirou algumas das disposições da Lei das XII Tábuas.

Posteriormente, ocorreu significativa mudança no pensamento dominante. Percebeu-se ser mais vantajoso proceder-se à cobrança de quantia em dinheiro do que se valer da retaliação ${ }^{53}$. Sucedeu, então, o período da composição pecuniária voluntária, em que a vítima, a seu critério, podia entrar em acordo com o autor da ofensa, recebendo deste uma soma em dinheiro como resgate da vindicta.

Mais tarde, a Lei das XII Tábuas ${ }^{54}$ instituiu, para a maioria dos delitos nela tipificados, a obrigatoriedade da composição pecuniária ${ }^{55}$, fixando, inclusive, o quantum da pena a ser aplicada para cada delito nela descrito ${ }^{56}$.

Nesta lei, o recurso ao talião, embora não extinto, passou a ser uma exceção, estando previsto apenas em delitos mais graves, como em casos de furtum manifestum e de membrum ruptum. Contudo, em tais delitos, salvo no furtum manifestum praticado por

\footnotetext{
${ }^{53}$ DIAS, José de Aguiar, op. cit., p. 30.

${ }^{54}$ Essa Lex foi o resultado de um trabalho que durou cerca de três anos (do ano de 451 a.C. ao ano de 449 a.C.), realizado por um colégio de magistrados com poderes legislativos, os decemviri legibus scribundis, que se encarregou de organizar a tradição prática jurídica dos antepassados. $\mathrm{O}$ texto original acabou sendo destruído no ano de 391 a.C., quando Roma foi saqueada e incendiada por tropas celtas sob o comando do general Breno. Por meio de citações e de referências, nem sempre exatas e fidedignas, feitas ao texto pelos juristas romanos e por escritores romanos posteriores, foi possível conhecer o conteúdo da lei decenviral. BETANCOURT, Fernando, Derecho romano clásico, Sevilla, Universidad de Sevilla - Secretariado de Publicações, 2001, p. 44-45.

55 Nas palavras de Max Kaser: "Como na responsabilidade delitual o primitivo direito de vingança se tornou remível na maioria dos casos por pagamento de multa, a idéia de vingança passa a segundo plano. A RESPONSABILIDADE implica agora que alguém se acha submetido com a sua PESSOA a um PODER DE APREENSÃO de outrem, que se pode IMPOR JUDICIALMENTE e do qual ele pode libertar por REMISSÃO”. KASER, Max, Direito privado romano, tradução de Samuel Rodrigues e Ferdinand Hämmerle, revisão de Maria Armanda de Saint-Maurice, Lisboa, Fundação Calouste Gulbekian, 1999, p. 193.

56 Aquele que cortasse abusivamente árvores em terreno alheio podia ser demandado com a actio de arboribus succissis, que impunha uma pena de 25 asses por cada árvore. JUSTO, A. Santos, Direito Privado romano II - Direito das obrigações, in Boletim da Faculdade de Direito da Universidade de Coimbra, Coimbra, Coimbra Editora, 2003, p. 122 e 133. Para o delito de iniuria que não configurasse caso de membrum ruptum, Moreira Alves informa que a Lei das XII Tábuas estabelecia as seguintes penas pecuniárias: "no valor de 300 asses, na hipótese de os fractum, sendo a vítima homem livre; no valor de 150 asses, no caso de os fractum, sendo a vítima escravo; e no valor de 25 asses, quando se tratasse de outras espécies de lesões". ALVES, José Carlos Moreira, Direito romano, v. 2, 4a ed., Rio de Janeiro, Forense, 1986 , p. 276-277.
} 
servus, admitia-se também a composição voluntária. Assim, se a vítima aceitasse receber do ofensor quantia em dinheiro, a pena de talião seria afastada ${ }^{57}$.

Nesse momento, ainda, nos casos em que o delito fosse praticado pelo filius familias ou pelo servus, a noxalidade permitia ao paterfamilias ou ao dominus escolher entre: ser condenado a pagar pena pecuniária à vítima ou, então, abandonar o filho ou o escravo em favor dela (noxae deditio $)^{58}$.

A Lei das XII Tábuas não estabeleceu uma categoria geral e abstrata de delictum (ato ilícito). Nela estavam tipificados alguns delicta, que continham pressupostos

${ }^{57}$ KASER, Max, op. cit., p. 193; ALVES, José Carlos Moreira, op. cit., p. 276-277.

Quanto à pena a ser aplicada ao fur (ladrão) no delito de furtum manifestum (aquele em que o ladrão é surpreendido no momento em que pratica o delito), haveria que se distinguir: se o ladrão fosse homem livre e púbere, ele era açoitado e entregue à vítima - a doutrina não tem certeza se ele era entregue na condição de servus ou de addictus -; se fosse homem livre impúbere, era apenas chicoteado; se fosse servus, era açoitado e precipitado da rocha Tarpeia. Com relação às duas primeiras hipóteses, as penas poderiam ser afastadas se a vítima entrasse em acordo com o fur, que pagaria, assim, a ela uma quantia a título de resgate. Ainda, a Lei das XII Tábuas permitia a morte do fur, caso ele praticasse o furtum à noite, ou caso tentasse defender-se com o uso de arma, mesmo praticando o furtum durante o dia. ALVES, José Carlos Moreira, op. cit., p. 269275. CHAMOUN, Ebert, Instituições de direito romano, $2^{\mathrm{a}}$ ed., Rio de Janeiro, Revista Forense, 1954, p. 392.

Já quanto à hipótese de membrum ruptum, a Lei das XII Tábuas dispunha: "Si membrum rup(s)it ni cum eo pacit, talio est", isto é, ser for mutilado um membro e não se chegar a um acordo, imponha-se ao autor a pena de talião. KASER, Max, op. cit., p. 289. Moreira Alves chama atenção para o fato de não haver um consenso entre os autores modernos sobre o significado de membrum ruptum: “(...) para uns, é a perda ou amputação total de um membro; para outros, qualquer lesão que não seja fratura de osso, pois nesse caso, ocorria os fractum". ALVES, José Carlos Moreira, op. cit., p. 277.

${ }^{58}$ Nesse sentido: Gai. 4, 75. "Ex maleficiis filiorum familias seruorumque, ueluti si furtum fecerint aut iniuriam commiserint, noxales actiones proditae sunt, uti liceret patri dominoue aut litis aestimationem sufferre aut noxae dedere". Em tradução livre: Para os delitos dos filhos ou dos escravos, por exemplo, em caso de furtum ou iniuria, são predispostas as ações noxais, a fim de que seja consentido ao pai, ou ao proprietário (do escravo) ou suportar a condenação ao pagamento de uma soma em dinheiro (litis aestimatio) ou efetuar a noxae deditio.

Quando se abandonava o filho em favor da vítima, ele tornava-se quase-escravo, isto é, pessoa in mancipi. O escravo, por sua vez, passava à propriedade da vítima. Vigia o princípio noxa caput sequitur, segundo o qual a responsabilidade deveria recair sobre o paterfamilias ou o dominus a quem pertencesse o filho ou o escravo quando da propositura da ação penal. Dessa forma, tornando-se o filho sui iuris ou adquirindo o escravo a libertas, teria a vítima que instaurar a ação contra eles.

Cumpre salientar que a noxalidade era uma característica das actiones resultantes dos delicta (actiones poenales) e verificava-se, também, em relação ao proprietário do animal que tivesse causado dano a terceiro. Consistia no seguinte: "se o delito fosse praticado por filius familias ou escravo, com o desconhecimento ou até contra a sua vontade - do pater familias, ou se um seu animal causasse prejuízo a terceiro, a vítima do delito podia intentar a ação penal contra o pater familias, a quem era facultada esta alternativa”. ALVES, José Carlos Moreira, op. cit., p. 267-268. Assim por exemplo, na actio de pauperie (ação dirigida contra o proprietário do animal que danificou coisa alheia) e na actio de pastu pecoris (ação dirigida contra o proprietário do animal que pastou em terreno alheio) conferia-se ao dominus essa faculdade: pagar a pena pecuniária ou entregar o animal à vítima, que se tornava seu proprietário.

O regime da noxalidade persistiu durante a época justinianeia para os escravos e animais, tendo sido abolido para os filii familiae (Inst. 4, 8,7). Permitiu-se, entretanto, que a ação penal fosse proposta diretamente contra o filius familias que tivesse cometido o delito. Cf.: ALVES, José Carlos Moreira, op. cit., p. 265-268; CORREIA, Alexandre, SCIASCIA, Gaetano, Manual de direito romano, v. I, $2^{a}$ ed., São Paulo, Saraiva, 1953, p. 364; JUSTO, A. Santos, op. cit., p. 121. 
próprios, cuja verificação era necessária para que se impusessem as obligationes ali $\operatorname{previstas}^{59}$.

Nesse momento, observa-se grande confusão entre a responsabilidade civil e a responsabilidade penal. A previsão na Lei das XII Tábuas de pagamento de quantia em dinheiro como forma de sanção para atos ilícitos dos quais resultavam prejuízos para a vítima tinha, indiscutivelmente, natureza mais punitiva do que propriamente reparatória. Contudo, deve-se notar que a previsão do mecanismo de composição pecuniária obrigatória para a maior parte dos delitos previstos nessa lei revela um interesse, crescente na evolução histórica, pela reparação dos danos.

Apesar disso, nessa lei já é possível visualizar as duas grandes espécies de responsabilidade civil que a evolução subsequente iria revelar, quais sejam a responsabilidade extraobrigacional e a obrigacional ${ }^{60}$.

A Tábua III continha um procedimento destinado a satisfazer o direito de crédito. Para tanto, fazia-se necessário que houvesse a confissão da dívida pelo devedor ou a sua condenação judicial ao pagamento. Transcorrido o prazo de trinta dias sem que fosse solvida a dívida, haveria a manus iniectio do devedor: este seria conduzido a juízo pelo credor e, caso, nessa oportunidade, não houvesse novamente o pagamento da dívida pelo devedor ou por terceiro, o credor poderia levá-lo para sua casa e mantê-lo preso. Devia, contudo, alimentá-lo. O cárcere privado duraria sessenta dias, durante os quais, o devedor seria levado a três feiras, a fim de que alguém o resgatasse, saldando a dívida. Nesse tempo, o devedor poderia também compor-se com o credor. Findo esse prazo, o credor poderia fazer do devedor seu escravo, vendê-lo fora de Roma (trans Tiberim) ou matá-lo. Nesse último caso, havendo concurso de credores, era possível dividir o corpo do devedor em pedaços proporcionais às dívidas ${ }^{61}$.

\footnotetext{
${ }^{59}$ ALVES, José Carlos Moreira, op. cit., p. 265-268.

${ }^{60}$ CORDEIRO, António Menezes, op. cit., p. 293.

${ }^{61}$ Ibid., p. 297-298. Com a lex poetelia papiria de nexis, de 362 a.C., o devedor deixou de responder com o seu corpo pelas dívidas contraídas. Houve, então, a abolição da escravidão e da morte do devedor. CORDEIRO, António Menezes, Da boa-fé no direito civil, $3^{\text {a }}$ reimpressão, Coimbra, Almedina, 2007, p. 63; SIMÃO, José Fernando, A teoria dualista do vínculo obrigacional e sua aplicação ao direito civil brasileiro, in Direito das obrigações: reflexões no direito material e processual: obra em homenagem a Jones Figueirêdo Alves, coordenadores DE PAULA, Fernanda Pessoa Chuahy; MENEZES, Iure Pedroza; CAMPELLO, Nalva Cristina Barbosa, São Paulo, Método, 2011, p. 239-253.
} 
Foi a lex aquilia de damno ${ }^{62}$ que teve o importante mérito de sedimentar a reparação pecuniária como a sanção a ser imposta ao causador de um dano, expurgando, finalmente, as composições e as práticas taleônicas ${ }^{63}$.

O texto aquiliano continha três capítulos. O primeiro capítulo dispunha que quem matasse um escravo ou animal quadrúpede deveria pagar ao dono o mais alto valor que a res tivesse atingido no ano anterior ao delito. O capítulo segundo previa que o credor acessório (adstipulator), que em fraude contra o credor principal (stipulator), extinguisse indevidamente o crédito com uma acceptilatio $^{64}$, ao invés de exigi-lo, ficava obrigado a pagar o valor da dívida ao credor principal - a relação estabelecida entre esses credores funcionava como um mandatum -. Por sua vez, o capítulo terceiro previa que aquele que tivesse causado danos a um escravo ou a um animal alheio, bem como destruído ou deteriorado coisa corpórea de outrem deveria pagar ao dono o valor máximo que a res teve nos trinta dias subsequentes ao delito ${ }^{65}$.

Com relação ao capítulo segundo, ele caiu em desuso logo na época clássica em virtude do aparecimento da actio mandati ${ }^{66}$.

Os primeiro e terceiro capítulos referiam-se ao damnum iniuria datum, espécie de delito consistente em alguém causar, de maneira culposa, um dano em coisa alheia animada ou inanimada ${ }^{67}$.

A configuração do damnum iniuria datum exigia a presença de três requisitos: (i) a iniuria em sentido amplo, ou seja, era preciso que o ato do qual resultava o

\footnotetext{
${ }^{62}$ A lex aquilia foi um plebiscito, provavelmente do século III a.C., rogado à plebe por Aquilius, tribuno da plebe. Ulp. 18 ad ed., D. 9,2,1: "Quae lex Aquilia plebiscitum est, cum eam Aquilius tribunus plebis a plebe rogaverit". CORDEIRO, António Menezes, Tratado de direito civil português, v. II - Direito das Obrigações, Tomo III - Gestão de negócios, enriquecimento sem causa, responsabilidade civil, Coimbra, Almedina, 2010, p. 295.

${ }^{63}$ CORDEIRO, António Menezes, Tratado de direito civil português, v. II - Direito das Obrigações, Tomo III - Gestão de negócios, enriquecimento sem causa, responsabilidade civil, Coimbra, Almedina, 2010, p. 297.

${ }^{64}$ A acceptilatio era o ato jurídico que extinguia o contrato de stipulatio. Tratava-se de uma formalidade que envolvia a seguinte pergunta do devedor e congruente resposta do credor: "Quod ego tibi promisi habesne acceptum? Habeo". MARKY, Thomas, Curso elementar de direito romano, $8^{\mathrm{a}}$ ed., São Paulo, Saraiva, 1995, p. 146-147.

${ }^{65}$ JUSTO, A. Santos, op. cit., p. 133-134.

${ }^{66}$ As próprias Institutas de Justiniano fazem expressa menção a esse fato: Inst. 4, 3, 12: "Caput secundum legis Aquiliae in usu non est".

${ }^{67}$ ALVES, José Carlos Moreira, op. cit., p. 278.
} 
dano fosse contrário ao direito (ilicitude: in-iuria) - assim, o dano causado à coisa alheia em legítima defesa ou estado de necessidade não era considerado damnum iniuria datum e praticado com dolo (dolus malus) ou com culpa em sentido estrito (negligência) ${ }^{68}$; (ii) um dano corpore corpori datum, isto é, dano produzido diretamente pelo agente e que atingisse materialmente a coisa alheia; (iii) uma conduta comissiva. Não cometia, portanto, o delictum quem causasse dano à coisa alheia por ato omissivo, v.g., deixar o escravo alheio morrer de fome ${ }^{69}$.

Só diante desses três requisitos poderia ser intentada a actio legis Aquiliae pelo dominus da res danificada, que deveria, a princípio, ser cidadão romano ${ }^{70}$. Tratava-se de ação penal, perpétua e noxal, que implicava a condenação in simplum (no valor do prejuízo causado) do ofensor que confessasse ter cometido o dano ou, então, a condenação

\footnotetext{
${ }^{68}$ Max Kaser e Fernando Betancourt asseveram que a lex aquilia de damno exigia que a conduta do autor do delito fosse dolosa. Entretanto, observam que os juristas romanos, ainda ao tempo da República, incluíram na iniuria também a culpa stricto sensu (negligência, imprudência). KASER, Max, op. cit., p. 287-288. BETANCOURT, Fernando, op. cit., p.576. Esse registro é importante porque um dos grandes debates doutrinários travados em relação à Lei Aquilia foi, justamente, o atinente à presença ou não da culpa como requisito essencial à configuração dos delitos nela previstos. Parte da doutrina - von Jhering, Leonardo Colombo, Gaston May - entende que a culpa era elemento indispensável à caracterização do delito. Mas outros estudiosos - Emilio Betti, Mario Cozzi, Mazeuad e Mazeaud - sustentam que a culpa não era elemento constitutivo do delito na lex aquilia, tendo sido introduzida, paulatinamente, por meio das interpretações que foram sendo conferidas ao texto dessa lei, como decorrência das necessidades sociais. Segundo esses autores, o famoso fragmento "in lege Aquilia et levissima culpa venit", atribuído a Ulpiano (Ulp. 42 ad Sab., D. 9, 2, 44 pr.), não passaria de uma mera interpolação. LIMA, Alvino, Culpa e risco, São Paulo, Revista dos Tribunais, 1960, p. 24; DIAS, José de Aguiar, op. cit., p. 49.

O enfrentamento dessa questão não é simples. Para Max Kaser, uma análise dos delicta no direito antigo permite identificar uma tipificação da culpa: a só ocorrência no mundo fático da hipótese descrita no tipo já fazia induzir que houve culpa por parte do agente, de modo que não era preciso perquiri-la. Com o passar dos anos, entretanto, tornou-se necessário provar, em cada caso concreto, que a realização típica se deu com culpa. Op. cit., p. 212-214. O autor afirma: "Em todos os povos, a ÉPOCA PRIMITIVA atém-se à ocorrência exteriormente visível, o acto, e atribui a acção ao agente que produziu o resultado. Também em todo o lado e desde sempre se admite, a partir da experiência, que quem realiza certos actos danosos TÍPICOS, na maioria das vezes quer causar danos; a primitiva RESPONSABILIDADE PELO RESULTADO é, na realidade, uma RESPONSABILIDADE POR CULPA TIPIFICADA. Só com o tempo a questão da culpa é apreciada em cada caso concreto, segundo a vontade individual do agente”. Ibid., p. 213. O autor observa que regra do rei Numa já estabelecia que o parricidium consistia no homicídio doloso de homem livre ("si qui hominem liberum dolo sciens morti duit, paricidas esto”). Na própria Lei das XII Tábuas, alguns delitos continham conceptualmente elementos subjetivos. Era o caso do homicídio causado por imprudência no manejo de arma, do ato descuidado de provocar um incêndio na cidade, e também do furtum e da iniuria (delito consistente na ofensa física e moral feita a uma pessoa). Idem. Especificamente, com relação à lex aquilia, Max Kaser obseva que nela "o fato tem que ser cometido iniuria; isto significava no início não apenas 'ilicitamente' mas também 'dolosamente'. Os juristas da República tardia incluem na iniuria a culpa, uma CULPA que inclui a negligência (...)”. Ibid., 287-288.

${ }^{69}$ CORREIA, Alexandre, SCIASCIA, Gaetano, op. cit., p. 366.

70 A esse respeito, Fernando Betancourt assevera que "la lex Aquilia sólo se refería al propietario ciudadano romano como legitimado activamente a la actio legis Aquiliae. Sin embargo, el Pretor la otorgaba: 1. A los peregrini, com ficción de ciudadanía romana; 2. A los ciudadanos romanos no-propietarios, com ficción de propiedad civil, como por ejemplo, al usufructuario y al titular del fundo dominante em una servidumbre predial rústica”. BETANCOURT, Fernando, op. cit., p.576.
} 
in duplum (no dobro do valor do prejuízo causado), caso o ofensor negasse ter cometido o dano ${ }^{71}$.

É importante salientar que a palavra damnun não era empregada pela lex aquilia, como de resto, inicialmente, pelos romanos, como sinônima de prejuízo, tal qual se entende hoje. Damnun era simplesmente o ataque material a uma coisa, independentemente da ocorrência de um efetivo prejuízo sofrido pelo proprietário ${ }^{72}$.

Foi a partir da lex aquilia de damno e dos trabalhos dos pretores e dos jurisconsultos que se construiu a moderna concepção de responsabilidade civil delitual, também designada aquiliana.

Os estreitos termos da lex aquilia, que acabava não contemplando muitos fatos causadores de danos, fizeram com que a iurisprudentia, por meio de interpretação extensiva e analógica, alargasse seu âmbito de aplicação aos casos de danos non corpore sed corpori; danos causados a não proprietários (possuidor de boa-fé, usufrutuário, usuário, credor pignoratício e locatário); danos causados por conduta omissiva ${ }^{73}$.

Segundo Schipani, os juristas romanos introduziram o elemento culpa na lex aquilia, e, com base nele, alargaram as espécies de danos passíveis de reparação, introduzindo condutas que não estavam tipificadas na lei. Isso abriu espaço para a elaboração paulatina de um princípio geral (culpa est punienda) para regular as situações causadoras de danos não tipificadas expressamente nas leis romanas ${ }^{74}$.

\footnotetext{
${ }^{71}$ JUSTO, A. Santos, op. cit., p. 133-134.

72 MAZEUAD, Henri; MAZEAUD, Léon; TUNC, André, Tratado teórico y práctico de la responsabilidad civil delictual y contractual, tomo I, v. I, Buenos Aires, Ediciones Jurídicas EuropaAmérica, 1961, p. 40.

73 ALVES, José Carlos Moreira, op. cit., p. 278-281.

${ }^{74}$ SCHIPANI, Sandro, apud SANSEVERINO, Paulo de Tarso Vieira, Princípio da reparação integral indenização no Código Civil, São Paulo, Saraiva, 2010, p. 21-22. A respeito da ausência de um princípio geral de responsabilidade civil no direito romano, afirmam os irmãos Mazeaud e André Tunc: "Lo que sorprende desde un comienzo es que no se encuentre, ni en matéria delictual ni en matéria contractual, un texto legal de alcances generales, que establezca el principio de que quien causa un daño a su prójimo, en determinadas condiciones, debe repararlo. Resulta suficiente, para comprenderlo, con recordar cómo y por qué intervino el legislador. Se trataba de ponerle fin a la venganza corporal, de reemplazarla por el pago de una suma de dinero. El legislador consideró, pues, uno por uno, los delitos, a medida que las quejas suscitadas por su reparación le iban llamado la atención; no procedió jamás sino por casos especiales, decidiendo que quien hubiere sufrido tal o cual daño podría exigir ésta o aquella suma. Los jurisconsultos no tardaron em advertir, sin embargo, la insuficiencia de semejante procedimiento, la necesidad de darle a la víctima un recurso incluso en los casos no previstos expresamente por la ley. Por eso se esforzaron por
} 
Em seguida, a influência do pensamento cristão, já durante o reinado de Justiniano, reforçou a tendência de embasar-se a responsabilidade, tanto aquiliana quanto obrigacional, no princípio da culpa ${ }^{75}$.

Ainda com relação à lex aquilia, é importante salientar também que sua aplicação permitiu aos juristas, a partir da solução de casos concretos, começarem a investigar a relação existente entre o ato do agente e o dano causado, portanto, o nexo de causalidade $\mathrm{e}^{76}$.

No Corpus Iuris Civilis os delicta continuaram tipificados.

Já no período clássico, os delitos cingiam-se a duas categorias, quais sejam delitos públicos e delitos privados.

Os delitos públicos, também denominados crimina, eram aqueles delitos que ofendiam a comunidade romana e, para os quais, fixava-se uma poena publica, de natureza corpórea ou pecuniária $^{77}$. Esses delitos são hoje objeto de estudo por parte do Direito Penal Romano.

extender los textos legales menos concretos, por buscar en ellos la consagración de una regla de conjunto. Por ló demás, no lo lograron nunca por completo". Op. cit., p. 39.

${ }^{75}$ KASER, Max, op. cit., p. 217-218. Referindo-se ao direito romano pós-clássico, o autor afirma: "O princípio de que o devedor responde por dolus e culpa pode agora considerar-se regra geral para o critério da responsabilidade. A ambos os conceitos é dado outro sentido, sublinhando-se a marca da RESPONSABILIDADE moral, que não admite qualquer tipificação, antes exige a apreciação individual de cada caso concreto". Ibid., p. 218. Também Volterra, baseando-se em Albanese, afirma que: "En la aplicación de las normas de la lex Aquilia, los juristas romanos (...) llegan a determinar, valorando el comportamiento del agente, el elemento subjetivo del dolo e de la culpa propriamente dicha (...). El elemento del dolus o de la culpa en la realización del acto dañoso, por tanto, pasa a ser un requisito necesario para la existencia del damnum iniuria datum a partir del siglo II, como se hace evidente por el texto de las Instituciones de Gayo. Surge así y se desarolla em los textos de los juristas, a propósito de la lex Aquilia, el concepto de la culpa extracontactual o aquiliana". VOLTERRA, Eduardo, Instituciones de Derecho Privado Romano, traducción, prólogo y notas a la edición española de Jesús Daza Martínez, reimpresión da $1^{\text {a }}$ edición, Madrid - Espanha, Editorial Civitas S.A., 1991, p. 561.

${ }^{76}$ VOLTERRA, Eduardo, op. cit., p. 561. O autor faz referência a uma discussão travada entre os juristas (Ulp. 18 ad ed., D. 9, 2, 11, pr.) acerca do caso em que um barbeiro barbeava um escravo quando foi atingido violentamente no braço por uma bola lançada por jogadores que estavam próximos, o que fez com que a navalha cortasse a garganta do escravo. $\mathrm{O}$ autor relata que Próculo tendia a sustentar que o barbeiro tinha culpa por estar barbeando o escravo em lugar inadequado e perigoso, frequentado por jogadores. Idem.

${ }_{77}$ Dentre esses crimes, eram considerados mais graves o perduellio (a traição a Roma), o parricidium (homicídio) e o incêndio. MEIRA, Silvio Augusto de Bastos, Instituições de Direito Romano, $3^{a}$ ed., São Paulo, Max Limonad, 1968, p. 330. 
Os delitos privados, denominados delicta ou maleficia, consistiam nas lesões cometidas contra as pessoas (lesões corporais - iniuria) ou seus bens. Esses delitos davam origem a obligationes e também a actiones poenales (ações penais) e eram punidos com pena privada pecuniária (poena privata $)^{78}$.

As Institutas de Justiniano ${ }^{79}$ falavam em quatro figuras de delitos privados: furtum, rapina, damnum iniuria datum e iniuria. Por furtum entendia-se o apoderamento fraudulento de uma coisa, com a intenção de obter um lucro, a coisa mesma, ou o seu uso ou a sua posse ${ }^{80}$. A rapina ou roubo consistia na subtração violenta de coisa alheia. $\mathrm{O}$ damnum iniuria datum, supracitado, reportava-se aos danos causados nas coisas animadas ou inanimadas. Por sua vez, a iniuria, no Corpus Iuris Civilis, parece assumir mais aquele seu sentido estrito, isto é, de ofensa física ou moral feita a uma pessoa ${ }^{81}$.

Evidentemente, os romanos conheceram outros atos ilícitos, os quais, no entanto, não eram inicialmente reconhecidos pelo ius civile como fontes de obligationes. No direito clássico, o pretor concedia às vítimas desses delitos actiones in factum - ações penais -, a fim de que pudessem exigir o pagamento de uma poena. No direito pósclássico, com a união do ius civile e do ius honorarium, o termo obligatione passou a designar qualquer espécie de obrigação, de forma que, como já mencionado, nas suas

\footnotetext{
${ }^{78}$ ALVES, José Carlos Moreira, op. cit., p.34-39, 266-267.

${ }^{79}$ Essa capitulação dos delitos já era reconhecida por Gaio nas suas Institutas e também nos Aureorum Libri. Ibid., p. 266 e seguintes.

${ }^{80}$ Essa definição de furto aparece em Paul. 39 ad ed., D. 47, 2, 1, 3: "Furtum est contrectatio rei fraudulosa lucri faciendi gratia vel ipsius rei vel etiam usus eius possessionisve"; e também em Inst. 4, 1, 1: Furtum est contrectatio rei fraudulosa vel ipsius rei vel etiam usus eius possessionisve, quod lege naturali prohibitum est admittere".

${ }^{81}$ ALVES, José Carlos Moreira, ibid., p. 266 e seguintes.

Cf.: Inst. 4, 4, pr. Observe que iniuria foi vocábulo que conheceu diversos significados no direito romano. Conforme apontado, a Lei das XII Tábuas empregava iniuria para designar uma espécie de delictum, aquele consistente na ofensa à integridade física ou moral de uma pessoa. Mas, ainda no período pré-clássico, essa palavra aparece com um sentido amplo, querendo significar ora antijuridicidade ou ilicitude, ora ilicitude e culpa, e até mesmo injustiça. Nesse sentido: Ulp. 56 ad ed., D. 47, 10, 1 pr: Iniuria ex eo dicta est, quod non iure fiat: omne enim, quod non iure fit, iniuria fieri dicitur. Hoc generaliter. Specialiter autem iniuria dicitur contumelia. Interdum iniuriae appellatione damnum culpa datum significatur, ut in lege Aquilia dicere solemus: interdum iniquitatem iniuriam dicimus, nam cum quis inique vel iniuste sententiam dixit, iniuriam ex eo dictam, quod iure et iustitia caret, quasi nom iuriam, contumeliam autem a contemnendo. Em tradução livre: Por isso, chama-se iniuria aquilo que se faz sem direito, porque tudo o que se faz sem direito, diz-se feito com iniuria. Isso de modo geral; porém, especificamente, a iniuria chama-se contumélia. Às vezes, a denominação iniuria significa o dano causado com culpa, como costumamos dizer na Lei Aquilia; outras vezes, chamamos a injustiça iniuria, porque, quando alguém prolata uma sentença iníqua ou injustamente, é dita iniuria, porque carece de direito e de justiça, como se fosse non-juria [não conforme ao direito]; porém, contumélia de contemnere [desprezar].
} 
Institutas, Justiniano apresenta uma classificação quadripartida das fontes das obrigações: o contrato, o quase-contrato, o delito e o quase-delito ${ }^{82}$.

Dentre os quasi delicta as fontes fazem referência a quatro espécies ${ }^{83}$ : iudex qui litem suam fecerit - quando o juiz, sem incorrer em corrupção propriamente dita, sentenciar mal, seja por dolo ou por imprudência, cometendo um grave erro e causando prejuízo a uma parte, ficará obrigado a reparar o dano, conforme uma avaliação equitativa -; effusum et deiectum - se for causado um dano em virtude de derramamento de líquido ou de lançamento de objeto de um edifício, o habitante principal da casa fica obrigado a pagar uma multa à parte lesada -; positum er suspensum - se do fato de haver, em um edifício, colocado ou suspendido um objeto, resultar perigo de dano aos transeuntes, o habitante principal da casa terá de pagar uma multa -; e receptum nautarum, cauponum, stabulariorum - o capitão de navio, os donos de hospedaria ou de estalagem respondem pelos furtos e danos causados às coisas de seus passageiros ou hóspedes ${ }^{84}$.

Como já apontado, dos delicta e dos quasi delicta decorriam actiones poenales. Dentre outras, destacam-se as seguintes características dessas ações ${ }^{85}$ :

a) a intransmissibilidade ativa e passiva: a princípio, as ações penais só podiam ser intentadas pela vítima contra o ofensor, não se transmitindo aos seus herdeiros. Contudo, mais tarde, admitiu-se que os herdeiros da vítima pudessem ir a juízo, salvo se se tratasse de actiones vindictam spirantes (como a actio de iniuria), uma vez que tinham natureza

\footnotetext{
${ }^{82}$ ALVES, José Carlos Moreira, op. cit., p.34-39, 266-267. O autor informa que Gaio, no Liber secundus aureorum, já enquadrava nas fontes das obrigações os atos ilícitos reprimidos pelo pretor no período clássico. Conforme visto no capítulo 1 dessa dissertação, o jurisconsulto teria apresentado uma tripartição das fontes: o contrato, o delito e as várias figuras de causas (Gai. 2 aur., D. 44, 7, 1, pr.). Nas várias figuras de causas (variae causarum figurae), Gaio agrupou os fatos jurídicos geradores de obligationes que não eram tidos como contratos e nem como delitos. São eles: os atos lícitos unilaterais e os atos ilícitos que o ius civile não qualificava como delicta, mas, em relação aos quais, o pretor concedia ação.

${ }^{83}$ Cf.: Gai. 3 aur., D. 44, 7, 5, 4-6 e Inst. 4, 5. Ignora-se o motivo por que apenas esses quatro delitos, dentre todos aqueles que eram sancionados pelo pretor, foram considerados quasi delicta. VOLTERRA, Eduardo, op. cit., p. 563-566. CHAMOUN, Ebert, op. cit., p. 400-401. Esse último autor noticia que para a doutrina francesa do século XIX e também para o Código Civil francês o quase-delito distingue-se do delito porque aquele é cometido culposamente e este, dolosamente. Ibid., p. 400.

${ }^{84}$ ALVES, José Carlos Moreira, op. cit., p.34-39, 282-284. PETIT, Eugène, Tratado elementar de direito romano, tradução de Jorge Luis Custódio Porto, Campinas, Russel, 2003, p. 621-622.

${ }^{85}$ ALVES, José Carlos Moreira, op. cit., p. 265-267-268; CORREIA, Alexandre, SCIASCIA, Gaetano, op. cit., p. 363-364; JUSTO, A. Santos, op. cit., p. 120-122. VOLTERRA, Eduardo, op. cit., p. 550-553.
} 
personalíssima. Também os herdeiros do ofensor puderam ser demandados nos limites do lucro que obtiveram com o ato ilícito;

b) a indivisibilidade: sendo vários os autores, várias seriam as obligationes, de modo que o pagamento efetuado por um dos coautores não extinguia as obligationes dos demais. Com Justiniano, passou a existir solidariedade entre os coautores;

c) a possibilidade de cumulação de actiones: além da ação penal, a vítima podia ingressar com outras ações conexas com o delito, para que houvesse a restituição da coisa ou o ressarcimento dos prejuízos (como as ações pessoais e as reais);

d) a noxalidade ${ }^{86}$;

e) as mulheres e os impúberes não infantes eram responsabilizados pelos delitos que cometessem ${ }^{87}$

f) a captis diminutio não extinguia a ação. Até o escravo que cometesse um delito poderia ser demandado por meio das ações penais, depois de sua manumissão;

g) as ações penais que sancionavam os delitos do ius civile eram perpétuas, já as decorrentes do ius praetorium eram concedidas pelo prazo de um ano, contado do fato delituoso.

Conforme mencionado, aos delitos públicos impunha-se a poena publica e aos delitos privados, a poena privata. A primeira consistia em morte, em castigos corporais ou em multa, revertida em favor do Estado. A segunda consistia no pagamento de determinada quantia, que, no direito clássico, tinha caráter punitivo, assim como a pena pública, porém, no direito justinianeu, assume também a natureza de reparação de dano, muito embora a denominação tenha permanecido a mesma: poena ${ }^{88}$. Nos delitos públicos, a pena era imposta pela autoridade na qualidade de sujeito passivo atingido, ao passo que,

\footnotetext{
${ }^{86}$ A esta característica já foi feita devida menção na nota de rodapé $\mathrm{n}^{\circ} 58$.

${ }^{87}$ Essa afirmação, quanto aos impúberes não infantes ou infantia maiores, deve ser vista cum grano salis. Eugène Petit faz a seguinte consideração: “As únicas pessoas que não se podem obrigar por delito são as que não são responsáveis por seus atos. São, primeiro, os loucos: não se obrigam por seus delitos a não ser que tenham agido em um momento lúcido; depois, os impúberes na infância, cuja inteligência não está ainda desenvolvida. Quanto aos que tinham saído da infância, mas que não eram púberes ainda, avaliava-se no ato o desenvolvimento de suas faculdades. Somente se obrigavam aqueles que, por sua razão, aproximavam-se da puberdade, pubertati proximi. Os outros, infantiae proximi, não eram mais responsáveis que os infantes (Gaio, III, § 208)”. PETIT, Eugène, op. cit., p. 607.

${ }^{88}$ ALVES, José Carlos Moreira, op. cit., p. 265-266. Isso significa que no direito justinianeu passa haver confusão em relação à função da pena privada: se punitiva, ou se ressarcitória.
} 
quanto aos delitos privados, a autoridade intervinha tão somente para fixar a composição, evitando os conflitos ${ }^{89}$.

Importante, contudo, registrar que o caráter reparatório de prejuízos já era conhecido pelos romanos antes mesmo do direito justinianeu. Ao lado das actiones poenales, havia também as chamadas actiones rem persequentes ou reipersecutórias, que conferiam ao seu autor "o ressarcimento de um dano, ou a restituição daquilo com que o réu indevidamente se enriqueceu" $"$.

Em que pesem essas importantes conquistas alcançadas pelo direito romano, não houve aqui, como se observa, a separação entre responsabilidade civil e responsabilidade penal. Esta divisão só teve lugar com a sistematização desses institutos, conseguida muitos séculos mais tarde, já na época moderna.

\subsection{O Direito intermédio e o moderno}

No início da Idade Média, a invasão do Império Romano do Ocidente pelos bárbaros acarretou um retrocesso em matéria de responsabilidade civil.

Os povos germânicos pouco sabiam sobre responsabilidade individual. Adotavam, no geral, a vingança privada, naquele sistema de solidariedade ativa e passiva do grupo familiar: a lesão a um membro do grupo faz com que a vingança seja perseguida por todo o grupo do qual faz parte, da mesma forma que o ato de um membro do grupo compromete todo o grupo. Também não distinguiam a obrigação contratual da delitual, de modo que o inadimplemento de uma ou outra produzia os mesmos efeitos ${ }^{91}$.

A invasão bárbara impediu a vigência do direito justinianeu na Europa Ocidental $^{92}$. Era aplicado, contudo, o direito pré-justinianeu, contido principalmente no

\footnotetext{
${ }^{89}$ DIAS, José de Aguiar, op. cit., p. 31.

${ }^{90}$ ALVES, José Carlos Moreira, Direito romano, v. 1, $7^{\mathrm{a}}$ ed., Rio de Janeiro, Forense, 1990, p. 293.

${ }^{91}$ GILISSEN, John, op. cit., p. 751-752.

92 Rubens Limongi França informa que: "Particularmente, no referente ao direito ibérico, basta assinalar que as coletâneas justinianeias só vieram a ser conhecidas e a exercer influência no sistema jurídico após a Reconquista". Responsabilidade aquiliana e suas raízes, in Responsabilidade civil - doutrina e jurisprudência, coordenador CAHALI, Yusef Said, São Paulo, Saraiva, 1984, p. 235-255.
} 
Código Teodosiano, em compilações e nas obras de juristas da época clássica que tinham força de lei. É que a adoção pelos povos germânicos do princípio da personalidade do direito - segundo o qual cada indivíduo deve estar sempre sujeito às leis da sua etnia ou tribo, independentemente do lugar onde se encontre - permitiu a coexistência de dois sistemas jurídicos: o direito germânico (leges barbarorum), compilado a partir do século $\mathrm{V}$, essencialmente consuetudinário, aplicado aos povos germânicos; e o denominado direito romano-germânico (leges romanae), uma compilação daquelas normas supracitadas aplicadas às populações romanas ${ }^{93}$.

Destaque deve ser dado ao reino dos visigodos ${ }^{94}$, que se revelou como a mais rica civilização germânica. Este reino unificou aqueles sistemas de direito através da promulgação do Código Visigótico (Lex Gothorum, Liber Iudiciorum, Forum Iudicium ou Fuero Jusgo) no ano de 654, sob o reinado de Recesvindo. Esse diploma, aplicado não só às populações visigóticas, mas também às romanas, tornou-se a base do direito que esteve em vigor na península ibérica até, aproximadamente, o ano de 1260 . Isso porque entre 1256 e 1265 foram redigidas e promulgadas as Siete Partidas, originalmente denominadas de Libro de las Leyes, as quais, por sua vez, vigoraram em Portugal até o século XV e em Espanha até o século XIX ${ }^{95}$.

No Livro VIII, intitulado "De inlatis violentis et damnis" (Acerca dos atos violentos e dos danos), o Código Visigótico tratava, em inúmeras disposições, da responsabilidade aquiliana, numa abordagem diversificada, com alusões aos ensinamentos de Gaio e a outras obras pré-justinianeias. No entanto, o fez ainda sem uma sistematização, não trazendo avanços técnicos à matéria ${ }^{96}$.

Já nas Siete Partidas, o tratamento conferido à matéria, segundo Rubens Limongi França, reveste-se, em alguns aspectos, de um certo caráter científico, como

93 VOGEL, Carlos Alfredo, Historia del derecho romano - desde sus origenes hasta la epoca contemporanea, $3^{\mathrm{a}}$ ed., Buenos Aires, Editorial Perrot, 1957, p. 299-304. GILISSEN, John, op. cit., p. 167172.

${ }^{94} \mathrm{O}$ reino dos visigodos estava localizado na península ibérica e no sudoeste da Gália. GILISSEN, John, op. cit., p. 165.

${ }^{95}$ FRANÇA, Rubens Limongi, op. cit., p. 252.

96 GILISSEN, John, op. cit., p. 185; FRANÇA, Rubens Limongi, op. cit., p. 252. Esse último autor destaca as seguintes rubricas: "De los cometedores e dos forzadores"; "De las quemas e de los quemadores"; "De los damnos de los árboles..."; "Del damno que foce el ganado e de las otras animalias"; "De los puercos que jacen e de las animalias que andan erradas"; "De las abeyas e del damno que facen". Idem. 
ocorre, por exemplo, com o conceito e a classificação dos danos, descritos na Partida Sétima, a qual versa sobre delitos e procedimento penal ${ }^{97}$.

A partir do século XII, começa a desenvolver-se na seara do direito penal a responsabilidade individual: a punição, consistente na aplicação de penas corporais ou multa, passa a recair tão somente sobre o autor do delito. Entretanto, o sistema de responsabilidade coletiva é dominante ainda na Europa Ocidental até o final da Idade Média. Só a partir daí esse sistema vai aos poucos desaparecendo, embora se encontrem resquícios seus até no século XVII ${ }^{98}$.

Progressos mais significativos foram alcançados com a doutrina do jusnaturalismo-racionalista, já nos séculos XVII e XVIII ${ }^{99}$. A responsabilidade civil foi aqui trabalhada a partir de seus quadros gerais, o que permitiu a pesquisa dos seus pressupostos, bem como dos seus fundamentos - algo, por um lado, muito distinto do que fazia o antigo direito romano, que se valia de delitos típicos de pressupostos variáveis, e, por outro lado, semelhante ao que faz o pensamento sistemático ${ }^{100}$.

97 FRANÇA, Rubens Limongi, op. cit., p. 252. O autor reproduz a seguinte passagem, que, ora, transcreve-se diretamente da fonte: "Daño es empeoramiento o menofcabo, o deftruymiento q̃ ome refcibe em fi mefmo, o en fus cofas por culpa de otro. E fon del tres maneras. La primera es quando fe empeora la cofa por algũa otra q̃l mezclã, o por otro mal q̃l fazẽ. La fegunda, quando fe mẽgua por razõ del daño que fazen en ella. La tercera es, quando por el daño fe pierde, o fe deftruye la cofa del todo". Las Siete Partidas del sabio Rey don Alonso el nono: nuevamente glosadas por el Licenciado Gregorio Lopez del Consejo Real de Indias de sua Magestad, Madrid, Boletim Oficial Del Estado, 1974, Setena Partida, Título XV - "De los daños que los omes, o las beftias fazen em las cofas de otro de qual natura quier que fean”, p. 56.

${ }^{98}$ GILISSEN, John, op. cit., p. 752.

${ }^{99}$ CORDEIRO, António Menezes, p. 311-315.

Jacques Henriot informa que foi nesse período que surgiu o substantivo responsabilité. Ele é encontrado no Dictionnaire critique de la langue française, publicado em 1787-1788, em Marseille, pelo abade JeanFrançois Féraud. A Academia francesa admitiu a palavra responsabilité em 1798, quando ela apareceu no Dictionnaire général de la langue française. O adjetivo responsable, contudo, aparecera anteriormente, por volta de 1300. HENRIOT, Jacques, Note sur la date et le sens de l'apparition du mot "responsabilité", in Archives de philosophie du droit, n. 22, 1977, p. 59-62.

${ }^{100}$ CORDEIRO, António Menezes, op. cit., p. 311-315. Fazendo menção a alguns dos representantes da Escola do Direito Natural e aos seus estudos sobre responsabilidade civil, Menezes Cordeiro observa que em Grócio (1583-1645) o sistema de responsabilidade delitual está verdadeiramente assentado na culpa, de tal forma que ela é tida como um pressuposto absorvente dos demais. Esse autor chega mesmo a rejeitar a responsabilização por ato de terceiros. Com Pufendorf (1632-1694) surge o conceito de imputatio, o qual pressupõe a imputativitas, de modo que, se falta ao agente liberdade ou discernimento, não haverá que lhe imputar a responsabilização pela conduta (ação ou omissão). Em Christian Thomasius (1655-1754) aparece já uma profunda distinção entre os conceitos de culpa e ilicitude. Ibid., p. 311-315. Jean Domat (1625-1696) introduz o conceito de faute, palavra que foi mais tarde incorporada ao artigo 1.382 do Código Napoleão, artigo esse que encerra a cláusula geral da responsabilidade civil no ordenamento jurídico francês. A faute "surge, numa notável síntese, como fundamento evidente da responsabilidade e como instrumento dogmático da sua concretização". Ibid., p. 321-325. 


\subsubsection{As codificações francesa e alemã}

O Code Civil de 1804 e o BGB de 1900 acabaram consagrando dois sistemas distintos de responsabilidade civil.

O legislador francês criou um sistema simplificado e muito funcional, conseguindo aplicações ilimitadas ${ }^{101}$. Esse êxito deve-se basicamente à indefinição da palavra faute prevista no artigo 1.382, a qual tem um sentido objetivo (infração a padrões de comportamento), e um outro subjetivo (relacionado à capacidade individual do agente; censura moral imputável ao autor) ${ }^{102}$. A doutrina afirma que na faute estavam abrangidos os pressupostos da conduta, da ilicitude, da imputabilidade e até do nexo causal ${ }^{103}$. Assim, era suficiente a faute e um dano para que surgisse o dever de indenizar ${ }^{104}$. Nos termos do artigo 1.149, esta indenização deveria corresponder ao integral prejuízo sofrido pela vítima.

O sistema germânico, por sua vez, acolheu pressupostos de imputação autonomizados e estabeleceu cláusulas parcelares de responsabilização ${ }^{105}$, como a do $§ 823$, I, que estabelece o dever de indenizar os danos causados pela violação culposa de determinados direitos subjetivos, como a vida, a liberdade, a propriedade; a do §823, II, que prevê o dever de indenizar os danos decorrentes da violação de normas destinadas à proteção de outrem; e a do $\S 826$, que determina o dever de indenizar os danos causados por ato que, dolosamente, atente contra os bons costumes.

Opções dogmáticas e de política legislativa justificam a contraposição desses sistemas de responsabilidade civil $^{106}$. Contudo, neles há um ponto comum inegável: a ideia na qual se assentam é a reparação de danos.

\footnotetext{
${ }^{101}$ CORDEIRO, António Menezes, op. cit., p.322 e seguintes.

102 DIAS, José de Aguiar, op. cit., p. 51-52.

${ }^{103}$ CORDEIRO, António Menezes, op. cit., p. 322 e seguintes.

${ }^{104}$ CORDEIRO, António Menezes, ibid., p. 445.

${ }^{105}$ CORDEIRO, António Menezes, Da boa-fé no direito civil, $3^{\mathrm{a}}$ reimpressão, Coimbra, Almedina, 2007 , p. 564-571; Tratado de direito civil português, v. II - Direito das Obrigações, Tomo III - Gestão de negócios, enriquecimento sem causa, responsabilidade civil, Coimbra, Almedina, 2010, p. 335-341.

${ }^{106}$ CORDEIRO, António Menezes, Tratado de direito civil português, v. II - Direito das Obrigações, Tomo III - Gestão de negócios, enriquecimento sem causa, responsabilidade civil, Coimbra, Almedina, 2010, p.332. Este autor observa que, quanto às considerações dogmáticas, "pesou a necessidade de se uniformizar a linguagem e de dar corpo à clarificação de Jhering entreaberta por Savigny" (para Jhering, a responsabilidade civil exige, além da ilicitude, a imputabilidade do agente); quanto ao motivo político,
} 
O trabalho da doutrina e da jurisprudência posteriores a essas codificações permitiu que, no sistema romano-germânico, se operasse uma rígida cisão entre responsabilidade civil e responsabilidade penal: aquela voltada à reparação de danos; esta, à punição pelo cometimento de crimes.

\subsubsection{O direito brasileiro}

A história do direito brasileiro até o início do século XIX é a história do direito português. Apenas com a proclamação da independência, em 1822, pode-se falar em um direito propriamente brasileiro.

Com relação ao direito civil, as Ordenações Filipinas permaneceram em vigor até a vigência do Código Civil de 1916. Nelas, o tema da responsabilidade civil praticamente não aparece. Alguma disposição é prevista em matéria de responsabilidade contratual, no Livro IV ${ }^{107}$.

Em 1830, com a entrada em vigor do Código Criminal, foram introduzidas regras para a fixação do montante de indenização devido em razão da causação de danos. Este Código, na sua Parte Primeira (Dos Crimes, e das Penas), Título I (Dos Crimes), Capítulo IV (Da Satisfação), continha dispositivos referentes à satisfação dos danos causados pelo criminoso com a prática do delito. O artigo 22, que configurava uma regra geral, estabelecia que: “A satisfação será sempre a mais completa, que fôr possivel, sendo no caso de duvida á favor do offendido. Para este fim o mal, que resultar á pessoa, e bens do offendido, será avaliado em todas as suas partes, e consequencias".

Por sua vez, no Título II (Das Penas), o Código Criminal trazia dispositivos gerais sobre as penas a serem impostas pela prática de delitos.

\footnotetext{
"vingou a necessidade de restringir o âmbito da responsabilidade civil. O BGB foi aprontado, já sob a Revolução Industrial, numa ocasião em que, sectorialmente, se ia impondo a responsabilidade objetiva. $\mathrm{O}$ legislador optou pela prudência: a multiplicação das situações de imputação iria coarctar os empreendimentos, pela multiplicação dos riscos”. Ibid., p. 332-333.

${ }^{107}$ CORDEIRO, António Menezes, op. cit., p.353-354. O autor explica que esse "relativo silêncio das Ordenações", em matéria de responsabilidade civil, deve-se ao fato de que "toda a matéria delitual constava do corpus iuris civilis e do Direito comum, vigentes em Portugal”. Idem.
} 
Essa divisão feita pelo Código Criminal de 1830 entre "satisfação" e "penas" revela que o legislador já tinha clareza da distinção entre as naturezas jurídicas indenizatória (de danos) e punitiva (de delitos). Com o Código Civil de 1916, essa divisão, finalmente, se opera de forma sistemática no ordenamento jurídico brasileiro ${ }^{108}$.

${ }^{108}$ O modelo de responsabilidade civil adotado pelo Código Civil de 1916, no geral, era muito próximo ao do Code Civil francês. O diploma brasileiro em seu artigo 159 trazia uma cláusula geral de responsabilidade civil tal qual a prevista no artigo 1.382 do Código Napoleão. Com relação à indenização devida em casos de lesão corporal e homicídio, o Código de 1916 continha dispositivos específicos (artigos 1.537, 1.538 e 1.539), o que demonstra inspiração no direito alemão. Essa opção do Código Civil de 1916 foi seguida in totum pelo Código Civil de 2002. 


\section{CAPÍTULO 3 - ESTRUTURA DA RESPONSABILIDADE CIVIL}

\subsection{Pressupostos da responsabilidade civil}

Do ponto de vista analítico-dogmático, a estrutura da responsabilidade civil refere-se ao conjunto de elementos que devem estar presentes para que surja o dever de indenizar.

A enumeração desses pressupostos é assunto de muita divergência na doutrina dos diversos ordenamentos jurídicos.

Em Portugal, por exemplo, Pessoa Jorge aponta: “o acto ilícito e o prejuízo reparável"109. Antunes Varela elenca: o facto (controlável pela vontade do homem), a ilicitude, a imputação do facto ao lesante, o dano, um nexo de causalidade entre o facto e o dano $^{110}$.

No Brasil, Agostinho Alvim, refere a prejuízo, culpa e nexo casual ${ }^{111}$. Silvio Rodrigues indica: a ação ou omissão do agente, a culpa do agente, a relação de causalidade e o dano experimentado pela vítima ${ }^{112}$. Fernando Noronha, por sua vez, fala em dano, cabimento do dano no âmbito de proteção de uma norma, fato antijurídico, nexo de causalidade e nexo de imputação ${ }^{113}$.

Esse trabalho adotará a tripartição conduta, dano e nexo de causalidade. Trata-se de uma estrutura simplificada, contudo, como se verá ao longo desse capítulo, aplicável a toda e qualquer forma de responsabilidade civil.

\footnotetext{
109 JORGE, Fernando de Sandy Lopes Pessoa, Ensaio sobre os pressupostos da responsabilidade civil, Lisboa, Centro de Estudos Fiscais da Direcção-Gerral das Contribuições e impostos - Ministério das Finanças, 1972, p. 55-56.

${ }^{110}$ VARELA, João de Matos Antunes, op. cit., p. 525 e seguintes.

111 ALVIM, Agostinho, Da inexecução das obrigações e suas consequências, $2^{\mathrm{a}}$ ed., São Paulo, Saraiva, 1955, p. 194.

${ }^{112}$ RODRIGUES, Silvio, Direito Civil-Responsabilidade civil, v. 4, $20^{\text {a }}$ ed., São Paulo, Saraiva, 2003, p. 14-18.

${ }^{113}$ NORONHA, Fernando, Direito das obrigações - fundamentos do direito das obrigações - introdução à responsabilidade civil, v. 1, 2ª ed. rev. e atual., São Paulo, Saraiva, 2007, p. 466-469.
} 


\subsection{Conduta}

Como ponto de partida para a análise desse pressuposto da responsabilidade civil, coloca-se, inevitavelmente, a seguinte indagação: que o direito, e não só o direito civil, entende por conduta?

Em sentido amplíssimo, Nicola Abbagnano conceitua conduta como:

"Toda resposta do organismo vivo a um estímulo que seja objetivamente observável, ainda que não tenha caráter de uniformidade no sentido de que varia ou pode variar diante de determinada situação" ${ }^{114}$.

O Direito, como é sabido, ocupa-se de condutas humanas, afinal pressupõe o homem em sociedade.

Para o Direito, a conduta humana que interessa é aquela resultante de um estímulo necessariamente iniciado ou avaliado na psique do agente.

Um estímulo externo só produzirá conduta jurídica se a psique do agente estimulado impulsioná-lo - impulso encarado como processo de decisão - a fazer ou deixar de fazer algo.

Aquele que sofre uma agressão, por exemplo, tapa no rosto, a recebe como um estímulo externo. A partir desse momento a sua psique o impulsionará a adotar uma de um sem-número de condutas possíveis, como revidar, procurar o Estado, oferecer a outra face ou simplesmente quedar-se inerte.

Hipótese diversa apresenta-se quando alguém sofre um estímulo externo imune a qualquer comando da psique, por exemplo, alguém que seja empurrado por uma multidão e perceba que sob seu corpo alguém é pressionado.

${ }^{114}$ ABBAGNANO, Nicola, Dicionário de filosofia, $5^{\mathrm{a}}$ ed., tradução da $1^{\mathrm{a}}$ edição brasileira coordenada e revista por Alfredo Bossi, revisão da tradução e tradução dos novos textos Ivone Castilho Benedetti, São Paulo, Martins Fontes, 2007, verbete "conduta", p. 203. 
Destarte, para o Direito, conduta é somente a ação ou omissão impulsionada pela psique ou, como se convencionou dizer, somente a ação ou omissão voluntária ${ }^{115}$.

A voluntariedade da conduta significa tão somente participação decisiva da psique humana para a ocorrência do evento avaliado.

Disso decorrem duas importantes considerações.

A primeira diz respeito às chamadas condutas humanas avolitivas. O conceito de conduta trazido acima não permite, sem contradictio in terminis, que se fale em conduta avolitiva. Se for conduta, então há de ser volitiva ${ }^{116}$.

Quando a doutrina faz menção à categoria dos atos-fatos jurídicos, dizendoos possivelmente despidos de vontade, refere-se à vontade de ver realizados certos efeitos, e não à vontade consistente em pôr em marcha um comportamento. A questão dos atosfatos jurídicos é de incidência normativa, isto é, a norma descreve abstratamente um evento - e suas consequências fáticas - necessariamente levado a efeito por um ser humano, sem dar relevância à intenção dele de alcançar, ou não, aqueles efeitos normativa e abstratamente descritos. Daí dizer-se que a norma recebe aquela conduta como se fora avolitiva.

A segunda consideração é a atinente à conduta das crianças e dos deficientes mentais. Quando alguns autores ${ }^{117}$ afirmam que crianças e deficientes mentais não

\footnotetext{
115 No Direito Penal, que, indubitavelmente, é o ramo do Direito que mais se dedicou ao estudo da conduta, elemento que primeiro integra o fato típico, as diversas escolas de pensamento - causalista, neokantista, finalista, social da ação, funcionalista - dão à conduta distintos conceitos. Entretanto, pode-se identificar em todos eles um denominador comum: a voluntariedade. Cf. PRADO, Luiz Regis, Curso de Direito Penal Brasileiro - Parte Geral - arts. $1^{o}$ a 120, v. 1, $5^{\text {a }}$ ed. revista, São Paulo, Editora Revista dos Tribunais, 2005, p. 97-121.

116 Adota-se aqui um conceito estrito de conduta humana, diferentemente do que costuma fazer a doutrina. Pontes de Miranda e Lourival Vilanova, para citar alguns autores, falam em conduta humana volitiva ou avolitiva. Cf.: PONTES DE MIRANDA, Francisco Cavalcanti, Tratado de Direito Privado Parte Geral - Tomo I - Introdução. Pessoas físicas e jurídicas, $3^{\mathrm{a}}$ ed., Rio de Janeiro, Borsoi, 1970; Tratado de Direito Privado - Parte Geral - Tomo II - Bens. Fatos Jurídicos, $3^{\text {a }}$ ed., Rio de Janeiro, Borsoi, 1970. VILANOVA, Lourival, Causalidade e relação no direito, $4^{\mathrm{a}}$ ed. revista, atualizada e ampliada, São Paulo, Editora revista dos Tribunais, 2000.

${ }^{117}$ Por exemplo, Miguel Reale Júnior, Parte geral do Código Penal (nova interpretação), São Paulo, Editora Revista dos Tribunais, 1988.
} 
realizam conduta não percebem a diferença sutil, porém fundamental, entre ausência de participação da psique e formação deficiente do processo mental deliberativo ${ }^{118}$.

O sadio processo mental deliberativo exige pressupostos negativos, vale dizer, pressupõe ausência de causas capazes de tolher ou mitigar a capacidade do agente de avaliar circunstâncias relevantes, causas estas descritas no sistema jurídico, tais como as incapacidades e a coação moral irresistível.

A presença destas causas não elimina a existência de conduta, apenas influencia aspecto posterior a ela, a saber, a imputação dos efeitos causados.

Se, por exemplo, a um cavalo não se imputam as consequências de um evento fisicamente levado a efeito por ele, assim como se pode não as imputar a um ser humano, as razões para tanto são absolutamente distintas ${ }^{119}$. Ao animal não se imputam consequências, porque o sistema jurídico não o elegeu como sujeito de deveres e direitos. Já quando se deixa de imputar consequências a um ser humano, o sistema jurídico, por razões que elegeu, está afirmando que ele tem o direito de não sofrer tal imputação ${ }^{120}$. A distinção é óbvia e carece de qualquer aprofundamento, razão pela qual se passará ao estudo dos elementos da conduta.

\footnotetext{
${ }^{118}$ A afirmação segundo a qual o incapaz não tem vontade e, portanto, não pratica conduta humana parece equivocada, porque desconsidera que as criações jurídicas devem respeitar limites ônticos, isto é, devem contar com respaldo fático mínimo - afinal, o direito é fato-valor-norma, na colocação de Miguel Reale (Teoria tridimensional do direito: preliminares históricas e sistemáticas, $3^{\mathrm{a}}$ ed. revista e atualizada, São Paulo, Saraiva, 1980).

${ }^{119}$ É vicio lógico consistente na antecipação do consequente, a partir da identidade de efeitos, concluir pela identidade da causa.

${ }^{120}$ Oportuno aqui o registro feito por José Fernando Simão: “(...) a responsabilidade civil do próprio incapaz era desconhecida do Direito Romano. As fontes romanas aprovaram a irresponsabilidade do indivíduo privado de razão pelo fato danoso cometido. É a famosa passagem de Ulpiano, comparando o dano ocasionado pelo furious ou pelo infans com o causado por um quadrúpede ou a queda de uma telha: 'Et ideo quarimus, si furiosus damnum derit, na legis Aquiliae actio sit? Et Pegasus negavit: quae enim in eo culpa sit, cum suae mentis non sit? Et hoc est verissimum: cessabit igitur Aquilia action, quemadmodum si quadrupes dederit aut sit tegula ceciderit. Sed et si ifans damnum dederit idem erit dicedum' (D. 9, 2, 2, 5) (ANTUNES, Henrique Sousa. Responsabilidade civil dos obrigados..., p. 291). A crítica que se fazia à comparação de Ulpiano entre o ato do louco e do menor e o dano causado por uma telha ou por um animal é óbvia. Enquanto a telha e o animal não têm personalidade jurídica, e portanto, nem patrimônio, o menor e o louco tinham a chamada capacidade de direito e um patrimônio que poderia arcar com as dívidas". SIMÃO, José Fernando, Responsabilidade civil do incapaz, São Paulo, Atlas, 2008, p. 84, n.r. 5.
} 


\subsubsection{Ação: ato e atividade}

Como já afirmado, a conduta pode ser por ação ou omissão.

Dá-se a ação quando um agente é causa eficiente de um movimento, chamado ato. Este ato, ou conduta comissiva, poderá, ou não, ser relevante para o sistema jurídico conforme seja, ou não, elemento de suporte fático de alguma regra jurídica.

Assim, diante da infinidade de atos possíveis, só serão condutas juridicamente relevantes aqueles previstos abstratamente como tais em normas jurídicas. A existência e qualificação jurídica de uma conduta dependem fundamentalmente da qualidade da norma jurídica que lhe servirá de referencial.

Explica-se: o ato de banhar-se é inegavelmente uma conduta, a qual, no entanto, por não estar abrangida abstratamente em qualquer norma, é inexistente para o direito. $\mathrm{O}$ ato de, dirigindo culposamente, colidir com um veículo causando-lhe avaria material é conduta irrelevante (inexistente) para fins de tipificação penal, mas relevante para fins de responsabilização civil. Já o simples ato de dirigir embriagado é absolutamente irrelevante para fins de responsabilidade civil, mas relevante para fins de eventual responsabilização administrativa junto a órgãos de controle do trânsito e também para fins de tipificação penal.

Então, o ato no mundo fenomênico é pressuposto da conduta juridicamente relevante, a qual será qualificada de acordo com a descrição abstrata da norma jurídica que incidiu concretamente sobre aquele.

O Código Civil de 2002, como já havia feito o Código de Proteção e Defesa do Consumidor ${ }^{121}$, incluiu a atividade como suporte fático de duas de suas normas: o parágrafo único do artigo $927^{122}$ e o caput do artigo $966^{123}$.

121 “Art. $3^{\circ}$ Fornecedor é toda pessoa física ou jurídica, pública ou privada, nacional ou estrangeira, bem como os entes despersonalizados, que desenvolvem atividade de produção, montagem, criação, construção, transformação, importação, exportação, distribuição ou comercialização de produtos ou prestação de serviços".

${ }_{122}$ “Art. 927. (...). Parágrafo único. Haverá obrigação de reparar o dano, independentemente de culpa, nos casos especificados em lei, ou quando a atividade normalmente desenvolvida pelo autor do dano implicar, por sua natureza, risco para os direitos de outrem". 
Ao estabelecer a possibilidade de conduta não por simples ato, mas por atividade, o sistema normativo torna-se mais complexo e, consequentemente, a dogmática jurídica também. Relativamente a esta, porque se impõe aos intérpretes a elaboração de conceito de atividade apto a permitir sua efetivação no mundo fenomênico, destino de toda norma.

Na busca por um conceito operacional de atividade, ganham relevância os esforços dos comercialistas, pois foi principalmente na seara do Direito Comercial que a ideia de atividade como elemento jurídico surgiu e desenvolveu-se.

Tullio Ascarelli, em dois textos clássicos ${ }^{124}$, dedicou-se a traçar os limites dogmáticos do conceito de atividade. Para esse autor, "a atividade não significa ato, mas uma série de atos coordenáveis entre si, em função de um fim comum" ${ }^{25}$.

A partir desta conceituação, Tullio Ascarelli faz derivar consequências fundamentais à correta noção de atividade, entre as quais, destacam-se o fato de a atividade dever ser apreciada de modo autônomo, sem considerar-se os atos que a formam; a necessidade de apreciar-se a atividade a partir de sua finalidade; e, finalmente, ser a atividade efetivamente exercida um fato para cuja existência é irrelevante a vontade do sujeito agente ${ }^{126}$.

A caracterização da atividade exige, pois, não só pluralidade de atos, mas que estes atos estejam teleologicamente unidos e dirigidos, sendo certo que somente com a consideração do elemento finalístico poderá cogitar-se de atividade em sentido técnico.

Portanto, parece que o conceito de atividade proposto por Ascarelli e adotado por muitos doutrinadores ${ }^{127}$ requer a menção a um fator prévio fundamental a

\footnotetext{
123 “Art. 966. Considera-se empresário quem exerce profissionalmente atividade econômica organizada para a produção ou a circulação de bens ou de serviços".

124 ASCARELLI, Tullio, O empresário, tradução de Fábio Konder Comparato, in Revista de Direito Mercantil, Industrial, Econômico e Financeiro, v. 36, n. 109, São Paulo, jan./mar. 1998, p. 183-189; A atividade do empresário, tradução de Erasmo Valladão Azevedo e Novaes França, in Revista de Direito Mercantil, Industrial, Econômico e Financeiro, v. 42, n. 132, São Paulo, out./dez. 2003, p. 203-215.

${ }^{125}$ ASCARELLI, Tullio, O empresário, tradução de Fábio Konder Comparato, in Revista de Direito Mercantil, Industrial, Econômico e Financeiro, v. 36, n. 109, São Paulo, jan./mar. 1998, p. 183.

126 Idem.

${ }^{127}$ Por exemplo, Fábio Konder Comparato e Calixto Salomão Filho, O poder de controle na sociedade anônima, 5 ${ }^{\mathrm{a}}$ ed., Rio de Janeiro, Forense, 2008; Raquel Sztajn, Teoria jurídica da empresa: atividade
} 
qualquer atividade em sentido técnico: a organização, entendida como a predisposição dos fatores estruturais indispensáveis ao exercício daquela série coordenada de atos.

Há em qualquer atividade, por mais rudimentar que seja, prévia deliberação do agente no sentido de estruturar (organizar) o mínimo de condições que lhe permitam, por meio da série de atos, atingir o fim a que se propõe.

Assim, pensa-se que só se estará diante de verdadeira atividade em sentido técnico, se se puder vislumbrar a composição de uma estrutura minimamente organizada para buscar, por meio de série de atos, o fim almejado ${ }^{128}$.

\subsubsection{Omissão}

A conduta por omissão, sem dúvida, é a que mais exige do intérprete espírito científico, indispensável para que se distinga o ôntico do deôntico.

No mundo fenomênico, toda e qualquer alteração só pode ocorrer por ação, mesmo porque, do nada (omissão), nada advém (ex nihilo nihil fit), sendo essa constatação multimilenar origem da noção pré-socrática de causa eficiente.

Não obstante, no mundo da cultura, a noção de causação é normativa: o sistema de direito positivo estabelece o que causa o que ${ }^{129}$. Neste ambiente cultural, a

empresária e mercados, São Paulo, Atlas, 2004; Cláudio Luiz Bueno de Godoy, Responsabilidade civil pelo risco da atividade: uma cláusula geral no Código Civil de 2002, 2ª ed., Coleção Professor Agostinho Alvim, coordenação Renan Lotufo, São Paulo, Saraiva, 2010; Antonio Junqueira de Azevedo, Responsabilidade civil ambiental. Reestruturação societária do grupo integrado pela sociedade causadora do dano. Obrigação solidária do causador indireto do prejuízo e do controlador de sociedade anônima. Limites objetivos dos contratos de garantia e de transação. Competência internacional e conflito de leis no espaço. Prescrição na responsabilidade ambiental e nas ações de regresso (parecer), in Novos Estudos e Pareceres de Direito Privado, São Paulo, Saraiva, $1^{\text {a }}$ ed., $2^{\mathrm{a}}$ tiragem, 2010, p. 395-426.

${ }^{128}$ É o que demonstra Cláudio Luiz Bueno de Godoy ao tratar do transporte gratuito (carona): "Poder-se-ia cogitar, no caso figurado [carona], de uma obrigação indenizatória independente de culpa pelo especial risco que há em transportar alguém na condução de um veículo automotor. Aliás a hipótese poderia mesmo ser alargada para qualquer caso em que um particular, ocasionalmente dirigindo seu veículo, causasse dano a alguém. Ocorre que, nesses casos, faltaria pressuposto para aplicação do parágrafo único do art. 927, justamente pela não caracterização de uma atividade, cuidando-se, antes, da prática de um ato, ainda que recoberto de risco e mesmo que habitual ou costumeiro o oferecimento de carona ou utilização do carro para locomoção. Não se configuraria atividade pela ausência de uma sequência coordenada de atos, ou organizados para alcance de uma dada finalidade, de um escopo, de um objetivo único juridicamente considerado". GODOY, Cláudio Luiz Bueno de, op. cit., p. 73. 
omissão adquire relevância, podendo, pois, ser elevada à condição de causa eficiente de certos acontecimentos.

Mas, para que se compreenda a omissão como causa, é necessário que se lhe estabeleça a noção e a estrutura.

Como conduta, a omissão é produto de uma decisão: a de não agir. Pressuposto dessa decisão, como de resto de qualquer outra, é a liberdade, isto é, a ausência de condicionamentos materiais ou psicológicos. Sem a liberdade de opção entre agir ou não agir, não há omissão.

A omissão é, então, modalidade de conduta necessariamente valorada, pois só haverá omissão se o agente podendo agir ou não agir, opta conscientemente por quedarse inerte.

Este decidir não querer agir, embora necessário para caracterizar a omissão, não é suficiente para configurar a omissão juridicamente relevante. Esta exige a conjugação da efetiva potencialidade de agir com o dever jurídico de fazê-lo.

Diante de um crime de roubo em andamento, por exemplo, uma terceira pessoa se omite se, tendo possibilidade de agir, deixa de fazê-lo, porém essa sua omissão é irrelevante porque ausente o dever de agir. Ao contrário, haverá omissão juridicamente relevante se essa terceira pessoa não for um cidadão comum, mas um policial.

Assim, desde que se tome consciência da distinção entre causalidade natural e causalidade normativa - ou princípio da imputação, caso se prefira a terminologia de Hans Kelsen -, não é mais possível deixar de considerar a omissão como causa eficiente de resultados.

${ }^{129}$ É a consagrada distinção levada a efeito por Hans Kelsen entre causalidade e imputação. Causalidade é princípio regente do domínio da natureza, enquanto a imputação é princípio das ciências que não se ocupam de descrever "a conduta humana determinada por leis causais, no domínio da realidade natural, mas como ela, determinada por normas positivas, isto é, por normas postas através de atos humanos, se deve processar".

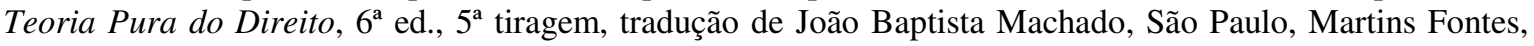
2003, p. 96. 


\subsubsection{Valoração da conduta: noção de ato ilícito e conduta culposa}

A análise da conduta requer ainda o estudo dos conceitos de ilicitude e culpa, pois é, fundamentalmente, entorno destas qualidades negativas que se estruturam muitas das hipóteses de responsabilização civil.

\subsubsection{Que é ato ilícito?}

Embora seja fundamental a distinção entre o mundo da cultura e o mundo da natureza, não se pode olvidar que o Direito não é exclusivamente formado por normas descritoras de fatos, mas que essas normas são, também, preenchidas por valores ${ }^{130}$, cabendo ao intérprete no desempenho de sua função guiar-se por tais vetores axiológicos.

As noções de ato ilícito e conduta culposa ${ }^{131}$ são exemplos de valorações jurídicas levadas a efeito para determinar a quem deve ser imputada a responsabilidade pela causação de um resultado.

Valendo-se da classificação das normas jurídicas que as distinguem em normas atributivas de competência e normas de conduta ${ }^{132}$, fica claro que o ato ilícito e a conduta culposa têm por ambiente próprio o das normas de conduta.

Com efeito, diante dos modais deônticos próprios das normas de conduta, a saber, proibido, obrigatório e permitido, há ato ilícito sempre que se faça algo descrito como proibido, ou deixe-se de fazer algo descrito como obrigatório, hipótese em que é mais preciso falar-se em omissão ilícita ${ }^{133}$. Já a conduta culposa é sempre um ato ilícito

\footnotetext{
${ }^{130}$ Como demonstrou Miguel Reale em sua Teoria tridimensional do direito: preliminares históricas e sistemáticas, $3^{\mathrm{a}}$ ed. revista e atualizada, São Paulo, Saraiva, 1980.

${ }^{131}$ Em razão do argumento a fortiori, a noção de conduta culposa abrange, aqui, a de conduta dolosa.

132 Sobre a classificação das normas em de conduta e de competência, cf.: ROSS, Alf, Logica de las normas, traducción por Jose S.P. Hierro, Madrid, Editorial Tecnos, 1971.

133 Há, entre os civilistas brasileiros, tendência no sentido de identificar o ato ilícito com a causação de dano. Neste sentido lê-se em Clóvis Bevilaqua: "Acto illicito é, portanto, o que, praticado sem direito, causa damno a outrem". Theoria Geral do Direito Civil, $2^{\text {a }}$ ed., Rio de Janeiro, Livraria Francisco Alves, 1929, p. 347. E em Francisco Amaral: "Ato ilícito é o ato praticado com infração de um dever legal ou contratual, de que resulta dano para outrem”. Op. cit., p. 552. Este autor inclusive identifica seu conceito com os conceitos apresentados por Silvio Rodrigues, Orlando Gomes e Caio Mario da Silva Pereira. Porém, o ato ilícito danoso é apenas uma modalidade de ato ilícito, conceito pertencente não ao Direito Civil, mas à Teoria Geral
} 
decorrente da violação de norma que imponha dever de cuidado, afinal a culpa consiste na violação do dever de cuidado que cabe ao homem médio observar.

Fica, pois, evidenciado que a relação entre ato ilícito e conduta culposa é relação entre gênero e espécie ${ }^{134}$.

Como ensinam os doutrinadores que versam a responsabilidade civil ${ }^{135}$, atualmente, esta disciplina vem sofrendo alteração relativamente à abordagem que confere aos personagens envolvidos: houve um deslocamento do foco de interesse da responsabilidade civil, que do autor do dano passou a sua vítima.

Ora, enquanto o foco da responsabilidade civil esteve voltado ao autor do dano, o sistema jurídico procedeu à valoração de sua conduta, somente imputando-lhe o dever de indenizar se sua conduta, além de danosa, fosse considerada um mal em si mesma, violadora de norma de conduta e, por isso, ilícita. Se a norma violada fosse a impositiva de dever de cuidado, falar-se-ia de conduta culposa; se, conscientemente dirigida à causação do mal, conduta dolosa.

No momento em que se altera o eixo de interesse da responsabilidade civil, voltando-se todas as atenções à vítima, o que passa a ser valorado mais enfaticamente é o

do Direito. Conforme já afirmado, o ato ilícito consiste na conduta contrária ao Direito, pouco importa se desta conduta decorre ou não dano a outrem. Nesse sentido, Pontes de Miranda, Tratado de Direito Privado Parte Geral - Tomo II - Bens. Fatos Jurídicos, $3^{\mathrm{a}}$ ed., Rio de Janeiro, Borsoi, 1970, p. 201; e Menezes Cordeiro, Tratado de direito civil português, v. II - Direito das Obrigações, Tomo III - Gestão de negócios, enriquecimento sem causa, responsabilidade civil, Coimbra, Almedina, 2010, p. 444. Poder-se-á argumentar que o Código Civil brasileiro traz conceitos próprios de ato ilícito, quais sejam os dos artigos 186 e 187. O artigo 187, como que completando a redação do artigo 186, inicia seu texto com a frase "também comete ato ilícito...", permitindo concluir que não só o ato danoso, como também o abusivo é ilícito. Porém, da conjugação destes artigos não se pode inferir que o Código Civil brasileiro tenha optado por uma noção restritiva de ato ilícito, ao contrário, apenas descreveu o suporte fático de duas modalidades de ato ilícito, sem com isso pretender excluir quaisquer outras.

${ }^{134}$ Assim, não há ato culposo que não seja ilícito, mas, é perfeitamente possível ato ilícito sem culpa. Neste sentido, Pontes de Miranda ensina que: "À contrariedade a direito não é essencial juntar-se culpa; há o contrário a direito sem culpa, como se o devedor não paga porque não contou com a interrupção do pagamento por seus devedores ou se ocorre algum caso de responsabilidade pelo fortuito ou força maior". Tratado de Direito Privado - Parte Geral - Tomo II - Bens. Fatos Jurídicos, $3^{\text {a }}$ ed., Rio de Janeiro, Borsoi, 1970, p. 197.

${ }_{135}$ Por todos, Geneviève Viney, As tendências atuais do direito da responsabilidade civil, tradução de Paulo Cezar de Mello, in Direito Civil Contemporâneo: novos problemas à luz da legalidade constitucional: anais do Congresso Internacional de Direito Civil-Constitucional da cidade do Rio de Janeiro, organizador TEPEDINO, Gustavo, São Paulo, Atlas, 2008, p. 42-56. 
dano, e não a sua causa, é dizer, a conduta, daí falar-se em "ocaso da culpa"136, ou em esvaziamento axiológico da responsabilidade civil.

Contudo, no ordenamento jurídico brasileiro, mesmo após a entrada em vigor do Código Civil de 2002, há a convivência de ambos os sistemas de responsabilidade civil, isto é, tanto o fundado na valoração da conduta do autor do dano, como o voltado mais diretamente aos interesses da vítima do dano.

Assim sendo, o sistema brasileiro de responsabilidade civil, estruturado a partir da noção de dano injusto, é formado por normas descritoras de condutas ilícitas e normas que abstraem qualquer valoração da conduta. No primeiro caso, se está diante da responsabilidade civil subjetiva; no segundo, da objetiva. Quando se trata de responsabilidade civil subjetiva, só surgirá o dever de indenizar se a conduta do agente foi dolosa ou culposa, sendo certo que, como já sinalizado, estes elementos são irrelevantes para a caracterização da responsabilização objetiva ${ }^{137}$.

\subsubsection{Dolo e culpa}

Tratando esse item da valoração da conduta, mister se faz analisar, ainda que sucintamente, alguns aspectos atinentes às noções de dolo e culpa.

O dolo e a culpa são categorias da teoria geral do direito, sendo inexato atribuir-lhes conceitos distintos de acordo com o campo da dogmática jurídica em que estão sendo versados. O que pode variar, e de fato varia, é a importância destas categorias para cada um dos ramos do Direito.

Para o Direito Penal, por exemplo, o dolo é categoria fundamental, enquanto que para o Direito Civil é categoria que, graças ao argumento a fortiori, é quase que dispensável. Explica-se. Em sede de responsabilidade civil, a hipótese normativa que exige

136 SCHREIBER, Anderson, Novos paradigmas da responsabilidade civil: da erosão dos filtros da reparação à diluição dos danos, $2^{\mathrm{a}}$ ed., São Paulo, Atlas, 2009.

137 Importante salientar que a regra no sistema jurídico brasileiro é a responsabilidade civil subjetiva. Apenas haverá responsabilidade civil objetiva, nos termos do que preceitua o artigo 927, parágrafo único, do Código Civil, "nos casos especificados em lei, ou quando a atividade normalmente desenvolvida pelo autor do dano implicar, por sua natureza, risco para os direitos de outrem". 
maior grau de valoração da conduta do agente para que se configure o dever de indenizar é a que impõe sua realização culposa, grosso modo entendida como não intencional. Assim, se o agente responde por mera conduta não intencional, com mais razão responderá quando quis o resultado ou aceitou o risco de produzi-lo. Sendo assim, deixar-se-á de analisar o dolo e passar-se-á ao estudo da culpa ${ }^{138}$.

Os autores que se dedicam ao estudo do Direito Civil reconhecem que o conceito de culpa é de difícil fixação ${ }^{139}$, mas parece que a dificuldade é resultado de certa imprecisão de parte da doutrina consistente em não distinguir culpa de culpabilidade.

No direito brasileiro, dentre os clássicos, Alvino Lima, por exemplo, apoiando-se, sobretudo, nos estudos dos irmãos Mazeaud, de Chironi e Luigi Abello, exige para a caracterização da culpa que o agente tenha imputabilidade moral, isto é, capacidade de agir de acordo com o padrão esperado ${ }^{140}$.

No mesmo sentido, já entre os autores contemporâneos, Francisco Amaral, valendo-se da definição de culpa de Savatier, afirma que "a culpa consiste na violação de um dever que o agente podia conhecer e observar. Seus pressupostos são um dever violado (elemento objetivo) e a culpabilidade ou imputabilidade do agente (elemento subjetivo)"141. Marcelo Junqueira Calixto conceitua culpa como sendo: "erro de conduta, imputável ao agente, consistente em não adotar o cuidado que teria sido adotado pelo ser humano prudente nas circunstâncias do caso concreto ${ }^{142,}$.

Vê-se que os autores incluem na noção de culpa a capacidade de entendimento do agente, o que, como muito bem explicam os estudiosos do Direito Penal $^{143}$, é requisito de configuração da culpabilidade, e não da culpa.

${ }^{138}$ É comum o emprego da palavra culpa em sentido amplo, para assim designar o dolo (vontade consciente dirigida a realizar ou aceitar realizar conduta que viola norma jurídica) e a culpa em sentido estrito (negligência ou imprudência).

${ }^{139}$ Cf. DIAS, José de Aguiar, Da responsabilidade civil, Tomo I, $5^{\mathrm{a}}$ ed., Rio de Janeiro, Forense, 1973, p. 127; CALIXTO, Marcelo Junqueira, A culpa na responsabilidade civil: estrutura e função, Rio de Janeiro, Renovar, 2008, p. 7.

${ }^{140}$ LIMA, Alvino, Culpa e risco, São Paulo, Revista dos Tribunais, 1960, p. 47-76.

${ }^{141}$ AMARAL, Francisco, op. cit., p. 555.

${ }^{142}$ CALIXTO, Marcelo Junqueira, op. cit., p. 31. O autor, na nota de rodapé 31, reconhece a semelhança de seu conceito com o de Alvino Lima.

${ }^{143}$ Luiz Regis Prado ensina que a culpabilidade pode ser conceituada como: "censurabilidade pessoal da ação ou omissão típica e ilícita". O autor afirma que, segundo Welzel, o seu fundamento está "na capacidade 
A culpabilidade é o juízo de reprovação moral sobre dada conduta ilícita. Com recurso à noção de culpabilidade, o intérprete decidirá se as consequências do ato ilícito praticado podem ser atribuídas ao agente e, para tanto, verificará se, no momento em que agiu ilicitamente, tinha consciência, ainda que potencial, da ilicitude do fato, bem como de agir de acordo com esta consciência e, também, se era legítimo exigir que se comportasse de maneira diversa da que, efetivamente, comportou-se.

Como se nota, o juízo de culpabilidade é sempre posterior à ocorrência de um ato ilícito, como é o caso da conduta culposa, razão pela qual são institutos absolutamente inconfundíveis.

Sobre o tema, e com apoio direto em ampla doutrina penal, Maurício Bunazar escreveu que:

“A culpa é a violação de um dever de conduta, dever esse préestabelecido por um tipo abstrato de agir de conduta diligente dentro das condições do caso concreto. Não se trata do estabelecimento de um padrão válido para todas as hipóteses, e sim de um critério a ser adotado pelo julgador diante do caso posto. Assim, para saber se houve culpa, o juiz perguntará a si mesmo se, diante das circunstâncias em que se achava o agente quando o dano se deu, o agente-tipo teria agido de maneira diversa, evitando o dano. Caso a resposta seja afirmativa, haverá culpa, do contrário, não. A culpa não é um juízo de reprovação moral sobre uma conduta, que é matéria atinente à

do autor de agir de outro modo". Apoiando-se ainda na teoria finalista de Welzel, diz que a culpabilidade é formada por três elementos: (a) imputabilidade, que consiste na "plena capacidade (estado ou condição) de culpabilidade, entendida como capacidade de entender e de querer, e, por conseguinte, de responsabilidade criminal (o imputável responde pelos seus atos). (...) Essa capacidade possui, logo, dois aspectos: cognoscitivo ou intelectivo (capacidade de compreender a ilicitude do fato); e volitivo ou de determinação da vontade (atuar conforme essa compreensão)"; (b) potencial consciência da ilicitude, definida como "o elemento intelectual da reprovabilidade, sendo a consciência ou o conhecimento atual ou possível da ilicitude da conduta. Trata-se, então, da possibilidade de o agente poder conhecer o caráter ilícito de sua ação consciência potencial (não real) da ilicitude"; e (c) exigibilidade de conduta diversa: "Com a confirmação da imputabilidade e da potencial consciência do injusto, encontra-se substancialmente firmada a culpabilidade. Contudo, isso não é suficiente ainda para que a ordem jurídica estabeleça a censura de culpabilidade. Há casos em que se acha fortemente atenuada a possibilidade de agir conforme a norma. Daí, a inexigibilidade de comportamento de acordo com o direito". PRADO, Luiz Regis, Curso de direito penal brasileiro - Parte Geral - arts. $1^{\circ}$ a 120, v. I, $5^{\text {a }}$ ed. revista, São Paulo, Revista dos Tribunais, 2005, p. 438 e seguintes. 
culpabilidade, e sim é um fato jurídico consistente na violação de um dever de cuidado. Não é porque o deficiente mental ou a criança são incapazes de conhecer o dever de cuidado que eles não podem violá-lo"144.

Adota-se aqui, portanto, um conceito abstrato de culpa, já que se prescinde da análise, no caso concreto, da imputabilidade moral do agente.

Feita esta distinção entre culpa e culpabilidade, cabe ainda fazer menção às formas pelas quais a culpa apresenta-se e, posteriormente, à questão dos graus de culpa.

O Código Civil de 2002, em seu artigo $186^{145}$, da mesma forma que dispunha o Código Civil de 1916, artigo $159^{146}$, estabelece que a culpa é a negligência ou a imprudência.

A negligência relaciona-se com a omissão do agente que, podendo agir da forma como faria o homem médio, evitando o resultado danoso, não o faz por displicência, desídia ou desatenção.

A imprudência, por sua vez, é uma conduta positiva. Consiste "na precipitação, no procedimento inconsiderado, sem cautela, em contradição com as normas do procedimento sensato. É a afoiteza no agir, o desprezo das cautelas que devemos tomar em nossos atos" $" 147$.

Fala-se também em imperícia para referir-se à falta de conhecimento técnico para o exercício de profissão ou arte. Diz-se que a imperícia é a conduta imprudente ou negligente do agente habilitado para o ato, daí falar-se em culpa profissional.

144 Responsabilidade civil do incapaz: objetivação da culpa ou responsabilidade civil objetiva?, in Ensaios sobre responsabilidade civil na pós-modernidade, v. 2, coordenadores HIRONAKA, Giselda Maria Fernandes Novaes; SIMÃO, José Fernando, Porto Alegre, Magister, 2009, p. 300.

145 “Art. 186. Aquele que, por ação ou omissão voluntária, negligência ou imprudência, violar direito e causar dano a outrem, ainda que exclusivamente moral, comete ato ilícito".

146 "Art.159. Aquele que, por ação ou omissão voluntária, negligência, ou imprudência, violar direito, ou causar prejuízo a outrem, fica obrigado a reparar o dano. A verificação da culpa e a avaliação da responsabilidade regulam-se pelo disposto neste Código, arts. 1.518 a 1.532 e 1.537 a 1.553 ”.

${ }^{147}$ DIAS, José de Aguiar, Da responsabilidade civil - Tomo I, 5ª ed., Rio de Janeiro, Forense, 1973, p. 141. 
Esses são conceitos que se misturam, sendo perfeitamente possível utilizar tão somente o termo negligência para referir-se a qualquer deles ${ }^{148}$.

Com relação à graduação da culpa, essa é uma construção que remonta ao direito romano. Inicialmente, distinguiam-se dois graus de culpa: a culpa lata ou magna negligentia e a culpa levis. Mais tarde, os autores medievais passaram a trabalhar com a tripartição: culpa lata, culpa levis e culpa levissima"149.

Nas lições de José Fernando Simão:

“culpa grave, também denominada grosseira ou lata, é a cometida de tal modo que até o mais descuidado ou medíocre dos homens a teria evitado (...). A culpa leve ou ligeira é a que seria evitada com a atenção ordinária, com a adoção de diligências próprias de um bonus pater familias. Por fim, a culpa levíssima é a que só poderia ser evitável com atenção extraordinária (...)" ${ }^{\natural 150}$.

Até a entrada em vigor do Código Civil Brasileiro de 2002 era predominante entre os doutrinadores a irrelevância prática desta gradação da culpa, a final o quantum de indenização seria fixado com base na extensão do dano, e não no grau de culpa $^{151}$.

No entanto, o parágrafo único do artigo 944 do Código Civil de 2002 afastou-se dessa concepção tradicional, ao permitir que o juiz reduza equitativamente a indenização, se houver excessiva desproporção entre o grau de culpa e o dano.

\footnotetext{
${ }^{148}$ Silvio Rodrigues esclarece: "Em rigor, na idéia de negligência se inclui a de imprudência, bem como a de imperícia, pois aquele que age com imprudência, negligencia em tomar as medidas de precaução aconselhadas para a situação em foco; como, também, a pessoa que se propõe a realizar uma tarefa que requer conhecimentos especializados ou alguma habilitação e a executa sem ter aqueles ou esta, obviamente negligenciou em obedecer às regras de sua profissão e arte; todos agiram culposamente". RODRIGUES, Silvio, Direito Civil - responsabilidade civil, vol. 4, $20^{a}$ ed., São Paulo, Saraiva, 2003, p. 17.

${ }^{149}$ CORDEIRO, António Menezes, Tratado de direito civil português, v. II - Direito das Obrigações, Tomo III - Gestão de negócios, enriquecimento sem causa, responsabilidade civil, Coimbra, Almedina, 2010 , p. 472.

${ }^{150}$ SIMÃO, José Fernando, Responsabilidade civil do incapaz, São Paulo, Atlas, 2008. p. 193-194.

${ }^{151}$ Por todos, Anderson Schreiber, op. cit., p. 43-44.
} 
Acerca dessa disposição normativa, há na doutrina dois posicionamentos diametralmente opostos. Um primeiro entendimento reputa má a alteração legislativa, pois capaz de deixar a vítima sem integral reparação ${ }^{152}$; já um segundo posicionamento vê como justa a previsão normativa de redução equitativa do valor da indenização, por levar em consideração a dignidade humana do causador do dano ${ }^{153}$.

Vê-se, pois, que, embora a objetivação da responsabilidade civil seja tendência inegável, a culpa ainda ocupa lugar de destaque na estrutura da responsabilidade civil brasileira.

\subsubsection{Normas de pré-exclusão da ilicitude da conduta}

A responsabilidade civil subjetiva exige, para a deflagração da estrutura de responsabilização, que a causação do dano injusto tenha sido levada a efeito por ato ilícito. Assim sendo, para que surja o dever de indenizar, não basta a causação do dano injusto, é necessária, ainda, uma prévia violação do ordenamento jurídico: a prática do ato ilícito.

É neste contexto que surge a questão das causas de exclusão da ilicitude.

O sistema jurídico contém normas que pré-excluem a ilicitude da conduta $^{154}$, tornando lícitas condutas que, por serem dirigidas à causação de um mal, seriam em princípio ilícitas. Essas normas descrevem em seus antecedentes situações extraordinárias que, uma vez concretizadas no mundo fenomênico, têm como consequentes a autorização para que o agente dirija sua conduta à prática de um mal que, no entanto, será tido como justo para o Direito.

Estas normas vêm positivadas nos artigos 188, 929 e 930 do Código Civil, formando preceito único que pode ser expresso sob a seguinte fórmula: se, no exercício de

\footnotetext{
${ }^{152}$ Neste sentido, Álvaro Villaça Azevedo, Teoria Geral das Obrigações e Responsabilidade Civil, $11^{\mathrm{a}}$ ed., São Paulo, Atlas, 2008, p. 278-279.

${ }^{153}$ Neste sentido, José Fernando Simão, Responsabilidade civil do incapaz, São Paulo, Atlas, 2008, p. 200-201; e Paulo de Tarso Vieira Sanseverino, Princípio da reparação integral - indenização no Código Civil, São Paulo, Saraiva, 2010, p. 80 e seguintes.

${ }^{154}$ PONTES DE MIRANDA, Francisco Cavalcanti, Tratado de Direito Privado - Parte Geral - Tomo II - Bens. Fatos Jurídicos, $3^{\mathrm{a}}$ ed., Rio de Janeiro, Borsoi, 1970, p. 271 e seguintes.
} 
conduta encoberta por alguma causa de exclusão da ilicitude, o agente causar dano ao agressor, o dano será justo e não surgirá o dever de indenizar. No entanto, se causar dano a direito de terceiro, este dano será injusto e, embora praticado por conduta lícita, deverá ser indenizado.

As normas que pré-excluem a ilicitude da conduta podem afastar a deflagração da estrutura de responsabilização subjetiva justamente porque, diante de situações extremas, o direito permite que o agente dirija conscientemente sua conduta à prática de um mal, porém, em razão do permissivo legal incidente, aquilo que seria qualificado como dolo, passa a ser qualificado como ato lícito, podendo, consequentemente, obstar a responsabilização ${ }^{155}$.

Com relação, ainda, às causas de exclusão da ilicitude, duas questões devem ser aclaradas.

A primeira delas refere-se ao fato de que o Código Civil não contemplou expressamente entre as causas de exclusão da ilicitude a hipótese de estrito cumprimento do dever legal, como o fez o Código Penal em seu artigo 23, inciso III. No entanto, é pacífico entre os doutrinadores que o estrito cumprimento do dever legal também é hipótese que afasta o dever de indenizar, afinal, se o agente atua no estrito cumprimento de dever legal, não comete ato ilícito, e, sim, cumpre integralmente a norma que descreve o modo de exercer seu dever, ademais.

O segundo aclaramento visa a afastar o equívoco consistente em afirmar que as causas de pré-exclusão da ilicitude são causas de ruptura do nexo causal ${ }^{156}$. As causas de exclusão do nexo causal são supervenientes à conduta e excluem o dever de indenizar porque a substituem na causação do dano. Já com relação às causas de pré-exclusão da ilicitude, há claramente nexo de causalidade entre a conduta dirigida à causação do mal (dano) e o mal causado; porém o Direito, neste caso, autorizou a causação do dano. A diferença ressalta: nas causas de exclusão do nexo causal, o Direito decide que o agente

\footnotetext{
${ }^{155}$ Quando ato ilícito causa dano, o sistema jurídico qualifica esse dano como injusto. No entanto, quando se trata de causação de dano por conduta lícita, é fundamental estabelecer qual será o fator de qualificação do dano como injusto. Ora, essa qualificação só pode decorrer de uma opção normativa sendo, portanto, apriori.

${ }^{156}$ Neste sentido, Carlos Roberto Gonçalves, Direito civil brasileiro - responsabilidade civil, v. $4,5^{\text {a }}$ ed., São Paulo, Saraiva, 2010, p. 353.
} 
não causou o dano; nas causas de pré-exclusão da ilicitude, o Direito decide que o agente que causou o dano poderia causá-lo, e, portanto, não está obrigado a indenizá-lo.

\subsection{Dano}

A manutenção de um equilíbrio social mínimo é inegavelmente uma das funções do Direito como sistema de ordenação do convívio humano. Daí decorre a necessidade de o sistema jurídico contar com mecanismos de reestabilização social das mais variadas espécies ${ }^{157}$, entre as quais, encontra-se a qualificação jurídica de dado evento como dano injusto e, concomitantemente, as formas de sua anatematização.

Esta qualificação jurídica - de alguns eventos como danos injustos - segue lógica em certa medida evidente quando se atenta para duas constantes suas. A primeira dessas constantes é a que exige para caracterização do dano a afetação negativa da esfera jurídica da vítima, ou seja, que aquele evento seja, para ela, fonte de experiência traumática. A segunda constante diz respeito à natureza social do direito e consiste na possibilidade de poder imputar-se a algum sujeito de direito a responsabilização pelo evento traumático experimentado por outrem.

É, principalmente, com esta segunda constante que se relaciona o princípio geral do direito que impõe a todos o dever de a ninguém lesar.

\subsubsection{Neminem laedere}

O dever de não lesar outrem (neminem laedere ou alterum non laedere) é encontrado em famosa passagem de Ulpiano ${ }^{158}$, no Digesto, sendo assinalado pelo jurisconsulto romano como um dos três preceitos fundamentais do direito, ao lado dos

157 Por exemplo, a repressão aos crimes e à concorrência desleal e, também, a predisposição dos mecanismos de controle de constitucionalidade etc.

${ }^{158}$ Ulp. 1 reg., D. 1, 1, 10, 1: "Iustitia est constans et perptua voluntas ius suum cuique tribuendi. Iuris praecepta sunt haec: honeste vivere, alterum non laedere, suum cuique tribuere”. Em tradução livre: A justiça é a constante e perpétua vontade de dar a cada um o seu direito. Os preceitos do direito são: viver honestamente, a ninguém ofender, dar a cada um o que é seu. 
mandamentos de viver honestamente (honeste vivere) e de dar a cada um o que é seu (suum cuique tribuere).

Tais preceitos têm, contudo, sua origem em concepções da filosofia grega, absorvidas pelos romanos ao tempo da República, quando conquistaram a Grécia ${ }^{159}$.

O preceito suum cuique tribuere consubstancia a ideia de justo e injusto contida nos ensinamentos de Pitágoras, Sócrates, Platão e, sobretudo, nos conceitos aristotélicos de justiça comutativa e distributiva. O preceito neminem laedere é extraído do epicurismo, que considera o direito o resultado do pacto celebrado entre os homens de não ofenderem para não serem ofendidos. O preceito honeste vivere traduz a moral estóica, que elege a honestidade como o bem mais precioso ${ }^{160}$.

Pode-se dizer que a finalidade da justiça encerra-se no preceito suum cuique tribuere, consistindo os outros dois seus corolários: um (honeste vivere), o elemento moral; o outro (neminem laedere), o elemento negativo ${ }^{161}$.

Assim é que a proibição de a ninguém ofender "pressupõe a determinação concreta do que é 'meu' e do que é 'teu",162 e isso nada mais é do que a delimitação da esfera jurídica dos sujeitos de direito, algo que, em muitas situações concretas, não é simples de ser feito. Só por meio dessa delimitação torna-se possível identificar a lesão a um direito e, consequentemente, acionar os mecanismos destinados à responsabilização de um sujeito de direito.

O neminem laedere ou a manutenção da incolumidade da esfera jurídica alheia, como preferem alguns doutrinadores ${ }^{163}$, consubstancia princípio geral do direito ${ }^{164}$,

${ }^{159}$ MADEIRA, Hélcio Maciel França, adaptação para fins acadêmicos de excertos extraídos da obra Ensaios de Philosophia do Direito de José Mendes.

${ }^{160}$ Idem.

${ }^{161}$ Idem.

162 PONTES DE MIRANDA, Francisco Cavalcanti, Tratado de Direito Privado - Parte Especial - Tomo LIII - Direito das Obrigações: Fatos ilícitos absolutos. Atos-fatos ilícitos absolutos. Atos ilícitos absolutos. Responsabilidade. Danos causados por animais. Coisas inanimadas e danos. Estado e servidores. Profissionais, $3^{\mathrm{a}}$ ed., reimpressão, Rio de Janeiro, Borsoi, 1972, p. 14.

${ }^{163}$ MELLO, Marcos Bernardes de, Teoria do fato Jurídico - Plano da existência, $14^{\mathrm{a}}$ ed. revista, São Paulo, Saraiva, 2007, p. 221-222. Em suas palavras: “Todo ordenamento jurídico, com maior ou menor intensidade, contém, como básico, o princípio da incolumidade das esferas jurídicas individuais (...). Em consequência desse princípio, concretizado na fórmula latina neminem laedere, a ninguém é dado interferir, 
que fundamenta normas positivas de responsabilização, além de nortear-lhes a interpretação, e, servindo ao equilíbrio social, mantendo-o ou restituindo-o, qualifica-se, também, como uma das normas estruturais do ordenamento jurídico, na medida em que desempenha papel fundamental na realização da vocação do Direito: a pacificação social.

\subsubsection{Conceito de dano}

Etimologicamente, a palavra dano vem do latim damnum, que deriva do verbo demere, o qual significa tolher, privar, decrescer, diminuir, e é contrário a emere, que, por sua vez, significa adquirir, aparecer. Propriamente, a palavra dano significa "qualquer privação ou subtração sofrida por um sujeito em seu aspecto físico ou moral"165.

Em linguagem jurídica, Agostinho Alvim, inventariando os diversos conceitos atribuídos à palavra dano pela doutrina, observa que esse termo foi classicamente conceituado como toda e qualquer diminuição do patrimônio de alguém ${ }^{166}$. Segundo relatos trazidos pelo autor, isso se deu, muito provavelmente, devido à influência exercida pela definição de dano apresentada pelo jurisconsulto romano Paulo, em passagem do Digesto $^{167}$.

Esse conceito, no entanto, conforme relata ainda o autor, passou a ser contestado por grande parte da doutrina, pois ele não permitiria abranger os denominados danos não patrimoniais, já que a palavra patrimônio, em boa técnica, refere-se tão somente "ao conjunto das relações jurídicas de uma pessoa, apreciáveis em dinheiro"168.

legitimamente, na esfera jurídica alheia, sem o consentimento de seu titular ou autorização do ordenamento jurídico (...)". Idem.

${ }^{164}$ Este princípio permeia todo o ordenamento jurídico, podendo ser inferido do artigo $5^{\circ}$, inciso $\mathrm{V}$, da Constituição Federal, bem como de toda legislação infraconstitucional que estabeleça o dever de reparar danos injustos.

${ }^{165}$ ROMANI, Giovanni, Dizionario Generale de'Sinonimi Italiani, v. 1, Milano, Giovanni Silvestri, 1725 , p. 403, verbete "danno".

${ }_{166}$ ALVIM, Agostinho, Da inexecução das obrigações e suas consequências, $2^{\mathrm{a}}$ ed., São Paulo, Saraiva, 1955, p. 185-188.

${ }_{167}$ Idem. Essa constatação é, segundo Agostinho Alvim, de Giovanni Formica. A passagem a que este autor se refere é a seguinte: Paul. 47 ad ed., D. 39, 2, 3: "Damnum est damnatio ab ademptione et quasi deminutione patrimonii dicta sunt".

${ }^{168}$ Idem. 
Alguns doutrinadores insurgiram-se contra esta crítica, requerendo fosse dado um conceito mais abrangente ao termo patrimônio, de forma a abarcar também as relações não patrimoniais ${ }^{169}$. Não houve muito sucesso.

Ganharam força, então, os conceitos de dano que procuram fazer menção tanto à natureza patrimonial quanto à natureza não patrimonial que ele pode assumir. Tornou-se comum o recurso à figura do bem jurídico ${ }^{170}$. Afirma-se, assim, que dano é "a diminuição ou subtração de um bem jurídico" ${ }^{171}$ ou "a lesão de qualquer bem jurídico"172.

No entanto, dado à vagueza da expressão bem jurídico, que tanto pode significar o objeto de direito subjetivo ${ }^{173}$, como o próprio direito subjetivo, prefere-se conceituar dano recorrendo-se à categoria da esfera jurídica, assentando-se, assim, que dano é toda afetação negativa da esfera jurídica alheia ${ }^{174}$.

\footnotetext{
${ }^{169}$ Idem.

${ }^{170}$ Ibid., p. 186-188.

${ }^{171}$ FORMICA, Giovanni apud ALVIM, Agostinho, Da inexecução das obrigações e suas consequências, $2^{a}$ ed., São Paulo, Saraiva, 1955, p. 187.

${ }^{172}$ ALVIM, Agostinho, Da inexecução das obrigações e suas consequências, $2^{\mathrm{a}}$ ed., São Paulo, Saraiva, 1955, p. 187. Esse autor ainda traz um conceito de dano em sentido amplo: "Nós entendemos que o têrmo dano, em sentido amplo, vem a ser a lesão de qualquer bem jurídico, e aí se inclui o dano moral". Idem. Hans Albrecht Fischer entende que: "É dano todo o prejuízo que o sujeito de direitos sofra através de violação dos seus bens jurídicos, com excepção única daquele que a si mesmo tenha inferido o próprio lesado: êsse é juridicamente irrelevante". FISCHER, Hans Albrecht, A reparação dos danos no direito civil, tradução de António de Arruda Ferrer Correia, São Paulo, Livraria Acadêmica - Saraiva \& C. ${ }^{\text {a }}$ - Editores, 1938, p. 7.

${ }^{173}$ Emprega-a nesse sentido, por exemplo, Menezes Cordeiro. CORDEIRO, António Menezes, Tratado de direito civil português, v. II - Direito das Obrigações, Tomo III - Gestão de negócios, enriquecimento sem causa, responsabilidade civil, Coimbra, Almedina, 2010, p. 511-512.

${ }^{174}$ Esse conceito de dano tem a ver com o que Antônio Junqueira de Azevedo denomina dano-prejuízo. Precisando os vocábulos "lesão", "dano" e "prejuízo", frequentemente utilizados na língua portuguesa para se referirem, ora ao ato que viola o bem jurídico, ora ao prejuízo que resulta desta lesão, o autor ensina que dano-evento é o primeiro momento, isto é, o ato que viola o bem juridicamente protegido, já o dano-prejuízo é o segundo momento, ou seja, o prejuízo resultante da violação. AZEVEDO, Antonio Junqueira, $O$ direito como sistema complexo e de $2^{a}$ ordem; sua autonomia. Ato nulo e ato ilícito. Diferença de espírito entre responsabilidade civil e penal. Necessidade de prejuízo para haver direito de indenização na responsabilidade civil (parecer), in Estudos e pareceres de direito privado, São Paulo, Saraiva, 2004, p. 3334. Esta distinção é de grande importância. Em regra, tanto o dano-evento quanto o dano-prejuízo estarão presentes. Entretanto, é perfeitamente possível que haja dano-evento sem que haja dano-prejuízo. Pode-se pensar no seguinte exemplo: um pedreiro quer demolir o muro de sua própria casa. Programa para executar o serviço em determinado dia. No dia anterior ao que iria executá-lo, um caminhoneiro embriagado perde a direção do veículo que conduzia e colide no muro, derrubando-o. Não há aqui dano-prejuízo. Há tão somente dano-evento. A conduta do caminhoneiro violou uma posição jurídica subjetiva alheia (ingerência ilegítima na esfera jurídica alheia), mas esse ato não gerou prejuízo, isto é, não gerou efetiva repercussão (afetação) negativa a essa posição jurídica. Logo, não há dever de indenizar. O que se indeniza é o dano-prejuízo.
} 
A esfera jurídica designa a totalidade das posições jurídicas subjetivas de que é titular um sujeito de direito ${ }^{175}$. Seu conteúdo é variável, podendo ser mais ou menos $\operatorname{amplo}^{176}$.

$\mathrm{Na}$ esfera jurídica, identifica-se uma estrutura bipartida composta pelos chamados hemisfério patrimonial e hemisfério não patrimonial. No hemisfério patrimonial, encontra-se a totalidade de posições jurídicas subjetivas ativas e passivas dotadas de valor econômico e, consequentemente, suscetíveis de expressão pecuniária. São posições jurídicas, tendencialmente, disponíveis. O hemisfério não patrimonial, por sua vez, é composto de posições jurídicas não suscetíveis de avaliação pecuniária, sendo, portanto, tendencialmente, indisponíveis ${ }^{177}$.

Em cada um desses hemisférios, ou setores, existe um núcleo onde se localizam as posições jurídicas indisponíveis - ilustrativamente, o núcleo do setor não patrimonial é maior do que o do setor patrimonial -. O ordenamento jurídico coloca nesses núcleos as posições jurídicas que considera as mais importantes, não permitindo ao titular da esfera jurídica delas dispor livremente ${ }^{178}$.

Dessas considerações, obtêm-se, conclusivamente, os conceitos de dano patrimonial e de dano não patrimonial ou moral. Diz-se que um dano é patrimonial quando é negativamente afetada posição jurídica localizada no setor patrimonial da esfera jurídica de um sujeito de direito. A expressão dano não patrimonial, por sua vez, tem a ver com

\footnotetext{
175 Esse conceito de esfera jurídica foi exposto pelo Professor Alcides Tomasetti Júnior em aulas ministradas no curso de direito da Faculdade de Direito da Universidade de São Paulo, durante o $1^{\circ}$ semestre de 2004. A expressão sujeitos de direito é preferível a de pessoas. Como é sabido, ao menos no ordenamento jurídico brasileiro, há entes que, embora desprovidos de personalidade jurídica, são titulares de algumas posições jurídicas ativas e passivas. Assim, por exemplo, a herança jacente e vacante e também a massa falida.

${ }^{176}$ Segundo ensina José Oliveira Ascensão: "Não se imagina uma esfera jurídica vazia: a esfera jurídica não é um mero continente. As pessoas singulares têm, logo que vêm à existência, direitos de personalidade". E, em nota a esta afirmação, o autor acrescenta: "E mesmo as pessoas coletivas desfrutam logo de direitos assim que adquirem personalidade jurídica. Não têm apenas capacidade, têm direitos concretos. Mas é um fato que a situação aqui é mais complexa, por uma pessoa coletiva poder nunca ter nenhuma atividade, ficando reduzida sempre aos direitos inerentes à sua personalidade jurídica”. ASCENSÃO, José de Oliveira, Direito Civil - Teoria Geral: Introdução. As pessoas. Os bens, v. I, $3^{a}$ ed., São Paulo, Saraiva, 2010, p. 126.

${ }^{177}$ Essas considerações sobre a esfera jurídica foram também expostas pelo Professor Alcides Tomasetti Júnior em aulas ministradas no curso de direito da Faculdade de Direito da Universidade de São Paulo, durante o $1^{\circ}$ semestre de 2004.

${ }^{178}$ Idem.
} 
lesões a posições jurídicas localizadas no setor não patrimonial da esfera jurídica de um sujeito de direito.

Sucede, todavia, que essa noção de dano, até aqui defendida, não é satisfatória para abarcar as hipóteses em que o sistema de responsabilização civil é chamado a atuar. Efetivamente, o que se indeniza não é o dano pura e simplesmente; mas o dano qualificado: o dano injusto.

\subsubsection{Sentido da expressão dano injusto}

Em obra clássica, Adriano De Cupis, após afirmar que há um conhecimento comum de dano oriundo da simples observação de que o homem ou as forças naturais podem alterar ou aniquilar situações favoráveis, ensina que o dano passa a ser objeto de conhecimento do jurista apenas quando é juridicamente qualificado ${ }^{179}$. Assim, leciona que a estrutura do dano é constituída de dois elementos: "o elemento material ou substancial, consistente no fato físico, representativo de seu núcleo interior, e o elemento formal, que é

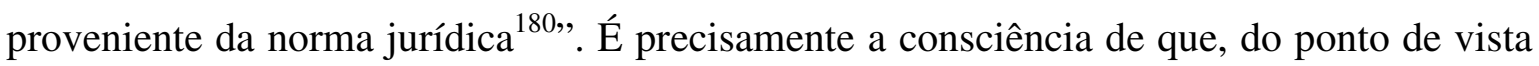
jurídico, não existe dano sem norma que assim o qualifique que enseja sua abordagem dogmática a partir da investigação acerca de sua justiça ou injustiça.

Esta qualificação do dano em justo ou injusto exige dois esclarecimentos.

O primeiro e mais importante é que a ideia de justiça, aqui, não é aquela ordinária, significativa de algo bom e valoroso, mas, meramente a posição do ordenamento jurídico relativamente a dado evento. Assim, o evento será considerado dano injusto se o ordenamento jurídico o tomar por intolerável e determinar sua eliminação ou compensação $^{181}$.

${ }^{179}$ DE CUPIS, Adriano, Il Danno - Teoria generale della respnssabilità civile, Milano, Dott. A. Giuffrè Editore, 1946, p. 5.

${ }^{180}$ Ibid., p. 6.

181 O conceito de dano injusto que aqui se adota é extraído do artigo Taxonomia da sanção civil: para uma caracterização do objeto da responsabilidade civil, de Maurício Bunazar, in Revista Juris da Faculdade de Direito, Fundação Armando Alvares Penteado, v. 5, janeiro a junho/2011, São Paulo, FAAP, 2010, p. 41. 
O segundo esclarecimento diz respeito ao artigo 2.043 do Código Civil italiano de 1942, que dispõe: "Qualquer fato doloso ou culposo que ocasiona a outrem um dano injusto obriga aquele que cometeu o fato a ressarcir o dano". O sentido da expressão dano injusto de que se vale o Codice é mais restrito do que aquele que se utiliza nesta dissertação, isto porque, ao que parece, o diploma legislativo italiano refere-se à injustiça como sinônimo de antijuridicidade ${ }^{182}$ - tanto que, na sequência, aborda as tradicionais causas de exclusão da ilicitude (artigos 2.044 e 2.045) -, enquanto que, aqui, enfatiza-se, valer-se-á da expressão dano injusto como significativa do evento causador de desequilíbrio social insuportável, sanável pelo mecanismo de balanceamento sistemático chamado responsabilidade civil, que, como se verá, mais do que o exigir, o pressupõe. Consequentemente, a expressão dano justo será empregada como sinônimo de dano que deve ser suportado pela vítima, independentemente das razões para tanto ${ }^{183}$.

\subsubsection{Espécies de dano}

A doutrina, baseada em critérios distintos, apresenta muitas espécies de dano injusto. Serão mencionadas as classificações que se crê serem as mais relevantes para delimitar o conceito de dano que aqui se defende.

\footnotetext{
${ }^{182}$ Neste sentido e pugnando por uma ampliação do significado da expressão dano injusto, Giuseppe Tucci, Il danno ingiusto, Napoli, Editore Jovene Napoli, 1970.

${ }^{183}$ Maurício Bunazar, valendo-se de possíveis combinações entre valoração positiva/negativa da conduta e resultado tolerável/intolerável, expõe quatro situações jurídicas com repercussão para o Direito Civil: "I. Ato ilícito e consequiência insuportável: conduta culposa (ato ilícito) causadora de dano injusto (conseqüência insuportável); abuso de direito (ato insuportável) e dano injusto alheio (conseqüência insuportável); II. Ato lícito e consequiência suportável: (i) sem prejuízo para ninguém: transporte de pessoas (ato lícito) com extinção do contrato pelo cumprimento (consequiência suportável), (ii) com dano-prejuízo justo - para alguém: reação em legítima defesa (ato lícito) causadora de dano estético ao agressor (consequiência suportável); III. Ato lícito e conseqüência insuportável: ato em exercício de estado de necessidade (ato lícito) com dano-prejuízo a patrimônio do não agressor (consequiência insuportável). Atividade criadora de risco, porém estimulada pelo Estado inclusive com incentivos fiscais (ato lícito) com dano-prejuízo ambiental (consequiência insuportável); IV. Ato ilícito sem consequiência: conduta culposa sem causação de qualquer dano-prejuízo". O autor, então, conclui que: "só haverá responsabilidade civil em sentido estrito nas hipóteses I e III, pois só estas possuem o constante necessário (ainda que nem sempre suficiente) para a deflagração da estrutura de responsabilização civil senso estrito: o dano-injusto". Taxonomia da sanção civil: para uma caracterização do objeto da responsabilidade civil, de Maurício Bunazar, in Revista Juris da Faculdade de Direito, Fundação Armando Alvares Penteado, v. 5, janeiro a junho/2011, São Paulo, FAAP, 2010, p. 42.
} 


\subsubsection{Danos patrimoniais e danos não patrimoniais}

A classificação mais empregada pela doutrina e também pela jurisprudência é a que distingue os danos patrimoniais ou danos materiais dos danos não patrimoniais, também denominados danos extrapatrimoniais ou danos morais.

Como já dito, quando se tratou do conceito de dano, dano patrimonial é toda afetação negativa de posição jurídica subjetiva, ativa ou passiva, de natureza patrimonial, isto é, dotada de valor econômico e, consequentemente, suscetível de avaliação pecuniária. O conceito de dano não patrimonial, por sua vez, é obtido por exclusão: a afetação negativa de posição jurídica subjetiva não patrimonial $^{184}$.

São danos patrimoniais: a desaparição do direito subjetivo real decorrente da destruição por outrem do objeto sob o qual incida, a incapacitação total ou parcial para o trabalhado que resultou das ofensas físicas praticadas pelo agressor. Representam danos não patrimoniais: o sofrimento do pai pela perda do filho assassinado, o constrangimento experimentado por aquele que teve sua intimidade indevidamente exposta ao público, o vexame por que passou aquele que foi injuriado, o trauma psicológico daquele que teve membro amputado em virtude de lesões cometidas por outrem.

É claro que da mesma situação jurídica injusta podem advir, concomitantemente, danos patrimoniais e danos não patrimoniais. Pode-se pensar em um acidente de trânsito, em que o táxi envolvido ficou destruído e o taxista sofreu lesões corporais. Estas configuram dano não patrimonial. Já a destruição do automóvel constitui dano patrimonial.

A doutrina costuma salientar que a distinção entre dano patrimonial e não patrimonial não tem a ver com a natureza do objeto lesado pelo evento danoso ${ }^{185}$. A

\footnotetext{
${ }^{184}$ Neste sentido, Antonio Junqueira de Azevedo, Por uma nova categoria de dano na responsabilidade civil: o dano social, in Novos Estudos e Pareceres de Direito Privado, $1^{\mathrm{a}}$ ed., $2^{\mathrm{a}}$ tiragem, São Paulo, Saraiva, 2009, p. 378.

${ }^{185}$ Cf. CORDEIRO, António Menezes, Tratado de direito civil português, v. II - Direito das Obrigações, Tomo III - Gestão de negócios, enriquecimento sem causa, responsabilidade civil, Coimbra, Almedina, 2010, p. 513; COSTA, Mário Júlio de Almeida, op. cit., p. 543-544; DIAS, José de Aguiar, Da responsabilidade civil - Tomo II, $5^{\text {a }}$ ed., Rio de Janeiro, Forense, 1973, p. 357. JORGE, Fernando de Sandy Lopes Pessoa, op. cit., p. 373; NORONHA, Fernando, Direito das obrigações - fundamentos do direito das obrigações - introdução à responsabilidade civil, v. 1, 2ª ed. rev. e atual., São Paulo, Saraiva, 2007, p. 557.
} 
classificação cujo critério é a natureza do objeto lesado é a que contrapõe os danos pessoais ou danos à pessoa aos danos não pessoais ou danos a coisas. Os primeiros são "produzidos em pessoas". Os segundos "se verificam sobre coisas". Trata-se, pois, de classificações independentes ${ }^{186}$.

Assim, é perfeitamente possível que conduta alheia incidente sobre coisa seja fonte de dano não patrimonial. Por exemplo, a morte de animal, em virtude de atropelamento, que leva seu dono a um estado depressivo ${ }^{187}$. Também é possível que conduta alheia incidente sobre a pessoa da vítima cause a esta dano patrimonial. Os autores costumam citar os seguintes exemplos: a difamação da qual resulta o dano moral e, ainda, a diminuição da clientela; as ofensas corporais que levam à incapacidade para o trabalho; a perda dos alimentos em decorrência do homicídio daquele que está obrigado a prestá-los $^{188}$.

\subsection{Danos emergentes e lucros cessantes}

O dano patrimonial abrange o dano emergente (damnum emergens) e o lucro cessante (lucrum cessans). Diz-se que o primeiro provoca a diminuição do patrimônio do lesado e o segundo impede o seu aumento pela frustração de um lucro esperado $^{189}$.

$\mathrm{Na}$ legislação brasileira, os danos emergentes e os lucros cessantes, designados pela expressão perdas e danos, vêm definidos, respectivamente, como aquilo que efetivamente se perdeu e aquilo que razoavelmente se deixou de lucrar ${ }^{190}$.

\footnotetext{
${ }^{186}$ COSTA, Mário Júlio de Almeida, op. cit., p. 544.

${ }^{187}$ Fernando Noronha traz o seguinte exemplo: "um álbum de velhas fotografias familiares pode ou não ter valor econômico, mas certamente que o tem afetivo". NORONHA, Fernando, op. cit., p. 557.

${ }^{188}$ JORGE, Fernando de Sandy Lopes Pessoa, op. cit., p. 373; COSTA, Mário Júlio de Almeida, op. cit., p. 543-544.

189 ALVIM, Agostinho, op. cit., p. 189.

${ }^{190}$ Artigo 402 do Código Civil brasileiro de 2002: "Salvo as exceções expressamente previstas em lei, as perdas e danos devidas ao credor abrangem, além do que ele efetivamente perdeu, o que razoavelmente deixou de lucrar". Em idêntico teor, artigo 1.059, caput, do Código Civil de 1916: "Salvo as exceções previstas neste Código, de modo expresso, as perdas e danos devidos ao credor abrangem, além do que ele efetivamente perdeu, o que razoavelmente deixou de lucrar". Encontra-se na doutrina antiga o emprego da expressão danos e interesses (tradução para o português da expressão dommages et intérêts prevista no Código Civil francês) no lugar de perdas e danos. A preferência por aquela justifica-se porque perdas e danos
} 
Aquilo que efetivamente se perdeu pode consistir numa diminuição do ativo ou num aumento do passivo ${ }^{191}$. De fato, se o enriquecimento é o incremento de uma posição jurídica ativa ou a diminuição de uma posição jurídica passiva, o dano emergente é o incremento de uma posição jurídica passiva ou a diminuição de uma posição jurídica ativa. No exemplo já citado do acidente envolvendo o táxi, as despesas com reparo do automóvel e com tratamento médico configuram danos emergentes.

Já o lucro cessante é o não incremento de posição jurídica ativa ou a não diminuição de posição jurídica passiva que ocorreria se os eventos seguissem o seu desdobramento causal normal.

Emprega-se, pois, na determinação do lucro cessante, um juízo de razoabilidade, consoante prescreve a lei civil brasileira ${ }^{192}$.

De fato, não é tarefa simples aferir os lucros cessantes. Fischer já observava que, se por um lado não se exige a certeza absoluta de que o lucro teria se verificado, não fosse a interferência do evento danoso, por outro, trabalhar com a mera possibilidade também não é adequado ${ }^{193}$.

É bastante esclarecedor, nesse sentido, o $§ 252$ do BGB, o qual aduz: “como cessante considera-se o lucro que, de conformidade com o curso habitual das coisas, ou de conformidade com as circunstâncias especiais, particularmente com as disposições e prevenções adotadas, pode, com verossimilhança, ser esperado".

Com base nesse dispositivo, Fischer conclui que deve existir "uma certa probabilidade objectiva, que resulte do «curso normal das coisas» e das «circunstâncias especiais do caso concreto»"194.

são palavras sinônimas, que designam apenas o dano emergente. Todavia, consagrou-se no direito pátrio perdas e danos. Cf. ALVIM, Agostinho, op. cit., p. 191-193.

${ }^{191}$ ALVIM, Agostinho, op. cit., p. 191; VARELA, João de Matos Antunes, op. cit., p. 599.

192 Cf. o artigo 402 do Código Civil já citado.

${ }^{193}$ FISCHER, Hans Albrecht, op. cit., p. 51.

${ }^{194}$ Idem. 
Apoiando-se nos estudos de Fischer, a doutrina brasileira ${ }^{195}$ construiu, então, a interpretação do termo "razoavelmente" empregada pelo artigo 402 do Código Civil.

Entende-se, assim, por razoável aquilo que, provavelmente, ocorreria dentro do curso normal dos fatos, tendo em vista as especificidades do caso concreto ${ }^{196}$.

A indenização devida ao taxista pelos valores que deixou de ganhar durante os dias em que seu veículo permaneceu no conserto funda-se na probabilidade de que ele, durante esse período, continuaria trabalhando. $\mathrm{O}$ mesmo se dá em relação à indenização de alimentos devida aos dependentes do empregado vítima de homicídio. Contudo, valendo-se aqui de exemplo utilizado por Fernando Noronha ${ }^{197}$, já não é certo que, no futuro, esse empregado, que sempre desempenhou suas atividades com muito zelo e competência, passaria a ocupar cargo mais alto e, assim, auferir renda maior, que justificasse um aumento do valor da indenização devida aos seus dependentes.

Está-se, nesse último caso, diante do denominado dano eventual, incerto ou hipotético, definido como o prejuízo de verificação meramente possível, ou duvidosa e, portanto, não reparável ${ }^{198}$.

Não se pode ignorar, todavia, as situações de responsabilidade civil pela perda de uma chance, que é tema extremamente próximo do aqui tratado, embora com ele não se confunda.

Ainda que não haja consenso acerca da natureza jurídica da perda de uma chance, ela pode ser mais bem compreendida se for analisada sob duas óticas distintas: a do causador do dano e a da vítima.

\footnotetext{
195 ALVIM, Agostinho, op. cit., p. 203-210. DIAS, José de Aguiar, Da responsabilidade civil - Tomo II, $5^{\mathrm{a}}$ ed. revista e aumentada, Rio de Janeiro, Forense, 1973, p. 347-350.

${ }^{196}$ Isso implica dizer que deve o intérprete partir da presunção de que os fatos aconteceriam segundo seu curso normal e, assim, admitir que a vítima lucraria aquilo que o bom senso diz que ela lucraria. É do agente chamado a indenizar o ônus de provar o contrário. ALVIM, Agostinho, op. cit., p. 204.

${ }^{197}$ NORONHA, Fernando, op. cit., p. 583.

198 NORONHA, Fernando, op. cit., p. 581.
} 
Do ponto de vista do causador do dano, deve ser entendida como a conduta ilícita que afetou negativamente a esfera jurídica alheia por obstar ou interromper sucessão de eventos que tinham chance séria e real de culminar no surgimento ou incremento de posição jurídica ativa ou na diminuição de posição jurídica passiva, ou no não surgimento ou incremento de situação passiva para a vítima. Do ponto de vista da vítima, o dano consiste, justamente, na perda dessa chance ${ }^{199}$.

Com relação à espécie de dano causado, a doutrina diverge, havendo quem o entenda patrimonial, moral ou mesmo tertium genus $^{200}$.

Caso se entenda que o dano é pura e simplesmente a perda da chance, não há outra opção senão enquadrá-lo como dano moral ${ }^{201}$. No entanto, para fins de determinação do modus e quantum da indenização, parece mais coerente que o enquadramento da espécie de dano dê-se de acordo com a natureza da chance perdida ${ }^{202}$. Assim, a perda da chance pode ocasionar dano moral ou patrimonial, ou mesmo moral e patrimonial.

Com base nessas constatações, percebe-se que a distinção entre lucro cessante e perda de uma chance circunscreve-se ao fato de que no lucro cessante a análise recai sobre a probabilidade objetiva de obtenção de um lucro e, na perda de uma chance,

${ }^{199}$ O que é indenizado é justamente a chance de não alcançar determinado resultado, ou de auferir certo benefício, chance que foi perdida pela vítima em razão de ato culposo do lesante. Cf.: MARTINS-COSTA, Judith, Comentário ao novo Código Civil, vol. V, tomo II: do inadimplemento das obrigações, arts. 389 a 420, coordenador TEIXEIRA, Sálvio de Figueiredo, Rio de Janeiro, Forense, 2004, p. 360. NORONNHA, Fernando, op. cit., p. 676-679.

${ }^{200}$ Sobre os vários posicionamentos, cf.: Sergio Cavalieri Filho, Programa de responsabilidade civil, $8^{\mathrm{a}}$ ed. revista e ampliada, São Paulo, Atlas, 2008, p. 77-79.

${ }^{201}$ Sérgio Savi entende que o dano é patrimonial, pois a chance já era algo pertencente ao patrimônio da vítima. Responsabilidade civil por perda de uma chance, São Paulo, Atlas, 2006, p. 102. Parece que o autor vale-se da expressão patrimônio como sinônimo de esfera jurídica, imprecisão semântica que explica o equívoco de raciocínio.

${ }^{202}$ Embora se deva concordar com Judith Martins Costa e Fernando Noronha quando afirmam que o dano não é a vantagem perdida, mas a perda da chance de obter a vantagem, do ponto de vista operacional parece mais eficiente entender que à natureza da posição jurídica ativa afetada (não surgida ou não incrementada pelo perdimento da chance) caberá informar ao intérprete sobre o regime jurídico reparatório que será chamado a regular a hipótese em análise, por exemplo, se será deflagrada a estrutura de responsabilização para que se indenize dano injusto patrimonial ou extrapatrimonial; se a responsabilização seguirá a lógica da responsabilidade obrigacional ou extraobrigacional etc. 
sobre a certeza de impedimento ou interrupção da sucessão de eventos que tinham chance séria e real de culminar na obtenção de uma vantagem ou na evitação de um prejuízo ${ }^{203}$.

Por fim, cabe um último registro em relação à classificação dos danos patrimoniais aqui analisada. Não se pode pretender estabelecer uma relação necessária entre dano emergente e dano presente e entre lucro cessante e dano futuro.

São danos presentes todos aqueles que já tenham-se verificado quando da prolação da sentença que fixa o valor da indenização. Futuros, por sua vez, são aqueles que, neste momento, ainda não se concretizaram, mas que, segundo o desenrolar normal dos fatos e as peculiaridades do caso concreto, revelam-se certos ${ }^{204}$.

Assim, pode o dano emergente dizer respeito a um dano que irá verificar-se no futuro, como as terapias a que terá de submeter-se a vítima de lesão corporal grave que podem durar meses ou até mesmo anos. Também os medicamentos de que ela necessite podem ser de uso continuado. De outro lado, o lucro cessante pode configurar dano presente. É o que sucede com os valores que esta vítima de lesão corporal grave deixou de ganhar até a data da sentença em virtude da sua incapacitação para o trabalho ${ }^{205}$.

\subsection{Danos não patrimoniais}

Conforme já mencionado, o dano não patrimonial também é chamado de dano extrapatrimonial ou dano moral. No direito brasileiro, consagrou-se a terminologia dano moral por ser a utilizada pelo legislador constitucional e infraconstitucional, que, nesse aspecto, sofreu influência do direito francês ${ }^{206}$.

\footnotetext{
${ }^{203}$ Cf.: GUEDES, Gisela Sampaio da Cruz, Lucros cessantes - do bom-senso ao postulado normativo da razoabilidade, São Paulo, Editora Revista dos Tribunais, 2011.

${ }^{204}$ COSTA, Mário Júlio de Almeida, op. cit., p. 547; LEITÃO, Luís Manuel Teles de Menezes, op. cit., 332.

${ }^{205}$ Cf. JORGE, Fernando de Sandy Lopes Pessoa, op. cit., p. 378; SANSEVERINO, Paulo de Tarso Vieira, op. cit., p. 184-185.

${ }^{206}$ No francês: dommage moral.
} 
Diversamente, na Alemanha, na Itália e também em Portugal, a terminologia adotada pelo legislador é dano não patrimonial ${ }^{207}$. Essa preferência justifica-se porque, em boa técnica, "dano moral" designa "o dano que atenta contra o conceito que a coletividade tem da pessoa, isto é, que viola elementos valorativos (ou virtudes) da pessoa, como ser social" ${ }^{, 208}$, referindo-se apenas, portanto, às afetações negativas de uma das parcela de posições jurídicas subjetivas localizadas no hemisfério não patrimonial da esfera jurídica dos sujeitos de direito. Assim, considerada a esfera jurídica da pessoa natural, ficariam excluídas, por exemplo, as lesões à integridade física e psíquica.

Os danos não patrimoniais, segundo já afirmado, constituem afetações negativas de posições jurídicas localizadas no hemisfério não patrimonial dos sujeitos de direito. Não há um rol taxativo de danos não patrimoniais, pelo contrário, na sociedade contemporânea, com o progresso científico e tecnológico, surgem novos direitos subjetivos (por exemplo, direito à identidade genética ${ }^{209}$ ) e, consequentemente, novos danos podem ser ocasionados. É possível, contudo, condensá-los, como o faz a doutrina brasileira em alusão à classificação dos direitos da personalidade proposta por Rubens Limongi França $^{210}$, na tripartição: danos corporais ou físicos, danos psíquicos ou intelectuais e

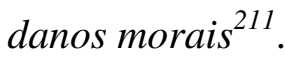

A grande discussão que existiu sobre os danos não patrimoniais foi a atinente a possibilidade de serem ressarcidos. E isso se deu porque, de fato, os danos não

\footnotetext{
207 Conferir, por exemplo, no BGB, \$\$253 e 847 (der nicht Vermögensschaden ist); no Código Civil italiano, artigo 2.059 (danno non patrimoniale); no Código Civil de Portugal, artigo $496^{\circ}$ (danos não patrimoniais).

${ }^{208}$ NORONHA, Fernando, op. cit., p. 559. Esse conceito de dano moral de Fernando Noronha baseia-se no conceito de direito moral proposto por Carlos Alberto Bittar, para quem direitos morais são aqueles "respeitantes a atributos valorativos (ou virtudes) da pessoa na sociedade (o patrimônio moral, compreendendo: a identidade; a honra; as manifestações do intelecto)". Os direitos da personalidade, $3^{\mathrm{a}}$ ed. revista e atualizada, Rio de Janeiro, Forense Universitária, 1999, p. 17.

209 ALMEIDA, Silmara Juny de Abreu Chinellato e, Reprodução humana assistida: aspectos civis e bioéticos, tese apresentada ao Departamento de Direito Civil da Faculdade de Direito da Universidade de São Paulo para concurso de livre-docência, 2000.

210 De acordo com Rubens Limongi França, os direitos da personalidade podem ser classificados em: direito à integridade física, direito à integridade intelectual e direito à integridade moral. $\mathrm{O}$ autor assevera: "Evidentemente, esses Direitos não são estanques, senão, pelo contrário, por vezes participam de mais de um grupo, como o Direito à Imagem, que nos parece tanto de natureza moral como física. Não obstante, assentada esta base, os Direitos da Personalidade podem ser especificados dentro de uma classificação correspondente à sua natureza dominante". Direitos da Personalidade: coordenadas fundamentais, in Revista dos Tribunais, São Paulo, v. 567, janeiro de 1983, p. 09-16; Manual de direito civil, v. 1, 4ª ed. revista, São Paulo, Revista dos Tribunais, 1980, p. 411-412.

${ }^{211}$ Ainda que nem todos os direitos não patrimoniais sejam direitos da personalidade, esta classificação pode ser utilizada. Cf.: NORONHA, Fernando, op. cit., 559.
} 
patrimoniais não permitem "uma verdadeira e própria reparação ou indemnização", porque não são suscetíveis de avaliação pecuniária ${ }^{212}$.

No ordenamento jurídico brasileiro, o debate perdeu força com a promulgação da Constituição Federal de 1988, que, dentre os direitos e garantias fundamentais, elenca expressamente a indenização por dano moral (artigo $5^{\circ}$, inciso V).

A doutrina que defende a reparação dos danos não patrimoniais - hoje majoritária, pelo menos no Brasil - justifica-a com base na ideia de que, embora não seja possível encontrar um preço que corresponda ao valor do bem violado, deve-se propiciar à vítima alguma compensação pelo dano sofrido, devendo o montante de indenização guardar "razoável relação de equivalência com a extensão dos prejuízos extrapatrimoniais sofridos pela vítima"213.

Tem-se aqui, é verdade, uma mitigação do princípio da reparação integral dos danos, que "busca colocar o lesado em situação equivalente à que se encontrava antes de ocorrer o ato ilícito", que, de resto, até mesmo em sede de danos patrimoniais, é "uma utopia, pois dificilmente se alcançará a inteira reparação de todos os prejuízos sofridos pela vítima, o que é feito de forma apenas aproximativa"214.

Hoje, o sistema jurídico brasileiro enfrenta nova controvérsia envolvendo os danos morais, porém desta vez não para negar sua existência, mas para determinar se sua função limita-se à reparação da vítima, ou se comporta também a punição do ofensor. Esse assunto, em razão de sua importância, será analisado mais detalhadamente no capítulo 4 .

${ }^{212}$ COSTA, Mário Júlio de Almeida, op. cit., p. 549.

${ }^{213}$ SANSEVERINO, Paulo de Tarso Vieira, op. cit., p. 272-273. Maurício Bunazar observa: “é o sistema jurídico que confere ao julgador as balizas (por exemplo, artigo 944, caput e parágrafo único do Código Civil) para determinar como o responsável anatematizará o dano-prejuízo injusto. Tais balizas podem ser mais precisas, como ocorre no dano patrimonial; ou mais tênues, no caso do dano moral. Porém, de forma alguma se pode confundir uma baliza tênue com ausência de baliza. O que há no caso do dano moral ou do dano ambiental extrapatrimonial, por exemplo, é uma maior discricionariedade do juiz na apreciação da existência e extensão do dano, o que, conseqüentemente, repercutirá na forma e/ou montante da indenização". Taxonomia da sanção civil: para uma caracterização do objeto da responsabilidade civil, in Revista Juris da Faculdade de Direito, Fundação Armando Alvares Penteado, v. 5, janeiro a junho/2011, São Paulo, FAAP, 2010, p. 41.

${ }^{214}$ SANSEVERINO, Paulo de Tarso Vieira, op. cit., p. 19 e 271-272. 


\subsubsection{Danos diretos, danos indiretos e danos reflexos}

Das situações em que, ao atingir-se uma determinada posição jurídica de um sujeito de direito, gera-se um dano e, como consequência deste dano, surge outro dano, extrai-se a classificação dos danos em diretos e indiretos. Fala-se que os danos diretos são os efeitos imediatos da situação jurídica injusta; ao passo que os danos indiretos são os que advêm dos danos diretos, sendo, portanto, consequências mediatas da situação jurídica injusta $^{215}$.

Assim, a difamação da honra do empresário e as lesões corporais sofridas por alguém são exemplos de danos diretos de natureza não patrimonial. A morte do animal de estimação que foi atropelado é exemplo de dano direto patrimonial. Por outro lado, a diminuição da clientela decorrente da difamação do empresário e a incapacidade para o trabalho resultante das lesões corporais sofridas constituem danos patrimoniais indiretos. Já o estado depressivo em que se encontra aquele que perdeu seu animal de estimação, em um atropelamento, configura dano moral indireto.

Muitos doutrinadores ${ }^{216}$ empregam a expressão dano indireto para designar também o denominado dano reflexo ou dano em ricochete, que é o dano reflexamente sofrido por terceiros, como consequência do dano que fora causado à vítima.

Não se vislumbram prejuízos quanto a este uso da expressão: à fórmula dano indireto pode ser dado um sentido amplo, de modo a contemplar os danos indiretos causados à própria vítima, e, também, aqueles reflexamente causados a outros sujeitos de direito. Entende-se, contudo, que a expressão dano reflexo ou em ricochete deve ficar reservada às hipóteses em que o dano causado à vítima repercute negativamente na esfera jurídica de terceiro - como uma espécie de dano indireto.

$\mathrm{O}$ aspecto mais relevante acerca dos danos reflexos ou em ricochete é a sua determinação no caso concreto, pois, como assente em doutrina ${ }^{217}$, são excepcionais.

\footnotetext{
${ }^{215}$ COSTA, Mário Júlio de Almeida, op. cit., p. 547; VARELA, João de Matos Antunes, op. cit., p. 601602.

${ }^{216}$ GONÇALVES, Carlos Roberto, Direito civil brasileiro - responsabilidade civil, v. 4, $5^{\mathrm{a}}$ ed., São Paulo, Saraiva, 2010, p. 358. MARTINS-COSTA, Judith, op. cit., p. 354-355.
} 
No direito brasileiro, o artigo 948, inciso II, do Código Civil traz hipótese em que dano patrimonial reflexamente causado a terceiro deve ser ressarcido. Este é o caso da indenização das prestações alimentícias devida aos dependentes do alimentante, vítima de homicídio.

Além desta hipótese, a doutrina e a jurisprudência pátrias têm admitido indenização ao terceiro por dano a ele reflexamente causado em outras situações que não encontram previsão legal expressa. Pode-se mencionar, como exemplo, os danos não patrimoniais experimentados pelo cônjuge ou companheiro, bem como pelos filhos, pelo pai, pela mãe daquele que foi vítima de homicídio ${ }^{218}$. Importa saber, então, o que permite qualificar estes danos como injustos.

A solução para esta questão deve ser a seguinte: há de haver entre a vítima do dano e o terceiro atingido um vínculo juridicamente tutelado. Com isso, evita-se dilação injustificada das situações jurídicas passíveis de ensejar a obrigação de indenizar ${ }^{219}$.

${ }^{217}$ VARELA, João de Matos Antunes, op. cit., p. 623. O autor afirma: “Tem direito à indemnização o titular do direito violado ou do interesse imediatamente lesado com a violação da disposição legal, não o terceiro que só reflexa ou indirectamente seja prejudicado". Ibid., p. 620-621.

${ }^{218}$ Na doutrina, cf.: NORONHA, Fernando, op. cit., p. 578-579; CAVALIERI FILHO, Sergio, op. cit., p. 86-88; SANSEVERINO, Paulo de Tarso Vieira, op. cit., p. 293-296. Na jurisprudência, cf.: Apelação $\mathrm{n}^{\circ}$ 0003536-72.2007.8.26.0390, do Tribunal de Justiça do Estado de São Paulo; Apelação 002245212.2008.8.19.00, do Tribunal de Justiça do Estado do Rio de Janeiro; Apelação n ${ }^{\circ} 70036215481$, do Tribunal de Justiça do Estado do Rio Grande do Sul; Apelação no 0090837-45.2007.805.0001-0, do Tribunal de Justiça do Estado da Bahia; REsp n 530.602/MA, do Superior Tribunal de Justiça.

${ }^{219}$ O Superior Tribunal de Justiça, no julgamento do Resp 1.076.160/AM, em 10 de abril de 2012, de relatoria do Ministro Luis Felipe Salomão, negou pedido de indenização por danos morais pleiteado pelo noivo em razão da morte de sua noiva, sob o fundamento de que ele não é parte da “'família' direta da vítima". Nos termos da ementa do acórdão: "DIREITO CIVIL. RECURSO ESPECIAL. RESPONSABILIDADE CIVIL. LEGITIMIDADE PARA O AJUIZAMENTO DE AÇÃO INDENIZATÓRIA DE DANOS MORAIS POR MORTE. NOIVO. ILEGITIMIDADE ATIVA. NECESSÁRIA LIMITAÇÃO SUBJETIVA DOS AUTORIZADOS A RECLAMAR COMPENSAÇÃO. 1. Em tema de legitimidade para propositura de ação indenizatória em razão de morte, percebe-se que o espírito do ordenamento jurídico rechaça a legitimação daqueles que não fazem parte da 'família' direta da vítima, sobretudo aqueles que não se inserem, nem hipoteticamente, na condição de herdeiro. Interpretação sistemática e teleológica dos arts. 12 e 948, inciso I, do Código Civil de 2002; art. 63 do Código de Processo Penal e art. 76 do Código Civil de 1916. 2. Assim, como regra - ficando expressamente ressalvadas eventuais particularidades de casos concretos -, a legitimação para a propositura de ação de indenização por dano moral em razão de morte deve mesmo alinhar-se, mutatis mutandis, à ordem de vocação hereditária, com as devidas adaptações. 3. Cumpre realçar que o direito à indenização, diante de peculiaridades do caso concreto, pode estar aberto aos mais diversificados arranjos familiares, devendo o juiz avaliar se as particularidades de cada família nuclear justificam o alargamento a outros sujeitos que nela se inserem, assim também, em cada hipótese a ser julgada, o prudente arbítrio do julgador avaliará o total da indenização para o núcleo familiar, sem excluir os diversos legitimados indicados. A mencionada válvula, que aponta para as múltiplas facetas que podem assumir essa realidade metamórfica chamada família, justifica precedentes desta Corte que conferiu legitimação ao sobrinho e à sogra da vítima fatal. 4. Encontra-se subjacente ao art. 944, caput e parágrafo único, do Código Civil de 2002, principiologia que, a par de reconhecer o direito à integral reparação, ameniza-o em havendo um dano irracional que escapa dos efeitos que se esperam do ato causador. 


\subsubsection{Danos obrigacionais e danos extraobrigacionais}

Distinguem-se ainda os danos obrigacionais dos danos
extraobrigacionais $^{220}$, consoante se esteja diante de dano oriundo ou não do descumprimento de uma obrigação previamente existente entre lesante e lesado.

Assim, entende-se que dano obrigacional é aquele decorrente do descumprimento pelo devedor de uma obrigação específica surgida de uma relação intersubjetiva de cunho obrigacional previamente existente entre ele e o lesado. Por sua vez, define-se dano extraobrigacional como aquele resultante da violação de direitos que não derivam de uma relação intersubjetiva obrigacional previamente existente entre lesante e lesado ${ }^{221}$.

É importante salientar que os danos obrigacionais abrangem não só aqueles que decorrem do descumprimento da obrigação principal, mas também dos deveres laterais ou anexos, decorrentes da boa-fé objetiva (artigo 422, Código Civil) ${ }^{222}$.

O sistema de responsabilidade civil atual, deveras, rechaça indenizações ilimitadas que alcançam valores que, a pretexto de reparar integralmente vítimas de ato ilícito, revelam nítida desproporção entre a conduta do agente e os resultados ordinariamente dela esperados. E, a toda evidência, esse exagero ou desproporção da indenização estariam presentes caso não houvesse - além de uma limitação quantitativa da condenação - uma limitação subjetiva dos beneficiários. 5. Nessa linha de raciocínio, conceder legitimidade ampla e irrestrita a todos aqueles que, de alguma forma, suportaram a dor da perda de alguém - como um sem-número de pessoas que se encontram fora do núcleo familiar da vítima - significa impor ao obrigado um dever também ilimitado de reparar um dano cuja extensão será sempre desproporcional ao ato causador. Assim, o dano por ricochete a pessoas não pertencentes ao núcleo familiar da vítima direta da morte, de regra, deve ser considerado como não inserido nos desdobramentos lógicos e causais do ato, seja na responsabilidade por culpa, seja na objetiva, porque extrapolam os efeitos razoavelmente imputáveis à conduta do agente. 6. Por outro lado, conferir a via da ação indenizatória a sujeitos não inseridos no núcleo familiar da vítima acarretaria também uma diluição de valores, em evidente prejuízo daqueles que efetivamente fazem jus a uma compensação dos danos morais, como cônjuge/companheiro, descendentes e ascendentes. 7. Por essas razões, o noivo não possui legitimidade ativa para pleitear indenização por dano moral pela morte da noiva, sobretudo quando os pais da vítima já intentaram ação reparatória na qual lograram êxito, como no caso. 8. Recurso especial conhecido e provido".

${ }^{220}$ Nos termos do que já foi exposto no capítulo 1 deste trabalho (n. r. 50), preferem-se as expressões obrigacional e extraobrigacional às expressões contratual e extracontratual, tendo em vista que se está diante ou não de inadimplemento de obrigações prévias, independentemente de sua fonte (contrato, testamento, promessa de recompensa, gestão de negócios etc.). Nesse sentido, cf. CORDEIRO, António Menezes, Tratado de direito civil português, v. II - Direito das Obrigações, Tomo III - Gestão de negócios, enriquecimento sem causa, responsabilidade civil, Coimbra, Almedina, 2010, p. 385 e seguintes.

${ }^{221}$ A existência de relação obrigacional entre as partes não impede que se configure hipótese de responsabilidade extracontratual. Imagine-se a hipótese de um contrato de empreitada. Tanto é possível que, em razão de atraso na entrega da obra, haja responsabilização civil contratual do empreiteiro, como é possível que haja responsabilização civil aquiliana do empreiteiro em virtude de um de seus empregados ter agredido fisicamente o dono da obra.

${ }^{222}$ Quanto à discussão sobre a natureza jurídica do dano por culpa in contrahendo e por culpa post pactum finitum, adota-se, in totum, as lições de Menezes Cordeiro, já mencionadas acima, que resolve a 


\subsubsection{Dano social}

No ano de 2004, Antonio Junqueira de Azevedo redigiu artigo ${ }^{223}$ em que lançou as bases científicas para que o sistema jurídico brasileiro pudesse contemplar nova categoria de dano: o dano social.

$\mathrm{O}$ autor reconheceu que o momento social atual caracteriza-se pela insegurança, o que tem levado muitos juristas a incluir na indenização função punitiva e/ou dissuasória, embora no mais das vezes sem fundamentação sistemática ${ }^{224}$.

Partindo da inegabilidade da norma ${ }^{225}$ contida no artigo 944 do Código Civil, Antonio Junqueira de Azevedo concluiu que a indenização não pode ir além do dano e que estendê-la dissimuladamente é mau direito ${ }^{226}$. Todavia, cumpriu seu papel de cientista e encontrou solução para a demanda social sem com isso violentar o direito positivo.

Ao invés de alargar o conteúdo da indenização, ignorando a regra positivada no artigo 944 do Código Civil, Antonio Junqueira de Azevedo adotou o caminho oposto e alargou com absoluta coerência - sem violar proibições legais, lógicas ou sistemáticas - o conceito de dano.

Segundo se pensa, o autor, mais do que alegar, demonstrou existir categoria de dano que não se confunde nem com o patrimonial nem com o moral, que se apresenta quando a conduta de alguém atinge toda a sociedade, gerando "rebaixamento imediato do

questão, distinguindo as diferentes funções que há entre responsabilidade obrigacional e aquiliana. Como mostra o autor, a primeira está a serviço do valor "contrato", enquanto a segunda, a serviço do valor "propriedade". A partir desta genial distinção, Menezes Cordeiro aduz que a responsabilidade dita précontratual e a chamada post pactum finitum, por inequivocamente estarem a serviço do valor contrato, devem ser tratadas sob o regime jurídico da responsabilidade obrigacional. Cf.: Tratado de direito civil português, $v$. II - Direito das Obrigações, Tomo III - Gestão de negócios, enriquecimento sem causa, responsabilidade civil, Coimbra, Almedina, 2010, p. 389-394; Tratado de direito civil português, v. I-Parte geral, Tomo IIntrodução. Doutrina geral. Negócio jurídico, Coimbra, Almedina, 2010, p. 406 e seguintes.

${ }^{223}$ AZEVEDO, Antonio Junqueira de, Por uma nova categoria de dano na responsabilidade civil: o dano social, in Novos estudos e pareces de direito privado, $1^{\mathrm{a}}$ ed., $2^{\mathrm{a}}$ tiragem, São Paulo, Saraiva, 2010, p. $377-$ 384.

${ }^{224}$ Idem.

${ }^{225}$ Numa alusão ao princípio da negação ou da inegabilidade dos pontos de partida, princípio básico da dogmática, referido por Tércio Sampaio Ferraz Jr.. Cf.: Introdução ao estudo do direito: técnica, decisão e dominação, $4^{\mathrm{a}}$ ed., São Paulo, Atlas, 2003.

${ }^{226}$ AZEVEDO, Antonio Junqueira de, op. cit., p. 377-378. 
nível de vida da população". A este rebaixamento do nível de vida da população, ele deu o nome de dano social ${ }^{227}$.

Ora, se com sua "conduta dolosa ou gravemente culposa" o agente causou dano não só à vítima, mas à sociedade como um todo, nada mais natural do que fixar indenização cujo montante abranja os danos experimentados pela vítima e aquele experimentado pela sociedade ${ }^{228}$.

Esse acréscimo ao quantum da indenização não tem natureza de punição (ainda que puna) nem de desestímulo (ainda que desestimule), mas estritamente de indenização, pois visa a recolocar a sociedade no nível em que estava antes da conduta que a rebaixou $^{229}$.

\subsection{Nexo de causalidade}

A conceituação ordinária do nexo de causalidade como ligação de um efeito a dada causa é capaz de esconder, sob o véu do mais simples truísmo, dificuldades teóricas e práticas de alta complexidade. Estas dificuldades ressaltam quando, em sede de Ciências

\footnotetext{
${ }^{227}$ AZEVEDO, Antonio Junqueira de, op. cit., p. 377-384.

${ }^{228}$ Idem.

229 Nas palavras de Antonio Junqueira de Azevedo: "O artigo 944 do Código Civil, ao limitar a indenização à extensão do dano, não impede que o juiz fixe, além das indenizações pelo dano patrimonial e pelo dano moral, também - esse é o ponto - uma indenização pelo dano social. A 'pena' - agora, entre aspas, porque no fundo é reposição à sociedade -, visa restaurar o nível social de tranquilidade diminuída pelo ato ilícito". Ibid., p. 381. Cumpre registrar que o autor entende que a indenização por dano social deve ser entregue à própria vítima, afirmando que esse seu entendimento é "somente uma opção de política legislativa”. O autor pondera: "É verdade que o acréscimo de indenização, resultante do dano social, poderia ir para um fundo, como já ocorre no caso dos danos ambientais. (...). Todavia, (...), pensamos que a indenização por dano social deva ser entregue à própria vítima, que foi parte do processo, eis que, para a obtenção da indenização, foi ela quem de fato trabalhou. (...). Os danos sociais, em tese, poderiam ir para um fundo como ressarcimento à sociedade, mas aí deveria ser por ação dos órgãos da sociedade, como o Ministério Público. As condições concretas em que vivemos não são, porém, favoráveis à criação de mais deveres para o Estado. (...) Aqui, no caso, estamos, pois, entendendo que o particular, na sua ação individual de responsabilidade civil, age também como defensor da sociedade. Exerce um munus público (...). O autor, vítima, que move a ação, age também como um 'promotor público privado' e, por isso, merece recompensa. Embora esse ponto não seja facilmente aceito no quadro da mentalidade jurídica brasileira, parece-nos que é preciso recompensar, e estimular, aquele que, embora por interesse próprio, age em benefício da sociedade. Trata-se de incentivo para um aperfeiçoamento geral”. Ibid., p. 383
} 
Sociais - como é o caso do Direito -, pretende-se resolver a questão da ligação de dado efeito a dada causa com base em observações do mundo físico ${ }^{230}$.

Ao menos para as Ciências Sociais, a causalidade deve ser entendida como procedimento seletivo realizado com vistas a certos interesses ${ }^{231}$, é o que ensina o sociólogo Niklas Luhmann:

"A causalidade, portanto, é sempre uma seleção que se deve atribuir a um observador com determinados interesses, com um tipo específico de estrutura de observação, e com uma capacidade bastante determinada de processar informação" 232 .

Com base nestas lições, verdadeiramente metodológicas, proceder-se-á à distinção fundamental entre causalidade e imputação e, na sequência, estudar-se-ão as chamadas teorias do nexo de causalidade, que nada mais são do que aquilo que Luhmann chamou de tipo específico de estrutura de observação. Também será abordado o tema das causas de exclusão do nexo causal.

\subsubsection{Relação de causalidade e relação de imputação. $O$ nexo físico e o nexo jurídico}

O espírito humano, em sua ínsita busca por respostas que o permita entender a realidade, cedo necessitou atribuir uma origem aos acontecimentos físicos mais relevantes para sua existência. Fê-lo, primeiramente, por meio da criação de lendas, mitos, deuses e, posteriormente, por meio do exercício da razão, baseada na observação e experimentação.

\footnotetext{
${ }^{230}$ É o equivoco de todos os que, como Fernando Noronha, imaginam possível a existência de responsabilidade civil sem nexo de causalidade. Cf.: Direito das Obrigações: fundamentos do direito das obrigações: introdução à responsabilidade civil, v. 1, $2^{\mathrm{a}}$ ed., São Paulo, Saraiva, 2007, p. 489.

231 "A articulação entre causas e efeitos realizada por um observador depende dos interesses com que ordena o objeto, ou na medida em que confere importância a determinados efeitos". Niklas Luhmann, Introdução à teoria dos sistemas, aulas publicadas por Javier Torres Nafarrate, tradução de Ana Cristina Arantes Nasser, Petrópolis, Editora Vozes, 2009, p 104.

232 Ibid., p. 105.
} 
Pode-se dizer que, de certo modo, a filosofia nasce desta ânsia por respostas, em que invariáveis são apenas as perguntas. Realmente, desde os filósofos pré-socráticos percebe-se a tentativa de explicar os fenômenos a partir da ideia de causa ${ }^{233}$, sendo certo que Aristóteles procedeu à sistematização conhecida como doutrina das quatro causas, entre as quais tem relevância imediata para este trabalho a causa eficiente ou impulsiva.

Para Aristóteles, a causa eficiente é aquela "de onde provém o começo primeiro da mudança ou do repouso, por exemplo, é causa aquele que deliberou, assim como o pai é causa da criança e, em geral, o produtor é causa do produzido e aquilo que efetua a mudança é causa daquilo que se muda ${ }^{234,}$, sendo dever do filósofo, isto é, do cientista descobrir e expor a causa geradora dos fenômenos investigados.

Após a sistematização aristotélica, os trabalhos puramente filosóficos que mais influenciaram o Direito em matéria de causalidade foram o de David Hume e Immanuel Kant. David Hume buscou demonstrar que todo conhecimento humano decorre da experiência e que a relação de causa e efeito não decorre de uma necessidade, mas é fruto da conclusão baseada em experiências anteriores ${ }^{235}$. Já Kant, influenciado profundamente pela obra de Hume, desenvolveu sua obra capital para, em apertadíssima síntese, demonstrar os limites da razão, a partir da constatação de que, embora todo conhecimento principie pela experiência, isto não significa que todo ele derive da

${ }^{233}$ Como ensina Gerd A. Bornheim, Aristóteles referia-se aos pré-socráticos como físicos, mas não no sentido moderno atribuído à palavra física, mas sim à physis, que compreende a totalidade de tudo o que é. "Pensando a physis, o filósofo pré-socrático pensa o ser, e a partir da physis pode então aceder a uma compreensão da totalidade do real: do cosmos, dos deuses e das coisas particulares, do homem e da verdade, do movimento e da mudança, do animado e do inanimado, do comportamento humano e da sabedoria, da política e da justiça". Os pré-socráticos, então, foram pioneiros na explicação do mundo circundante, o que fizeram, cada qual a sua maneira, também por meio do recurso à ideia de causa, seja ela "o fogo de Heraclito" ou "as forças do amor e do ódio de Empedocles". Os filósofos pré-socráticos. Clássicos Cultrix, São Paulo, Editora Cultrix, 1967, p. 14.

234 ARISTÓTELES, Física I-II, prefácio, tradução, introdução e comentários de Lucas Angioni, Campinas, Editora da Unicamp, 2009, Livro II, Capítulo 3, [194 23], p. 48.

${ }^{235}$ Para Hume, é apenas pela experiência "que podemos inferir a existência de um objeto da existência de outro. A natureza da experiência é a seguinte. Lembramo-nos de ter tido exemplos freqüentes da existência de objetos de uma certa espécie; e também nos lembramos que os indivíduos de uma outra espécie de objetos sempre acompanharam os primeiros, existindo em uma ordem regular de contigüidade e sucessão em relação a eles. Assim, lembramo-nos de ter visto aquela espécie de objetos que denominamos chama, e de ter sentido aquela espécie de sensação a que denominamos calor. Recordamo-nos, igualmente, de sua conjunção constante em todos os casos passados. Sem mais cerimônias, chamamos à primeira de causa e à segunda de efeito, e inferimos a existência de uma da existência da outra". HUME, David, Tratado da natureza humana: uma tentativa de introduzir o método experimental de raciocínio nos assuntos morais, $2^{\mathrm{a}} \mathrm{ed}$. rev. e ampliada, tradução Déborah Danowski, São Paulo, Editora Unesp, 2009, p. 116. 
experiência, ou seja, para demonstrar que a razão humana é dotada de certos conhecimentos a priori, fundamentais para toda e qualquer experiência ${ }^{236}$.

Embora Hume tenha-se dedicado mais detidamente sobre a questão da causalidade, Kant, pelo menos para o Direito, o supera em importância porque influenciou sobremaneira Hans Kelsen, talvez até hoje o filósofo do direito mais estudado do ocidente.

Assim como Kant afirma serem possíveis juízos acerca da realidade que sejam independentes de qualquer experiência, Hans Kelsen busca construir uma teoria universal do Direito, isto é, que não se limite a dado ordenamento específico ${ }^{237}$. Para concluir este projeto, Hans Kelsen necessariamente eleva suas afirmações à extrema abstração, o que, consequentemente, afastam-nas de qualquer realidade subjacente.

É, então, a partir deste plano abstrato que Hans Kelsen estrutura sua Teoria Pura, de características marcantes, entre as quais se destaca a cisão radical que realiza entre o ser e o dever ser. É justamente nesta cisão em que se acredita estar a chave para o início de uma coerente abordagem do nexo de causalidade.

Com efeito, os planos ontológico e deontológico seguem lógica diversa de compreensão, na medida em que, naquele, as relações de antecedente e consequente são descobertas, ao passo em que, neste, são construídas, ainda que a partir de, ou sobre, substrato ôntico. Por não resultar de uma necessidade, mas de uma decisão de poder ${ }^{238}$, a causalidade jurídica (imputação) não se submete aos mesmos limites a que se submete a causalidade natural $^{239}$.

\footnotetext{
${ }^{236}$ KANT, Immanuel, Crítica da razão pura, $7^{\mathrm{a}}$ ed., tradução de Manuela Pinto dos Santos e Alexandre Fradique Morujão, Lisboa, Fundação Calouste Gulbenkian, 2010.

${ }^{237}$ KELSEN, Hans, Teoria pura do direito, $6^{\mathbf{a}}$ ed., $5^{\mathrm{a}}$ tiragem, tradução João Baptista Machado, São Paulo, Martins Fontes, 1998, p. 1.

${ }^{238}$ Miguel Reale ensina que as fontes do direito "são sempre estruturas normativas que implicam a existência de alguém dotado de um poder de decidir sobre o seu conteúdo, o que equivale a dizer um poder de optar entre várias vias normativas possíveis, elegendo-se aquela que é declarada obrigatória, quer erga omnes, como ocorre nas hipóteses da fonte legal e da consuetudinária, quer inter partes, como se dá no caso da fonte jurisdicional ou da fonte negocial". REALE, Miguel, Fontes e modelos do direito: para um novo paradigma hermenêutico, São Paulo, Saraiva, 1994, p. 11.

${ }^{239}$ Sendo o inverso igualmente verdadeiro. O raio não deixará de matar o camponês em razão de isto ser "injusto".
} 
É por não se submeter a tais limites que, em matéria de nexo causal, o Direito pode-se comportar de, pelo menos, três maneiras distintas em relação à causalidade natural, isto é, utilizando-a, ignorando-a ou, de certa maneira, criando-a. Realmente, no mais das vezes, o Direito vale-se da causação física de uma consequência e a incorpora em seu sistema como causação jurídica, atribuindo ao causador mecânico a causação jurídica $^{240}$. Porém, casos há em que o Direito ignora certa sucessão causal natural, e deixa de atribuir a causação jurídica ao causador mecânico ${ }^{241}$. Finalmente, é perfeitamente possível que o Direito atribua a causação jurídica sem se valer de qualquer substrato causal natural imediato ${ }^{242}$.

A clareza dessa certa independência do Direito com relação ao natural é dogmaticamente fundamental para que se evitem más compreensões sistemáticas como as que resultam na afirmação da possibilidade de responsabilização civil sem nexo causal, quando, na verdade, simplesmente, se está diante de hipótese de responsabilização civil com nexo causal jurídico sem substrato em relação causal natural, afinal, se houve a atribuição a alguém do dever de indenizar, é porque houve imputação (causação jurídica).

É tarefa da doutrina, então, estabelecer os pressupostos teóricos para o reconhecimento da causação jurídica e, com isso, permitir ao intérprete realizar o direito da vítima à indenização. Esta tarefa doutrinária é realizada por meio do desenvolvimento e estudo das chamadas teorias do nexo causal.

\subsubsection{Teorias do nexo causal}

São muitas as teorias que surgiram para tratar da relação de causalidade entre a conduta e o resultado. Grande parte delas foi desenvolvida, sobretudo, pelo Direito Penal. Serão aqui mencionadas as que maior influência exercem no direito civil brasileiro.

\footnotetext{
${ }^{240}$ Por exemplo, o Direito atribui ao condutor do veículo o dever de reparar o dano que causou por ter colidido com outro veículo.

${ }^{241}$ Por exemplo, no caso de reconhecimento de culpa exclusiva da vítima.

${ }^{242}$ Por exemplo, no caso da responsabilização civil por dano causado por omissão.
} 
A primeira delas é a teoria da equivalência das condições ou teoria da equivalência dos antecedentes causais ou ainda da conditio sine qua non ${ }^{243}$, segundo a qual, causa é toda a condição sem a qual o dano não ocorreria da forma como ocorreu e no momento em que ocorreu. Para identificar quais fatos são causas do resultado, emprega-se a fórmula de Thyren ${ }^{244}$, denominada de processo hipotético de eliminação: elimina-se mentalmente certa condição da cadeia causal e se analisa se o resultado ainda assim ocorreria. Verificado o resultado, a condição suprimida não será considerada causa; não verificado, então, o será.

O clássico exemplo citado pela doutrina é aquele em que alguém é levemente lesionado por outrem e, ao ser conduzido ao hospital, falece numa colisão envolvendo a ambulância na qual se encontrava. Aplicando-se a teoria da conditio sine qua non, aquele que lesionou levemente a vítima deverá ser responsabilizado pela morte, porque, se não fosse por esta lesão, a vítima não viria a falecer no acidente de trânsito.

Deste exemplo, constata-se, claramente, o problema dessa teoria: a adoção de uma concepção naturalística de causa conduz a um regresso ao infinito.

De fato, se analisado o processo causal natural, são múltiplos os acontecimentos que concorrem para a verificação de um dano. Daí, porque, como já salientado, não se deve equiparar o nexo jurídico ao nexo físico ${ }^{245}$.

No direito brasileiro, o artigo 13, caput $^{246}$, segunda parte, do Código Penal consagra essa teoria, como regra. Nessa seara, a necessidade de constatação de dolo ou culpa do agente com relação ao resultado, bem como o princípio da tipicidade permitem

\footnotetext{
${ }^{243}$ Considera-se que o primeiro defensor dessa teoria foi Julius Glaser. Contudo, a fundamentação mais profunda dessa da teoria da equivalência é atribuída a Maximilian von Buri. ROXIN, Claus, Derecho penal Parte general - Tomo I - Fundamentos. La estructura de la teoria del delito, traducción de la $2^{\text {a }}$ edición alemana y notas por Diego-Manuel Luzón Peña, Miguel Díaz y García Conlledo e Javier de Vicente Remesal, Madrid, Editorial Civitas, 2001, p. 348-349.

${ }^{244}$ Cf.: HUNGRIA, Nelson, Comentários ao Código Penal, v. 1, tomo 2, arts. 11 a 27, $2^{\mathrm{a}}$ ed. revista e atualizada, Rio de Janeiro, Revista Forense, 1953, p. 62.

${ }^{245}$ Referindo-se à noção de causa dada pela teoria da equivalência das condições, Antunes Varella adverte: "Trata-se, porém, de um conceito manifestamente vasado nos moldes das ciências naturais, ao gosto da velha escola positivista, sem a menor audiência das finalidades específicas do direito, em geral, e do instituto da responsabilidade civil, em particular. Por isso mesmo não surpreende que ele conduza a resultados práticos que nenhum autor hesita em repudiar". VARELA, João de Matos Antunes, op. cit., p. 883.

246 "Art. 13. O resultado, de que depende a existência do crime, somente é imputável a quem lhe deu causa. Considera-se causa a ação ou omissão sem a qual o resultado não teria ocorrido”.
} 
conter, em parte, o efeito expansionista dessa orientação. Modernamente, entretanto, a doutrina da imputação objetiva ${ }^{247}$ tem propugnado pelo seu emprego aliado à necessidade de análise da criação pela conduta humana de "um risco juridicamente desvalorado" ${ }^{248}$. Destarte, constatado o resultado naturalístico, a etapa posterior consiste em verificar se aquela conduta cria ou incrementa um risco socialmente intolerável, verificado concretamente no resultado danoso.

Segue-se a teoria da causalidade adequada ${ }^{249}$, que parte da ideia da teoria anterior, contudo, dentre as condições que, uma vez suprimidas, levariam a não produção do resultado, somente serão causa aquelas que, segundo juízo empírico, são adequadas a produzi-lo.

Assim sendo, diante de uma pluralidade de causas que, eventualmente, concorrem para o resultado danoso, será causa efetiva aquela que, por um juízo abstrato de probabilidade, é, consoante o curso normal dos acontecimentos e os dados da experiência, hábil a produzi-lo. Este é o critério empregado para a aferição da adequação da causa.

\footnotetext{
247 Essa teoria encontra suas raízes em estudos de Hegel. Karl Larenz, valendo-se do pensamento hegeliano, desenvolveu-a no âmbito do Direito Civil. Richard Honig, por sua vez, adaptou o trabalho de Larenz ao Direito Penal. Nesta seara, a teoria da imputação objetiva ganhou força e, mais tarde, Claus Roxin, em sua obra Funcionalismo e imputação objetiva no direito penal, deu a ela uma sistematização. Também teve papel importante na elaboração de uma teoria geral da imputação objetiva Günther Jakobs. Cf. CRUZ, Gisela Sampaio da, O problema do nexo causal na responsabilidade civil, Rio de Janeiro, Renovar, 2005, p. 111-122. No Brasil, a teoria da imputação objetiva ainda está sendo apreciada pela doutrina.

${ }^{248}$ Cf.: PRADO, Luiz Regis, op. cit., p. 350 e seguintes. Este autor, analisando as origens dessa teoria nos estudos de Karl Larenz e Richard Honig, observa: "A imputação objetiva se apresenta como um complemento corretivo - e, em certas ocasiões, de superação - das diversas teorias causais". "Richard Honig (...) parte também do princípio de que o decisivo para o ordenamento jurídico não é a constatação de uma mera relação de causalidade, mas de uma relação jurídica especial entre a ação e o resultado. Não se trata de aferir a causalidade, mas de valorá-la". E prossegue: "O critério que permite imputar ao sujeito determinado fato e diferenciá-lo dos acontecimentos fortuitos é a finalidade objetiva. São, portanto, imputáveis, aqueles resultados que podem ser finalmente vislumbrados. Até o momento se está diante de um juízo puramente objetivo sobre a relação teleológica que vincula comportamento e resultado. Examina-se não o conhecimento e a vontade atuais do autor, ma sim suas capacidade potenciais. Por isso se trata de uma imputação objetiva, já que esta não indica qual a relação psíquica existente entre o sujeito e o resultado a ele imputado. Só terão significado jurídico as relações causais regidas pela vontade humana, ou seja, os processos causais cujo curso seja passível de previsão e de direção. Apenas os resultados previsíveis e dirigíveis pela vontade são imputáveis e somente a imputação objetiva permite a afirmação da tipicidade de uma ação. A imputação objetiva do resultado é, dessa forma, um pressuposto da tipicidade do comportamento". Ibid., p. 339-340. Procurando elaborar uma teoria geral da imputação objetiva, Claus Roxin desenvolveu alguns critérios que permitem atribuir um resultado a determinada conduta. Resumidamente, são eles: (i) diminuição do risco; (ii) criação ou não criação de um risco juridicamente relevante; (iii) aumento ou falta de aumento do risco permitido; (iv) âmbito de proteção da norma. Ibid., p. 340 e seguintes.

${ }^{249}$ Desenvolvida por Ludwig von Bar e Johannes von Kries. Cf.: HUNGRIA, Nelson, op. cit., p. 57.
} 
Valendo-se do exemplo acima descrito, deve-se concluir, portanto, que uma lesão corporal leve, em condições normais, não é causa adequada da morte, pelo que não deve o agressor ser por ela responsabilizado.

No âmbito do Direito Civil, nota-se, contudo, uma contradição, em alguns doutrinadores, quando da explicação da teoria da causalidade adequada.

Frequentemente, os autores ${ }^{250}$ expõem o conceito supramencionado e, em seguida, indagam sobre quais circunstâncias devem ser consideradas causas na "prognose confiada ao julgador" 251 : as que são conhecidas do homem médio ou aquelas que são conhecidas do agente. E aqui, então, são apontadas duas vertentes da teoria da causalidade adequada: a causalidade adequada objetiva e a causalidade adequada subjetiva. A doutrina resolve a querela afirmando que, no juízo abstrato de adequação, tanto as circunstâncias conhecidas à data do fato por uma pessoa normal como aquelas conhecidas do lesante nesta data devem ser levadas em consideração.

O problema é que, se for levado em consideração o conhecimento que o lesante tinha das circunstâncias na época da causação do dano, então, o juízo deixa de ser abstrato e passa a ser concreto.

Menezes Cordeiro traz, em sua obra, o exemplo que se reitera na doutrina, com algumas variações:

“A atinge $\mathrm{B}$, no peito, com um tiro; $\mathrm{B}$ morre: há causalidade, uma vez que o disparo no peito é 'causa adequada' de morte; A deixa cair os óculos e B morre de susto: não há causalidade, por falta de 'adequação'; porém, se A, herdeiro de B e conhecedor de uma sua insuficiência cardíaca, agravada por grande sensibilidade ao inesperado, deixa cair os óculos, para matar B que, de facto morre, já haverá responsabilidade. E adequação? Se a resposta for positiva, veremos que a fórmula da

\footnotetext{
${ }^{250}$ CRUZ, Gisela Sampaio da, op. cit., p. 64-69; SANSEVERINO, Paulo de Tarso Vieira, op. cit., p. 155156; VARELA, João de Matos Antunes, op. cit., 891-893.

${ }^{251}$ VARELA, João de Matos Antunes, op. cit., p. 892.
} 
'adequação' já não é bitola de coisa nenhuma: trata-se, apenas, de um espaço que iremos preenchendo com base no senso comum e em juízo de tipo ético, até que a Ciência do Direito seja capaz de explicar o fenómeno" ${ }^{\text {252 }}$.

Bem vistas as coisas, a crítica que, em geral, faz-se da causalidade adequada e que vem muito bem expressa no exemplo de Menezes Cordeiro não procede. É regra fundamental da convivência social que aquelas condutas dirigidas à causação de um mal e que logrem sua obtenção devem ser sancionadas (neminem laedere). A questão da causalidade adequada, justamente, põe-se quando a conduta não é voltada à prática de um mal, porém, acaba por produzi-lo. Nesta situação, é que se indaga se aquela conduta era abstratamente adequada para produzir o mal. Se a resposta for positiva, responsabiliza-se; do contrário, não.

Quando o agente, para valer-se do exemplo citado, sabe do mal cardíaco e, visando a matar a vítima, assusta-a, não se fala em teoria da causalidade adequada, pois ai a conduta, concreta, é imediatamente apta a produzir o mal. Logo, o agente deverá responder.

Isso significa que a causalidade adequada só deve ser aplicada quando houver dúvida razoável acerca da justiça de atribuir-se a alguém a responsabilidade pela ocorrência de um mal a outrem.

Passa-se à teoria do dano direto e imediato.

Esta teoria ganhou muito prestígio no direito brasileiro a partir do estudo que sobre ela fez Agostinho Alvim. O autor afirma ser essa a teoria adotada pelo então Código Civil de 1916 , no seu artigo $1.060^{253}$, cuja redação foi repetida no artigo $403^{254}$ do Código em vigor ${ }^{255}$.

\footnotetext{
${ }^{252}$ CORDEIRO, António Menezes, Tratado de direito civil português, v. II - Direito das Obrigações, Tomo III - Gestão de negócios, enriquecimento sem causa, responsabilidade civil, Coimbra, Almedina, 2010 , p. 535.

253 "Art. 1.060. Ainda que a inexecução resulte de dolo do devedor, as perdas e danos só incluem os prejuízos efetivos e os lucros cessantes por efeito dela direto e imediato".
} 
Para explicar a essência dessa doutrina, surgiram várias escolas, sendo a da necessariedade da causa a melhor delas, na opinião de Agostinho Alvim. De acordo com suas lições, uma condição, seja ela próxima ou remota, será considerada causa de determinado dano se estiver ligada diretamente a este. Diz-se, então, que "ela é causa necessária dêsse dano, porque a ela êle se filia necessàriamente; é causa exclusiva, porque opera por si, dispensadas outras causas"

Agostinho Alvim procura salientar o propósito desta teoria, que é o de identificar o aparecimento de outras causas que rompem o nexo causal e, assim, afastam a responsabilização do agente ${ }^{257}$, ou que produzem novos danos, em relação aos quais o agente não irá responder (é o caso, por exemplo, da "agravação do dano, por obra do credor" 258 ). E conclui: "os danos indiretos ou remotos não se excluem, só por isso; em regra, não são indenizáveis, porque deixam de ser efeito necessário, pelo aparecimento de concausas. Suposto não existam estas, aqueles danos são indenizáveis"259.

Ao lado da crítica de Fernando Noronha, que a entende por demais restritiva $^{260}$, pode-se, ainda, apontar a crítica que reputa impróprio aplicá-la à responsabilidade civil aquiliana, pois estaria funcionalizada a estabelecer a imputação dos

254 “Art. 403. Ainda que a inexecução resulte de dolo do devedor, as perdas e danos só incluem os prejuízos efetivos e os lucros cessantes por efeito dela direto e imediato, sem prejuízo do disposto na lei processual".

${ }^{255}$ ALVIM, Agostinho, op. cit., p. 370 e seguintes. O autor informa que a fonte inspiradora do legislador brasileiro foi o artigo 1.151 do Código Napoleão, que, por sua vez, reproduziu a doutrina de Dumoulin. Informa ainda que já nas fontes romanas, em um texto de Paulo (D. XIX, 1, L. 21, §3º), é possível visualizála.

${ }^{256}$ Ibid., op. cit., p. 330.

257 O autor exemplifica: "se o comprador, após receber a coisa comprada, verifica que a mesma tem defeito oculto, e, tomando dela, vai ter com o vendedor, a fim de obter outra, e se se dá o caso que, em caminho, é atropelado por um veículo, responderá o vendedor da coisa por êste dano? Não responderá. Mas a razão não se prende ao fato de estar distante êste dano, da causa primeira (a inexecução da obrigação) e sim à interferência de outra causa". Ibid., p. 385.

258 "O ato do credor pode agravar o dano. E por êste novo dano ou gravame não responde o devedor, como é corrente na doutrina. Para encurtar razões, bastará citar a lei de acidentes do trabalho, que, não obstante, definir-se pela responsabilidade objetiva (risco), adota, como regra, a irresponsabilidade do empregador pela agravação do dano, quando oriunda de ação ou omissão da vítima (Dec.-lei $n^{\circ} 7.036$ de 10 de novembro de 1944, art. 13)". Ibid., p. 388.

259 Ibid., p. 396. Veja o exemplo do autor: "Alguém dá em arrendamento uma casa, permitindo a sublocação. Mas o senhorio é vencido, posteriormente, em ação reivindicatória; e o contrato de locação, como conseqüência, deixa de subsistir. Surge, para o locador, a obrigação de indenizar. Seria dano direto do locatário, indiscutìvelmente, a diferença a mais que tivesse que pagar por uma casa semelhante, por ter havido alta de alugueres. Mas, se o locatário subalugasse cômodos e desse pensão, e, por fôrça da rescisão, tivesse que indenizar hóspedes e empregados? Êstes danos, é certo, não se ligam imediatamente à primeira causa. Todavia, como para seu aparecimento não concorreu nenhuma outra causa, a consequiência é que o dano será indenizável, dada a absoluta ligação entre a primeira causa e o último dano. Ibid., p. 389-390.

${ }^{260}$ NORONHA, Fernando, op. cit., p.606. 
danos causados por inadimplemento obrigacional, o que se percebe não só por sua topografia no Código Civil de 2002, mas também e, principalmente, pela redação do artigo 403, que expressamente menciona o inadimplemento ${ }^{261}$.

Realmente, seguindo a distinção metodológica proposta por Menezes Cordeiro $^{262}$, não há como concordar com que a teoria do dano direto e imediato, destinada à imputação de danos oriundos de inadimplemento obrigacional, possa, sem prejuízo sistemático, ser aplicada à seara tão distinta como a da responsabilidade aquiliana.

Pensa-se que qualquer esforço dogmático tendente a impor uma só teoria causal a todo o complexo campo da responsabilidade aquiliana estará fadado ao fracasso em razão do dinamismo inegável da sociedade, que impõe aos julgadores soluções diária para, cada vez mais, variadas formas de causação de danos injustos.

Talvez não tenha sido sem razão que nossos legisladores de ontem e de hoje hajam deixado em aberto a questão do estabelecimento do liame causal na responsabilidade extraobrigacional, conferindo ao julgador certa discricionariedade na sua fixação.

Ao menos no Brasil, a doutrina já reconheceu que a solução jurisprudencial de estabelecimento do nexo causal é tópica, variando, não só de tribunal para tribunal, como de caso para caso $^{263}$, o que talvez venha servindo de estímulo para que os doutrinadores, deixando de lado a busca por solução única, enriqueçam o campo

${ }^{261}$ SILVA, Rafael Peteffi da, Responsabilidade civil pela perda de uma chance: uma análise do direito comparado e brasileiro, São Paulo, Atlas, 2007, p. 26.

${ }^{262}$ Analisada no capítulo 1 desta dissertação (n. r. 50).

263 SCHREIBER, Anderson, op. cit., 2009. No âmbito do Superior Tribunal de Justiça, por exemplo, encontram-se julgados (REsp 858.511/DF, REsp 843.060/RJ, REsp 1.154.737/MT) em que se afirma, fazendo-se referência ao RE 130.764/PR, julgado pelo Supremo Tribunal Federal em 12/05/1992, que a teoria adotada pelo sistema jurídico brasileiro é a teoria do dano direito e imediato, a qual se aplica não só à responsabilidade civil contratual, mas também à extracontratual, inclusive à objetiva. Contudo, a questão é confusa. No RE 858.511/DF, julgado em 19/08/2008, o Ministro Teori Albino Zavascki, em seu voto, afirma que: "Sobre nexo causal em matéria de responsabilidade civil - contratual ou extracontratual, objetiva ou subjetiva - vigora, no direito brasileiro, um princípio (denominado, por alguns, de princípio de causalidade adequada e, por outros, princípio do dano direito e imediato) cujo enunciado pode ser decomposto em duas partes: a primeira (que decorre, a contrario sensu, do art. 159 do CC/16 e do art. 927 do CC/2002, - Caio Mario da Silva Pereira, "Responsabilidade Civil", $7^{a}$ ed., Forense, p. 76 - e que fixa a indispensabilidade do nexo causal), segundo a qual ninguém pode ser responsabilizado por aquilo a que não tiver dado causa; e a outra (que decorre do art. 1.060 do CC/16 e do art. 403 do CC/2002 e que fixa o conteúdo e os limites do nexo causal) segundo o qual somente se considera causa o evento que produziu direta e concretamente o resultado danoso". 
informacional do Direito com novas teorias, como a moderna teoria do escopo da norma violada $^{264}$.

Sucintamente, pode-se, com Menezes Cordeiro, entender a aplicação desta teoria a partir do seguinte esquema: o intérprete verificará qual a norma (entenda-se regime jurídico) incide sobre dada situação concreta e em seguida desvendará quais são os bens jurídicos por ela tutelados. Em sequência, investigará se a conduta sob análise violou a norma e atingiu os bens jurídicos por ela tutelados, valendo-se, para tanto, da velha conditio sine qua non. Se a resposta for afirmativa, caracteriza-se o dano injusto e surge a obrigação de indenizar; do contrário, não ${ }^{265}$.

Conclui-se de todo o exposto que a situação de incerteza quanto à qual teoria aplicar deve ser substituída pela certeza empírica de que não há resposta correta, pois todas as teorias revelam-se, em algum ponto, insuficientes a fornecer solução satisfatória para as diversas hipóteses de situações jurídicas em que a responsabilização civil faz-se sentir.

\subsubsection{Causas de exclusão do nexo causal. Distinção entre exclusão e não formação do nexo causal}

Como afirmado, a causalidade não surge da mera sucessão temporal de fatos, sendo fundamental a intervenção da razão para, a partir desses dados, formar as relações causais ${ }^{266}$.

Ao se pensar no Direito, há de ter-se em mira que se trata de realidade cultural, formada axiologicamente, como inequivocamente demonstrou Miguel Reale ao longo de sua obra filosófica ${ }^{267}$. É, então, submetendo os elementos (dados) a valorações

\footnotetext{
${ }^{264}$ Entre nós pioneiramente adotada por Patrícia Faga Iglecias Lemos. Meio Ambiente e responsabilidade civil do proprietário - análise do nexo causal, São Paulo, Revista dos Tribunais, 2008.

${ }^{265}$ CORDEIRO, António Menezes, Tratado de direito civil português, v. II - Direito das Obrigações, Tomo III - Gestão de negócios, enriquecimento sem causa, responsabilidade civil, Coimbra, Almedina, 2010, p. 537 e seguintes.

266 Nesse sentido, vide também Lourival Vilanova, Causalidade e relação no direito, $4^{\mathrm{a}}$ ed. revista, atualizada e ampliada, São Paulo, Editora Revista dos Tribunais, 2000, especialmente, p. 59 e seguintes.

${ }^{267}$ Especialmente: Fundamentos do direito, $2^{\mathrm{a}}$ ed., São Paulo, Revista dos Tribunais, 1972; O Direito como experiência: introdução à epistemologia jurídica, $2^{\mathrm{a}}$ ed., $4^{\mathrm{a}}$ tiragem, São Paulo, Saraiva, 2010; Teoria
} 
guiadas pelo vetor axiológico justiça, que o jurista construirá as relações jurídicas de causalidade $^{268}$ - no caso desta dissertação -, a fim de determinar a quem cabe a responsabilidade pela causação de certo resultado valorado negativamente.

Quando no subitem 3.4.1 desta dissertação demonstrou-se a relação entre os planos ôntico e deôntico, afirmou-se que o Direito pode comportar-se de, pelo menos, três maneiras distintas em relação à causalidade natural, isto é, utilizando-a, ignorando-a ou, de certa maneira, criando-a, fornecendo-se como exemplo da segunda maneira a chamada culpa exclusiva da vítima.

Ora, no momento em que se passa a ter clareza da independência, ainda que relativa, do Direito em relação ao natural, as hipóteses de não formação e de exclusão do nexo causal impõem-se como evidência lógica.

Partindo-se da estrutura elementar da relação causal, tem-se que é formada do seguinte modo: como dado necessário, dois ou mais termos em sequência temporal; como construído, a seleção axiologicamente dirigida destes termos dentre os sem-número de outros possíveis. A partir dessa seleção, o que era mera relação entre anterior e posterior recebe a qualificação de relação de antecedente e consequente, isto é, de relação causal.

Com relação a não formação do nexo causal, verificar-se-á sempre que faltar a sequência temporal entre os termos ou, sempre que, sobre os termos, ainda que em sequência temporal, não incidir seleção axiologicamente dirigida a que se aludiu.

Assim, não se poderá falar em relação causal se: (i) o termo que se pretende consequente ocorreu antes do termo que se pretende antecedente; ou (ii) se a relação temporal de antecedente e subsequente é não valorada.

tridimensional do direito: preliminares históricas e sistemáticas, $3^{\mathrm{a}}$ ed. revista e atualizada, São Paulo, Saraiva, 1980.

268 Apenas para simples exemplo, pense-se nas relações parentais formadas pela socioafetividade: excetuada a adoção, até bem pouco tempo atrás o Direito valorava apenas dados biológicos para fixação da parentalidade. Graças a alterações axiológicas, hoje, o Direito reconhece a possibilidade de formação de vínculos parentais sem fonte (dados) biológica, e sim com base na chamada afetividade. Note-se que esta alteração operou-se por meio de novo recorte na realidade, isto é, em vez de considerar (valorar) os dados biológicos, passou a considerar dados sociológicos. 
Com relação a (i), uma conduta posterior à causação de um dano, por motivos lógicos, jamais pode ser considerada sua causa.

Já com relação a (ii), exige-se análise mais detida porque a sequência temporal entre os eventos pode levar a erro. Imagine-se que em uma praça várias crianças, acompanhadas de seus pais, estão a brincar de pega-pega, quando, então, duas delas se chocam, e uma delas sofre um profundo corte na testa. Inequivocamente, o choque é antecedente temporal do dano, mas não há entre eles relação jurídica de causalidade e, portanto, não surge qualquer obrigação de indenizar. Não há relação jurídica de causalidade porque, para a hipótese imaginada, a conduta fisicamente causadora do dano é inidônea para ser causa jurídica do dever de indenizar por lhe faltar culpa, no caso, o fator de seleção axiológica dos termos.

As chamadas causas de exclusão do nexo causal pressupõem a ocorrência de ato ou fato que, ao se intrometer na sequência de um desdobramento causal, atrai para si a causação do resultado.

Percebe-se neste tema toda a força da experiência no Direito. Isso porque só se fala em causa de exclusão do nexo quando o desdobramento causal que, segundo as máximas de experiência, seria idôneo a ser considerado causa jurídica de evento lesivo é interrompido por ato ou fato que, então, passa a ser considerado o único causador do dano.

Imagine-se a conduta do motorista de trafegar com seu veículo por via pública. Essa conduta é, segundo máximas de experiência, apta a ser causa jurídica da causação de dano decorrente de atropelamento. Agora se, após o desencadeamento da série causal, isto é, iniciada a conduta de conduzir o veículo, um terceiro empurrar alguém na frente do veículo, ter-se-á de considerar responsável pelo dano, não o motorista, e sim este terceiro.

Dessa forma, a partir do quod plerumque fit, os cientistas do Direito elegem os atos e fatos capazes de atrair a causação jurídica do evento lesivo e passam a qualificálos de causas de exclusão do nexo causal. Deste labor científico, aproveitado pelos legisladores e julgadores, generalizaram-se como causas de exclusão do nexo causal o ato exclusivo da vítima ou de terceiro, o caso fortuito e a força maior. 
Justamente por serem produtos da racionalidade humana, e não imposições naturalísticas, é que estas causas de exclusão do nexo causal não são rígidas, mas, ao contrário, amoldam-se segundo vetores axiológicos, permitindo, por exemplo, que a jurisprudência ou a lei afastem a alegação de causas de exclusão do nexo em certas hipóteses de desdobramento causal, por exemplo: a impossibilidade do transportador de pessoas alegar ato exclusivo de terceiro para livrar-se do dever de indenizar danos sofridos pelos passageiros ${ }^{269}$ ou, em sede de dano ambiental, a impossibilidade de alegar-se força maior.

${ }^{269}$ Artigo 735 do Código Civil, que reproduziu o teor da súmula 187 do Supremo Tribunal Federal. 


\section{CAPÍTULO 4 - DESCONSTRUÇÃO DA ESTRUTURA CLÁSSICA DA RESPONSABILIDADE CIVIL?}

\subsection{Considerações iniciais}

A responsabilidade civil, entendida como mecanismo sistêmico de anatematização de danos injustos, é estruturada a partir de elementos que a dogmática qualifica como pressupostos - conditiones sine quibus non - para a deflagração da responsabilização civil.

Embora historicamente sempre se tenha exigido alguma estrutura fundamental, mais ou menos complexa, para imputar a alguém o dever de indenizar o dano injusto sofrido por outrem, é a partir das grandes codificações, conforme analisado, que tais elementos tornam-se constantes. Com efeito, o ato ilícito, a culpa, o dano e o nexo de causalidade passaram a ser imprescindíveis para deflagração da responsabilização civil ${ }^{270}$.

Porém, as transformações verificadas na sociedade, em razão de vários fatores, impuseram ao Direito a necessidade de adaptar-se às novas demandas sociais, o que vem realizando, também, por meio do que se entende ser flexibilização da estrutura de responsabilização civil.

Parcela da doutrina brasileira, contudo, influenciada por autores estrangeiros, passou a defender que a estrutura atual de responsabilização civil deve ser ou, ao menos, tende a ser substituída por um "direito de danos"271.

O fundamento lançado pelos defensores dessa nova tendência para justificar essa substituição - e que deve justificar toda e qualquer ruptura com dado modelo

${ }^{270}$ CORDEIRO, António Menezes, Tratado de direito civil português, v. II - Direito das Obrigações, Tomo III - Gestão de negócios, enriquecimento sem causa, responsabilidade civil, Coimbra, Almedina, 2010, p. 318 e seguintes.

${ }^{271}$ Por exemplo, Teresa Ancona Lopez, Princípio da precaução e evolução da responsabilidade civil, São Paulo, Quartier Latin, 2010; Daniel de Andrade Levy, Responsabilidade civil: de um direito dos danos a um direito das condutas lesivas, São Paulo, Atlas, 2012; Lucas Abreu Barroso e Pablo Malheiros da Cunha Frota, A obrigação de reparar por danos resultantes da liberação do fornecimento e da comercialização de medicamentos, in Revista Trimestral de Direito Civil, ano 11, v. 43, julho a setembro de 2010, p. 99-114. 
científico - é o de que a estrutura atual de responsabilização civil é insuficiente para atender aos anseios por proteção de uma população que vive diuturnamente sob risco de sofrer danos.

O novo modelo científico que se pretende fazer substituir à atual estrutura de responsabilização civil seria apto a satisfazer a demanda social por mecanismos de proteção contra "danos potenciais",272, daí já se ter falado em "direito das condutas lesivas",273.

Este capítulo cumprirá dois objetivos: analisar sumariamente os principais fatores que levaram à transformação social mencionada e seus reflexos na estrutura atual de responsabilidade civil e demonstrar que muitas das inovações propostas por parte da doutrina não são coerentes, do ponto de vista sistemático, com o instituto da responsabilidade civil. Com isso, restará confirmada a eficiência da atual estrutura de responsabilidade civil para atender à finalidade a que se destina: a reparação de danos.

\subsection{Os fatores da transformação social e seus reflexos na responsabilidade civil}

Segundo Geneviève Viney, as mudanças ocorridas no mundo contemporâneo devem-se, basicamente, às inovações tecnológicas, à evolução das práticas e das estruturas econômicas e às ideologias sociais ${ }^{274}$.

O desenvolvimento do maquinismo, que teve lugar com a Revolução Industrial, na segunda metade do século XVIII, substituiu aquela sociedade essencialmente agrícola e artesanal por uma sociedade industrial e urbana, marcada pelo desenvolvimento dos transportes (ferroviário, rodoviário e aéreo), visando ao deslocamento da população, bem como ao escoamento da produção e à importação de matéria-prima; pela alteração das

\footnotetext{
${ }^{272}$ Expressão utilizada, por exemplo, por Lucas Abreu Barroso e Pablo Malheiros da Cunha Frota. A obrigação de reparar por danos resultantes da liberação do fornecimento e da comercialização de medicamentos, in Revista Trimestral de Direito Civil, ano 11, v. 43, julho a setembro de 2010, p. 99-114.

${ }^{273}$ Daniel de Andrade Levy, Responsabilidade civil: de um direito dos danos a um direito das condutas lesivas, São Paulo, Atlas, 2012.

${ }^{274}$ VINEY, Geneviève, As tendências atuais do direito da responsabilidade civil, tradução de Paulo Cezar de Mello, in Direito Civil Contemporâneo: novos problemas à luz da legalidade constitucional: anais do Congresso Internacional de Direito Civil-Constitucional da cidade do Rio de Janeiro, organizador TEPEDINO, Gustavo, São Paulo, Atlas, 2008, p. 42-56.
} 
relações de trabalho, com a submissão dos trabalhadores à prática de atividades perigosas, a longas jornadas, a ambientes insalubres; pela formação de empresários do capitalismo produtivo; e pela produção em massa ${ }^{275}$.

Nesta sociedade, apareceram novos acidentes, mais graves e em maior escala - como os acidentes do trabalho e os acidentes de transporte -, para os quais a responsabilidade subjetiva, assentada na teoria da culpa, mostrou-se insatisfatória ${ }^{276}$. As vítimas, geralmente, não conseguiam fazer prova do elemento culpa. Isso se dava, sobretudo, em razão da complexidade técnica de produção dessa prova, bem como da hipossuficiência econômica das vítimas ${ }^{277}$. Ademais, não raras vezes, elas não conseguiam sequer identificar o autor da conduta culposa que deu origem ao dano ${ }^{278}$.

Em um primeiro momento, houve a criação de presunções de culpa, as quais implicam inversão do ônus da prova. Assim, o empregador e o transportador eram presumidos culpados, cabendo-lhes provar que não agiram culposamente. Isso, é claro, facilitou a indenização das vítimas. No Brasil, por exemplo, o Decreto $\mathrm{n}^{\circ} 2.681$, de 7 de dezembro de 1912, no seu artigo 17, estabeleceu presunção de culpa do transportador ferroviário, vindo, mais tarde, a jurisprudência estender a aplicação deste dispositivo também para os casos de acidentes em transporte rodoviário e urbano ${ }^{279}$.

Posteriormente, consagrou-se, finalmente, a responsabilização civil objetiva, assentada na doutrina do risco, em suas várias vertentes (risco proveito, risco criado, risco profissional), admitindo-se, então, em determinadas situações, o surgimento do dever de indenizar independentemente de culpa ${ }^{280}$.

${ }^{275}$ MORSELLO, Marco Fábio, Responsabilidade civil no transporte aéreo, São Paulo, Atlas, 2006, p. 3.

${ }^{276}$ VINEY, Geneviève, op. cit., p. 42; 45-46.

${ }^{277}$ MORSELLO, Marco Fábio, op. cit., p. 4.

${ }^{278}$ VINEY, Geneviève, op. cit., p. 42.

279 MORSELLO, Fábio Mário, op. cit., p. 5-7. O autor lembra que muitos doutrinadores brasileiros entendem que esse dispositivo prevê hipótese de responsabilidade objetiva do transportador e não de mera presunção de culpa.

${ }^{280}$ MORSELLO, Marco Fábio, ibid., p. 5. Atualmente, reitere-se, no ordenamento jurídico brasileiro, o parágrafo único do artigo 927 do Código Civil estabelece que a reparação do dano independe de culpa quando a lei expressamente o disser (por exemplo, artigo 14, §1 ${ }^{\circ}$, da Lei 6.938/1981; artigos 12, 14, 18 e 19 da Lei 8.078/1991; artigo 37, $\$ 6^{\circ}$, da Constituição Federal) ou quando a atividade normalmente desenvolvida pelo autor do dano implicar, por sua natureza, riscos para os direitos de outrem. Nesta última parte do dispositivo, encontra-se consagrada uma cláusula geral de responsabilidade objetiva. Cf.: Claudio Luiz Bueno de Godoy, Responsabilidade civil pelo risco da atividade: uma cláusula geral no Código Civil de 2002, $2^{a}$ ed., Coleção Professor Agostinho Alvim, coordenação Renan Lotufo, São Paulo, Saraiva, 2010. 
Paralelamente, também surgiram os regimes de reparação socializada, independentes da responsabilidade civil $^{281}$. É a chamada socialização dos riscos. Trata-se de técnica de socialização da reparação de danos cuja finalidade é facilitar a indenização das vítimas. Daí porque se diz que a terminologia empregada não é muito adequada, porque, em verdade, não é propriamente o risco que é socializado, mas, sim, a reparação de suas consequências danosas ${ }^{282}$.

Afirma-se que a socialização dos riscos está afinada com os anseios da sociedade contemporânea, que rejeita a fatalidade e que exige, cada vez mais, segurança ${ }^{283}$ :

"Esta exigência gera a convicção de que qualquer risco deve ser coberto, que a reparação de qualquer dano deve ser rápida e integral e a sociedade deve prover, por isso, não somente uma indenização dos danos que ela própria gerou, como também aqueles que não conseguiu impedir ou que não soube prever a ocorrência" ${ }^{284}$.

A ideia é a de que, nessa sociedade, existem riscos em relação aos quais as vítimas não dispõem de meios para precaver-se e não é justo que tenham de suportar as consequências lesivas desses riscos individualmente. Assim sendo, a solidariedade social impõe, então, a divisão dos prejuízos ${ }^{285}$.

Diz-se que:

\begin{abstract}
"há socialização do risco quando a indenização das consequências danosas de um risco não tem nenhuma ligação com a responsabilidade ou quando o financiamento desta indenização está, a priori ou a posteriori, desconectado de
\end{abstract}

\footnotetext{
${ }^{281}$ VINEY, Geneviève, op. cit., p. $42-43$ e 46-47.

${ }^{282}$ Responsabilidade e socialização do risco, considerações gerais de relatório público do Conselho de Estado da França, tradução de Michels Abes, Brasília, UniCEUB, 2006, p. 9.

${ }^{283}$ Idem.

${ }^{284}$ Idem.

285 Ibid., p. 10. No ordenamento jurídico pátrio, a solidariedade social constitui um dos objetivos fundamentais da República Federativa do Brasil, nos termos do disposto no artigo $3^{\circ}$, inciso I, da Constituição Federal.
} 
cotizações ou retiradas individuais, ou ainda, quando o poder público está implicado nesta indenização, até na falta de responsabilidade direta num dano" 286 .

Criam-se, então, seguros obrigatórios, fundos estatais ou fundos mistos, formados por reservas públicas e privadas, estas, geralmente, de empresas que desenvolvem atividades de risco.

No Brasil, a Lei 6.194, de 19 de dezembro de 1974, criou o seguro obrigatório dos proprietários de veículos automotores (DPVAT), assegurando uma indenização mínima às vítimas de acidentes envolvendo veículos automotores. Também para os acidentes do trabalho, as Leis 8.212 e 8.213, ambas de 24 de julho de 1991, preveem um seguro coletivo, mantido por contribuições tributárias pagas pelos empregadores e cujas alíquotas variam de acordo com o grau de risco da atividade desenvolvida.

É importante deixar claro que a socialização dos riscos não importa extinção da responsabilidade civil $^{287}$. Tratam-se de institutos que se somam e que convivem harmonicamente no sistema com a finalidade de reparar danos, porém, cada qual a seu modo.

Enquanto a responsabilidade civil preocupa-se com a origem do dano, determinando que a obrigação de indenizar somente seja imposta a alguém que possa ser qualificado como responsável pela causação do dano, a socialização dos riscos opera por meio de contratos ou programas governamentais, bastando, para que se faça jus à indenização, que se comprove ter a vítima sofrido dano coberto, pouco importando quem seja o causador do dano.

A socialização dos danos surge da necessidade de conferir-se às vítimas uma rápida reparação, mas, não obstante, permite as ações regressivas contra o agente causador do dano $^{288}$, o que se dá por meio da estrutura de responsabilização civil ${ }^{289}$.

\footnotetext{
${ }^{286}$ Idem.

${ }^{287}$ Ibid., p. 11.

${ }^{288}$ Idem.
} 
O grande debate existente hoje sobre a socialização dos riscos diz respeito ao fato de sua aplicação poder reduzir a adoção de medidas que previnam a ocorrência de danos. Daí porque se defende que a socialização dos riscos deve ocorrer concomitantemente com emprego de técnicas de gerenciamento de riscos de danos, embasadas nos princípios da prevenção e precaução, adiante analisados ${ }^{290}$, bem como sem se prescindir das ações regressivas.

Ao lado dessas inovações, o modelo de economia industrial, orientado "para a produção e a distribuição em grande escala de produtos de consumo padronizados"291, fez surgir os danos de massa, que atingem um grande número de pessoas, podendo caracterizar-se, basicamente, como danos seriais de consumo, isto é, "devidos a um produto largamente difundido junto ao público e que se revela defeituoso" ou como danos ambientais $^{292}$. Trata-se de danos que podem assumir a forma de danos $\operatorname{coletivos}^{293}$ ou danos individuais.

A tutela das pessoas frente a esses danos foi impulsionada pela tendência ideológica de proteção dos chamados direitos fundamentais, imbricados com os direitos da personalidade. Nesse sentido, teve especial relevo a "ideologia dos direitos do homem", originada do movimento iluminista, no século XVIII, que culminou numa série de declarações de direitos do homem, como as francesa e norte-americana ${ }^{294}$.

Um dos principais problemas verificados com relação ao ressarcimento desses danos de massa diz respeito à dificuldade em identificar-se o verdadeiro autor do dano, tendo em vista os atuais modelos empresariais adotados - empresas com matriz e

289 Com que se evitará a concretização do receio exposto no relatório do Conselho de Estado da França, que afirma: "Sob pena de desresponsabilização, geralmente, coloca-se a pergunta sobre o lugar que deve conservar ou retomar a responsabilidade nos sistemas de cobertura dos riscos". Idem.

${ }^{290}$ Idem.

${ }^{291}$ VINEY, Geneviève, op. cit., p. 43.

292 Ibid., p. 52.

${ }^{293}$ Pode-se dizer que danos coletivos são aqueles que atingem uma pluralidade de esferas jurídicas. No ordenamento jurídico brasileiro, o artigo 81, parágrafo único, incisos I a III, do Código de Defesa do Consumidor (Lei 8.078/1991) permite a classificação dos danos coletivos em três espécies, conforme atinjam: "I - interesses ou direitos difusos, assim entendidos, (...), os transindividuais, de natureza indivisível, de que sejam titulares pessoas indeterminadas e ligadas por circunstâncias de fato; II - interesses ou direitos coletivos, assim entendidos, (...), os transindividuais de natureza indivisível de que seja titular grupo, categoria ou classe de pessoas ligas entre si ou com a parte contrária por uma relação jurídica base; III - interesses ou direitos individuais homogêneos, assim entendidos os decorrentes de origem comum”.

${ }^{294}$ VINEY, Geneviève, op. cit. p. 44-45. 
filiais, grupos empresariais - e à frequente divisão de determinado mercado entre alguns produtores ou distribuidores $^{295}$.

Além disso, os danos de massa são danos que podem gerar indenizações vultosas, que ultrapassam o patrimônio do agente responsável e que impossibilitam a contratação de seguros de responsabilidade por valores razoáveis ${ }^{296}$.

Discute-se também, com relação a esses danos, a necessidade de adoção de procedimentos específicos para repará-los, tendo em vista que o grande número de vítimas faz surgir inúmeras demandas nos tribunais, sobrecarregando o Judiciário e ensejando a prolação de decisões contraditórias. Além disso, muitas vítimas podem sentir-se desestimuladas em buscar reparação em virtude dos altos custos de uma ação individual ${ }^{297}$.

Foi, sobretudo, em razão dos estudos acerca da reparação dos danos ambientais que se desenvolveram os princípios da prevenção e da precaução. Segundo Édis Milaré, estes são princípios distintos entre si. A prevenção trata de riscos ou impactos já conhecidos pela ciência e seu objetivo é "impedir a ocorrência de danos ao meio ambiente, através da imposição de medidas acautelatórias, antes da implantação de empreendimentos ou atividades consideradas efetiva e potencialmente poluidoras" ${ }^{\text {298 }}$. Por sua vez, a precaução destina-se a gerir riscos ou impactos desconhecidos, de forma que "a ausência de certeza científica absoluta não deve servir de pretexto para procrastinar a adoção de medidas efetivas capazes de evitar a degradação do meio ambiente. Vale dizer, a incerteza científica milita em favor do ambiente, carreando-se ao interessado o ônus de provar que as intervenções pretendidas não trarão cosequências indesejadas ao meio considerado"299.

No Brasil, o princípio da precaução passou para o direito positivo a partir da Eco 92, da qual resultaram dois importantes documentos: a Declaração do Rio e a Convenção sobre Mudança do Clima ${ }^{300}$. O primeiro, no Princípio 15, estabelece: “Com o

\footnotetext{
${ }^{295}$ VINEY, Geneviève, ibid., p. 52-54.

${ }^{296}$ VINEY, Geneviève, idem.

${ }^{297}$ VINEY, Geneviève, ibid., p. 53. Adiante, será retomada a questão sobre se o ordenamento jurídico brasileiro contém, ou não, mecanismos aptos a tutelar os interesses coletivos.

${ }^{298}$ MILARÉ, Édis, Direito do ambiente: a gestão ambiental em foco: doutrina, jurisprudência, glossário, $6^{\text {a }}$ ed. rev., atual. e ampl., São Paulo, Revista dos Tribunais, 2009, p. 823-824.

${ }^{299}$ Ibid., p. 824-825.

${ }^{300}$ Idem. A Declaração do Rio de Janeiro sobre Meio Ambiente e Desenvolvimento não é tecnicamente um tratado internacional. É um documento indicador de condutas futuras que devem ser perseguidas pelos
} 
fim de proteger o meio ambiente, o princípio da precaução deverá ser amplamente observado pelos Estados de acordo com suas capacidades. Quando houver ameaça de danos graves e irreversíveis, a ausência de certeza científica absoluta não será utilizada como razão para o adiamento de medidas economicamente viáveis para prevenir a degradação ambiental”.

Já o artigo $3^{\circ}, 3$, da Convenção sobre Mudança do Clima, dispõe que: “As partes devem adotar medidas de precaução para prever, evitar ou minimizar, as causas da mudança do clima e mitigar seus efeitos negativos. Quando surgirem ameaças de danos sérios ou irreversíveis, a falta de plena certeza científica não deve ser usada como razão para postergar essas medidas (...)".

Alguns dos civilistas que propugnam pela adoção de um novo modelo de responsabilidade civil defendem a incorporação destes princípios nesta seara da dogmática, porém não só para evitar danos, mas para determinar "indenização" quando, a despeito da não ocorrência de danos, haja violação da prevenção ou precaução ${ }^{301}$.

Outros, como Teresa Ancona Lopez, defendem que a violação dos princípios, quando não enseja causação de dano, não autoriza indenização, mas, sim, fundamenta a deflagração de mecanismos que impeçam a realização de danos ${ }^{302}$.

Em ambos os casos, contudo, propugna-se por uma ampliação da função da responsabilidade civil. Ao lado da reparação, também a prevenção de danos.

Também nesta tendência de ampliação da função da responsabilidade civil, vem ganhando espaço no Brasil, já com aceitação jurisprudencial, a tese dos punitive damages ou do valor de desestímulo, segundo a qual o quantum de indenização deve

Estados. Por sua vez, a Convenção sobre Mudança do Clima, também denominada Convenção Quadro das Nações Unidas sobre Mudança do Clima, é um tratado internacional. Ela foi assinada em 09 de maio de 1992 e entrou em vigor, no âmbito internacional, em 21 de março de 1994, 90 dias após ter sido ratificada por 50 signatários. No Brasil, foi aprovada pelo decreto legislativo $\mathrm{n}^{\mathrm{o}} 1$, de 03 de fevereiro de 1994, e promulgada pelo decreto $\mathrm{n}^{\mathbf{o}} 2.652$, de 01 de julho de 1998 .

${ }^{301}$ Nesse sentido, Daniel de Andrade Levy, op. cit., p. 164; Lucas Abreu Barroso e Pablo Malheiros da Cunha Frota, A obrigação de reparar por danos resultantes da liberação do fornecimento e da comercialização de medicamentos, in Revista Trimestral de Direito Civil, ano 11, vol. 43, julho a setembro de 2010, p. 99-114.

${ }^{302}$ LOPEZ, Teresa Ancona, op. cit., p. 119-140. 
abranger valor suficiente para a reparação da vítima e, ainda, para punir o causador do dano.

Os punitive damages surgiram no âmbito do common law e foram introduzidos no Brasil graças à natural indeterminabilidade da extensão do dano não patrimonial. Em determinadas situações em que foi causado dano não patrimonial, argumenta-se que não seria suficientemente restabelecido o equilíbrio social sem que, ao lado da reparação, fosse punido o causador do dano ${ }^{303}$. Uma vez admitidos os punitive damages em sede de dano não patrimonial, a doutrina não tardou a tentar estendê-los aos danos patrimoniais ${ }^{304}$.

Assim sendo, o atual cenário é o da defesa de três funções da responsabilidade civil: reparadora, preventiva e punitiva. Parece que esta ampliação é o conteúdo do que se convencionou chamar "direito de danos", tendência sistematicamente inconsistente, como se passa a demonstrar.

\subsection{As alterações nos pressupostos da responsabilidade civil}

Como o cerne dessa dissertação está diretamente relacionado com a análise das atuais propostas doutrinárias que em maior ou menor intensidade buscam alterar o papel do dano na estrutura da responsabilidade civil, optou-se por inverter a ordem de análise dos elementos da responsabilidade civil, antecipando o exame do nexo causal e deixando para o final o exame do dano.

\footnotetext{
${ }^{303}$ Cf., por exemplo, no STJ: REsp 1.181.395/SC, julgado em 20/04/2010, $2^{\text {a }}$ Turma, relator Ministro Humberto Martins. No seu voto, o relator afirma que: "Não resta dúvida, no presente caso, que o proprietário do veículo sofreu desconforto e constrangimento bastantes para se impor uma compensação pelo infortúnio, que deve ter finalidade compensatória e punitiva, sem patrocinar o enriquecimento sem causa”. Ver também: REsp 1.171.826/RS, julgado em 17/05/2011, Terceira Turma, relatora Ministra Nancy Andrighi. Neste julgado, a Ministra relatora afirma: "Não obstante isso, muito excepcionalmente o quantum arbitrado tem sido modificado se a Corte identifica ausente qualquer das seguintes funções: (i) a proporcionalidade da compensação em relação ao sofrimento; (ii) a exemplaridade da punição do ofensor para evitar novo ato danoso". E ainda: AgRG no AResp 148.113/SP, julgado em 26/06/2012, Terceira Turma, relator Ministro Sidnei Beneti.

${ }^{304}$ Nesse sentido, por exemplo, Daniel de Andrade Levy, op. cit. 116-117 e 252.
} 


\subsubsection{A conduta}

Como já afirmado anteriormente ${ }^{305}$, só há possibilidade de imputar-se responsabilidade pela causação de dano injusto a um sujeito de direito, daí a necessidade inafastável de haver conduta de alguém para que surja o dever de indenizar.

No entanto, a conduta, elemento da estrutura de responsabilização civil, vem sofrendo esvaziamento axiológico, mormente a partir da consagração da responsabilidade objetiva, isto é, daquela que se configura independentemente de culpa.

Este esvaziamento axiológico da conduta é resultado de nova valoração do papel social da responsabilidade civil. Até o efetivo reconhecimento da possibilidade de responsabilizar alguém independentemente da aferição de culpa, à responsabilidade civil era atribuída a função de sancionar condutas descuidadas capazes de romper o equilíbrio social. Assim, ao lado da responsabilização penal, a responsabilidade civil funcionava como instrumento jurídico de reprovação de comportamentos antissociais, notando-se, claramente, que a personagem central da responsabilização (civil ou penal) era o causador do dano.

Mas, em decorrência dos diversos fatores sociais já apontados, vem ocorrendo uma inequívoca alteração do polo de interesse da responsabilidade civil, que migrou do realizador da conduta para a vítima do dano injusto.

Esta viragem caracteriza-se por impor ao intérprete novo vetor axiológico de análise da responsabilidade civil, é dizer, ele passou a ter de perguntar-se não se a conduta foi culposa, mas, sim, se é justo, ou injusto, a vítima arcar com o prejuízo que experimentou.

É justamente esta mudança de perspectiva que também possibilita a existência coerente do ponto de vista sistemático de hipóteses de responsabilização civil deflagradas por condutas lícitas, além das clássicas causas de exclusão da ilicitude ${ }^{306}$.

\footnotetext{
${ }^{305}$ Cf.: capítulo 3.

306 Judith Martins-Costa aponta como exemplos de responsabilização civil por ato lícito "a responsabilidade por danos da Administração Pública, em virtude do princípio da igual repartição das cargas
} 
Ademais, o Código Civil brasileiro de 2002 trouxe inovação bastante relevante acerca do papel da conduta do responsável nos casos de responsabilidade civil por ato de terceiro. Com efeito, até o advento do atual Código Civil, era imprescindível que o responsável atuasse com culpa para que respondesse pelo ato de terceiro ${ }^{307}$.

Atualmente, até por força de dispositivo expresso ${ }^{308}$, os pais, tutores, curadores, empregadores e titulares de hospedarias respondem objetivamente pelos atos culposos daqueles arrolados no artigo 932, incisos I a IV, do Código Civil. É dizer, constatada a conduta culposa causadora de dano injusto por parte, por exemplo, do filho menor sob guarda e companhia dos pais, estes responderão objetivamente pela reparação civil.

A diferença em relação ao sistema anterior é evidente: eram necessárias duas condutas culposas para que surgisse o dever de indenizar, quais sejam a do dependente e a do responsável, enquanto que, hoje, basta apenas a conduta do dependente, que poderá, conforme a hipótese de responsabilidade civil, depender ou não de culpa ${ }^{309}$.

Esta alteração permite hipóteses de responsabilização não por conduta, mas por mera posição jurídica. Os sujeitos arrolados como responsáveis pelo artigo 932 do Código Civil, que antes eram responsabilizados quase que como coautores do dano injusto, passaram a responder como meros garantes da vítima, isto é, independentemente de qualquer valoração negativa de suas posturas diante do sinistro.

Vê-se, pois, que, embora seja necessária conduta para deflagração da estrutura de responsabilização civil, casos há em que o dever de reparar o dano injusto é atribuído a quem não agiu nem se omitiu.

públicas", e, especificamente no Direito Civil, as hipóteses dos artigos 188, incisos I e II, combinado com os artigos 929, 930 e também artigos 1.285, 1.286, 1.289, 1.291, 1.292, 1.293, 1.311, parágrafo único, 1.385, parágrafo $3^{\circ}$ e ainda as hipóteses de responsabilidade objetiva fundada no princípio da segurança social. Comentários ao novo Código Civil, vol. V, tomo II: do inadimplemento das obrigações, arts. 389 a 420, coordenador TEIXEIRA, Sálvio de Figueiredo, Rio de Janeiro, Forense, 2004 coordenador Sálvio de Figueiredo Teixeira, Forense, Rio de Janeiro, 2004, p. 124, n.r. 100.

307 Ainda que, nos últimos anos, doutrina e jurisprudência tenham estabelecido a prevalência da presunção de culpa.

${ }_{308}^{308}$ Artigo 933 do Código Civil.

${ }^{309}$ No caso, por exemplo, de o menor praticar dano ambiental, está-se diante de responsabilidade civil objetiva. 
Outra importante consequência do esvaziamento axiológico da conduta para fins de responsabilização civil é a possibilidade de responsabilização direta do incapaz quando seus representantes não tenham a obrigação de fazê-lo ou não disponham de meios para tanto, e, desde que a responsabilização civil não o prive, ou, os que dele dependam, do necessário a uma existência digna (artigo 928 do Código Civil).

Essa possibilidade é perfeitamente condizente com o sistema de responsabilidade civil, pois a finalidade a que se destina é a reparação de danos, e não a punição do seu causador. Qualquer punição só tem sentido quando aplicada a alguém que tenha capacidade de entender o caráter reprovável de seu comportamento, o que, à evidência, não é o caso dos incapazes ${ }^{310}$. Por sua vez, a reparação exige apenas a existência de um patrimônio suficiente à recomposição da esfera jurídica da vítima ao statu quo ante.

\subsubsection{O nexo de causalidade}

O nexo de causalidade, entendido como a ligação normativa entre conduta e dano, é imprescindível para que haja responsabilização civil de alguém ${ }^{311}$. No entanto, a caracterização do nexo de causalidade é extremamente complexa, principalmente, pela ausência de uniformidade de seu tratamento em doutrina e em jurisprudência ${ }^{312}$. Mas esta ausência de uniformidade não é simplesmente quantitativa, vale dizer, não se dá apenas porque cada tribunal adota uma dada teoria; ao contrário, ela, a par de quantitativa, é qualitativa na medida em que os tribunais não demonstram coerência decisória, decidindo

\footnotetext{
${ }^{310}$ Sobre a responsabilização civil do incapaz e na linha do que aqui se expôs, José Fernando Simão ensina que: "A criação [do sistema de responsabilidade do incapaz] deu-se de maneira inédita na História do Direito brasileiro, porque se estima a responsabilidade pessoal e direta do incapaz, mas de maneira subsidiária. De início, a responsabilidade integral recai sobre os representantes legais, independentemente de sua culpa. É a teoria do risco na modalidade dependência. O abandono do vínculo, até então existente entre imputabilidade e culpabilidade, revela o interesse do legislador em garantir indenização à vítima, rompendose com princípios seculares pelos quais, inexistindo imputabilidade, a noção do certo ou do errado, o causador do dano não poderia ser responsabilizado". Responsabilidade civil do incapaz, São Paulo, Atlas, 2008, p. 249-250.

${ }^{311}$ Os autores que, como Fernando Noronha, entendem ser possível responsabilidade civil sem nexo de causalidade confundem nexo de causalidade com causalidade física, como amplamente demonstrado capítulo 3 dessa dissertação.

${ }^{312}$ Como já apontado, existem várias teorias que buscam fornecer aos julgadores os critérios para selecionar os dados fenomênicos e, com isso, verificar se, no caso sob análise, está ou não presente o nexo de causalidade.
} 
cada caso a partir de teoria diversa, inviabilizando, assim, qualquer tentativa de sistematização ${ }^{313}$.

Em parte, isso se explica porque, em alguns casos concretos, é muito difícil ou mesmo impossível verificar a existência do nexo de causalidade, o que impõe ao Judiciário certa discricionariedade no estabelecimento do nexo, sob pena de, não o fazendo, inviabilizar a reparação dos danos.

Essa postura jurisprudencial inegavelmente tópica acabou por gerar na doutrina o anseio de fornecer modelos decisórios que permitam alguma previsibilidade quando do julgamento de questão em que o estabelecimento do nexo causal revele-se muito difícil.

Assim, vêm surgindo teorias várias cujo objetivo final é permitir - ou melhor, legitimar - o julgador a presumir a existência de nexo de causalidade em certas hipóteses, é o que ocorre, por exemplo, quando o dano é causado por membro não identificado de um grupo $^{314}$.

${ }^{313}$ Por todos, veja-se Anderson Schreiber que, com base em doutrina italiana, fala em nexo causal flexível. Op. cit., p. 64.

${ }^{314}$ Sobre o tema, veja-se a obra exaustiva de Gisela Sampaio da Cruz, O problema do nexo causal na responsabilidade civil, Rio de Janeiro, Renovar, 2005, principalmente página 267 e seguintes.

A autora analisa a chamada causalidade alternativa, citando, dentre outros, o caso ocorrido na cidade de Flores da Cunha, durante a $1^{\mathrm{a}}$ Festa da Vindima: "Durante o desfile, uma pessoa foi gravemente ferida por um disparo de arma de fogo que partiu do carro alegórico denominado 'Os Caçadores'. Os integrantes desse carro portavam espingardas de caça e carregavam uma gaiola com pombos a serem soltos e alvejados diante do palanque oficial. Efetuariam, porém, apenas disparos com balas de festim, utilizando, em vez de chumbo, confete. Ocorre que um dos integrantes, não identificado, disparou, durante o desfile, balas de verdade que atingiram um espectador no rosto e no tórax, causando-lhe perda de visão e problemas pulmonares. Nenhum dos caçadores que ali desfilavam assumiu a autoria do fato. Por falta de prova, foram todos absolvidos na esfera criminal. A vítima, então, intentou uma única ação indenizatória em face de todos os que ocuparam o mencionado carro alegórico. Em $1^{\mathrm{a}}$ instância [AC 11.1195, $1^{\text {a }}$ Câmara Cível do Tribunal de Justiça do Rio Grande do Sul, relator Desembargador Oscar Gomes Nunes, julgado de 25/11/1970], a responsabilidade solidária foi afastada, sob o fundamento de que 'a condenação só poderia recair na pessoa do verdadeiro culpado'. O Tribunal de Justiça do Estado do Rio grande do Sul, mais uma vez reconhecendo a causalidade alternativa, reformou a decisão a quo, ao considerar '(...) solidária a responsabilidade, muito embora só um tenha sido o causador do dano, pois o fato decorreu da falta do dever de vigilância, na guarda de coisa perigosa e que a todos competia zelar'. Referindo-se a esse dever de vigilância, afirmou o Desembargador Oscar Gomes Nunes, relator do processo: 'Todos, evidentemente, falharam no cumprimento daquele dever e só isso bastaria para que, solidariamente, respondessem pelo pagamento da indenização"'. E observa a autora: "Nessa decisão, enfrentou-se o problema da causalidade alternativa, ainda que se tenha usado como fundamento para a condenação a teoria da guarda. Não obstante se ignorar quem desfechou o tiro que veio a cegar a vítima, todos os possíveis autores, que se encontravam em um círculo restrito de pessoas, foram considerados responsáveis solidários". Op. cit., p. 298-299. 
Vê-se, pois, que o que vem ocorrendo hoje em sede de responsabilidade civil e, mais especificamente, no estabelecimento do nexo de causalidade é a utilização do pensamento conjetural, tal como desenvolvido entre nós por Miguel Reale ${ }^{315}$, que permite substituir os juízos de certeza, muitas vezes inalcançáveis, por juízos de plausibilidade.

O juízo conjetural pode perfeitamente ser utilizado desde que com respeito aos vetores axiológico-chave do sistema jurídico, ou seja, naqueles campos em que não se exija juízo de certeza. Com efeito, em ramos normativos funcionalizados à punição, como são o penal e o administrativo disciplinar, não há espaço para conjetura, a não ser para absolver, pois que o valor-chave é a liberdade, protegida pela presunção de inocência.

Ora, desde que a responsabilidade civil funcionalizou-se em busca da indenização da vítima de dano injusto, deixando em segundo plano a sanção ao causador do dano, abriu-se espaço ao juízo conjetural, no qual imperam presunções com base nas máximas de experiência, o que explica o fenômeno da flexibilização do nexo causal ${ }^{316}$.

\subsubsection{O dano}

\subsubsection{Responsabilidade civil sem dano?}

Desde sempre a responsabilidade civil foi entendida como o ramo da dogmática responsável por estruturar os pressupostos para a reparação de danos injustos, numa tentativa de fazer com que a situação jurídica da vítima retornasse ao statu quo ante.

No entanto, as recentes alterações de concepção da responsabilidade civil, mormente por parte da doutrina, têm repercutido também sobre o dano, que até há pouco parecia ser o único pressuposto inatacável da responsabilidade civil ${ }^{317}$.

\footnotetext{
${ }^{315}$ Principalmente, nas obras Verdade e Conjetura, Rio de Janeiro, Editora Nova Fronteira, 1983; O direito como experiência: introdução à epistemologia jurídica, $2^{\mathrm{a}}$ edição, $4^{\mathrm{a}}$ tiragem, São Paulo, Saraiva, 2010.

${ }^{316}$ Nesse sentido, Anderson Schreiber ensina que: "De certa forma, pode-se afirmar que as cortes têm se recusado a dar à prova do nexo causal o mesmo tratamento rigoroso e dogmático que, no passado, haviam atribuído à prova da culpa, com tão injustos resultados, preferindo navegar por opções teóricas mais ou menos amplas diante de uma legislação lacônica sobre a matéria”. Op. cit., p. 64.

${ }^{317}$ Ao seu tempo, José de Aguiar Dias, com base em Mazeaud et Mazeaud, afirmou que: "O dano é, dos elementos necessários à configuração da responsabilidade civil, o que suscita menos controvérsia. Com 
Vêm surgindo no Brasil, como já aventado, teses que procuram demonstrar que o futuro da responsabilidade civil estará antes na prevenção dos danos, do que em sua reparação.

Nas páginas que seguem, serão analisados os argumentos utilizados por alguns doutrinadores que, no direito brasileiro, sustentam esse entendimento.

\subsubsection{Argumentos em defesa da responsabilidade civil sem dano. Propostas para sua concretização no ordenamento jurídico brasileiro}

Para justificar a possibilidade de responsabilidade civil sem dano, Teresa Ancona Lopez parte da constatação de que existem na "sociedade de risco" "danos graves e irreversíveis", em relação aos quais a reparação não é possível. Dessa forma, apoiando-se nos ensinamentos de Catherine Thibierge, defende a necessidade de responsabilizar os agentes tão somente pelos riscos de danos graves e irreversíveis que criarem $^{318}$.

Segundo a autora, faz-se necessário separar o conceito de responsabilidade do conceito de indenização, de forma que a responsabilidade possa abarcar também a prevenção e a precaução de danos graves e irreversíveis. Isso é possível, afirma, "pois a idéia fundamentadora de todo o sistema de responsabilidade civil é a da proibição de causar dano a outrem (alterum non laedere)". E concluiu: "Hoje podemos afirmar que temos a responsabilidade civil reparatória e a responsabilidade civil preventiva" ${ }^{\text {319. }}$.

A autora salienta que "é possível caracterizar-se como dano (prejuízo) a ameaça ou risco de 'danos graves e irreversíveis"”, isto é, o chamado "dano de risco"320:

"Ainda nos socorrendo do direito à saúde, podemos lembrar de situações em que pessoas tiveram contato com algum vírus, mas

efeito, a unanimidade dos autores convém em que não pode haver responsabilidade sem a existência de um dano, e é verdadeiro truísmo sustentar esse princípio, porque, resultando a responsabilidade civil em obrigação de ressarcir, logicamente não pode concretizar-se onde nada há que reparar”. Da responsabilidade civil - Tomo II, $5^{\text {a }}$ ed. revista e aumentada, Rio de Janeiro, Forense, 1973, p. 339.

${ }_{318}^{318}$ LOPEZ, Teresa Ancona, op. cit., p. 133-139.

${ }^{319}$ LOPEZ, Teresa Ancona, ibid., p. 137-139.

${ }^{320}$ LOPEZ, Teresa Ancona, ibid. p. 139. 
não desenvolveram a doença ou porque ainda não passou o período da chamada 'janela imunológica', como no caso da AIDS (hoje essa hipótese é remota), e não é possível ainda averiguar se o exame vai dar positivo ou negativo; ou, então, porque há um lapso de tempo muito grande entre o contato e o desenvolvimento da doença, como no caso da temida 'hepatite C', que leva à cirrose hepática e à morte. Podemos imaginar a hipótese de determinada pessoa ter sido infectada, em transfusão de sangue, pelo vírus da hepatite $\mathrm{C}$, doença que, às vezes, demora 30 anos para se manifestar. Poderá pedir indenização pela ameaça de risco de desenvolver a doença? $O$ medo constante de ser portador de vírus de doença incurável é, com certeza, dano indenizável. Também poderíamos colocar a hipótese de uma ação civil pública contra o Município do Rio de Janeiro, em nome de toda a população carioca (não somente dos já contaminados), pelo risco de adquirir dengue por falta de precaução da Prefeitura do Rio de Janeiro. O dano aqui é o risco, $^{, 321}$.

Fixado esse entendimento, o grande desafio que se coloca, segundo Teresa Ancona Lopez, "é como exigir e, por conseqüência, sancionar os criadores de risco que não gerenciam adequadamente os perigos conhecidos (prevenção) e os riscos possíveis (precaução)" $^{322}$.

A autora relata que nas esferas penal e administrativa existe a fiscalização exercida por diversas autarquias (como Anvisa, Ibama, Cade) que "impedem, proíbem ou suspendem, por exemplo, a colocação de produtos ou remédios no mercado por suspeita de risco à saúde dos consumidores, a suspensão de publicidades que possam sugerir perigos, a proibição de cartéis que possam prejudicar economicamente os consumidores ou ainda a proibição do uso de bens imóveis que estejam ameaçando o equilíbrio ecológico e o futuro de um meio ambiente saudável para as futuras gerações"323. Contudo, afirma: "Haverá

\footnotetext{
${ }^{321}$ LOPEZ, Teresa Ancona, idem.

${ }^{322}$ LOPEZ, Teresa Ancona, ibid., p. 141.

${ }^{323}$ LOPEZ, Teresa Ancona, idem.
} 
hipóteses em que o poder de vigilância e fiscalização não existirá e somente medidas judiciais poderão atuar sancionando essa não-observância a atitudes preventivas ou antecipatórias como fundamentais para evitar danos graves e irreversíveis." A questão é, então, saber quais medidas judiciais poderão ser utilizadas ${ }^{324}$.

Em suas palavras:

"Mathilde Boutonnet, que estudou detalhadamente o assunto, sugere a criação de uma ação de responsabilidade civil preventiva.

$\mathrm{Na}$ verdade, as medidas acautelatórias, conservatórias e preventivas que já existem poderiam ser usadas nessas situações de forma emergencial para evitar danos graves, tanto individualmente, quanto através de ações coletivas. A Doutrina francesa tem mostrado a possibilidade de aplicação às ações preventivas, que têm por fundamento o princípio da precaução, dos procedimentos judiciais usados nos casos de conflitos de vizinhança, tendo em vista que a prevenção nesses casos é muito semelhante à usada no princípio da precaução. Haveria, portanto, o recurso à analogia para chegar-se ao julgamento. Visam as ações de vizinhança evitar danos temidos, como os desabamentos. Em todos os casos, há o risco conhecido. Para esse tipo de perigo, o direito dá àquele que teme, por exemplo, desmoronamentos o direito de propor a 'ação de dano infecto', que o Código Civil chama de ação de dano iminente. Temos essa possibilidade expressa no artigo 1.280, artigo $1.281 \mathrm{e}$ parágrafo único do artigo 1.305. Porém, e de forma pioneira, na França, mesmo diante da incerteza científica (risco hipotético), o Tribunal de Grasse (em 17/06/2003), confirmado pela Corte de Apelação de Aix em Provence (08/06/2004), decidiu, combinando a teoria da precaução com a teoria pelas perturbações à vizinhança, determinar a retirada de antena de

${ }^{324}$ LOPEZ, Teresa Ancona, ibid., p. 142. 
telefonia celular que emitia ondas eletromagnéticas supostamente perigosas à saúde da população vizinha. É o típico caso de risco incerto",325.

E concluiu:

"A tutela jurídica do princípio da precaução tem como instrumento de trabalho para o juiz o standard jurídico da precaução que está contido nesse princípio. Portanto, não haverá dificuldade de sua aplicação aos casos concretos, dada a flexibilização do standard que pede uma atitude prudente de comportamento diante de riscos conhecidos ou hipotéticos. Nicolas de Sadeleer acha que, sem dúvida, poderá o juiz com mais facilidade sancionar a falta a um dever de prudência invocando o princípio da precaução. Além disso, diz ele, em um contexto de incerteza onde as causalidades são múltiplas e complexas, as flexibilizações das exigências tradicionais de causalidade, tendo em vista o proveito das vítimas, podem também ser usadas a título de precaução"326.

Também Daniel de Andrade Levy defende a possibilidade de responsabilidade civil independentemente de dano ${ }^{327}$. Para tanto, o autor também vale-se dos princípios da prevenção e da precaução, construindo modelo de prevenção de danos estruturado a partir de duas funções: função preventiva como forma de evitar a repetição do dano e função preventiva como instrumento de antecipação do dano ${ }^{328}$.

A primeira consiste em, sumariamente, adotar políticas públicas ou decisões judiciais (por exemplo, "indenização punitiva”) que desestimulem novas práticas lesivas. O

\footnotetext{
${ }^{325}$ LOPEZ, Teresa Ancona, ibid., p. 142-143. Apesar de longa, a transcrição é necessária para a compreensão do pensamento da autora.

${ }^{326}$ LOPEZ, Teresa Ancona, ibid., p. 143.

${ }^{327}$ LEVY, Daniel de Andrade, op. cit., p. 146-147.

${ }^{328}$ LEVY, Daniel de Andrade, ibid., p. 135 e seguintes.
} 
autor, nesse sentido, cita decisão do Tribunal de Justiça do Rio de Janeiro que julgou o seguinte caso $^{329}$ :

\begin{abstract}
"Uma senhora carioca comprou a prazo uma bicicleta para o afilhado. Como não quitou a última parcela, o credor simplesmente retomou bruscamente a bicicleta da criança ao vêla na rua. Ajuizada a demanda indenizatória pela senhora em virtude da ofensa moral que o ato causara, o TJRJ decidiu condenar o credor a $\mathrm{R} \$ 1.000,00$ a título de danos morais, com caráter sancionatório 'para que não pratique mais ato lesivo à personalidade das pessoas,, 330 .
\end{abstract}

A segunda função da prevenção, isto é, a de antecipação do dano, busca tutelar duas situações: a do risco de danos graves e irreversíveis e a do risco como dano em $\mathrm{si}^{331}$.

O problema do risco de danos graves e irreversíveis, segundo o autor, refere-se principalmente aos danos ao meio ambiente e à saúde. Como problema relativo ao meio ambiente, o autor menciona o efeito estufa; relativamente à saúde, a contaminação pelo HIV. Para Daniel de Andrade Levy, a função preventiva da responsabilidade civil, nesses casos, deverá regular toda conduta que possa resultar "em dano grave o suficiente para colocar em risco o que há de mais vital para a sobrevivência da espécie”, por meio de medidas de suspensão ou inibição das atividades supostamente nocivas ${ }^{332}$.

Quanto à questão do risco como dano em si, a função preventiva, nesse caso, "consiste em responsabilizar uma conduta considerando que o simples risco que cria para as vítimas já é, em si, um ato lesivo",333. O autor vale-se de dois julgados para explicar a concretização desse alargamento da noção de dano, um da Corte de Apelação de Lyon e outro do Tribunal de Justiça de São Paulo. Segundo o autor, a decisão da Corte francesa “considerou possível a reparação de dano moral resultante da angústia que afetou pacientes

\footnotetext{
${ }^{329}$ LEVY, Daniel de Andrade, ibid., p. 135-141.

${ }^{330}$ LEVY, Daniel de Andrade, ibid., p. 139.

${ }^{331}$ LEVY, Daniel de Andrade, ibid., p. 141.

${ }^{332}$ LEVY, Daniel de Andrade, ibid., p. 141-146.

${ }^{333}$ LEVY, Daniel de Andrade, ibid., p. 146-147.
} 
portadores de sondas cardíacas defeituosas, mesmo sem que qualquer dano delas oriunda houvesse sido comprovado",334.

Já o julgado do Tribunal de Justiça de São Paulo reformou decisão de primeira instância que havia decidido que a mera presença do componente hexaclorobenzeno, utilizado na produção de pesticida, no sangue de indivíduos não era suficiente para caracterizar dano material e moral, pois não havia nenhuma prova de que as vítimas desenvolveriam câncer no futuro. O Tribunal, no entanto, entendeu que "a angústia em saber-se contaminado por substância que poderá causar qualquer doença" por si só caracteriza dano moral. Tendo por base esta decisão do Tribunal, o autor sugere, então, ir além: “A própria contaminação, sob essa perspectiva da Responsabilidade Civil, já seria o fracasso da disciplina. É possível, então, admitir uma ação indenizatória ainda que a contaminação das vítimas não tivesse ocorrido, diante do mero risco grave, sério e comprovado disso vir a ocorrer" ${ }^{, 335}$.

Ainda para elucidar a aplicação desse viés da função preventiva, o autor cria duas situações hipotéticas. Transcreve-se:

“(...) imagine-se o exemplo de uma usina que tem despejado os seus detritos, sem tratamento, em um rio. Caso um morador ribeirinho tenha tido as suas terras de plantio contaminadas, com a consequente perda da safra, poderá ingressar com uma ação indenizatória para que a usina repare os seus danos materiais e, quiça, até mesmo morais. Este é o caminho tradicional. Aqui, o julgador, em uma visão que reflete os debates atuais, poderia, além de reparar integralmente o prejuízo do autor, definir também uma indenização punitiva, caso entenda que a simples reparação não será suficiente para que a usina tome as medidas necessárias para evitar o dano no futuro, inclusive com base na relação custo/benefício entre a implantação de uma estação de tratamento e a sua receita",336.

\footnotetext{
${ }^{334}$ LEVY, Daniel de Andrade, ibid., p. 149.

${ }^{335}$ LEVY, Daniel de Andrade, ibid., p. 150.

${ }^{336}$ LEVY, Daniel de Andrade, ibid., p. 164.
} 
E o autor prossegue com a descrição de uma segunda hipótese:

"Mas agora imaginemos que a contaminação do rio sequer aconteceu, mas há risco comprovado de que a usina passará a despejar seus detritos naquele curso d'água. Aqui, a Responsabilidade Civil Preventiva imporia uma ação a ser proposta pela vítima potencial, pelo Ministério Público, por associação ou pela Defensoria Pública, a fim de evitar a concretização do dano. Nesse caso, o magistrado pode, além de determinar a imediata eliminação do risco, impor indenização que estimulasse o agente a tomar as medidas de prevenção necessárias para evitar, ao máximo, a futura ocorrência do dano",337. (sem grifos no original).

Por fim, o autor sugere uma reestruturação da responsabilidade civil em duas diferentes direções:

"uma que busca regular condutas e outra que procura reparar eficientemente. É esse duplo caminhar que demonstra a insuficiência de um eixo único, impondo-se uma nova sistematização da disciplina: de um lado uma Responsabilidade Civil que enxerga o agente, fundada em sua conduta, e que chamaremos de 'Direito das Condutas Lesivas"; de outro, uma disciplina que se preocupa apenas em indenizar a vítima, fundada nos novos mecanismos indenizatórios, e que denominaremos 'Direito de Danos", 338 .

Ainda na defesa da responsabilidade civil sem dano, Lucas de Abreu Barroso e Pablo Malheiros da Cunha Frota procuram estabelecer o conteúdo do chamado "direito de danos" para com isso diferenciá-lo da responsabilidade civil clássica. Para eles, a responsabilidade civil clássica funciona como "moralização jurídica da autonomia privada", tendo foco no ofensor e na ética da liberdade, enquanto que o direito de danos

\footnotetext{
${ }^{337}$ LEVY, Daniel de Andrade, idem.

${ }^{338}$ LEVY, Daniel de Andrade, ibid., p. 5 e 217 e seguintes.
} 
tem foco na vítima - com prevalência da máxima "in dubio pro vitima" - e na ética da alteridade $^{339}$.

Os atores elencam os seguintes objetivos do direito de danos:

“a) ampliar o número de vítimas tuteladas, de danos reparáveis e de forma de reparação, por meio da flexibilização dos meios de prova, da diluição da antijuridicidade, da desnaturalização da culpa e da relativização do nexo causal;

b) intensificar a responsabilização, concedendo-se reparações pecuniárias, proporcionais ao caso concreto, e também despatrimonializadas, como a retratação pública e as tutelas específicas de dar, fazer e não fazer, ou mesmo in natura (Código de Processo Civil, arts. 461 e 461-A e Código Civil, arts. 233, 247 e 250);

c) fomentar os princípios da precaução e da prevenção diante da crescente socialização dos riscos e do incremento das situações de dano, que ensejam uma noção de responsabilidade plural, solidária e difusa - haja vista à (re)personalização do direito civil;

d) concretizar a responsabilidade sem danos, pois a possibilidade de sua verificação em potencial já acionaria o dever de reparar por parte daquele que possa vir a causá-lo;

e) densificar de maneira real e concreta os direitos e as garantias fundamentais da pessoa humana no tange aos riscos de danos a que está submetida em razão da evolução tecnológica dos bens e dos serviços postos para consumo, principalmente os relacionados à saúde e ao meio ambiente;

f) garantir ampla e integral reparação às vítimas, com extensão de igual direitos a todos quantos alcançados indiretamente pelo dano ou expostos ao risco que o provocou, mesmo que por circunstâncias fáticas, devendo nessa hipótese o valor da

${ }^{339}$ BARROSO, Lucas Abreu; FROTA, Pablo Malheiros da Cunha, op. cit., p. 104-105. 
reparação ser destinado a um fundo voltado para o estudo e a pesquisa da antecipação e do equacionamento dos danos oriundos de determinadas atividades socioeconômicas;

(sic) (h) tornar irrelevante a concausa, 'com el alcance de asignar la totalidad del daño a quien solo aporto una de las causas concurrentes' [citação de Felix Represas e Marcelo J. Lopez Mesa], objetivando diluir as responsabilidades individuais pelo dano;

i) aumentar as espécies de instrumentos reparatórios, coordenando-os com os já existentes, tais como: fundos públicos substitutivos da responsabilidade civil para os casos mais comuns de danos; pagamento antecipado de tarifas pelo Estado às vítimas, a economizar custos, a reduzir o montante dos danos, o tempo de espera da vítima no recebimento do montante reparatório e os gastos judiciais; promoção de demandas diretas da vítima contra o segurador do responsável pelo dano; pactuação obrigatória de seguro para atividades com alta sinistralidade (p. ex., seguro ambiental) etc. ${ }^{, 340}$.

Defendem ser preciso, com urgência, "transitar para o direito de danos, que melhor ampara as vítimas, porque o tradicional instituto da responsabilidade civil, apoiado nos critérios subjetivo e objetivo de valoração da responsabilidade, acabou por contribuir para uma contínua não reparação das vítimas dos múltiplos danos sofridos pela pessoa humana no contexto da sociedade contemporânea"341.

Advertem que:

"A maior parte da doutrina, da jurisprudência e da legislação pátrias, no entanto, ainda não compreendeu a alteração do paradigma da responsabilidade civil para o do direito de danos. Saliente-se que não existe qualquer razão para o direito brasileiro não ultrapassar esta fronteira epistemológica, como

\footnotetext{
${ }^{340}$ BARROSO, Lucas Abreu; FROTA, Pablo Malheiros da Cunha, ibid., p. 105-106.

${ }^{341}$ BARROSO, Lucas Abreu; FROTA, Pablo Malheiros da Cunha, ibid., p. 114.
} 
ocorreu em diversos países com realidades sociais bastante parecidas com a nossa"342.

Para elucidar a necessidade de "alteração do paradigma da responsabilidade civil para o direito de danos" ${ }^{\text {343 }}$, os autores valem-se do caso da talidomida, medicamento criado na Alemanha e comercializado por diversos laboratórios, a partir de 1957, para controlar ansiedade, tensão e náuseas. Na época em que foi introduzida no mercado, os laboratórios diziam que a substância não era tóxica, sendo vendida, inclusive, sem prescrição médica. O uso por gestantes, contudo, acabou gerando uma deficiência física nas crianças que ficou conhecida como síndrome da focomelia ou da talidomida ${ }^{344}$.

Os autores informam que o governo brasileiro retirou o medicamento do mercado em 1965. Em seguida, foram editadas diversas portarias para regulamentar o registro, a produção, a fabricação, a comercialização, a prescrição e o descarte dos produtos à base de talidomida. Apesar disso, nas décadas de 1990 e 2000, a talidomida passou a ser utilizada no tratamento de diversas doenças (como leucemia, hanseníase, lúpus etc.), fazendo com que surgissem novas vítimas da síndrome da talidomida, sobretudo, "por causa da desinformação da população, dos profissionais da área da saúde e pela automedicação dos usuários, prática infelizmente comum no Brasil”345.

Para tutelar os danos causados às vítimas da talidomida, o governo brasileiro editou em 1982 a Lei 7.070, concedendo a elas pensão especial, vitalícia e mensal, sendo que, mais recentemente, a Lei 12.190, de 13 de janeiro de 2010, passou a prever a concessão de indenização por dano moral - no valor de $\mathrm{R} \$$ 50.000,00 (cinquenta mil reais), multiplicado pelo número dos pontos indicadores da natureza e do grau da dependência resultante da deformidade física (conforme artigo $1^{\circ}, \S 1^{\circ}$, da Lei 7.070/1982) - a essas vítimas, a ser paga pela União ${ }^{346}$.

\footnotetext{
${ }^{342}$ BARROSO, Lucas Abreu; FROTA, Pablo Malheiros da Cunha, ibid., p. 107.

${ }^{343}$ BARROSO, Lucas Abreu; FROTA, Pablo Malheiros da Cunha, idem.

${ }^{344}$ BARROSO, Lucas Abreu; FROTA, Pablo Malheiros da Cunha, ibid., p. 100.

${ }^{345}$ BARROSO, Lucas Abreu; FROTA, Pablo Malheiros da Cunha, ibid., p. 100-101.

${ }^{346}$ BARROSO, Lucas Abreu; FROTA, Pablo Malheiros da Cunha, ibid., p. 101-102; 110.

Vide o texto da lei: “Art. $1^{\circ}$ É concedida indenização por dano moral às pessoas com deficiência física decorrente do uso da talidomida, que consistirá no pagamento de valor único igual a $\mathrm{R} \$ 50.000,00$ (cinquenta mil reais), multiplicado pelo número dos pontos indicadores da natureza e do grau da dependência resultante da deformidade física ( $\$ 1^{\circ}$ do art. $1^{\circ}$ da Lei $\mathrm{n}^{\mathrm{o}} 7.070$, de 20 de dezembro de 1982).
} 
Sobre esse problema da talidomida no Brasil, os autores entendem que, diante dos riscos dos efeitos da talidomida e com base nos princípios da prevenção e da precaução, o Brasil poderia ter impedido a sua comercialização, assim como o fizeram os Estados Unidos ${ }^{347}$.

Afirmam que, apesar de a Lei 12.190/2010 fazer com que o Estado assuma para si "a total responsabilidade pelos danos decorrentes do uso da talidomida", a hipótese é de responsabilidade solidária do Estado e dos laboratórios pela reparação dos danos causados às vítimas diretas ou indiretas da síndrome da talidomida, porque ambos concorreram para o "risco de dano" ao permitir que o medicamento fosse utilizado sem que houvesse as devidas pesquisas e informações sobre seus efeitos ${ }^{348}$. Nesse sentido, entendem que o direito brasileiro ainda admite a exclusão da responsabilidade civil do agente pelo risco do desenvolvimento do bem e/ou serviço quando, ao tempo de sua pesquisa e colocação no mercado, não era possível avaliar os efeitos nocivos do bem ou serviço. Contudo, afirmam que esta causa de exclusão da responsabilidade civil mostra-se incompatível com o direito de danos, o qual transfere os prejuízos àqueles que autorizaram à coloção do produto no mercado e àqueles que colocaram o produto no mercado ${ }^{349}$.

Sustentam ainda o cabimento de reparação "aos consumidores pelo risco potencial que lhes foi causado pela exposição ao medicamento, hipótese em que a prestação reparatória seria revertida para fundos de pesquisa e tratamento da Síndrome da Talidomida e outras afetações à saúde pública"350.

Art. $2^{\underline{0}}$ Sobre a indenização prevista no art. $1^{\underline{0}}$ não incidirá o imposto sobre renda e proventos de qualquer natureza.

Art. $3^{\circ} \mathrm{O}$ art. $3^{\circ}$ da Lei $\mathrm{n}^{\mathrm{o}} 7.070$, de 1982 , passa a vigorar com a seguinte redação:

'Art. $3^{\circ}$. A pensão especial de que trata esta Lei, ressalvado o direito de opção, não é acumulável com rendimento ou indenização que, a qualquer título, venha a ser pago pela União a seus beneficiários, salvo a indenização por dano moral concedida por lei específica. ' (NR)

Art. $4^{\circ}$ As despesas decorrentes do disposto nesta Lei correrão à conta de dotações próprias do orçamento da União.

Art. 5ำ A indenização por danos morais de que trata esta Lei, ressalvado o direito de opção, não é acumulável com qualquer outra da mesma natureza concedida por decisão judicial.

Art. $6^{\circ}$ Esta Lei entra em vigor na data de sua publicação, produzindo os efeitos financeiros a partir de $1^{\circ}$ de janeiro de 2010".

${ }^{347}$ BARROSO, Lucas Abreu; FROTA, Pablo Malheiros da Cunha, ibid., p. 110-111.

${ }^{348}$ BARROSO, Lucas Abreu; FROTA, Pablo Malheiros da Cunha, ibid., p. 111.

${ }^{349}$ BARROSO, Lucas Abreu; FROTA, Pablo Malheiros da Cunha, ibid., p. 113.

${ }^{350}$ BARROSO, Lucas Abreu; FROTA, Pablo Malheiros da Cunha, ibid., p. 111. 
Nessa mesma linha argumentativa de Lucas Abreu Barroso e Pablo Malheiros da Cunha Frota, Luiz Edson Fachin também admite responsabilidade civil sem dano. Em suas palavras:

\begin{abstract}
"Impende, ainda, altear a passagem da responsabilidade civil ao direito de danos, mais focado na vítima e menos no causador ou na reprovação de sua conduta. $\mathrm{O}$ dano ao projeto de vida é outro exemplo de compensação relevante que a racionalidade jurídica vai abrigando. A própria ideia decorrente do princípio da precaução, que pode conduzir à indenizabilidade da ameaça de dano, representa um interesse, ainda que paradoxal, passo à frente ao expor a responsabilidade sem dano" 351 .
\end{abstract}

Da análise dessas correntes de pensamento, que se entende serem suficientes para a compreensão dos contornos do que se pretende com um "direito de danos", podem extrair-se algumas conclusões:

(i) todas elas valem-se dos princípios da precaução e da prevenção para defender a possibilidade de responsabilização civil sem dano;

(ii) nesse sentido, fala-se em responsabilidade civil preventiva, como outra função a ser desempenhada pela responsabilidade civil, ao lado da função reparadora;

(iii) a responsabilidade civil preventiva consistiria tanto na adoção de políticas públicas quanto de instrumentos jurídicos hábeis a evitar o dano, dentre os quais se admite a fixação de "indenização" mesmo sem haver dano, bem como a fixação de "indenização punitiva" esta para evitar a ocorrência de outros danos no futuro.

(iv) quando se fala em fixação de "indenização" sem dano ora quer-se referir a situações em que, de fato, não há dano, ora quer-se referir a situações em que há dano - em geral, cita-se, nos exemplos reproduzidos acima, o dano extrapatrimonial que atinge a integridade psíquica das vítimas, consistente na angústia, no medo, no pânico de

\footnotetext{
${ }^{351}$ Responsabilidade civil contemporânea no Brasil: notas para uma aproximação, in Revista Jurídica, n. 397, novembro/2010, p. 17-18.
} 
ser contaminado por um vírus ou por uma substância radioativa, de ter seu imóvel depredado pelo rompimento de um reservatório etc.

Postas essas principais conclusões, cumpre analisá-las à luz do direito positivo brasileiro.

\subsubsection{Desnecessidade de substituição da estrutura atual de responsabilidade civil por um "direito de danos"}

O enfrentamento científico da questão da necessidade ou não de adoção no Brasil do modelo do "direito de danos" exige a superação sucessiva de três questões: (i) existe um modelo de direito de danos?; (ii) os "danos potenciais", principal razão da busca por um novo modelo, são um problema solucionável? (iii) o sistema jurídico brasileiro atual não contém mecanismos aptos a evitar, desestimular e sancionar a prática de condutas potencialmente lesivas?

Com relação à primeira dessas questões, até onde se tem notícia e ao menos no Brasil, não há nenhum trabalho dogmático que apresentou consistentemente um modelo que, ao menos em tese, fosse apto a substituir o atual esquema de responsabilidade civil ${ }^{352}$ seguindo a ideia de negação dialética de Goffredo Telles Junior, pela qual se abandona o que não funciona mais, porém, conserva-se o útil ${ }^{353}$. Em verdade, o que há, como se viu, são trabalhos que se dedicaram a defender a necessidade de substituição do atual modelo de responsabilização civil, mas nenhum que tenha, de fato, proposto um modelo novo capaz de conservar os mecanismos eficientes do modelo a ser substituído, ao mesmo tempo em que apresenta novos mecanismos suficientemente eficientes para solucionar os problemas que, por não serem solucionáveis pelo paradigma antigo, ensejaram sua superação $^{354}$.

\footnotetext{
${ }^{352}$ Há inúmeras obras de responsabilidade civil, razão pela qual não é possível afirmar que não há, ainda, um modelo dogmático de direito dos danos.

${ }^{353}$ Direito Quântico: ensaio sobre o fundamento da ordem jurídica, $8^{\mathrm{a}}$ ed. revista, São Paulo, Editora Juarez de Oliveira, 2006.

${ }^{354}$ Como ensina Karl R. Popper, “o progresso em ciência, embora sendo revolucionário, e não meramente cumulativo, é, em certo sentido, sempre conservador: uma teoria nova, por muito revolucionária que seja, deve ser sempre capaz de explicar na íntegra o êxito da teoria que a antecedeu. Em todos os casos em que esta teve êxito, deve reproduzir resultados ao menos tão bons como os seus e, se possível, melhores. Assim, a teoria precedente deve, nestes casos, constituir uma boa aproximação à teoria nova, embora tenha de haver
} 
Já quanto à segunda questão, isto é, sobre os danos potenciais serem ou não um problema solucionável, antes de procurar-se respondê-la, faz-se necessária uma correção terminológica. A expressão "danos potenciais" é infeliz porque se refere a algo que, do ponto de vista fenomênico, não existe ainda. Por essa razão, é mais preciso referirse a condutas potencialmente lesivas, uma vez que se pode analisar se a conduta praticada (existente como ato, e não mera potência de ato) tem em si o gérmen da lesividade.

Feita essa nota terminológica, pode-se prosseguir no enfrentamento da questão (sobre se as condutas potencialmente lesivas são ou não um problema solucionável) com a afirmação de um truísmo: toda conduta é, em tese, potencialmente lesiva. Diante desta irrefutável constatação, resta apenas a possibilidade de classificar as condutas potencialmente lesivas em lícitas ou ilícitas conforme, respectivamente, a tolerabilidade ou intolerabilidade dos riscos correlatos.

Esse quantum de tolerabilidade de geração de riscos, contudo, não é fixável de modo apriorístico, ao contrário, via de regra, só será determinado diante das especificidades da situação concreta. Sem dúvida, então, que a ideia de tolerabilidade ou intolerabilidade dos riscos exige que se confie em alguém para, no caso concreto, decidir sobre a licitude ou ilicitude daquela conduta, seja este alguém o juiz ou outro órgão, como as agências reguladoras, por exemplo, a Anvisa.

Mas, afirmar que se podem classificar as condutas potencialmente lesivas em lícitas ou ilícitas, não responde à questão proposta: a de saber se o problema da existência de risco criado por certas condutas é ou não solucionável.

Se se entender que o problema é o risco em si, isto é, o medo, a angústia, a sensação de insegurança que a conduta potencialmente lesiva traz consigo, a resposta só pode ser negativa. Isso porque qualquer sociedade, por mais rudimentar que seja, só evolui por meio do risco e, mais do que isso, pela causação e sofrimento de danos.

preferencialmente outros casos em que a teoria nova faculte resultados diferentes e melhores que os da antiga". O mito do contexto: em defesa da ciência e da racionalidade, tradução de Paula Taipas, Coleção Biblioteca de Filosofia Contemporânea, Lisboa, Edições 70, 2009, p. 42. 
A noção própria de evolução é intrinsecamente ligada ao erro, ao insucesso, em suma, ao dano. Como elucida Karl Popper, a evolução de maneira geral ocorre a partir do sistema de tentativa e erro, em que cada sucesso é fruto de inúmeros insucessos anteriores. São suas palavras:

"As ciências naturais, bem como as ciências sociais, começam sempre por problemas, pelo fato de algo nos causar espanto, como os filósofos gregos costumavam dizer. Para resolver estes problemas, as ciências usam fundamentalmente o mesmo método que o senso comum emprega, o método da tentativa $e$ erro. Para ser mais preciso, trata-se do método que consiste em experimentar soluções para o nosso problema e depois pôr de parte as falsas considerando-as errôneas. Este método pressupõe que trabalhemos com um grande número de soluções experimentais. É testada e eliminada uma solução após a outra. No fundo, este procedimento parece ser o único que é lógico"355.

Nesse sentido, então, é impossível evitar condutas potencialmente lesivas, pois isso equivaleria ao estancamento absoluto da evolução, algo que a natureza humana seria incapaz de suportar.

Mas, afirmar a inevitabilidade de condutas potencialmente lesivas, não é o mesmo de adotar uma postura conformista, ao contrário, esta constatação deve, antes, ensejar a reflexão sobre que postura adotar diante desta situação e quais as soluções que, eventualmente, tem-se à disposição.

É, pois, momento de verificar se o sistema jurídico atual contém mecanismos de tutela contra condutas potencialmente lesivas que possam ser tidas por ilícitas ou se, ao contrário, é necessário um novo modelo dogmático para tanto. Como os defensores da superação da estrutura de responsabilização civil afirmam que o direito positivo brasileiro é insuficiente para atender às novas demandas sociais, essa verificação

\footnotetext{
${ }^{355}$ POPPER, Karl R., A lógica e a evolução da teoria científica, in A vida é aprendizagem. Epistemologia evolutiva e sociedade aberta, tradução de Paula Taipas, Coleção Biblioteca de Filosofia Contemporânea, Lisboa, Edições 70, 1999, p. 17.
} 
será realizada pondo-se entre parênteses os papéis da doutrina e da jurisprudência, isto é, considerará apenas as normas do direito positivo brasileiro.

Analisando-se o sistema normativo brasileiro, mormente as disposições processuais, conclui-se que houve sensível alteração de paradigma na medida em que a "solução normativa" passou a ser prioritariamente a concessão ao autor da preservação ou restauração de sua situação jurídica em detrimento de sua mera sub-rogação em perdas e $\operatorname{danos}^{356}$.

O conjunto de normas processuais, a partir, principalmente, do artigo 461, caput e $\S \S 1^{\circ}$ a $6^{\circ}$ do Código de Processo Civil, confere instrumentos suficientes não só para impedir que sejam adotadas condutas potencialmente lesivas ilícitas, como também para fazê-las cessar caso tenham lugar.

Ademais, em harmonia com a tendência de efetividade das tutelas jurisdicionais, o direito positivo brasileiro conta com um conjunto de normas sobre processo civil coletivo apto a atender aos interesses individuais homogêneos, coletivos e difusos, bastando que com lucidez se o interprete.

Ricardo de Barros Leonel, em obra sobre o processo coletivo em que realizou coerente e precisa sistematização das normas processuais brasileiras acerca do tema, trouxe conclusão que merece integral citação:

"As diversas leis voltadas à defesa dos interesses supraindividuais em juízo formam um sistema integrado, o denominado processo coletivo. Não se pretende afirmar seja ele um novo processo civil, com o abandono de todo o proveito científico e legislativo obtido ao longo dos tempos. (...). Adotando como critérios diferenciais o grau de importância da norma, sua abrangência e a completude da regulamentação nela contida, verifica-se a existência de um sistema integrado

\footnotetext{
356 Também neste sentido, Cândido Rangel Dinamarco ensina que "como instrumento do direito material, o processo deve dar a quem tem razão precisamente aquilo que segundo este ele tem o direito de obter (bens da vida, materiais ou imateriais)". Instituições de direito processual civil, v. I, $6^{\circ}$ ed., São Paulo, Malheiros, 2009, p. 151.
} 
destinado à tutela dos interesses coletivos, difusos e individuais homogêneos. No centro deste sistema, como vetores de princípios básicos, encontram-se o Código do Consumidor e a Lei da Ação Civil Pública, que se complementam e interagem recíproca e integralmente" ${ }^{, 357}$.

O autor tem razão. Com boa vontade interpretativa e sem a ânsia de inovar por inovar, é possível perceber que o sistema normativo brasileiro é capaz de atender à demanda social por segurança sem que seja necessária, ao menos por enquanto, nenhuma "revolução" dogmática.

Superada esta questão, pode-se investigar se a satisfação da demanda social por segurança é tema que pertence propriamente à responsabilidade civil em sentido estrito.

Tudo indica que a insistência em enquadrar a prevenção e a precaução no ambiente normativo e dogmático da responsabilidade civil seja fruto do vício lógico consistente em tratar como idênticos objetos apenas semelhantes.

A responsabilidade civil e as ideias de prevenção/precaução estão funcionalizadas a servirem ao princípio do neminem laedere, porém cada uma ao seu

\footnotetext{
${ }^{357}$ Manual do Processo Coletivo, São Paulo, Revista dos Tribunais, 2002, p.147 e 148. Ao final de seu trabalho, o autor apresenta, entre outras, a seguinte conclusão: "No exame da legislação em vigor, nota-se que qualquer situação que tenha conotação metaindividual, onde se identifique interesses difusos, coletivos ou individuais homogêneos, encontra via de implementação em juízo. Há proteção jurisdicional de interesses individuais homogêneos não só no âmbito do Código do Consumidor, mas com relação a qualquer matéria, como nas questões ambientais, tributárias etc.”. Ibid., p. 432.

Esta constatação sobre a aparelhamento do direito brasileiro no que tange à tutela dos direitos coletivos é muito importante, porque, frequentemente, transportam-se críticas feitas aos direitos estrangeiros para o direito pátrio, mas que a ele não se aplicam. Geneviève Viney, em artigo já citado acima, que foi publicado em 2008, ao discorrer sobre a necessidade de criação de um procedimento específico para a indenização dos danos de massa, dirige sua advertência aos países europeus: "Aliás, depois dos Estados Unidos, que há muito tempo conhecem as class actions, geralmente utilizadas em casos envolvendo responsabilidade pelo fato do produto defeituoso, os legisladores do Quebec e de Ontário criaram igualmente um recurso coletivo que desde então tem tido boa penetração nas lides judiciárias, e alguns outros países, entre os quais o Brasil, seguiram a mesma via. A introdução de tal recurso coletivo ou 'ação grupal' é hoje reclamada com insistência em diversos países europeus que no momento o ignoram, entre os quais a França, mas ela vai de encontro no momento com a hostilidade resoluta de profissionais que receiam que ela encoraje ações por responsabilidade dirigidas contra empresas, principalmente em casos de danos seriais de consumo. É por isso que, malgrado uma demanda formulada explicitamente pelo presidente da República Francesa no início de 2005, a criação desta ação é incessantemente retardada e nenhum projeto de lei foi adotado nesse sentido até o momento". Op. cit., p. 53.
} 
modo. Os papéis sociais dos institutos jurídicos da prevenção/precaução e da responsabilidade civil são interdependentes, mas distintos. Há entre eles relação lógica de subsidiariedade, sendo a responsabilidade civil fragmentária à prevenção/precaução.

O esquema jurídico de responsabilização civil somente será deflagrado se não houver ou se falhar o esquema jurídico antecedente de prevenção/precaução, daí seu caráter inegavelmente fragmentário.

Porém, diferentemente da responsabilidade civil, que é instituto pertencente exclusivamente ao Direito, os institutos da prevenção/precaução são multidisciplinares e operam em vários níveis sociais. Pode-se dizer que o Poder Legislativo deve legislar se pautando nos institutos da prevenção/precaução, por exemplo, autorizando o Executivo a conceder isenções tributárias aos agentes econômicos que adotarem tais ou quais agendas ecológicas ou consumeristas, bem como criando mecanismos administrativos de sanções a comportamentos que infrinjam a pauta previamente estipulada de observância da prevenção/precaução. Com relação ao Poder Judiciário, é coerente sustentar que ele deve levar em consideração os institutos da prevenção/precaução no momento de avaliar a incidência normativa sobre certa situação fática, como no caso do parágrafo único do artigo 927 do Código Civil, a fim de decidir que quem não adota certas medidas de prevenção/precaução aumenta o risco inerente à sua atividade e, portanto, deve responder objetivamente pelos riscos que causa.

No entanto, é insustentável afirmar que, por ocasião da deflagração da estrutura de responsabilização civil, o Poder Judiciário possa (i) punir o causador do dano, ou (ii) determinar que o agente "indenize" na ausência de dano.

Esses modos de desvirtuar a responsabilização civil são incoerentes e irresponsáveis. Incoerentes porque ignoram complemente as mais elementares noções de sistema jurídico; irresponsáveis, porque o fazem ao arrepio de princípios basilares de qualquer sistema jurídico civilizado.

De forma a demonstrar com clareza o porquê de adjetivar-se como incoerentes e irresponsáveis estas formas de desvirtuamento da responsabilidade civil, 
analisar-se-ão sucinta e separadamente as tendências de (i) punir o causador do dano e (ii) determinar que o agente "indenize" na ausência de dano.

\subsection{Responsabilidade civil e punição do causador do dano}

Contemporaneamente, conforme assinalado, sustenta-se que a responsabilidade civil teve ou deve ter sua finalidade ampliada por meio dos punitive damages ou exemplary damages, que serviriam para punir o causador do dano e também para desestimular o lesante ou outros membros da coletividade a praticar conduta causadora de dano injusto.

Para melhor compreender a questão das "funções" da responsabilidade civil, convém atentar para a distinção entre função (alvo) e efeitos secundários (colaterais) consequências - da realização da função.

A responsabilidade civil, como de resto todo mecanismo jurídico de imposição de sanção, possui, em maior ou menor grau ${ }^{358}$, como efeitos a prevenção especial (dissuasão do autor da conduta para que não a repita) e a prevenção geral (dissuasão dos membros da comunidade para que não adotem a conduta adotada pelo sancionado), não havendo nisso nenhuma novidade.

Assim, quando a alguém é imposto o dever de reparar o dano injusto que causou, a indenização da vítima (finalidade da responsabilização civil) poderá também funcionar como medida para que o sancionado não mais adote aquele comportamento potencialmente lesivo (prevenção especial) e, ainda, para desestimular outras pessoas a imitarem a conduta lesiva do sancionado (prevenção geral).

Não obstante, os defensores da ampliação da finalidade da responsabilidade civil não se contentam em dar ênfase às funções colaterais e pretendem alterar radicalmente a própria estrutura da responsabilidade civil por meio do aumento do valor imposto como "indenização". Tal valor, agora superior ao que seria suficiente a reparar a

\footnotetext{
${ }^{358}$ As sanções criminais, em geral, têm maior força dissuasória pelo fato de atingirem, no geral, não - ou não só - o patrimônio, mas a liberdade de locomoção dos indivíduos.
} 
vítima, há de ser tal que transforme os efeitos colaterais em efeitos principais, que ladeariam a função reparatória.

A ideia não é ruim. Na se pode duvidar de que o sistema jurídico esteja autorizado a punir aquele que cause danos injustos, mas esta punição não é papel da responsabilidade civil e não pode ser feita através da indenização, bastando a esta conclusão simples leitura do artigo 944 do Código Civil.

Lembre-se, inicialmente, de que o sistema jurídico brasileiro é pertencente à família do civil law e tem como "inegável ponto de partida"359 o direito positivo, mais especificamente as normas que o compõem. Então, já se pode afirmar a incoerência e a irresponsabilidade da tentativa de atribuir viés punitivo à responsabilidade civil brasileira a partir da leitura do artigo $5^{\circ}$, inciso XXXIX, $2^{a}$ parte, da Constituição Federal de $1988^{360}$.

O artigo $5^{\circ}$, inciso XXXIX da Constituição Federal contém duas normas: uma que trata da definição de crime, a qual não tem interesse nessa análise, e outra que trata da cominação de pena, seja por que motivo for. Esta segunda norma do dispositivo autoriza concluir que as sanções punitivas, tenham elas natureza criminal, administrativa ou civil, por serem consequências de uma norma de proibição, devem ser submetidas ao princípio da legalidade, "garantia essencial dos direitos individuais contra a arbitrariedade dos órgãos incumbidos da aplicação da lei”,361.

Portanto, o princípio da legalidade afasta a possibilidade de defender-se que o Judiciário possa, legitimamente, ampliar o quantum da indenização para punir o causador do dano, afinal, não há nenhuma cominação legal que o autorize a isso.

Além dessa inequívoca proibição constitucional, a tentativa de embutir função punitiva na responsabilidade civil é retrocesso histórico evidente.

\footnotetext{
${ }^{359}$ Alusão ao princípio da inegabilidade dos pontos de partida. Cf.: Tércio Sampaio Ferraz Jr.. Cf.: Introdução ao estudo do direito: técnica, decisão e dominação, $4^{\mathrm{a}}$ ed., São Paulo, Atlas, 2003.

360 “Art. $5^{\circ}$. (...).

XXXIX - não há crime sem lei anterior que o defina, nem pena sem prévia cominação legal;"

${ }^{361}$ BOITEUX, Elza Antonia Pereira Cunha, A função ética da pena privada, tese apresentada à Faculdade de Direito da Universidade de São Paulo para inscrição em concurso público visando à obtenção de título de livre docente, São Paulo, 2010, p. 77.
} 
Conforme se demonstrou no capítulo 2 dessa dissertação, as responsabilizações civil e penal distinguiram-se a partir da primeira codificação, isto é, com a edição do Código Civil francês em 1804 e do Código Civil alemão (BGB) em 1900. Essa distinção em responsabilização civil e penal foi fundamental para a evolução da responsabilidade civil, podendo-se mesmo afirmar que sem ela, até hoje, não haveria espaço para responsabilidade civil objetiva.

Como abordado, a ideia de responsabilização em geral tem por objeto situações socialmente inconvenientes que, em um primeiro momento histórico, eram aquelas provocadas por condutas reprováveis. O alvo, então, do esquema de responsabilização - sem qualquer distinção em civil e penal - eram as condutas socialmente reprováveis.

Se o foco da responsabilização eram as condutas reprováveis, mister que tais condutas apresentassem alguma nota que permitisse sua qualificação como inconvenientes. Tal nota foi justamente o modo com que a conduta foi realizada. Eram qualificadas como socialmente inconvenientes as condutas dirigidas conscientemente a causação de um mal (dolosas) e as condutas desastradas (culposas). Tanto as responsabilizações penais quanto as civis só se faziam sentir quando esse pressuposto estivesse preenchido, o que as qualificava como eminentemente subjetivas.

Se a premissa era evitar condutas causadoras de situações sociais indesejadas, naturalmente que só se poderia sancionar o agente que quisesse agir mal ou que por descuido inescusável agiu mal. O eixo de interesse da estrutura de responsabilização (penal ou civil) era o agente, e não sua vítima. Esta é, felizmente, até hoje a premissa pela qual se pauta o direito penal, razão pela qual não há um só autor penalista que defenda responsabilização penal objetiva.

Contudo, a responsabilidade civil, ao longo dos anos, e, graças ao intenso trabalho dogmático de autores renomados ${ }^{362}$, alterou radicalmente seu eixo de interesse, focalizando-o não mais exclusivamente no agente, mas principalmente na vítima. Daí que, para haver responsabilização civil, não importa se a conduta foi dolosa ou culposa, mas,

\footnotetext{
${ }^{362}$ No Brasil, esta viragem é atribuída, principalmente, a Alvino Lima. Cf.: Culpa e risco, São Paulo, Editora Revista dos Tribunais, 1960.
} 
fundamentalmente, se o dano sofrido pela vítima deve ou não ser suportado por ela, em resumo, se é justo ou injusto.

Portanto, diferentemente do que sustentam os defensores do "direito de danos", a tentativa de integração da função punitiva à responsabilidade civil é retrocesso científico e histórico que, ao invés de atender às vítimas, poderá dificultar sua indenização. Isso porque, caso se insista em punir o agente por meio da responsabilidade civil, fatalmente, será necessário trazer à baila a discussão sobre o valor ou desvalor da conduta, afinal só há sentido em punir ou, como alguns preferem, desestimular condutas que sejam em si mesmas reprováveis.

Desta forma, a introdução de sanção punitiva ao causador de determinados danos injustos no ordenamento jurídico brasileiro só pode ser feita por via própria e não por meio da responsabilidade civil.

Poderia, por exemplo, haver a inclusão de um parágrafo no artigo 944 do Código Civil autorizando que o magistrado, na análise do caso concreto e diante de determinadas circunstâncias, que devem ser balizadas pelo legislador, possa fixar multa ao causador do dano ${ }^{363}$, além, é claro, do valor devido a título de reparação do dano. $\mathrm{O}$ magistrado, assim, ficaria autorizado a aplicar ao causador do dano não só a sanção consistente no dever de indenizar o dano (artigo 944, caput, do Código Civil), mas também a sanção de multa.

\subsubsection{2. "Indenização" sem dano}

Ao lado da ideia de punição, há, como apontado, a tentativa de autorizar o Poder Judiciário a determinar que o agente "indenize" alguém sem que necessariamente haja dano. Se a inclusão da função punitiva à responsabilidade civil é criticável pelas

\footnotetext{
${ }^{363} \mathrm{O}$ antigo Projeto de Lei ${ }^{\circ}$ 6.960/2002 do deputado Ricardo Fiúza previa a inclusão de um $\S 2^{\circ}$ no artigo 944 do Código Civil com a seguinte redação: “\$2 A reparação do dano moral deve constituir-se em compensação ao lesado e adequado desestímulo ao lesante". Esse projeto de lei encontra-se arquivado, mas tramita na Câmara dos Deputados o Projeto de Lei no 699/2011, que mantém a mesma proposta do projeto Fiúza. Todavia, pelas razões expostas, esta redação não é adequada, porque nela a indenização teria seu valor indevidamente alargado. Propõem-se, aqui, duas sanções: a de indenização, e, em determinadas casos, também a sanção de multa - que teria finalidade punitiva e também dissuasória.
} 
razões há pouco articuladas, a ideia de "indenização" sem dano é, para dizer no mínimo, absurda.

O significado do verbo indenizar é o de tornar indene - do latim in dene -, retirar o dano. É, pois, impossível lógico retirar dano se dano não há para ser retirado.

Quando alguns autores defendem a possibilidade de indenização sem dano, ora o fazem porque desconhecem ou parecem desconhecer distinções dogmáticas, como a que há entre medida judicial preventiva e medida judicial satisfativa; ora o fazem porque não percebem que a situação que descrevem já é de dano e, portanto, estão defendendo o óbvio: indenização de dano.

Nas hipóteses expostas por Daniel de Andrade Levy da usina que despeja seus detritos no rio e, com isso, contamina as propriedades ribeirinhas e da usina que ainda não despejou seus detritos no rio, podem-se divisar claramente duas situações jurídicas distintas: uma constituída por um dano injusto e outra constituída por um perigo de dano. Para ambas, o autor busca solução no esquema de responsabilização civil, sem, ao que parece, lembrar que o sistema jurídico, não de hoje, já contempla soluções distintas para o dano e para o perigo de dano. Para o primeiro, há a indenização; para o segundo, os esquemas normativos de proibição de condutas capazes de gerar risco de dano injusto para situações jurídicas alheias e cujo esquema prototípico é o artigo 461 e parágrafos do Código de Processo Civil ${ }^{364}$, além, é claro, das regras previstas na Lei 7.357/85, que disciplina a ação civil pública.

364 “Art. 461. Na ação que tenha por objeto o cumprimento de obrigação de fazer ou não fazer, o juiz concederá a tutela específica da obrigação ou, se procedente o pedido, determinará providências que assegurem o resultado prático equivalente ao do adimplemento.

$\S 1^{\circ}$ A obrigação somente se converterá em perdas e danos se o autor o requerer ou se impossível a tutela específica ou a obtenção do resultado prático correspondente.

$\S 2^{\circ}$ A indenização por perdas e danos dar-se-á sem prejuízo da multa (art. 287).

$\S 3^{\circ}$ Sendo relevante o fundamento da demanda e havendo justificado receio de ineficácia do provimento final, é lícito ao juiz conceder a tutela liminarmente ou mediante justificação prévia, citado o réu. A medida liminar poderá ser revogada ou modificada, a qualquer tempo, em decisão fundamentada.

$\S 4^{\circ} \mathrm{O}$ juiz poderá, na hipótese do parágrafo anterior ou na sentença, impor multa diária ao réu, independentemente de pedido do autor, se for suficiente ou compatível com a obrigação, fixando-lhe prazo razoável para o cumprimento do preceito.

$\S 5^{\circ}$ Para a efetivação da tutela específica ou a obtenção do resultado prático equivalente, poderá o juiz, de ofício ou a requerimento, determinar as medidas necessárias, tais como a imposição de multa por tempo de atraso, busca e apreensão, remoção de pessoas e coisas, desfazimento de obras e impedimento de atividade nociva, se necessário com requisição de força policial. 
Aqueles que, como o autor, fazem menção à responsabilidade civil preventiva confundem, portanto, estas duas modalidades distintas de situações jurídicas ilícitas: a consistente no dano injusto, cujo elemento sistemático de estabilização é a indenização, imposta pela deflagração da estrutura de responsabilização civil; e a consistente na submissão de posição jurídica a risco de dano injusto, para a qual existem os elementos de prevenção e imunização de posição jurídica contra intromissões alheias indevidas, elementos esses já clássicos em nosso sistema jurídico ${ }^{365}$.

É evidente que, quando o autor fala que "o magistrado pode, além de determinar a imediata eliminação do risco, impor indenização que estimulasse o agente a tomar as medidas de prevenção necessárias para evitar, ao máximo, a futura ocorrência do dano”, a palavra indenização esta, aí, mal utilizada, pois só se retira ou afasta dano, quando há dano a ser afastado. O que se pretendeu dizer foi, simplesmente, que o juiz poderia impor ao réu o dever de pagar quantias em dinheiro até sanar a situação de criação indevida de riscos, o que, nem de longe, é indenização, e sim a já bastante velha astreinte.

No trabalho de Teresa Ancona Lopez, vê-se que, na passagem reproduzida acima em que a autora defende o "dano de risco", ela própria cuida de tratar o risco ou ameaça de dano como um dano injusto ${ }^{366}$, o que joga pá de cal na discussão, afinal, se há dano injusto, a solução é a indenização.

A obra de Teresa Ancona Lopez é dogmaticamente consistente, pois, embora em um primeiro momento pareça concordar com a possibilidade de responsabilização civil sem dano, cuida logo de enquadrar a "ameaça de dano" no rol dos danos injustos, restaurando, com isso, a coerência sistemática do esquema tradicional de responsabilização civil adotado pelo ordenamento jurídico brasileiro.

$\S 6^{\circ} \mathrm{O}$ juiz poderá, de ofício, modificar o valor ou a periodicidade da multa, caso verifique que se tornou insuficiente ou excessiva". Grifaram-se os dispositivos mais especificamente apropriados à questão da prevenção de danos injustos.

${ }^{365}$ Basta lembrar-se, além dos dispositivos citados do CPC, dos artigos 12, 20, 1.280, 1.308 etc. do Código Civil.

${ }^{366}$ A autora fala que: "O medo constante de ser portador de vírus de doença incurável é, com certeza, dano indenizável”. Op. cit., p. 139. Está-se, pois, diante de dano extrapatrimonial, consistente na lesão à integridade psíquica da pessoa. 
Com relação ao trabalho de Lucas Abreu Barroso e Pablo Malheiros da Cunha Frota, também aplicam-se as críticas feitas até aqui.

Como já anotado, os autores afirmam textualmente que o direito de danos busca "concretizar a responsabilidade sem danos, pois a possibilidade de sua verificação já acionaria o dever de reparar por parte daquele que possa vir a causá-lo" 367 . Perceba-se que os autores não se preocupam em dizer o que será reparado, afinal de contas eles mesmos dizem que não houve dano e, como, insistentemente, demonstrou-se, a indenização não é medida apta a sancionar condutas potencialmente causadoras de dano.

No caso da talidomida, que lhes serve de mote para a defesa do "direito de danos", os autores entendem ser necessário esse novo paradigma para permitir que se apliquem os princípios da prevenção e precaução e, assim, no caso, retirar a talidomida do mercado.

Evidentemente que, pelo menos desde a vigência do Código de Defesa do Consumidor $^{368}$, o ordenamento jurídico brasileiro já conta com instrumentos hábeis para determinar a retirada de produtos nocivos do mercado ${ }^{369}$. O artigo $6^{\circ}$, inciso VI desse diploma fala expressamente em prevenção de danos patrimoniais e morais, individuais, coletivos e difusos.

Além do que os documentos resultantes da Eco 92, já analisados, e que foram incorporados ao direito brasileiro, consagraram expressamente referidos princípios, não deixando margem a dúvidas: quando uma atividade é efetivamente perigosa ao meio ambiente, à saúde e à vida do ser humano, ou quando haja incerteza científica sobre seus efeitos, devem ser adotadas medidas para evitar consequências desastrosas.

Cumpre apontar também que, diferentemente do que sustentam os autores, o entendimento de que o Código de Defesa do Consumidor consagra o chamado "risco do

\footnotetext{
${ }^{367}$ BARROSO, Lucas Abreu; FROTA, Pablo Malheiros da Cunha, op. cit., p. 106.

${ }^{368}$ Pelo menos, porque o Código de Processo Civil de 1973 já continha a previsão de medidas cautelares.

369 Vide, por exemplo, artigo $6^{\circ}$, incisos I e VI; artigo $9^{\circ}$; artigo 10; artigo 83, artigo 84, caput e parágrafos do Código de Defesa do Consumidor.
} 
desenvolvimento" 370 como excludente do dever de indenizar não pode ser aceito à luz do ordenamento jurídico brasileiro, sendo desnecessário, mais uma vez, o recurso ao direito de danos para se chegar a esta conclusão.

De fato, há uma corrente que defende que o Código de Defesa do Consumidor permitiria a exclusão de responsabilidade civil do fornecedor pelo risco do desenvolvimento. Nesse sentido, argumenta-se que fazer o fabricante suportar esses riscos pode inviabilizar o progresso científico e tecnológico, já que, por não conhecê-los, ele não os internalizaria em seus custos e, consequentemente, não os dividiria com o consumidor $^{371}$.

Entretanto, as conquistas em matéria de direito do consumidor, embasadas em princípios cujo norte é, obviamente, a sua proteção, e, mais genericamente, em matéria de direito coletivo, com destaque para os princípios da prevenção e precaução e todas as construções que deles decorrem e que, inegavelmente, já se encontram incorporadas ao direito positivo brasileiro, não dão espaço para esse tipo de discurso.

Antônio Herman de Vasconcellos e Benjamin esclarece que:

"O Código não inclui, entre as causas exoneratórias, os riscos de desenvolvimento, isto é, os defeitos que - em face do estado da ciência e da técnica à época da colocação em circulação do produto ou serviço - eram desconhecidos e imprevisíveis. Por adotar um sistema de responsabilidade civil objetiva alicerçado no risco de empresa, a lei brasileira não podia, com razão, exonerar o fabricante, o produtor, o construtor e o importador na presença de um risco de desenvolvimento ${ }^{372}$.

$(\ldots)$

\footnotetext{
370 Não se entende ser pertinente, nesse estudo, fazer uma análise mais detida do risco do desenvolvimento. Apenas para aventar o conceito, segundo Antônio Herman de Vasconcellos e Benjamin, o risco do desenvolvimento é "o risco que não pode ser cientificamente conhecido no momento do lançamento do produto no mercado, vindo a ser descoberto somente após um certo período de uso do produto ou serviço. É defeito que, em face do estado da ciência e da técnica à época da colocação do produto ou serviço em circulação, era desconhecido e imprevisível". Comentário ao Código de Proteção do Consumidor, coordenação de OLIVEIRA, Juarez de, São Paulo, Saraiva, 1991, p. 67.

${ }^{371}$ Cf.: CAVALIERI FILHO, Sergio, op. cit., p. 177.

${ }^{372}$ Idem.
} 
Os defeitos decorrentes de risco de desenvolvimento representam uma espécie do gênero defeito de concepção. Só que aqui o defeito decorre da carência de informações científicas, à época da concepção, sobre os riscos inerentes à adoção de determinada tecnologia nova.

Se o fabricante de medicamentos conseguir provar que, à época da fabricação do produto, desconhecida seu potencial para causar defeitos genéticos, ainda assim será responsabilizado, posto que, ao fabricá-lo, assumiu todos os seus riscos. Há, ai, verdadeiro defeito de concepção",373.

Finalmente, também não há necessidade do chamado "direito de danos" para estabelecer a responsabilidade civil dos laboratórios. Claramente, a legislação buscou facilitar a indenização das vítimas da talidomida, concentrando na União o pagamento das indenizações. Mas isso não significa que a União esteja impedida de regressar contra os laboratórios. A hipótese em questão é a do parágrafo único do artigo 942 do Código Civil, que consagra responsabilidade civil solidária entre os responsáveis pela causação do dano (autores e coautores), no caso, entre a União, que autorizou a colocação da talidomida no mercado, e os laboratórios que comercializaram os medicamentos à base de talidomida. Aplicam-se, portanto, todos os efeitos da solidariedade.

Do exposto, reafirma-se que os chamados princípios da precaução e prevenção não têm o condão de ampliar o objeto da responsabilidade civil para que ela passe a abarcar hipóteses em que não haja dano injusto.

Reitere-se: os momentos antecedentes ao dano injusto e que são o locus proprium de tais princípios exigem mecanismos de estabilização social que, embora próximos, são inconfundíveis com os da responsabilidade civil. Se é verdade que o princípio geral do direito consubstanciado na fórmula neminem laedere é o fundamento comum tanto da prevenção/precaução como da reparação, também é certo que seus pressupostos são assaz distintos. Por imperativo lógico, insista-se, a indenização pressupõe

${ }^{373}$ Idem. 
a ocorrência de intromissão injusta e prejudicial na esfera jurídica alheia, enquanto que a precaução/prevenção exige uma ameaça de intromissão injusta.

Tanto a situação jurídica de dano injusto como a situação jurídica de ameaça de dano injusto devem ser anatematizadas por serem ilícitas, mas o meio de anatematização diferencia-se completamente. No primeiro caso, como foi dito, há a deflagração da estrutura de responsabilização civil que culminará na imposição do dever de indenizar; no segundo caso, haverá a deflagração de mecanismos de antecipação que são de existência indiscutível no ordenamento jurídico brasileiro, bastando que se lembre, uma vez mais, da chamada multa cominatória e de todos os outros consectários do poder geral que o juiz tem de conceder tutelas antecipadas, satisfativas e cautelares, positivados paradigmaticamente nos artigos 273, 461, 798 e 799, do Código de Processo Civil.

A tentativa de ampliação do objeto da responsabilidade civil, além de tecnicamente equivocada, tem o inconveniente de retirar a clareza conceitual das categorias jurídicas, o que é de todo desastroso para a solução dos problemas concretos.

Feitas essas análises pontuais da responsabilidade civil e das tentativas de modificá-la, cumpre, por derradeiro, enquadrá-la no sistema jurídico, para que, com isso, tenha-se uma visão global do instituto. 


\section{CAPÍTULO 5 - O DANO INJUSTO COMO PRESSUPOSTO DO DEVER DE INDENIZAR}

\subsection{A sanção própria da responsabilidade civil em sentido estrito: o dever de indenizar}

O enquadramento do instituto da responsabilidade civil no sistema jurídico requer, antes, a delimitação de sua sanção própria. Para tanto, será abordada a sanção do ponto de vista geral para, na sequência, especificar as principais sanções civis, com o que será possível extremá-las daquela própria da responsabilidade civil, a indenização.

\subsubsection{A sanção jurídica}

O vocábulo sanção tem origem latina no substantivo sanctio, onis, que inicialmente significava apenas ato de confirmar, ratificar, validar; no verbo sancire, consagrar, ordenar, decretar; e no adjetivo sanctus, isto é, santo, sagrado, inviolável, íntegro. Com a evolução da língua, à palavra sanctio, onis deu-se também o significado de punição, castigo; e, consequentemente, sancire também podia denotar punir, castigar. Daqui, resultou que a sanção da lei - o ato de sancioná-la - consiste em torná-la sagrada, inviolável, obrigatória. E ainda que sanção é a punição que a lei impõe àquele que a descumpre ${ }^{374}$.

Modernamente, o Direito toma a expressão sanção jurídica nestes dois sentidos, empregando-a, assim, ora para designar o ato pelo qual o chefe do Poder Executivo aprova o projeto de lei votado pelo Poder Legislativo, transformando-o definitivamente em lei, ora querendo significar a consequência negativa proveniente do descumprimento de uma norma jurídica.

374 MIOTTO, Armida Bergamini, Sanção penal - I, in Enciclopédia Saraiva do Direito, v. 67, coordenação de FRANÇA, Rubens Limongi, São Paulo, Saraiva, 1977, p. 25-26. 
Com relação à acepção político-constitucional da expressão sanção jurídica, ficar-se-á apenas nessa menção. Para o objetivo desse trabalho, interessa a análise da sanção enquanto conceito pertinente à estrutura da norma jurídica.

O cerne dos debates da teoria geral do direito e também de parte da filosofia do direito sempre foi a norma jurídica. A busca de um critério que, satisfatoriamente, conseguisse caracterizá-la acabou conferindo à sanção um papel de destaque ${ }^{375}$.

A esse respeito, Norberto Bobbio divide os filósofos do direito em "sancionistas" e "não sancionistas", querendo agrupá-los entre os que entendem que a sanção é elemento constitutivo do direito e os que a concebem como um elemento secundário $^{376}$.

Para os primeiros há, portanto, uma relação de interdependência entre norma jurídica e sanção. A completude da norma jurídica requer, segundo Kelsen, uma estrutura que deve conter, cumulativamente, uma norma secundária - que descreve um fato e prescreve um comportamento a ser seguido - e uma norma primária - que estabelece a sanção para o caso de descumprimento daquele comportamento previsto ${ }^{377}$. Na ausência dessa estrutura binária, estar-se-á diante do que os jurisconsultos romanos denominavam leges imperfectae.

\footnotetext{
${ }^{375}$ Sob o aspecto lógico-estrutural, diz-se que a norma jurídica é uma proposição prescritiva, cuja função é atuar sobre o comportamento dos indivíduos, ou dos grupos, para que sejam alcançados determinados objetivos. Ela pode ser traduzida, genericamente, na fórmula "Se é A, deve ser B", em que se descreve um suporte fático e se estabelece uma consequência jurídica. Mas é fácil constatar que esta estrutura da norma jurídica não é diversa daquela das demais normas existentes na vida dos homens. Daí terem surgido diferentes critérios para diferenciá-las. Bobbio elenca os principais critérios elaborados pela doutrina e elege o do tipo de resposta que os diversos sistemas normativos dão à sua violação como o melhor. BOBBIO, Norberto, Teoria geral do direito, $3^{\mathrm{a}}$ ed., tradução de Denise Agostinetti e revisão da tradução de Silvana Cobucci Leite, São Paulo, Martins Fontes, 2010.

${ }^{376}$ BOBBIO, Norberto, op. cit., p. 154 e seguintes. Dentre os autores sancionistas, pode-se citar o próprio Bobbio, Kelsen, e no direito pátrio Lourival Vilanova. BOBBIO, Norberto, op. cit. KELSEN, Hans, Teoria geral do Direito e do Estado, $4^{\mathrm{a}}$ ed. São Paulo, Martins Fontes, 2005. VILANOVA, Lourival, As estruturas lógicas e o sistema de direito positivo, São Paulo, Revista dos Tribunais, 1997. Já entre os não sancionistas estão: Larenz e Pontes de Miranda. LARENZ, Karl, Metodologia da ciência do direito, Lisboa, Fundação Calouste Gulbenkian, 1969. PONTES DE MIRANDA, Francisco Cavalcanti, Tratado de Direito Privado Parte Geral - Tomo I - Introdução. Pessoas físicas e jurídicas, $3^{\text {a }}$ ed., Rio de Janeiro, Borsoi, 1970.

${ }^{377}$ KELSEN, Hans, Teoria geral do Direito e do Estado, 4a ed. São Paulo, Martins Fontes, 2005. Observe que Kelsen qualifica de secundária a norma que descreve a conduta devida e de primária a norma que estatui a sanção para o caso de violação da conduta ordenada pela norma secundária. Esse entendimento é praticamente isolado na doutrina. Em geral, atribui-se um sentido inverso a esses termos, de modo que por norma primária entende-se a norma que estabelece a conduta ordenada como devida e por norma secundária a que fixa a sanção para o caso de descumprimento da norma primária. É preciso ressaltar, contudo, que, na Teoria geral das normas, obra posterior à Teoria pura do direito, Kelsen parece ter mudado seu posicionamento.
} 
A principal objeção utilizada pelos não sancionistas é o fato incontestável da existência de normas desprovidas de sanção em um ordenamento jurídico (as normas de direito público que têm função organizativa, por exemplo). Segundo essa corrente, basta para a caracterização da norma jurídica a descrição de uma hipótese de fato e a prescrição de consequências jurídicas, sejam elas sanção ou não.

Bobbio contra-argumenta sustentando que a essência da teoria sancionista é a existência do mecanismo da sanção institucionalizada no ordenamento jurídico considerado no seu todo e não com relação a uma norma singular, o que importa em afirmar que nem todas as normas precisam ser sancionadas, mas que a maior parte delas deva $\operatorname{ser}^{378}$.

Por sanção institucionalizada ou organizada, esclarece Bobbio, deve-se entender três coisas, que podem não estar presentes conjuntamente: (i) o estabelecimento da respectiva sanção para toda violação de uma regra primária, de modo que se tenha a certeza da resposta; (ii) o estabelecimento da medida da sanção, ainda que dentro de certos limites, para que se assegure a proporcionalidade entre a violação e a resposta; (iii) a designação do órgão encarregado de executar a sanção, a fim de garantir-se a imparcialidade ${ }^{379}$.

Para Bobbio, estas três limitações permitem diferenciar a sanção jurídica das demais sanções sociais. É que, diferentemente da sanção moral, que é uma sanção interna, pois que infligida pelo indivíduo a ele mesmo, tanto a sanção social quanto a sanção jurídica são sanções externas, isto é, respostas infligidas por outrem ao transgressor de uma norma. Mas, ao contrário da sanção social, a sanção jurídica é institucionalizada, o que acaba conferindo-lhe uma "eficácia reforçada" em relação às normas morais e sociais ${ }^{380}$.

Daqui já podem ser extraídas algumas características da sanção jurídica. Mas o qual é o seu conceito?

\footnotetext{
${ }^{378}$ BOBBIO, Norberto, op. cit., p. 158-169.

${ }^{379}$ BOBBIO, Norberto, ibid., p. 151-154.

${ }^{380}$ BOBBIO, Norberto, ibid., p. 146-154.
} 
Tradicionalmente, a doutrina sempre conceituou a sanção como a resposta do ordenamento jurídico à violação de suas normas ${ }^{381}$.

O sistema jurídico conhece a possibilidade de vir a ser violado, pois suas prescrições, sendo de dever ser, não correspondem, muitas vezes, à ação real - ser -, e para fazer frente a essa eventualidade, fixa as consequências no sentido de que haja uma recondução ao Direito ${ }^{382}$.

É dizer: concebe-se a sanção como o mecanismo de que se vale o ordenamento jurídico para neutralizar situações tidas como intoleráveis, configurem essas situações uma conduta (ação - ato ou atividade - ou omissão), um resultado ou ambos ${ }^{383}$. Assim, o ordenamento consegue garantir sua conservação, o que, aliás, é o fundamento da sanção.

Ao causador de um dano injusto, impõe-se o dever de indenizar. Ao homicida, aplica-se a pena privativa de liberdade. O contribuinte que paga o tributo após o

\footnotetext{
${ }^{381}$ Contemporaneamente, emprega-se o vocábulo sanção também para designar prêmios ou recompensas. Fala-se, assim, em sanção positiva ou premial. Isso se deve, principalmente, a uma mudança no estudo do direito, que de uma análise meramente estrutural ganhou também uma análise funcional. As teorias tradicionais do direito sempre lhe atribuíram uma finalidade essencialmente protetiva e repressiva, sendo essa, ainda hoje, a concepção predominante. Entretanto, com o aparecimento do Estado assistencial, foram introduzidas novas técnicas de controle social, que acresceram ao direito uma tarefa promocional. Isso se deu, sobretudo, por meio de medidas de estímulo ou incentivo destinadas a promover a realização de comportamentos considerados socialmente desejáveis, dentre as quais se destacam a concessão de prêmios como resultado de uma ação boa perante o direito. Dessa forma, alargou-se o conceito de sanção para nele incluir, não só consequências jurídicas negativas, mas também consequências jurídicas positivas. Por meio de incentivos os mais variados, o Direito logra obter aderência social às suas disposições não mais pela ameaça de um mal, mas pela promessa de um bem. BOBBIO, Norberto, Da estrutura à função: novos estudos de teoria do direito, tradução de Daniela Beccaccia Versiani, revisão técnica de Orlando Seixas Bechara e Renata Nagamine, Barueri - SP, Manole, 2007.

Do ponto de vista técnico, não é aconselhável utilizar o mesmo vocábulo - sanção - para designar eficácias normativas tão diversas. Contudo, valem aqui as observações de Menezes Cordeiro: "E quando uma nomenclatura esteja estabilizada: ainda que não seja a ideal, é de toda conveniência respeitá-la, de modo a não complicar a matéria com puras reconversões linguísticas". Tratado de direito civil português, v. II Direito das Obrigações, Tomo III - Gestão de negócios, enriquecimento sem causa, responsabilidade civil, Coimbra, Almedina, 2010, p. 289. Destarte, nesta dissertação, utilizar-se-á o termo sanção em sua concepção clássica de reação do sistema jurídico contra sua violação.

${ }^{382}$ BOBBIO, Norberto, Teoria geral do direito, $3^{\mathrm{a}}$ ed., tradução de Denise Agostinetti e revisão da tradução de Silvana Cobucci Leite, São Paulo, Martins Fontes, 2010, p. 152-154.

${ }^{3833}$ Maurício Bunazar expõe três hipóteses: valoração negativa da conduta e do resultado (dano injusto causado por conduta culposa ou dolosa); valoração negativa de um resultado apenas (dano injusto como resultado da conduta de estado de necessidade); valoração negativa da conduta apenas (vizinho que constrói obra com o fim exclusivo de impedir a passagem do sol e é condenado a desfazê-la antes mesmo de o sol aparecer). Taxonomia da sanção civil: para uma caracterização do objeto da responsabilidade civil, in Revista Juris da Faculdade de Direito, Fundação Armando Alvares Penteado, v. 5, janeiro a junho/2011, São Paulo, FAAP, 2010, p. 39-42.
} 
seu vencimento deve fazê-lo com o acréscimo de multa. O condutor do veículo que ultrapassa o sinal vermelho será multado e perderá pontos em sua carteira de habilitação. O servidor que comete falta grave pode ser demitido a bem do serviço público.

Essas explicações conduzem a uma importante constatação: toda contrariedade a direito é, pois, passível de sanção. Com essa afirmação quer-se dizer que o ordenamento jurídico confere ao legislador a possibilidade de instituir sanções sempre que tiver lugar uma ilicitude. Em regra, o legislador sanciona as condutas e/ou os resultados indesejáveis - afinal, se adotada uma posição sancionista, a maior parte das normas jurídicas singularmente consideradas devem ser providas de sanção - . Contudo, ainda que raramente, a ordem jurídica pode prescrever uma determinada conduta sem ligar a sua inobservância quaisquer consequências.

É o caso, por exemplo, da norma que reserva a uma coletividade - idosos, gestantes, portadores de deficiências e pessoas com crianças de colo - o uso preferencial de assentos nos meios de transporte coletivo. Está-se aqui diante de norma pertencente ao ordenamento jurídico para cujo descumprimento o legislador não estatuiu sanção. Provavelmente, se alguém que não se enquadre nesse grupo utilizar o assento preferencial na presença de pessoa a quem ele foi reservado, provocará um sentimento de repulsa, de reprovação nos demais usuários, mas essa reação configura uma sanção social apenas, a princípio, sem repercussão no mundo do direito.

Feitas essas breves considerações acerca dos aspectos gerais da sanção jurídica, cumpre analisar a espécie que interessa a esta dissertação: o dever de indenizar.

\subsubsection{O dever de indenizar enquanto espécie de sanção civil}

Sem pretensão de estabelecer uma classificação das sanções, mas, antes, querendo apresentar possíveis formulações para a norma jurídica, Bobbio afirma que há dois modos típicos com que o legislador faz operar a sanção em um ordenamento jurídico: 
"fazendo com que, ao violar a norma, não se alcance o fim a que se propunha"; e "fazendo com que, ao violar a norma, se alcance um fim oposto àquele a que se propunha" ${ }^{384}$.

No primeiro caso estão abrangidas aquelas sanções que fazem com que o infrator da norma primária simplesmente não alcance o objetivo pretendido. É o caso, por exemplo, da nulidade ou da anulação de um ato jurídico. A norma primária estabelece os requisitos para a realização do ato jurídico e a norma secundária faz com que, não preenchidos esses requisitos, o ato seja considerado juridicamente inválido ${ }^{385}$.

No segundo caso estão enquadradas as sanções que conferem ao transgressor da norma primária um fim diverso do pretendido. É o caso do dever de indenizar imposto àquele que, com sua conduta, causa um dano injusto ou, então, das penas privativas de liberdade aplicadas àqueles que cometem determinados crimes previstos nas normas penais.

Está-se aqui diante de uma possível classificação para as sanções jurídicas. Mas, como toda classificação, há muitos outros critérios que permitem agrupá-las.

Elas podem ser agrupadas, por exemplo, com base na divisão do direito em ramos. Fala-se, então, em sanções de direito civil, sanções de direito penal, sanções de direito tributário, sanções de direito administrativo, sanções de direito processual, sanções de direito constitucional etc.

O inconveniente dessa classificação é: há sanções que podem incidir sobre os mais diversos comportamentos transgressores de normas jurídicas, não importando por qual ramo eles sejam disciplinados. A multa é sanção aplicada a infrações de natureza cível, penal, fiscal, administrativa. Da mesma forma, a nulidade pode incidir não só sobre atos jurídicos de direito privado, mas também sobre atos administrativos e atos processuais.

\footnotetext{
384 BOBBIO, Norberto, Teoria geral do direito, $3^{\mathrm{a}}$ ed., tradução de Denise Agostinetti e revisão da tradução de Silvana Cobucci Leite, São Paulo, Martins Fontes, 2010, p. 106-111.

${ }^{385}$ Esse exemplo é o citado por Bobbio. Ibid., p. 110.
} 
De uma classificação, diz-se que é útil ou inútil. Como essa classificação não permite individuar o ramo jurídico a que pertence a sanção - vide o exemplo da multa - não auxilia na determinação do objeto da responsabilidade civil, pelo que buscar-se-á outra.

O critério mais utilizado pela doutrina é o que leva em conta a função desempenhada pela sanção.

José de Oliveira Ascensão elenca cinco espécies de sanção tendo em vista sua finalidade, quais sejam: compulsória, reconstitutiva, compensatória, preventiva e punitiva $^{386}$

Em sentido semelhante, embora se restringindo ao direito civil, Francisco Amaral arrola as seguintes modalidades de sanções: preventivas, restauradoras, indenizatórias, coativas e punitivas ${ }^{387}$.

Sanções preventivas são as que visam a evitar futuras violações à norma jurídica. Elas consistem em verdadeiras sanções, enfatiza Ascensão, pois representam uma reação à inobservância de uma regra. A interdição do exercício de profissão, por exemplo, é medida aplicada nas situações em que há receio de que a anterior prática do ilícito volte a ocorrer naquela atividade profissional ${ }^{388}$.

As sanções restauradoras ou reconstitutivas têm o objetivo de reconstituir a situação anterior ao fato danoso, como, por exemplo, reintegrar na posse do bem o possuidor que sofreu esbulho ${ }^{389}$.

Por sua vez, as sanções compensatórias ou indenizatórias, destinam-se a recompor o patrimônio do lesado no estado anterior à lesão. $\mathrm{O}$ devedor que não cumpre a prestação no tempo, lugar e forma devido responde por perdas e danos ${ }^{390}$.

\footnotetext{
386 ASCENSÃO, José de Oliveira, Introdução à Ciência do Direito, $3^{\mathrm{a}}$ ed. revista e atualizada, Rio de Janeiro, Renovar, 2005, p. 57-68.

${ }^{387}$ AMARAL, Francisco, op. cit., p. 101-103.

${ }^{388}$ ASCENSÃO, José de Oliveira, op. cit., p. 67-68.

${ }^{389}$ ASCENSÃO, José de Oliveira, ibid., p. 61.

${ }^{390}$ AMARAL, Francisco, op. cit., p. 102.
} 
As sanções compulsórias ou coativas almejam fazer com que o infrator da norma sinta-se compelido a cumpri-la, mesmo que a destempo. A prisão civil do devedor de alimentos é medida destinada a coagir o devedor ao cumprimento obrigacional ${ }^{391}$.

São punitivas as sanções que visam a infligir um castigo ao violador da norma, como ocorre, por exemplo, com a exclusão da herança do herdeiro indigno ${ }^{392}$.

Essa classificação das sanções jurídicas segundo a função que desempenham deve ser tomada com alguma ressalva. É preciso considerar que há sanções que encerram, ao mesmo tempo, mais de uma finalidade. À pena criminal a doutrina atribui, pelo menos, duas funções: a punitiva (inflição de um mal) e a preventiva, que se divide em prevenção geral (dirigida a todos os destinatários da norma penal) e especial (dirigida ao delinquente). De resto, todas as sanções contêm em si, ainda que indiretamente, um fim intimidativo, na medida em que, abstratamente consideradas, elas servem como um desestímulo à prática de condutas contrárias ao direito.

Maurício Bunazar, com base na obra de Pontes de Miranda ${ }^{393}$, elaborou uma taxonomia das sanções civis impostas pelo Código Civil brasileiro que leva em conta os seus efeitos ${ }^{394}$ :

${ }^{391}$ AMARAL, Francisco, ibid., p. 103.

${ }^{392}$ ASCENSÃO, José de Oliveira, op. cit., p. 66-67.

${ }^{393}$ Em várias passagens do Tratado de Direito Privado Pontes de Miranda faz alusão a diversos tipos de sanção: sanções penais e sanções não penais, tais como nulidade, anulabilidade, caducidade, ineficácia e, até mesmo, inexistência. Cf.: Tratado de Direito Privado - Parte Geral - Tomo II - Bens. Fatos Jurídicos, $3^{\mathrm{a}}$ ed., Rio de Janeiro, Borsoi, 1970, p. 104; Tratado de Direito Privado - Parte Especial - Tomo LIII - Direito das Obrigações: Fatos ilícitos absolutos. Atos-fatos ilícitos absolutos. Atos ilícitos absolutos. Responsabilidade. Danos causados por animais. Coisas inanimadas e danos. Estado e servidores. Profissionais, $3^{\mathrm{a}}$ ed., reimpressão, Rio de Janeiro, Borsoi, 1972, p. 192 e seguintes.

É preciso registrar que alguns autores não consideram as invalidades, a ineficácia e a inexistência como sanções. Nesse sentido, José de Oliveira Ascensão utilizando a expressão ineficácia de forma bastante ampla, para nela incluir não só a ineficácia propriamente dita, mas também a inexistência e as invalidades, sustenta que ela não representa uma sanção. Quanto à inexistência, aduz que se está diante de um nada jurídico, isto é, algo sem reconhecimento pela ordem jurídica. No que diz respeito às invalidades, argumenta que os requisitos a serem preenchidos para que um ato seja considerado válido representam requisitos de integração desse ato à ordem jurídica, de modo que, uma vez não devidamente preenchidos, o ato é considerado sem relevância na ordem jurídica, nada havendo que se reprovar. Com relação à ineficácia em sentido restrito, impede-se tão somente o ato de produzir seus efeitos, seja totalmente, seja parcialmente. ASCENÇÃO, José de Oliveira, Introdução à Ciência do Direito, $3^{\mathrm{a}}$ ed. revista e atualizada, Rio de Janeiro, Renovar, 2005, p. 68-74; O Direito. Introdução e teoria geral, $13^{\mathrm{a}}$ ed. refundida, Coimbra, Almedina, 2006, p. 78-80. Também rejeita-se nesse trabalho a tese de que a inexistência e a ineficácia sejam sanções jurídicas, mas se reconhece que as invalidades têm natureza sancionatória.

394 BUNAZAR, Maurício, Taxonomia da sanção civil: para uma caracterização do objeto da responsabilidade civil, in Revista Juris da Faculdade de Direito, Fundação Armando Alvares Penteado, v. 5, janeiro a junho/2011, São Paulo, FAAP, 2010, p. 39-42. Conforme salienta o autor, esse rol não é exaustivo. 
(i) sanção consistente na invalidação de ato jurídico em sentido estrito ou negócio jurídico: declaração de nulidade de negócio jurídico celebrado por pessoa absolutamente incapaz (artigo 166, inciso I) ou anulação de negócio jurídico eivado de vício resultante de erro, dolo, coação, estado de perigo, leão ou fraude contra credores (artigo 171, II);

(ii) sanção consistente na perda de uma posição jurídica ativa (sanção caducificante): perda do poder familiar (artigo 1.638, incisos I-IV), exclusão da herança de herdeiro ou legatários declarados indignos (artigo 1.814, incisos I-III);

(iii) sanção consistente na imposição do dever de imputação patrimonial a título de pena (multa em sentido estrito): pagamento da dívida em dobro pelo credor que demandar dívida já paga (artigo 940);

(iv) sanção consistente na imposição do dever de fazer ou não fazer algo sem que necessariamente tenha ocorrido ou antes que ocorra dano injusto: reparação, pelo dono, do prédio vizinho que ameaça ruína (artigo 1.280);

(v) sanção consistente na imposição do dever de fazer algo a título de indenização: indenização imposta ao causador de um dano injusto (artigo 927).

$\mathrm{O}$ autor insere todas essas espécies de sanções dentro daquilo que denomina "responsabilidade civil em sentido amplo". A responsabilidade civil em sentido estrito, segundo ele, tem como única sanção a consistente no dever de indenizar ${ }^{395}$.

A classificação de Maurício Bunazar, ainda que exemplificativa, permite evitar confusões, como a que enquadra como indenização toda condenação a pagar valores, sem perceber, por exemplo, que pode tratar-se de multa.

Parece ser este o equívoco de José Luiz Gavião de Almeida ${ }^{396}$, que, buscando defender a ideia - correta - de que não existe responsabilidade civil sem dano,

\footnotetext{
${ }^{395}$ BUNAZAR, Maurício, Idem.
} 
engloba no campo da responsabilidade civil todas as respostas sancionadoras do Código Civil, tratando como "dano" a situação jurídica que a norma que contém a sanção pretende rechaçar.

No item número 9 de sua tese, José Luiz Gavião de Almeida busca demonstrar que, embora alguns institutos do Código Civil aparentemente tratem de responsabilidade civil sem dano, o que há, na verdade, é dano presumido.

O autor enquadra nesta situação, dentre outras, as hipóteses previstas nos artigos $940^{397}, 773^{398}, 1.992^{399}, 588^{400}$ e $883^{401}$, todos do Código Civil ${ }^{402}$. Contudo, essas hipóteses não são objeto da responsabilidade civil em sentido estrito e tampouco contêm qualquer presunção de dano.

Esses dispositivos arrolados pelo autor podem ser distribuídos em três grupos a partir da consequência decorrente da realização da conduta que descrevem. $\mathrm{O}$ primeiro grupo é formado pelos artigos 940 e 773; o segundo, pelos artigos 1.992 e 883 e, finalmente, o terceiro grupo, que contém apenas o artigo 588.

O primeiro grupo (artigos 940 e 773) caracteriza-se por impor como sanção multa, que nada tem a ver com qualquer prejuízo sofrido pelo beneficiário. O que o legislador pretende nestes dispositivos é, apenas, sancionar o comportamento reprovável do agente, sem qualquer consideração acerca das consequências que deste comportamento resultaram para aquele que fará jus aos valores. Porém, se do comportamento do agente

396 Responsabilidade civil sem dano no Código Civil de 2002, São Paulo, 2011, tese apresentada à Faculdade de Direito da Universidade de São Paulo como requisito parcial à obtenção do cargo de professor titular.

397 “Art. 940. Aquele que demandar por dívida já paga, no todo ou em parte, sem ressalvar as quantias recebidas ou pedir mais do que for devido, ficará obrigado a pagar ao devedor, no primeiro caso, o dobro do que houver cobrado e, no segundo, o equivalente do que dele exigir, salvo se houver prescrição".

398 "Art. 773. O segurador que, ao tempo do contrato, sabe estar passado o risco de que o segurado se pretende cobrir, e, não obstante, expede a apólice, pagará em dobro o prêmio estipulado".

399 "Art. 1.992. O herdeiro que sonegar bens da herança, não os descrevendo no inventário quando estejam em seu poder, ou, com o seu conhecimento, no de outrem, ou que os omitir na colação, a que os deva levar, ou que deixar de restituí-los, perderá o direito que sobre eles lhe cabia".

400 “Art. 588. O mútuo feito a pessoa menor, sem prévia autorização daquele sob cuja guarda estiver, não pode ser reavido nem do mutuário, nem de seus fiadores”.

401 “Art. 883. Não terá direito à repetição aquele que deu alguma coisa para obter fím ilícito, imoral, ou proibido por lei.

Parágrafo único. No caso deste artigo, o que se deu reverterá em favor de estabelecimento local de beneficência, a critério do juiz".

${ }^{402}$ Respeitou-se a ordem de exposição dos artigos adotada pelo autor. 
resultar dano, por exemplo, moral, além dos valores que deverá a título de multa, deverá indenização. Pense-se, por exemplo, num morador de condomínio edilício que urine na piscina. Além de passar a ser devedor de obrigação de fazer, consistente em repor a piscina em seu statu quo ante (indenização), poderá ser multado.

O segundo grupo (artigos 1.992 e 883) caracteriza-se por impor como sanção a perda de posição jurídica ativa ou, na linguagem de Pontes de Miranda, caducidade $^{403}$. A perda de posição jurídica ativa como consequência de dado comportamento reprovável também não se enquadra na lógica da responsabilidade civil, uma vez que sua finalidade é simplesmente sancionar conduta reprovável, e não reparar qualquer prejuízo causado à vítima. Isto fica claro se se perceber que, além dos artigos apontados pelo autor, é exemplo de caducidade a sanção de indignidade (artigos 1.814 a 1.818). Imagine-se que um de dois irmãos é comprovadamente responsável pelo assassínio dos pais e, portanto, declarado indigno. Diante desta hipótese, é perfeitamente possível que, além de perder o direito à parte dos bens que lhe caberiam (caducidade pela indignidade), seja condenado a pagar ao irmão indenização por danos materiais e/ou morais.

Vê-se, pois, que a multa e a caducidade são sanções que nada têm a ver com a responsabilidade civil em sentido estrito, o que fica evidenciado pelo fato de poderem ser impostas sem que haja qualquer prejuízo a quem quer que seja e também pelo fato de poderem ser cumuladas com a sanção de indenização.

Finalmente, o terceiro grupo (art. 588) não contém qualquer sanção, nem mesmo de caducidade, uma vez que, por lógica, só se pode perder posição ativa quando tal posição ativa haja existido. A hipótese descrita no artigo 588 não visa a punir alguém por ter realizado conduta proibida ou, em outras palavras, não estabelece a ilicitude de emprestar-se a menor. Apenas caracteriza como obrigação natural o empréstimo feito à pessoa menor. Tanto não é hipótese de sanção que se o menor, espontaneamente, pagar o que recebeu em empréstimo não poderá, por si ou seus representantes, reaver os valores que pagou.

\footnotetext{
${ }^{403}$ PONTES DE MIRANDA, Francisco Cavalcanti, Tratado de Direito Privado - Parte Geral - Tomo II - Bens. Fatos Jurídicos, $3^{\text {a }}$ ed., Rio de Janeiro, Borsoi, 1970.
} 
Depois de analisarem-se algumas das principais modalidades de sanção civil, extremando-as da indenização, cumpre, por derradeiro, apresentar a responsabilidade civil a partir da perspectiva global de seu locus no ordenamento jurídico brasileiro.

Para tanto, e por tratar-se de um desafio eminentemente sistemático, elegeuse como instrumental teórico a teoria dos sistemas de Luhmann. A escolha deste marco teórico deveu-se unicamente ao fato de que sua abordagem permite enxergar com clareza tanto a coerência da atual estrutura de responsabilidade civil quanto a impossibilidade de sua ampliação sem incoerência sistemática.

\subsection{O dano injusto como código comunicacional próprio da responsabilidade civil}

Neste item final da dissertação, a compreensão do direito como sistema apresenta-se como abordagem apropriada à demonstração da imprescindibilidade do dano injusto para a deflagração da responsabilização civil em sentido estrito.

Niklas Luhmann, Antonio Junqueira de Azevedo e, principalmente, Gunther Teubner fornecem elementos teóricos capazes de provar que qualquer sistema autônomo, como o Direito, possui formas próprias tanto para a captação de influências oriundas do meio envolvente ${ }^{404}$, como para a incorporação de tais influências ao seu meio.

Compreendendo-se o direito como um sistema de segundo grau ${ }^{405}$, isto é, sistema que, embora autônomo, está em função de um sistema de primeiro grau, no caso, a

\footnotetext{
${ }^{404}$ Gunther Teubner afirma que: “O Direito não é determinado nem por autoridades terrestres, nem pela autoridade dos textos, nem tão-pouco pelo direito natural ou por revelação divina: o Direito determina-se a ele mesmo por auto-referência, baseando-se na sua própria positividade". $O$ direito como sistema autopoiético, tradução e prefácio de José Engrácia Antunes, Lisboa, Fundação Calouste Gulbenkian, 1989, p. 2. Nesta linha, Antonio Junqueira de Azevedo afirma que "a manutenção da identidade e autonomia do sistema jurídico exige o respeito às suas formas". O direito como sistema complexo e de $2^{a}$ ordem; sua autonomia. Ato nulo e ato ilícito. Diferença de espírito entre responsabilidade civil e penal. Necessidade de prejuízo para haver direito de indenização na responsabilidade civil (parecer), in Estudos e pareceres de direito privado, São Paulo, Saraiva, 2004, p. 27.

${ }^{405}$ Teubner assevera que "o Direito constitui um sistema autopoiético de segundo grau, autonomizando-se em face da sociedade, enquanto sistema autopoiético de primeiro grau, graças à constituição auto-referencial dos seus próprios componentes sistêmicos e à articulação destes num hiperciclo”. Op. cit., p. 53. Niklas Luhmann, após afirmar que a sociedade é um sistema social, conclui que "o direito tem que ser visto como uma estrutura cujos limites e cujas formas de seleção são definidas pelo sistema social. (...). O direito é imprescindível enquanto estrutura, porque sem a generalização congruente de expectativas comportamentais normativas os homens não podem orientar-se entre si, não podem esperar suas expectativas". LUHMANN,
} 
sociedade, demonstra-se com mais facilidade as condições e consequências de sua comunicação com outros sistemas e até mesmo com seu meio envolvente.

O sistema jurídico é composto de variados elementos ${ }^{406}$ entre os quais cumpre, aqui, destacar os ramos dogmáticos criados por meio da interação de leis, doutrina e jurisprudência. Estes diversos ramos dogmáticos surgem e são reconhecidos apenas quando se pode neles visualizar um sistema, estruturado por órgãos e princípios próprios capazes de diferenciá-los dos demais ramos da dogmática. Evidentemente, cada um destes ramos da dogmática exerce uma função própria, consistente, no mínimo, em orientar os intérpretes e aplicadores do direito.

Então, pode-se divisar no sistema jurídico a existência de vários sistemas menores, que, no entanto, são dependentes dele, é dizer, não são autônomos. Os vários ramos em que se divide tradicionalmente a dogmática jurídica, com base naquela divisão fundamental em direito público e direito privado, são exemplos de sistemas menores, assim, o direito penal, o direito processual, o direito tributário e o direito civil.

Procedendo-se a uma análise mais minuciosa, é possível, ainda, identificar, dentro de cada um daqueles ramos da dogmática, sistemas vários que, dependentemente deles, compõem-nos. Cingindo a afirmação ao direito civil, pode-se verificar a presença de um sistema de direito patrimonial e um de direito existencial, os quais por suas vezes são compostos de outros sistemas ainda menores. No caso do direito existencial, são exemplos os direitos de personalidade e o direito pessoal de família; no direito patrimonial, o direito das coisas e o direito obrigacional ${ }^{407}$, este último, tradicionalmente estruturado sobre a responsabilidade obrigacional e extraobrigacional.

A esta altura, pode-se perguntar: qual é o fator que permite identificar e, com isso, diferenciar um sistema de outros?

Niklas, Sociologia do direito I, tradução de Gustavo Bayer, Rio de Janeiro, Edições Tempo Brasileiro, 1983, p. 168 e 170.

${ }^{406}$ Vide por todos Antonio Junqueira de Azevedo, O direito como sistema complexo e de $2^{a}$ ordem; sua autonomia. Ato nulo e ato ilícito. Diferença de espírito entre responsabilidade civil e penal. Necessidade de prejuízo para haver direito de indenização na responsabilidade civil (parecer), in Estudos e pareceres de direito privado, São Paulo, Saraiva, 2004, p. 26.

${ }^{407}$ Canaris fala expressamente em sistema de direitos reais e sistema de direito das obrigações. Cf.: Pensamento sistemático e conceito de sistema na ciência do direito, $4^{a}$ ed., tradução de António Menezes Cordeiro, Lisboa, Fundação Calouste Gulbenkian, 2008, p. 115 e 143. 
Com Luhmann e Teubner, pode-se dizer que tal fator é um código próprio de comunicação ${ }^{408}$. Um sistema se individualiza e se autonomiza do sistema que constitui seu meio envolvente quando cria um código próprio de comunicação com o qual "traduz" as informações externas para sua linguagem e, com isso, e após tal tradução, incorpora-as ou as rechaça ${ }^{409}$.

Luhmann, tratando da diferenciação da sociedade em relação ao ambiente, diz que:

"Pelo termo sociedade há que entender o sistema que compreende todo o tipo de comunicações, que reproduz a comunicação por meio da comunicação e desta forma se distingue dum ambiente. Seja qual for a nossa opinião a respeito desta concepção no contexto de uma teoria sociológica, é inegável que nos oferece um conceito claro da operação que produz e reproduz o sistema e, portanto, também um conceito dos limites e do ambiente de um sistema ${ }^{410}$,

Em outra obra, mas sobre o mesmo tema, Luhmann escreve que:

"A distinção, em teoria dos sistemas, entre auto-referência e heterorreferência nada nos diz em relação à questão de como o mesmo determina o mesmo, ou dito de outra forma, de como se reconhece a forma de acoplamento de operações dentro do sistema, e como a diferença entre sistema e meio é produzida e continuamente reproduzida. Isso ocorre, no caso típico de sistemas de função por meio de um código binário, que fixa um valor positivo e um valor negativo, excluindo a terceira

\footnotetext{
408 Teubner diz que "a base reprodutiva desses sistemas sociais (incluindo interação, organização, sociedade geral) é constituída pelo sentido (...) e seus elementos constitutivos são comunicações (...)”. Op. cit., p.64.

409 Teubner, baseado em Luhmann, reconhece que a identificação do direito dá-se por meio de uma comunicação baseada na distinção básica legal/ilegal. Em suas palavras: "através da aplicação da sua própria distinção entre legal/ilegal, o sistema jurídico constrói-se a si mesmo na base de um círculo auto-referencial". Ibid, p. 24.

${ }_{410}$ LUHMANN, Niklas, A improbabilidade da comunicação, $4^{\mathrm{a}}$ ed., tradução de Anabela Carvalho, Lisboa, Vega - Passagem, 2006, p.129.
} 
possibilidade. $\mathrm{O}$ valor positivo descreve a capacidade existente no sistema de acoplamento das operações, ou seja, aquilo com base no qual algo pode ser iniciado. $\mathrm{O}$ valor negativo serve apenas como índice para refletir as condições sob as quais o valor positivo pode ser estabelecido. O código, assim, é uma forma de dois lados, uma distinção cujo lado interno prevê que existe o lado externo ${ }^{411,}$,

Visto que cabe a dado código comunicacional estabelecer a identificação e diferenciação de um sistema, pode-se afirmar a contrario sensu, então, que um sistema é dependente de outro quando seu código comunicacional, embora capaz de destacá-lo, seja baseado no código comunicacional do sistema do qual se originou.

Voltando àqueles sistemas que formam os diversos ramos da dogmática jurídica, pode-se, repita-se, perceber dentro de cada um deles a existência de sistemas menores que os compõem. Tomando-se o direito civil como exemplo, tem-se que, dependentes dele, existem vários sistemas menores, como o contratual e o de família, perfeitamente identificáveis por seus códigos comunicacionais próprios.

Porém, pode ocorrer de acentuar-se a tal ponto a diferenciação de um sistema menor componente de um sistema formador de um ramo da dogmática que isso acabe gerando, para utilizar a linguagem de Luhmann, seu desacoplamento, é dizer, sua emancipação daquele ramo e, consequentemente, a formação de ramo dogmático próprio, tal qual se deu com o direito do consumidor, mas, para tanto, é necessário, reitere-se, que surja um código comunicacional próprio independente do código comunicacional do sistema do qual se desacoplou.

${ }^{411}$ LUHMANN, Niklas, A realidade dos meios de comunicação, tradução Ciro Marcondes Filho, São Paulo, Paulus, 2005, 37-38. Orlando Villas Bôas Filho aclara que: “a codificação binária da comunicação jurídica é compreendida por Luhmann como a forma estrutural que garante a própria autopoiese do sistema, pois, ao instituir um valor positivo (lícito) e um valor negativo (ilícito), o código, que ademais somente pode ser manejado no plano da observação de segunda ordem, permite ao sistema jurídico classificar as condutas como estando de acordo ou em desacordo com o direito". Teoria dos sistemas e o direito brasileiro, São Paulo, Saraiva, 2009, p.145. 
Buscando dar concretude à exposição, com a inclusão da temática própria desta dissertação, pode-se dizer que especificamente no que toca à responsabilidade civil, o quadro sistemático atual apresenta-se da seguinte forma:

A partir da sociedade, sistema social de primeiro grau, forma-se o Direito, sistema social de segundo grau, identificado e, no caso, autonomizado por seu código comunicacional próprio, isto é, legal/ilegal. Dentro do Direito e dele dependente, tem-se o surgimento de uma série de sistemas menores, conhecidos como ramos do direito ou ramos da dogmática jurídica, por exemplo, o direito penal e o direito civil.

Partindo-se, agora, do direito civil como sistema que, ao lado do código legal/ilegal, vale-se de um código próprio (direito comumldireito especial) para determinar o que faz e o que não faz parte do seu conteúdo, pode-se descer ao sistema de direito obrigacional cujo código comunicacional é adimplemento/inadimplemento (legal/ilegal especificado em comum/incomum e em adimplemento/inadimplemento). Do sistema obrigacional, chega-se ao sistema de responsabilidade civil, que, ao que parece, dele emancipou-se. Caso o adimplemento/inadimplemento refira-se a um dever obrigacional, o tipo de responsabilidade civil é obrigacional; se o adimplemento/inadimplemento refere-se ao dever genérico neminem laedere, a responsabilidade civil é de tipo extraobrigacional.

Do que se expôs, decorre que a responsabilidade civil é ainda e por enquanto sistema pertencente ao direito civil que, ao lado do código direito comum/direito especial, possui um código comunicacional próprio. Qual seja esse código é justamente o objeto dessa dissertação.

Como já se afirmou alhures, toda a responsabilidade civil estrutura-se a partir da noção da justiça ou injustiça do dano, sendo este seu específico código comunicacional.

Ora, a partir da função do sistema jurídico especializam-se os ramos da dogmática jurídica justamente por possuírem funções especiais geradoras do código comunicacional próprio. Como visto, a função da responsabilidade civil é o restabelecimento do equilíbrio social abalado pela causação de um dano injusto, daí a existência do código dano justo/dano injusto. 
Quando a doutrina e a jurisprudência - ambos elementos do sistema jurídico - buscam ampliar a função da responsabilidade civil, seja por meio da introdução da função de punição, seja por meio da introdução da função de prevenção, acabam por exigir um novo código comunicacional, o qual, se conquistado, implicará a criação de um novo sistema menor, dependente ou independente do sistema de direito civil, mas, de qualquer forma, distinto do sistema menor de responsabilidade civil.

Isto significa que a responsabilidade civil atingiu, graças ao seu código comunicacional próprio, grau de distinção capaz de fazê-la reconhecível dentro do sistema de direito civil. Em razão desta distinção e da importância do tema na sociedade contemporânea, ao que tudo indica, a responsabilidade civil tende a autonomizar-se do direito obrigacional.

Tudo isso serve para demonstrar a absoluta impossibilidade de ampliar objeto e função da responsabilidade civil sem desnaturá-la como responsabilidade civil. Caso se chegue a reconhecer normativamente a função punitiva - dita também pedagógica ou de desestímulo - da responsabilidade civil ocorrerá um conflito sistêmico entre sistema de reparação de danos e sistema de punição por causação de danos, o qual acabará por ser resolvido em nível doutrinário e jurisprudencial por meio de distinções, é dizer, doutrina e jurisprudência produzirão enunciados como "ao lado da função de reparação há, em sede de responsabilidade civil, a função de desestímulo" ou "o quantum da indenização é suficiente a reparar a vítima e desestimular o autor de praticar novas condutas lesivas".

Essa diferenciação apenas produzirá um elemento novo que ou se anexará a outros sistemas punitivos existentes mesmo ao nível do direito civil, ou se diferenciará e individualizará a ponto de criar um sistema menor próprio que de toda forma será distinto do de responsabilidade civil.

A reparação de danos continuará a gravitar em torno do código comunicacional dano justo/dano injusto, sendo certo que caso se queira chamar de responsabilidade civil a um sistema que contemple outras funções como a punitiva, apenas 
se estará dando velho nome a coisa nova, sem qualquer alteração da essência das coisas, afinal já disse Shakespeare ${ }^{412}$ :

"What's Montague? it is nor hand, nor foot, Nor arm, nor face, nor any other part

Belonging to a man. $\mathrm{O}$, be some other name!

What's in a name? that which we call a rose,

By any other name would smell as sweet;"

${ }^{412}$ SHAKESPEARE, William, Romeo and Juliet, act II, scene II, Leipzig, B. G. Teubner, 1859. 


\section{CONCLUSÃO}

O estudo realizado permitiu que se chegasse às seguintes conclusões:

1. A estrutura de responsabilidade civil aquiliana, no sistema jurídico brasileiro, assenta-se sobre três pressupostos: conduta, dano injusto e nexo de causalidade, e tem como sanção única o dever de indenizar. A conduta deve ser entendida como toda ação - ato ou atividade - ou omissão voluntária do agente, que pode configurar-se, ou não, como ilícita. Por sua vez, o dano injusto é o dano que o ordenamento jurídico entende que não deve ser suportado pela vítima e que, portanto, deve ser reparado. Já o nexo de causalidade é a relação normativa estabelecida entre a conduta e o dano injusto.

2. Todos esses pressupostos devem necessariamente estar presentes para que surja o dever de indenizar. Assim, não é possível falar-se, como defendem alguns doutrinadores, em responsabilidade civil sem nexo de causalidade ou sem dano.

3. As propostas de ampliação da função da responsabilidade civil, de modo a fazer com que ela, além de reparar danos injustos, passe também a preveni-los sustentado-se, inclusive, que o agente "indenize" na ausência de dano - e a punir o causador de danos injustos - punitive damages -, mostram-se incoerentes sob uma perspectiva sistemática.

4. A responsabilidade civil é um subsistema do direito civil, apoiado sobre o código comunicacional dano justo/dano injusto, e sua finalidade é a reparação de danos injustos. Já os princípios da prevenção e da precaução revelam-se como institutos multidisciplinares, que operam não só na seara jurídica, mas em vários níveis sociais.

5. Da mesma forma que a responsabilidade civil, os princípios da prevenção e da precaução também estão funcionalizados ao princípio do neminem laedere, mas cada um a seu modo. Trata-se de institutos distintos, contudo interdependentes, havendo entre eles uma relação de subsidiariedade, que pode ser enunciada da seguinte forma: a estrutura de responsabilização civil somente será deflagrada se não houver, ou se falhar, o esquema antecedente de prevenção/precaução. 
6. É possível que o sistema jurídico autorize a punição daquele que causa danos injustos, contudo, estar-se-á diante de outra sanção - por exemplo, multa -, distinta, da do dever de indenizar e não abrangida pelo instituto da responsabilidade civil. 


\section{BIBLIOGRAFIA}

ABBAGNANO, Nicola, Dicionário de filosofia, $5^{\mathrm{a}}$ ed., tradução da $1^{\mathrm{a}}$ edição brasileira coordenada e revista por Alfredo Bossi, revisão da tradução e tradução dos novos textos Ivone Castilho Benedetti, São Paulo, Martins Fontes, 2007.

ALMEIDA, José Luiz Gavião de, Responsabilidade civil sem dano no Código Civil de 2002, São Paulo, 2011, tese apresentada à Faculdade de Direito da Universidade de São Paulo como requisito parcial à obtenção do cargo de professor titular.

ALMEIDA, Silmara Juny de Abreu Chinellato e, Reprodução humana assistida: aspectos civis e bioéticos, tese apresentada ao Departamento de Direito Civil da Faculdade de Direito da Universidade de São Paulo para concurso de livre-docência, 2000.

ALVES, José Carlos Moreira, Direito romano, v. 1, 7ª ed., Rio de Janeiro, Forense, 1990. Direito romano, v. 2, $4^{\text {a }}$ ed., Rio de Janeiro, Forense, 1986.

ALVIM, Agostinho, Da inexecução das obrigações e suas consequências, $2^{\mathrm{a}}$ ed., São Paulo, Saraiva,1955.

AMARAL, Francisco, Direito civil: introdução, $7^{\text {a }}$ ed. rev., atual. e aum., Rio de Janeiro, Renovar, 2008.

ARISTÓTELES, Física I-II, prefácio, tradução, introdução e comentários de Lucas Angioni, Campinas, Editora da Unicamp, 2009.

ASCARELLI, Tullio, O empresário, tradução de Fábio Konder Comparato, in Revista de Direito Mercantil, Industrial, Econômico e Financeiro, v. 36, n. 109, São Paulo, jan./mar. 1998, p. 183-189.

A atividade do empresário, tradução de Erasmo Valladão Azevedo e Novaes França, in Revista de Direito Mercantil, Industrial, Econômico e Financeiro, v. 42, n. 132, São Paulo, out./dez. 2003, p. 203-2015.

ASCENSÃO, José de Oliveira, Introdução à Ciência do Direito, $3^{\mathrm{a}}$ ed. revista e atualizada, Rio de Janeiro, Renovar, 2005.

O Direito. Introdução e teoria geral, $13^{\mathrm{a}}$ ed. refundida, Coimbra, Almedina, 2006. 
Direito Civil - Teoria Geral: Introdução. As pessoas. Os bens, v. I, $3^{\text {a }}$ ed., São Paulo, Saraiva, 2010.

AZEVEDO, Álvaro Villaça, Teoria Geral das Obrigações e Responsabilidade Civil, $11^{a}$ ed., São Paulo, Atlas, 2008.

AZEVEDO, Antônio Junqueira, $O$ direito como sistema complexo e de $2^{a}$ ordem; sua autonomia. Ato nulo e ato ilícito. Diferença de espírito entre responsabilidade civil e penal. Necessidade de prejuízo para haver direito de indenização na responsabilidade civil (parecer), in Estudos e pareceres de direito privado, São Paulo, Saraiva, 2004, p. 2537.

- Responsabilidade civil ambiental. Reestruturação societária do grupo integrado pela sociedade causadora do dano. Obrigação solidária do causador indireto do prejuízo e do controlador de sociedade anônima. Limites objetivos dos contratos de garantia e de transação. Competência internacional e conflito de leis no espaço. Prescrição na responsabilidade ambiental e nas ações de regresso (parecer), in Novos Estudos e Pareceres de Direito Privado, São Paulo, Saraiva, $1^{\mathrm{a}}$ ed., $2^{\mathrm{a}}$ tiragem, 2010, p. $395-426$.

Por uma nova categoria de dano na responsabilidade civil: o dano social, in Novos Estudos e Pareceres de Direito Privado, $1^{\mathrm{a}}$ ed., $2^{\mathrm{a}}$ tiragem, São Paulo, Saraiva, 2009, p. 377-384.

BARROSO, Lucas Abreu; FROTA, Pablo Malheiros da Cunha, A obrigação de reparar por danos resultantes da liberação do fornecimento e da comercialização de medicamentos, in Revista Trimestral de Direito Civil, ano 11, v. 43, julho a setembro de 2010, p. 99-114.

BAVIERA, Johannes, Fontes Ivris Romani Antejvstiniani (FIRA) - Pars Altera Avctores, Firenze, G. Barbèra, 1940.

BENJAMIN, Antônio Herman de Vasconcellos e, [et al.], Comentário ao Código de Proteção do Consumidor, coordenação de OLIVEIRA, Juarez de, São Paulo, Saraiva, 1991.

BETANCOURT, Fernando, Derecho romano clásico, Sevilla, Universidad de Sevilla Secretariado de Publicações, 2001. 
BEVILAQUA, Clóvis, Theoria Geral do Direito Civil, 2ª ed., Rio de Janeiro, Livraria Francisco Alves, 1929.

BIONDI, Biondo, Instituizioni di Diritto Romano, 2ª ed., Milano, s.e., 1952.

BITTAR, Carlos Alberto, Os direitos da personalidade, $3^{\mathrm{a}}$ ed. revista e atualizada, Rio de Janeiro, Forense Universitária, 1999.

BOBBIO, Norberto, Teoria geral do direito, $3^{\mathrm{a}}$ ed., tradução de Denise Agostinetti e revisão da tradução de Silvana Cobucci Leite, São Paulo, Martins Fontes, 2010.

. Da estrutura à função: novos estudos de teoria do direito, tradução de Daniela

Beccaccia Versiani, revisão técnica de Orlando Seixas Bechara, Renata Nagamine, Barueri, Manole, 2007.

BOITEUX, Elza Antonia Pereira Cunha, A função ética da pena privada, tese apresentada à Faculdade de Direito da Universidade de São Paulo para inscrição em concurso público visando à obtenção de título de livre docente, São Paulo, 2010.

BORNHEIM, Gerard A., Os filósofos pré-socráticos. Clássicos Cultrix, São Paulo, Editora Cultrix, 1998.

BUNAZAR, Maurício B., Taxonomia da sanção civil: para uma caracterização do objeto da responsabilidade civil, in Revista Juris da Faculdade de Direito, Fundação Armando Alvares Penteado, v. 5, janeiro a junho/2011, São Paulo, FAAP, 2010, p. 39-42.

Responsabilidade civil do incapaz: objetivação da culpa ou responsabilidade civil objetiva?, in Ensaios sobre responsabilidade civil na pós-modernidade, v. 2, coordenadores HIRONAKA, Giselda Maria Fernandes Novaes; SIMÃO, José Fernando, Porto Alegre, Magister, 2009, p. 285-311.

CALIXTO, Marcelo Junqueira, A culpa na responsabilidade civil: estrutura e função, Rio de Janeiro, Renovar, 2008.

CANARIS, Claus Wilhelm, Pensamento sistemático e conceito de sistema na ciência do direito, $4^{\mathrm{a}}$ ed., tradução de António Menezes Cordeiro, Lisboa, Fundação Calouste Gulbenkian, 2008.

CAVALIERI FILHO, Sergio, Programa de responsabilidade civil, $8^{\mathrm{a}}$ ed. revista e ampliada, São Paulo, Atlas, 2008. 
CHAMOUN, Ebert, Instituições de direito romano, $2^{\mathrm{a}}$ ed., Rio de Janeiro, Revista Forense, 1954.

COMPARATO, Fábio Konder; SALOMÃO FILHO, Calixto, O poder de controle na sociedade anônima, $5^{\mathrm{a}}$ ed., Rio de Janeiro, Forense, 2008.

CONSELHO DE ESTADO DA FRANÇA, Responsabilidade e socialização do risco, considerações gerais de relatório público do Conselho de Estado da França, tradução de Michels Abes, Brasília, UniCEUB, 2006.

CORDEIRO, António Menezes, Tratado de direito civil português, v. I - Parte geral, Tomo I-Introdução. Doutrina geral. Negócio jurídico, Coimbra, Almedina, 2010.

. Tratado de direito civil português, v. II - Direito das Obrigações, Tomo III Gestão de negócios, enriquecimento sem causa, responsabilidade civil, Coimbra, Almedina, 2010.

. Da boa-fé no direito civil, $3^{\mathrm{a}}$ reimpressão, Coimbra, Almedina, 2007.

CORREIA, Alexandre, SCIASCIA, Gaetano, Manual de direito romano, v. I, $2^{\mathrm{a}}$ ed., São Paulo, Saraiva, 1953.

COSTA, Mário Júlio de Almeida, Direito das Obrigações, $9^{\mathrm{a}}$ ed. revista e aumentada, Coimbra, Almedina, 2001.

CRUZ, Gisela Sampaio da, O problema do nexo causal na responsabilidade civil, Rio de Janeiro, Renovar, 2005.

DE CUPIS, Adriano, Il Danno - Teoria generale della respnssabilità civile, Milano, Dott. A. Giuffrè Editore, 1946.

DIAS, José de Aguiar, Da responsabilidade civil - Tomo I, $5^{\mathrm{a}}$ ed., Rio de Janeiro, Forense, 1973.

Da responsabilidade civil - Tomo II, $5^{\mathrm{a}}$ ed. revista e aumentada, Rio de Janeiro, Forense, 1973.

DINAMARCO, Cândido Rangel, Instituições de direito processual civil, v. I, $6^{\circ}$ ed., São Paulo, Malheiros, 2009.

FACHIN, Luiz Edson, Responsabilidade civil contemporânea no Brasil: notas para uma aproximação, in Revista Jurídica, n. 397, novembro/2010, p. 11-19. 
FERRAZ JR., Tércio Sampaio, Introdução ao estudo do direito: técnica, decisão e dominação, $4^{\mathrm{a}}$ ed., São Paulo, Atlas, 2003.

FISCHER, Hans Albrecht, A reparação dos danos no Direito Civil, tradução de António de Arruda Ferrer Correia, São Paulo, Livraria Acadêmica - Saraiva \& C ${ }^{a}$ - Editores, 1938.

FRADA, Manuel A. Carneiro da, Direito Civil - Responsabilidade Civil - O método do caso, Coimbra, Almedina, 2006.

FRANÇA, Rubens Limongi, Responsabilidade aquiliana e suas raízes, in Responsabilidade civil - doutrina e jurisprudência, coordenador CAHALI, Yusef Said, São Paulo, Saraiva, 1984, p. 235-255.

Direitos da Personalidade: coordenadas fundamentais, in Revista dos Tribunais, São Paulo, v. 567, janeiro de 1983, p. 09-16.

. Manual de direito civil, v. 1, $4^{\mathrm{a}}$ ed. revista, São Paulo, Revista dos Tribunais, 1980.

GARCÍA DEL CORRAL, D. Ildefonso Luis, Cuerpo del derecho civil romano, Primera Parte - Tomo $1^{o}$ - Instituta-Digesto, Barcelona, Editorial Lex Nova, 1889; e Tomo $3^{o}$ Digesto, Barcelona, Editorial Lex Nova, 1897.

GILISSEN, John, Introdução histórica ao direito, $5^{\mathrm{a}}$ ed., tradução de A. M. Hespanha e L. M. Macaísta Malheiros, Lisboa, Fundação Calouste Gulbenkian, 2008.

GODOY, Cláudio Luiz Bueno de, Responsabilidade civil pelo risco da atividade: uma cláusula geral no Código Civil de 2002, $2^{\mathrm{a}}$ ed., Coleção Professor Agostinho Alvim, coordenação de Renan Lotufo, São Paulo, Saraiva, 2010.

GOMES, Orlando, Obrigações, $8^{\mathrm{a}}$ ed., $4^{\mathrm{a}}$ tiragem, Rio de Janeiro, Forense, 1994.

GONÇALVES, Carlos Roberto, Direito civil brasileiro - responsabilidade civil, v. 4, $5^{\mathrm{a}}$ ed., São Paulo, Saraiva, 2010.

GUARINO, Antonio, Diritto privato romano, $12^{\mathrm{a}}$ ed., Napoli, Editore Jovene Napoli, 2001.

GUEDES, Gisela Sampaio da Cruz, Lucros cessantes - do bom-senso ao postulado normativo da razoabilidade, São Paulo, Editora Revista dos Tribunais, 2011.

GÜNTHER, Klaus, Responsabilização na sociedade civil, in Teoria da responsabilidade no estado democrático de direito: textos de Klaus Günther, organizadoras PÜSCHEL, 
Flávia Portella; MACHADO, Marta Rodriguez de Assis, Série direito em debate. Direito desenvolvimento justiça, São Paulo, Saraiva, 2009.

HENRIOT, Jacques, Note sur la date et le sens de l'apparition du mot "responsabilité,, in Archives de philosophie du droit, n. 22, 1977.

HUME, David, Tratado da natureza humana: uma tentativa de introduzir o método experimental de raciocínio nos assuntos morais, $2^{\mathrm{a}}$ ed. rev. e ampliada, tradução Déborah Danowski, São Paulo, Editora Unesp, 2009.

HUNGRIA, Nelson, Comentários ao Código Penal, v. 1, tomo 2, arts. 11 a 27, $2^{\mathrm{a}}$ ed. revista e atualizada, Rio de Janeiro, Revista Forense, 1953.

JORGE, Fernando de Sandy Lopes Pessoa, Ensaio sobre os pressupostos da responsabilidade civil, Lisboa, Centro de Estudos Fiscais da Direcção-Gerral das Contribuições e impostos - Ministério das Finanças, 1972.

JUSTO, A. Santos, Direito Privado romano II - Direito das obrigações, in Boletim da Faculdade de Direito da Universidade de Coimbra, Coimbra, Coimbra Editora, 2003.

KANT, Immanuel, Crítica da razão pura, $7^{\mathrm{a}}$ ed., tradução de Manuela Pinto dos Santos e Alexandre Fradique Morujão, Lisboa, Fundação Calouste Gulbenkian, 2010.

KASER, Max, Direito privado romano, tradução de Samuel Rodrigues e Ferdinand Hämmerle, revisão de Maria Armanda de Saint-Maurice, Lisboa, Fundação Calouste Gulbekian, 1999.

KELSEN, Hans, Teoria pura do direito, $6^{\mathrm{a}}$ ed., $5^{\mathrm{a}}$ tiragem, tradução João Baptista Machado, São Paulo, Martins Fontes, 1998.

Teoria geral das normas, tradução de José Florentino Duarte, Porto Alegre, Sérgio Fabris, 1986.

. Teoria geral do Direito e do Estado, $4^{\mathrm{a}}$ ed. São Paulo, Martins Fontes, 2005.

KRUEGER, Paulus; MOMMSEN, Theodorus, Corpus Iuris Civilis, volumen primum, 22 ${ }^{\mathrm{a}}$ ed., Berlim, Weidmann, 1973.

LARENZ, Karl, Metodologia da ciência do direito, Lisboa, Fundação Calouste Gulbenkian, 1969.

LEITÃO, Luís Manuel Teles de Menezes, Direito das Obrigações, v. I, $5^{\mathrm{a}}$ ed., Coimbra, Almedina, 2006. 
LEMOS, Patrícia Faga Iglecias, Meio Ambiente e responsabilidade civil do proprietário análise do nexo causal, São Paulo, Revista dos Tribunais, 2008.

LEONEL, Ricardo de Barros, Manual do Processo Coletivo, São Paulo, Revista dos Tribunais, 2002.

LEVY, Daniel de Andrade, Responsabilidade civil: de um direito dos danos a um direito das condutas lesivas, São Paulo, Atlas, 2012.

LIMA, Alvino, Culpa e risco, São Paulo, Revista dos Tribunais, 1960.

LOPEZ, Teresa Ancona, Princípio da precaução e evolução da responsabilidade civil, São Paulo, Quartier Latin, 2010.

LUHMANN, Niklas, Sociologia do direito I, tradução de Gustavo Bayer, Rio de Janeiro, Edições Tempo Brasileiro, 1983.

A improbabilidade da comunicação, $4^{\mathrm{a}}$ ed., tradução de Anabela Carvalho, Lisboa, Vega - Passagem, 2006.

. A realidade dos meios de comunicação, tradução de Ciro Marcondes Filho, São Paulo, Paulus, 2005.

Introdução à teoria dos sistemas, aulas publicadas por Javier Torres Nafarrate, tradução de Ana Cristina Arantes Nasser, Petrópolis, Editora Vozes, 2009.

LUMIA, Giuseppe, Elementos de teoria e ideologia do direito, tradução de Denise Agostinetti, São Paulo, Martins Fontes, 2003.

MADEIRA, Hélcio Maciel França, adaptação para fins acadêmicos de excertos extraídos da obra Ensaios de Philosophia do Direito de José Mendes.

MARKY, Thomas, Curso elementar de direito romano, $8^{\mathrm{a}}$ ed., São Paulo, Saraiva, 1995.

MARTINS-COSTA, Judith, Comentário ao novo Código Civil, vol. V, tomo II: do inadimplemento das obrigações, arts. 389 a 420, coordenador TEIXEIRA, Sálvio de Figueiredo, Rio de Janeiro, Forense, 2004.

MARTON, G., Les fondements de la responsabilité civile - Révision de la doctrine - Essai d'un système unitaire, Paris, Librairie du Recueil Sirey, 1938.

MAZEUAD, Henri; MAZEAUD, Léon; TUNC, André, Tratado teórico y práctico de la responsabilidad civil delictual y contractual, tomo I, v. I, Buenos Aires, Ediciones Jurídicas Europa-América, 1961. 
MEIRA, Silvio Augusto de Bastos, Instituições de Direito Romano, $3^{\text {a }}$ ed., São Paulo, Max Limonad, 1968.

MELlO, Marcos Bernardes de, Teoria do fato jurídico - Plano da existência, $14^{\mathrm{a}}$ ed. revista, São Paulo, Saraiva, 2007.

MILARÉ, Édis, Direito do ambiente: a gestão ambiental em foco: doutrina, jurisprudência, glossário, $6^{a}$ ed. rev., atual. e ampl., São Paulo, Revista dos Tribunais, 2009.

MIOTTO, Armida Bergamini, Sanção penal - I, in Enciclopédia Saraiva do Direito, v. 67, coordenação de FRANÇA, Rubens Limongi, São Paulo, Saraiva, 1977.

MONTEIRO, Washington de Barros; MALUF, Carlos Alberto Dabus, Curso de direito civil - Direito das obrigações - $1^{a}$ parte, v. 4, 35 a ed., São Paulo, Saraiva, 2010.

MORSELLO, Marco Fábio, Responsabilidade civil no transporte aéreo, São Paulo, Atlas, 2006.

NORONHA, Fernando, Direito das obrigações - fundamentos do direito das obrigações introdução à responsabilidade civil, v. 1, 2ª ed. rev. e atual., São Paulo, Saraiva, 2007.

PEREIRA, Caio Mário da Silva, Instituições de direito civil - Teoria geral das obrigações, v. II, $21^{\text {a }}$ ed., Rio de Janeiro, Forense, 2007.

PETIT, Eugène, Tratado elementar de direito romano, tradução de Jorge Luis Custódio Porto, Campinas, Russel, 2003.

PONTES DE MIRANDA, Francisco Cavalcanti, Tratado de Direito Privado - Parte Geral - Tomo I - Introdução. Pessoas físicas e jurídicas, $3^{\mathrm{a}}$ ed., Rio de Janeiro, Borsoi, 1970.

Tratado de Direito Privado - Parte Geral - Tomo II - Bens. Fatos Jurídicos, $3^{\mathrm{a}}$ ed., Rio de Janeiro, Borsoi, 1970.

. Tratado de Direito Privado - Parte Especial - Tomo LIII - Direito das Obrigações: Fatos ilícitos absolutos. Atos-fatos ilícitos absolutos. Atos ilícitos absolutos. Responsabilidade. Danos causados por animais. Coisas inanimadas e danos. Estado e servidores. Profissionais, $3^{\mathrm{a}}$ ed., reimpressão, Rio de Janeiro, Borsoi, 1972. 
POPPER, Karl R., O mito do contexto: em defesa da ciência e da racionalidade, tradução de Paula Taipas, Coleção Biblioteca de Filosofia Contemporânea, Lisboa, Edições 70, 2009.

- A lógica e a evolução da teoria científica, in A vida é aprendizagem. Epistemologia evolutiva e sociedade aberta, tradução de Paula Taipas, Coleção Biblioteca de Filosofia Contemporânea, Lisboa, Edições 70, 1999.

PRADO, Luiz Regis, Curso de Direito Penal Brasileiro - Parte Geral - arts. $1^{\circ}$ a 120, v. 1, $5^{\text {a }}$ ed. revista, São Paulo, Editora Revista dos Tribunais, 2005.

PÜSCHEL, Flávia Portella; MACHADO, Marta Rodriguez de Assis, Questões atuais acerca da relação entre as responsabilidades penal $e$ civil, in http://www.gv.br/biblioteca/pe/SP000503359.pdf. Acesso em janeiro de 2011.

REALE, Miguel, Fundamentos do direito, $2^{\mathrm{a}}$ ed., São Paulo, Revista dos Tribunais, 1972. . Teoria tridimensional do direito: preliminares históricas e sistemáticas, $3^{\mathrm{a}}$ ed. revista e atualizada, São Paulo, Saraiva, 1980.

. Verdade e Conjetura, Rio de Janeiro, Editora Nova Fronteira, 1983.

. Fontes e modelos do direito: para um novo paradigma hermenêutico, São Paulo, Saraiva, 1994.

O Direito como experiência: introdução à epistemologia jurídica, $2^{\mathrm{a}}$ ed., $4^{\mathrm{a}}$ tiragem, São Paulo, Saraiva, 2010;

REALE JÚNIOR, Miguel, Parte geral do Código Penal (nova interpretação), São Paulo, Editora Revista dos Tribunais, 1988.

RODRIGUES, Silvio, Direito Civil - Parte geral das obrigações, v. 2, 30ª ed., São Paulo, Saraiva, 2002. Responsabilidade civil, v. 4, 20ª ed., São Paulo, Saraiva, 2003.

ROMANI, Giovanni, Dizionario Generale de'Sinonimi Italiani, v. 1, Milano, Giovanni Silvestri, 1725.

ROSS, Alf, Logica de las normas, traducción por Jose S.P. Hierro, Madrid, Editorial Tecnos, 1971.

ROXIN, Claus, Derecho penal - Parte general - Tomo I - Fundamentos. La estructura de la teoria del delito, traducción de la $2^{\text {a }}$ edición alemana y notas por Diego-Manuel Luzón 
Peña, Miguel Díaz y García Conlledo e Javier de Vicente Remesal, Madrid, Editorial Civitas, 2001.

SANSEVERINO, Paulo de Tarso Vieira, Princípio da reparação integral - indenização no Código Civil, São Paulo, Saraiva, 2010.

SARTRE, Jean-Paul, O existencialismo é um humanismo, tradução de João Batista Kreuch, Petrópolis, Vozes, 2010.

SAVI, Sérgio, Responsabilidade civil por perda de uma chance, São Paulo, Atlas, 2006.

SAVIGNY, Friedrich Karl von, Sistema del diritto romano attuale, volume primo, traduzione dall'originale tedesco di Vittorio Scialoja, Torino, Unione Tipografico Editrice, 1886.

SCHREIBER, Anderson, Novos paradigmas da responsabilidade civil: da erosão dos filtros da reparação à diluição dos danos, $2^{\mathrm{a}}$ ed., São Paulo, Atlas, 2009.

SHAKESPEARE, William, Romeo and Juliet, Leipzig, B. G. Teubner, 1859.

SILVA, Rafael Peteffi da, Responsabilidade civil pela perda de uma chance: uma análise do direito comparado e brasileiro, São Paulo, Atlas, 2007.

SILVA, Virgílio Afonso da, A constitucionalização do direito. Os direitos fundamentais nas relações particulares, $1^{\mathrm{a}}$ ed., $2^{\mathrm{a}}$ tiragem, São Paulo, Malheiros, 2005.

SIMÃO, José Fernando, Responsabilidade civil do incapaz, São Paulo, Atlas, 2008.

A teoria dualista do vínculo obrigacional e sua aplicação ao direito civil brasileiro, in Direito das obrigações: reflexões no direito material e processual: obra em homenagem a Jones Figueirêdo Alves, coordenadores DE PAULA, Fernanda Pessoa Chuahy; MENEZES, Iure Pedroza; CAMPELLO, Nalva Cristina Barbosa, São Paulo, Método, 2011, p. 239-253.

SZTAJN, Raquel, Teoria jurídica da empresa: atividade empresária e mercados, São Paulo, Atlas, 2004.

TELLES, Inocêncio Galvão, Direito das obrigações, $7^{\mathrm{a}}$ ed. revista e actualizada, Coimbra, Coimbra Editora, 1997.

TELLES JUNIOR, Goffredo, Direito Quântico: ensaio sobre o fundamento da ordem jurídica, $8^{\text {a }}$ ed. revista, São Paulo, Editora Juarez de Oliveira, 2006. 
TEUBNER, Gunther, $O$ direito como sistema autopoiético, tradução e prefácio de José Engrácia Antunes, Lisboa, Fundação Calouste Gulbenkian, 1989.

THON, August, Norma giuridica e diritto soggettivo: indagini di teoria generale del diritto: indagini di teoria generale del diretto, seconda edizione, prima traduzione del Prof. Alessandro Levi, Padova, CEDAM, 1951.

TUCCI, Giuseppe, Il danno ingiusto, Napoli, Editore Jovene Napoli, 1970.

VARELA, João de Matos Antunes, Das obrigações em geral, v. I, 10 a ed. revista e actualizada, Coimbra, Almedina, 2008.

VILANOVA, Lourival, As estruturas lógicas e o sistema de direito positivo, São Paulo, Revista dos Tribunais, 1997.

Causalidade e relação no direito, $4^{\mathrm{a}}$ ed. revista, atualizada e ampliada, São Paulo, Editora Revista dos Tribunais, 2000.

VILLAS BÔAS FILHO, Orlando, Teoria dos sistemas e o direito brasileiro, São Paulo, Saraiva, 2009.

VINEY, Geneviève, As tendências atuais do direito da responsabilidade civil, tradução de Paulo Cezar de Mello, in Direito Civil Contemporâneo: novos problemas à luz da legalidade constitucional: anais do Congresso Internacional de Direito CivilConstitucional da cidade do Rio de Janeiro, organizador TEPEDINO, Gustavo, São Paulo, Atlas, 2008, p. 42-56.

VOGEL, Carlos Alfredo, Historia del derecho romano - desde sus origenes hasta la epoca contemporanea, $3^{\mathrm{a}}$ ed., Buenos Aires, Editorial Perrot, 1957.

VOLTERRA, Eduardo, Instituciones de Derecho Privado Romano, traducción, prólogo y notas a la edición española de Jesús Daza Martínez, reimpresión da $1^{\text {a }}$ edición, Madrid, Editorial Civitas S.A., 1991.

WALD, Arnold, Direito Civil - Direito das obrigações e teoria geral dos contratos, $19^{\mathrm{a}}$ ed., São Paulo, Saraiva, 2010. 